\title{
The role of private actors in the provision of public goods with applications to infrastructure and financial stability : acounting and financial approaches to assess macroeconomic perspectives
}

Citation for published version (APA):

Sfakianakis, E. (2011). The role of private actors in the provision of public goods with applications to infrastructure and financial stability : acounting and financial approaches to assess macroeconomic perspectives. [Doctoral Thesis, Maastricht University]. Boekenplan.

https://doi.org/10.26481/dis.20110525es

Document status and date:

Published: 01/01/2011

DOI:

$10.26481 /$ dis.20110525es

Document Version:

Publisher's PDF, also known as Version of record

Please check the document version of this publication:

- A submitted manuscript is the version of the article upon submission and before peer-review. There can be important differences between the submitted version and the official published version of record. People interested in the research are advised to contact the author for the final version of the publication, or visit the DOI to the publisher's website.

- The final author version and the galley proof are versions of the publication after peer review.

- The final published version features the final layout of the paper including the volume, issue and page numbers.

Link to publication

\footnotetext{
General rights rights.

- You may freely distribute the URL identifying the publication in the public portal. please follow below link for the End User Agreement:

www.umlib.nl/taverne-license

Take down policy

If you believe that this document breaches copyright please contact us at:

repository@maastrichtuniversity.nl

providing details and we will investigate your claim.
}

Copyright and moral rights for the publications made accessible in the public portal are retained by the authors and/or other copyright owners and it is a condition of accessing publications that users recognise and abide by the legal requirements associated with these

- Users may download and print one copy of any publication from the public portal for the purpose of private study or research.

- You may not further distribute the material or use it for any profit-making activity or commercial gain

If the publication is distributed under the terms of Article 25fa of the Dutch Copyright Act, indicated by the "Taverne" license above,

Download date: 26 Apr. 2023 


\title{
The role of private actors in the provision of public goods with applications to infrastructure and financial stability
}

\author{
Accounting and financial \\ approaches to assess \\ macroeconomic perspectives
}

\author{
DISSERTATION \\ to obtain the degree of Doctor \\ at the Maastricht University, \\ on the authority of the Rector Magnificus \\ Prof. dr. G.P.M.F. Mols \\ in accordance with decision of the Board of Deans, \\ to be defended in public \\ on Wednesday 25 May 2011, at 14:00 hrs \\ by Emmanouil Sfakianakis
}


(C) 2011 Emmanouil Sfakianakis

All rights reserved. No part of this publication may be reproduced, stored in a retrieval system, or transmitted in any form, or by any means, electronic, mechanical, photocopying, recording or otherwise, without the prior permission in writing, from the author.

ISBN: 9789086662050

Published by Boekenplan, Maastricht 
Primary Promoter: Prof. Dr. Bertrand Candelon, Professor in International Monetary Economics, Maastricht University, School of Business and Economics.

Secondary Promoter: Dr. Jaap Bos, Associate Professor of Finance, Maastricht University, School of Business and Economics.

Co-Promoter: Dr. Mindel van de Laar, PhD Director, Senior Programme Manager Training Activities and Research Projects, University of Maastricht, Maastricht Graduate School of Governance.

Assessment Committee:

Prof. Dr. Adam Szirmai, Professor in Governance, Policy Analysis and Development Economics, University of Maastricht, Maastricht Graduate School of Governance, UNU Merit.

Prof. Dr. Pierre Mohnen, Professor of the Microeconometrics of Technical Change, University of Maastricht, School of Business and Economics, UNU-MERIT.

Prof. Dr. Olaf Sleijpen, Professor of European Economic Policy, University of Maastricht, School of Business and Economics.

Dr. Stefan Straetmans, Associate Professor of Finance, University of Maastricht, School of Business and Economics.

Prof. Dr. Brigitte Unger, Professor of Public Sector Economics, Utrecht University, School of Economics (USE). 


\section{Acknowledgments}

"As you set out for distant Ithaca, hope the voyage is a long one, full of adventure, full of discovery." My journey towards the completion of a $\mathrm{PhD}$ degree together with professional duties was beyond any doubt a challenging but also wonderful adventure. Even though I had to face numerous "Laestrygones and Cyclopes," this journey had a happy ending which I would not reach if it was not for the precious support, guidance and love of many people. To all of you, I owe gratitude.

"You'll never find things like that on your way as long as you keep your thoughts raised high, as long as a rare excitement stirs your spirit." I could not keep my thoughts and spirit up without the precious guidance of my supervisors. Jaap (Bos), I was motivated by and admired your critical suggestions, analytical thinking and constructive contributions. Your valuable assistance showed me the way and helped me overcome many obstacles. I am not sure if "writing a $\mathrm{PhD}$ thesis is like a water polo game," but I would sure drown without your efficient supervision. Bertrand (Candelon), I was stimulated by your fresh ideas and your novel outlook of the subjects in the thesis. I would not realize one of the most integral parts of it without your inspiration: the viewpoint of government crisis interventions as PPPs. For this, for the enlightening discussions we had on the Greek debt crisis in your office whenever I was in Maastricht and for all your mentorship and support, I am grateful. I also feel thankful towards the members of my assessment committee: Prof. Dr. Adam Szirmai, Prof. Dr. Pierre Mohnen, Prof. Dr. Olaf Sleijpen, Dr. Stefan Straetmans and Prof. Dr. Brigitte Unger. Your comments were extremely helpful to improve and integrate the manuscript in specific critical areas.

"Fervently wish your journey is a long one. May there be numerous - the summer mornings when, with what pleasure, what joy, you will be anchoring in harbors you have never seen before." Mindel (van de Laar), I thank you for your 
comments and advice which helped with editing and improving this thesis in terms of quality and clarity and for the encouragement during the first steps. But you (together with other staff of the School), achieved a much more important thing: you taught me how to do research. Thus, I would like to express special thanks to you and Chris (de Neubourg) as representatives of the School who gave me the opportunity to complete a $\mathrm{PhD}$ in a well-organized and flexible organization. I could not imagine better conditions for a researcher to realize his goals. I have been exceptionally privileged to have such dedicated supervisors, inspiring mentors and prominent research environment. You all made me realize that the long voyage was worthwhile in order to finally reach many rewarding summer mornings.

"But hurry not the voyage in the least. Twere better if you travelled many years, and reached your island home in your old age, being rich in riches gathered on the way." I feel that I ended up wealthier finishing this journey. Except from knowledge and experience, I have gained some new good friends. Sepideh, Laura and Dennis I feel grateful for the support, encouragement and motivation you provided me with. I hope that your pathway is as rewarding and fruitful as mine was.

"Ithaca gave you the delightful voyage. Without her you would not have set out ... Wise as you will have become, so full of experience, you will have understood by then what these Ithacas mean." I did become wiser through my $\mathrm{PhD}$ journey. However, I would not reach my Ithaca without the support and love of my beloved ones. Also, I am sure that there will be more Ithacas to reach with them by my side. A new journey starts soon with my love and co-traveler in the journey of life, Maria. I couldn't have fulfilled this goal without your love, compassion and most importantly belief in me. I know that there will be other exciting "Phoenician trading stations to buy fine things" and "many Egyptian cities to gather stores of knowledge" for us to discover. My brother 
Yianni, you have been so constructive with your critical viewpoint on my quantitative analysis. I am sure that, in the end, it was not adequate for your standards, but this critique integrated my research. For this, but also for always being there for me, I thank you. A special tribute to my dearly loved cousin George, who recently left us and will always be remembered as the beautiful person he was. I also need to thank my grandmother, Irene. Even if he does not exactly know what a $\mathrm{PhD}$ is, she can distinguish the importance and magnitude of the effort. Grandma, you were always supportive and you gave to us all so much unselfish love. For this, I will always been indebted to you.

Finally, Mom, you taught and keep teaching me life. I dedicate this book to you.

Quotes from C.P. Cavafy's "Ithaca” 


\section{Table of Contents}

ACKNOWLEDGMENTS.......................................................................IV

TABLE OF CONTENTS ........................................................................... VII

LIST OF FIGURES.....................................................................................XI

LIST OF TABLES.................................................................................XIII

LIST OF BOXES ...................................................................................XVI

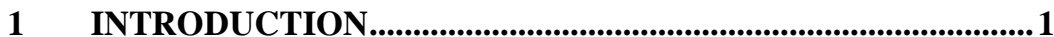

1.1 PUBLIC-PRIVATE PARTNERSHIPS IN PUBLIC POLICYMAKING ...... 1

1.2 MAIN RESEARCH QUESTIONS .................................................. 4

1.3 PUBLIC-PRIVATE PARTNERSHIPS AND CRISIS REMEDIES: THE

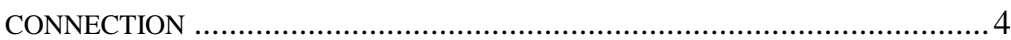

1.3.1 Budget affordability and value for money ........................... 6

1.3.2 The public risk exposure and the inelasticity of social demand .................................................................................... 7

1.3.3 Public-private partnership guarantees and asset and liability crisis management ............................................................ 9

1.4 CONTRIBUTION ........................................................... 11

1.4.1 Evaluating government contingencies in public-private partnerships ............................................................................... 11

1.4.2 Assessing government decisions and commitments as focused interventions .................................................................. 12

2 PUBLIC-PRIVATE PARTNERSHIPS, THE GOVERNMENT BUDGET AND RISK IMPLICATIONS....................................................15

2.1 INTRODUCTION................................................................. 15

2.2 LITERATURE LINKAGES ........................................................ 15

2.2.1 The IMF on fiscal risk and government guarantees ......... 15

2.2.2 Macroeconomic and accounting viewpoints..................... 17

2.2.3 Contract theory, syndicated lending and the public-private partnership link ......................................................................... 19

$2.3 \quad$ PUBLIC-PRIVATE PARTNERSHIPS .............................................. 20

2.3.1 Public-private partnership definitions ............................... 20

2.3.2 Public-private partnership schemes ................................. 23

2.4 PUBLIC-PRIVATE PARTNERSHIPS AND THE GOVERNMENT BUDGET …............................................................................. 25

2.4.1 Typical public investment versus a public-private

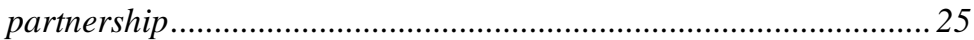

2.4.2 Implications for fiscal sustainability and government balance effects........................................................................... 26

$2.5 \quad$ RISK ALLOCATION ............................................................. 28

2.5.1 Risk management implications ......................................... 28

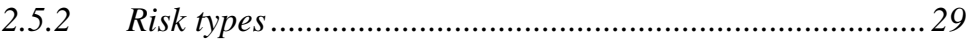


2.5.3 Allocating private and public sector risk........................... 30

2.5.4 Risk transfer analysis.................................................... 32

2.5.5 Demand risk, competition and externalities .......................33

2.6 GOVERNMENT GUARANTEES AS CONTINGENT LIABILITIES .......36

3 VALUING PUBLIC-PRIVATE PARTNERSHIP RISK: A SCENARIO ANALYSIS.....................................................................39

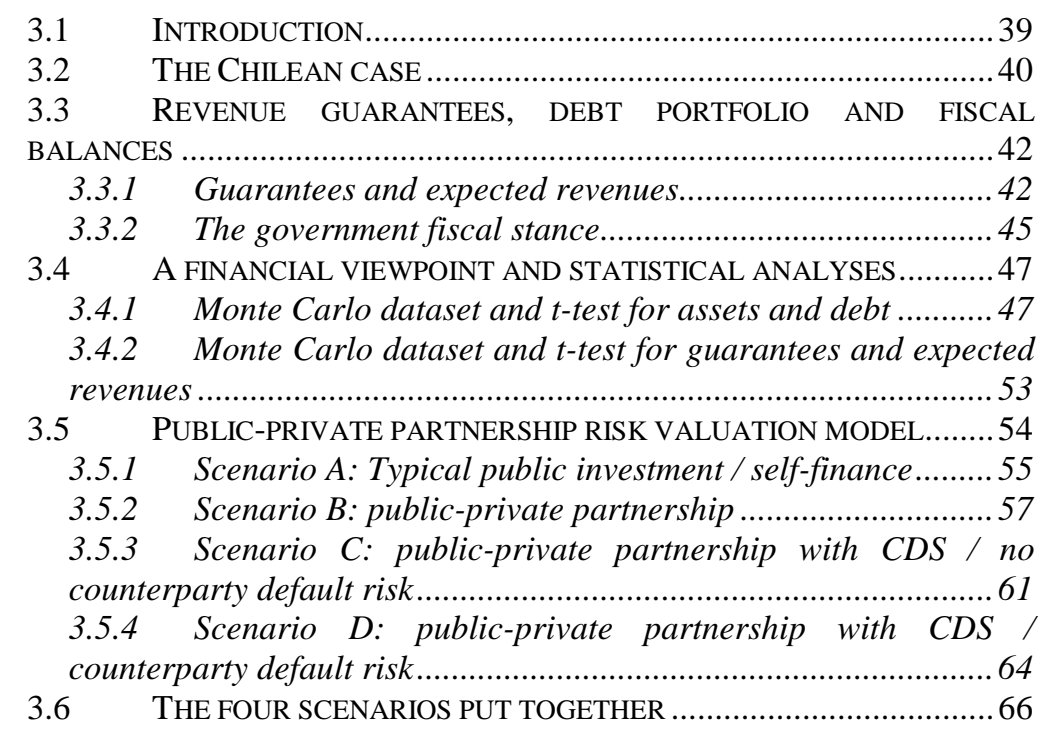

4 THE CREDIT CRISIS. PRIVATE PARTNERSHIPS FOR

PUBLIC REMEDIES........................................................................69

4.1 CREDIT CRISIS AND BANKING SECTOR INTERVENTIONS: AN

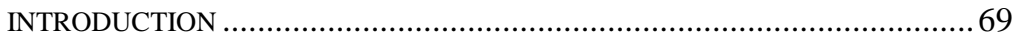

4.2 THE CHRONICLES OF THE CREDIT CRISIS ................................. 71

4.2.1 Reasons and roots........................................................... 71

4.2.2 Government responses................................................... 72

4.3 LESSONS FROM PREVIOUS CRISIS EPISODES .......................... 73

4.4 INTERVENTIONS IN THE CURRENT CRISIS ................................. 76

4.5 CATEGORIZING THE INTERVENTIONS...................................... 77

4.5.1 Asset management ............................................................ 77

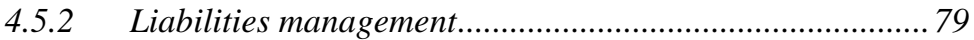

4.5.3 Equity management ............................................................ 80

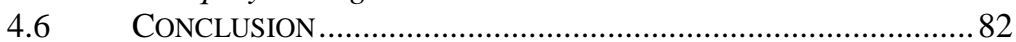

5 CRISIS BALANCE SHEET ANALYSIS AND FISCAL

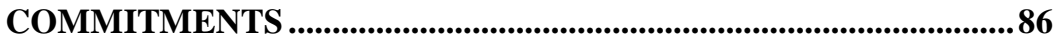

5.1 INTRODUCING THE BALANCE SHEET APPROACH .....................86

5.2 THE BALANCE SHEET EFFECT ................................................ 87

5.2.1 The balance sheet and the bank's performance ................ 87 


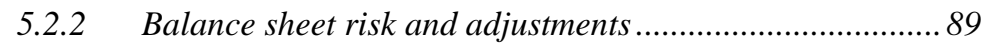

5.2.3 The effect of one intervention.............................................. 90

5.2.4 The effect of an intervention mix...................................... 97

5.3 OFF-BALANCE SHEET EXPOSURES, ASSET VALUATION AND

MACROECONOMIC SHOCKS ................................................................ 101

5.3.1 Option pricing theory and guarantees valuation............. 101

5.3.2 The off-balance nature of banks ..................................... 103

5.3.3 Asset valuation and guarantees exposure ........................ 104

5.4 THE G20 RESPONSE, SUPPORT COSTS AND THE FISCAL

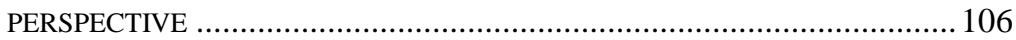

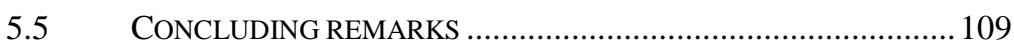

6 ASSESSING GOVERNMENT CRISIS INTERVENTIONS... 111

6.1 INTRODUCING THE INTERVENTION DECISION PROCESS ..........111

6.1.1 The link with the balance sheet approach........................ 111

6.1.2 Three steps to unlock the government course of action ... 111

6.2 THE LOGIT MODEL AND THE DATASET .................................. 113

6.2.1 The logit model and jackknife ....................................... 113

6.2.2 The variables and the data ................................................ 114

6.2.3 The ordered logit model.................................................. 118

6.3 THE ECONOMIC RATIONALE BEHIND THE VARIABLE

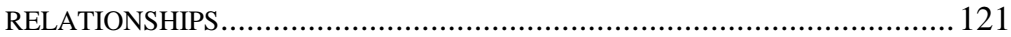

6.3.1 Asset management variables.......................................... 121

6.3.2 Liabilities management variables................................... 123

6.3.3 Equity management variables........................................ 125

6.4 THE STEPS IN THE PROCESS AND THE RESULTS ..................... 128

6.4.1 Step 1: Unconditional and conditional probabilities of one intervention .............................................................................. 128

6.4.2 Step 2: Unconditional and conditional probabilities of two

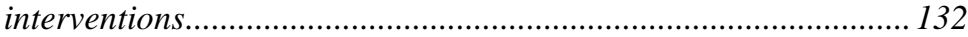

6.4.3 Step 3: Unconditional and conditional probabilities of three interventions................................................................................ 136

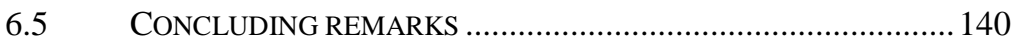

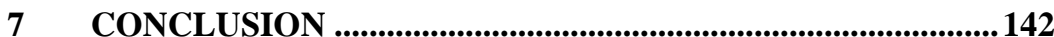

7.1 USING PRIVATE METHODS TO ASSESS PUBLIC PROJECT RISK IN

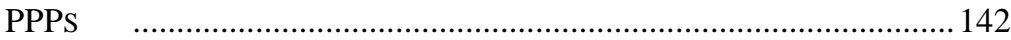

7.2 THE EX ANTE DETERMINANTS AND THE EX POST EFFECTS OF GOVERNMENT CRISIS INTERVENTIONS .............................................. 143

7.3 PUBLIC COMMITMENTS AND POLICY LESSONS ....................... 146

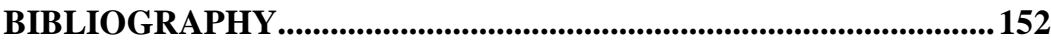

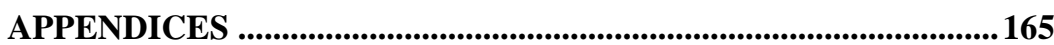

APPENDIX 3-A: NOMINAL AND DISCOUNTED VALUES OF GUARANTEES, EXPECTED REVENUES AND NET CONTINGENT FLOWS 165 
APPENDIX 3-B: GOVERNMENT DEFICIT/SURPLUS AND GDP / GROSS DEBT, TYPICAL PUBLIC INVESTMENT VS. PUBLIC-PRIVATE PARTNERSHIP....... 167 APPENDIX 3-C: NORMALITY TESTS ..................................................... 170 APPENDIX 3-D: MONTE CARLO SIMULATION RESULTS ........................ 172 APPENDIX 3-E: STANDARD \& POOR'S ONE-YEAR GLOBAL CORPORATE DEFAULT RATES BY REFINED RATING CATEGORY, 1981-2008.............. 176 APPENDIX 3-F: CREDIT DEFAUlT SWAP (CDS) DEFINITIONS AND

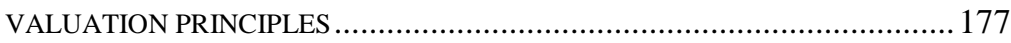
APPENDIX 3-G: DETAILED CALCULATIONS OF EXPECTED CDS PAYMENTS, CDS ACCRUALS AND CDS PAYOFFS .............................. 185 APPENDIX 4-A: CREDIT PROTECTION AND SECURITIZED TRANSACTIONS

4-A.1 Cross-country and market spillovers.................................. 189

4-A.2 Beyond banks ................................................................ 190

4-A.3 Asset-backed securities ....................................................... 191

4-A.4 Complexity of off-balance sheet operations ......................... 193

APPENDIX 5-A: THE MANAGEMENT OF GOVERNMENT GUARANTEES... 195 APPENDIX 6-A: COMPLETE SET OF INTERVENTION VARIABLES FOR

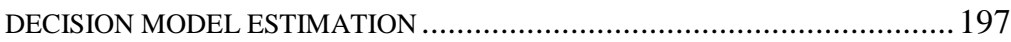
APPENDIX 6-B: COMPLETE DATASET OF INTERVENTION VARIABLES FOR

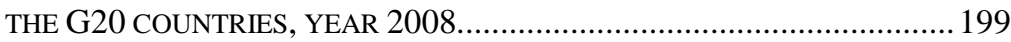
APPENDIX 6-C: ADDITIONAL DATASET OF INTERVENTION VARIABLES FOR THE G20 COUNTRIES, YEAR 2007..................................................... 205 APPENDIX 6-D: ADDITIONAL TABLES FOR SIMPLE LOGIT REGRESSION RESULTS AND THE LOG ODDS FOR SIGNIFICANT VARIABLES................207

NEDERLANDSE SAMENVATTING ..............................................209

CURRICULUM VITAE ..................................................................2213

MAASTRICHT GRADUATE SCHOOL OF GOVERNANCE DISSERTATION SERIES.........................................................................214 


\section{List of Figures}

FIGURE 2.1: A DEFINITION FOR PUBLIC-PRIVATE PARTNERSHIPS............... 22

FIGURE 2.2: ForMS OF PUBLIC-PRIVATE PARTNERSHIPS ........................... 24

FIGURE 3.1: A GOVERNMENT BOND AS AN OPTION FOR THE EQUITY HOLDER (INVESTOR) AND THE DEBT HOLDER (GOVERNMENT) .......................53

FIGURE 3.2: POSITIVE AND NEGATIVE EFFECTS IN PUBLIC ACCOUNTS FOR SCENARIO A: TYPICAL PUBLIC INVESTMENT / SELF FINANCE ...........55

Figure 3.3: Positive AND NEGATIVE EFFECTS IN PUBLIC ACCOUNTS FOR SCENARIO B: PUBLIC-PRIVATE PARTNERSHIP (PPP) .........................58

FIGURE 3.4: POSITIVE AND NEGATIVE EFFECTS IN PUBLIC ACCOUNTS FOR SCENARIOS C AND D: PUBLIC-PRIVATE PARTNERSHIP WITH CREDIT

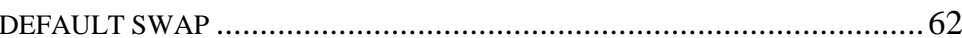

FIGURE 3.5: SCENARIO-BASED MODEL FOR PPP RISK VALUATION .............. 68

FIGURE 4.1: GROUPS OF INTERVENTIONS, ASSET MANAGEMENT AND

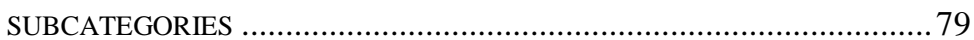

FigURE 4.2: GROUPS OF INTERVENTIONS, LIABILITIES MANAGEMENT AND

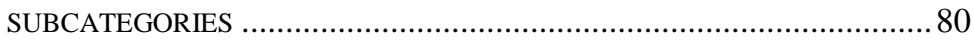

FIGURE 4.3: GROUPS OF INTERVENTIONS, EQUITY MANAGEMENT AND

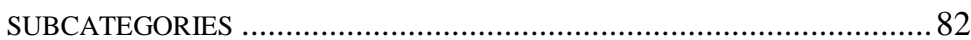

FIGURE 5.1: A SIMPLIFIED BANK BALANCE SHEET …….............................. 88

FIGURE 5.2: TWO SECTORAL BALANCE SHEETS: THE GOVERNMENT AND THE BANK

FIGURE 5.3: ASSET MANAGEMENT BALANCE SHEET EFFECT, PURCHASE OF DISTRESSED ASSETS ................................................................ 92

FIGURE 5.4: LIABILITIES MANAGEMENT BALANCE SHEET EFFECT, GUARANTEE PROVISION (EXTENDED BALANCE SHEET) ...................93

FIGURE 5.5: EQUITY MANAGEMENT BALANCE SHEET EFFECT, DIRECT

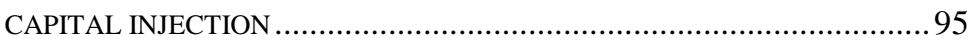

FIGURE 5.6: BALANCE SHEET EFFECT: A COMBINATION OF A PURCHASE OF DISTRESSED ASSETS AND A GUARANTEE PROVISION (EXTENDED BALANCE SHEET) .98

FIGURE 5.7: BALANCE SHEET EFFECT: A COMBINATION OF A GUARANTEE PROVISION AND A DIRECT CAPITAL INJECTION (EXTENDED BALANCE SHEET) 98

FIGURE 5.8: BALANCE SHEET EFFECT: A COMBINATION OF A PURCHASE OF DISTRESSED ASSETS, A GUARANTEE PROVISION AND A DIRECT CAPITAL INJECTION (EXTENDED BALANCE SHEET)

FIGURE 5.9: BALANCE SHEET EFFECT: A COMBINATION OF A PURCHASE OF DISTRESSED ASSETS AND A DIRECT CAPITAL INJECTION ….................99

FIGURE 5.10: BANK END-PERIOD BALANCE SHEET .................................... 105

FIGURE 5.11: BANK BALANCE SHEET INCLUDING MACROECONOMIC SHOCKS

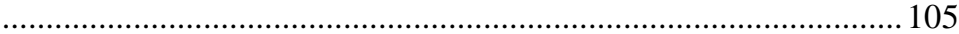

FIGURE 6.1: GOVERNMENT INTERVENTION DECISION CHART ................... 112

FIGURE 6.2: PROBABILITIES AND CONFIDENCE INTERVALS FOR SIGNIFICANT VARIABLES (ONE INTERVENTION) 
FiguRE 6.3: PROBABILITIES AND CONFIDENCE INTERVALS FOR RELATED VARIABLES (ONE INTERVENTION)

FIGURE 6.4: PROBABILITIES AND CONFIDENCE INTERVALS FOR A MIX OF TWO INTERVENTIONS (EXPLANATORY VARIABLES MEASURED CONTINUOUSLY)

FIGURE 6.5: PROBABILITIES AND CONFIDENCE INTERVALS FOR A MIX OF THREE INTERVENTIONS (EXPLANATORY VARIABLES MEASURED CONTINUOUSLY)

FIGURE 6.6: SUMMARY OF RESULTS FOR GOVERNMENT INTERVENTION DECISIONS 140

APPENDIX 3-D / FIGURE 1: MONTE CARLO SIMULATION RESUlTS CONSOLIDATED ASSETS 172

APPENDiX 3-D / Figure 2: Monte CARlo Simulation RESUlts CONSOLIDATED DEBT. 173 APPENDIX 3-D / Figure 3: MONTE CARLO SIMUlation RESUlts -

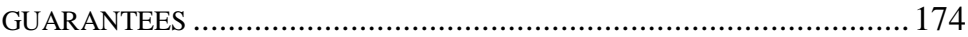

APPENDIX 3-D / Figure 4: MONTE CARlo SIMUlation RESUlts EXPECTED REVENUES 175

APPENDIX 4-A / FIGURE 1: THIRD LEVEL SECURITIZATION FROM SUBPRIME MORTGAGE LOANS

APPENDIX 6-D / FIGURE 1: LOG ODDS FOR SIGNIFICANT VARIABLES........ 208 


\section{List of Tables}

TABLE 3.1: RoUTE 5 PROJECTS DATA ....................................................... 41

TABLE 3.2: GUARANTEES, EXPECTED REVENUES AND NET CONTINGENT FLOWS PER SECTION FOR ROUTE 5 PROJECTS, DISCOUNTED VALUES IN

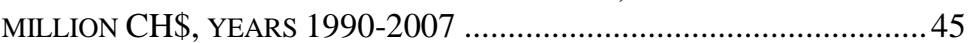

TABLE 3.3: CHILEAN GOVERNMENT DEFICIT / SURPLUS DEFICIT AND TOTAL NET CONTINGENT FLOWS, MILLION CH\$, YEARS 1990-2007 ...............46

TABLE 3.4: CHILEAN GOVERNMENT CONSOLIDATED ASSETS AND GROSS DEBT INCLUDING NET CONTINGENT FLOWS FROM PPP GUARANTEES, NOMINAL VALUES IN MILLION CH\$, YEARS 1990-2007 .....................48

TABLE 3.5: CHILEAN GOVERNMENT DEFICIT/SURPLUS, INVESTMENT COST, PROJECT REVENUES, MILLION CH\$, YEARS 1990-2007 .......................56

TABle 3.6: ChILEAN GOVERNMENT DEFICIT/SURPLUS, TYPICAL PUBliC InVESTMENT vs. PUblic-Private Partnership, Million CH\$, YEARS 1990-2007

TABLE 3.7: EXPECTED CDS PAYMENTS, ACCRUALS AND PAYOFFS, DISCOUNTED VALUES, ROUTE 5 PROJECTS …………………….......... 63

TABLE 3.8: EXPECTED CDS PAYMENTS INCLUDING COUNTERPARTY

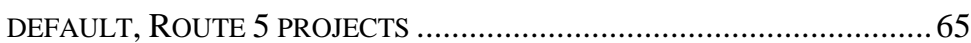

TABLE 4.1: CRISIS POLICIES OF 42 BANKING CRISES EPISODES, 1970-2007 75

TABLE 4.2: OVERVIEW OF POLICY MEASURES, G20, SPAIN AND

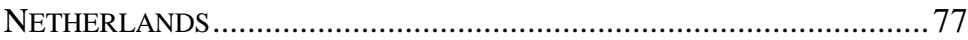

TABLE 4.3: AIMS AND RISKS OF REMEDIES FOR THE GOVERNMENT ..............85

TABLE 5.1: DOMINANT INTERVENTIONS AND THE EFFECT ON BALANCE

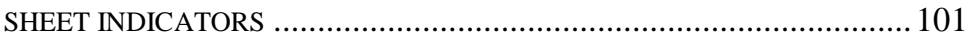

TABLE 5.2: FINANCIAL SUPPORT OPERATIONS AND THE IMPACT ON THE

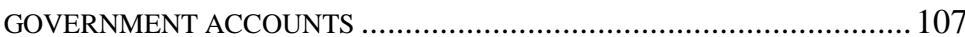

TABLE 5.3: CHANGE IN FISCAL BALANCES AND PUBLIC DEBT IN THE G20 (\% OF GDP, DIFFERENCE WITH RESPECT TO PREVIOUS PERIOD) ............ 108

TABLE 6.1: INTERVENTION DECISIONS IN THE BANKING SECTOR, G20, SPAIN AND NETHERLANDS

TABLE 6.2: FISCAL COSTS, FINANCIAL SECTOR, BANK REGULATION VARIABLES DATA, G20, SPAIN AND NETHERLANDS ..........................116

TABLE 6.3: UNCONDITIONAL PROBABILITIES OF ONE INTERVENTION........ 128

TABLE 6.4: LOGIT REGRESSION RESULTS FOR ONE INTERVENTION ............. 129

TABLE 6.5: UNCONDITIONAL AND CONDITIONAL PROBABILITIES FOR TWO

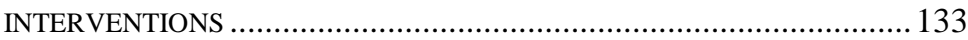

TABLE 6.6: LOGIT REGRESSION RESULTS FOR A MIX OF TWO INTERVENTIONS 134

TABLE 6.7: UNCONDITIONAL AND CONDITIONAL PROBABILITIES FOR THREE

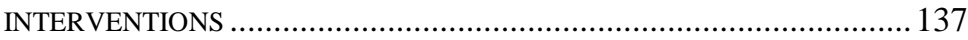

TABLE 6.8: LOGIT REGRESSION RESULTS FOR A MIX OF THREE

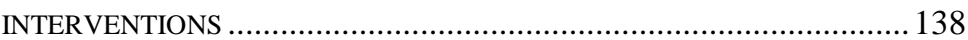


APPENDIX 3-A / TABLE 1: MinIMUM INCOME GUARANTEES PER SECTION FOR ROUTE 5 PROJECTS, NOMINAL VALUES IN MILLION CH\$, YEARS 1998-2007

APPENDIX 3-A / TABLE 2: MINIMUM INCOME GUARANTEES PER SECTION FOR ROUTE 5 PROJECTS, DISCOUNTED VALUES IN MILLION CH\$, YEARS 1998-2007.

APPENDIX 3-A / TABLE 3: EXPECTED REVENUE PER SECTION FOR ROUTE 5 PROJECTS, NOMINAL VALUES IN MILLION CH\$, YEARS 1998-2007.166

APPENDIX 3-A / TABLE 4: EXPECTED REVENUE PER SECTION FOR ROUTE 5 PROJECTS, DISCOUNTED VALUES IN MILLION CH\$, YEARS 1998-2007

APPENDIX 3-A / TABLE 5: DETAILED TABLE OF GUARANTEES, EXPECTED REVENUES AND NET CONTINGENT FLOWS FOR ROUTE 5 PROJECTS, DISCOUNTED VALUES IN MILLION CH\$, YEARS 1998-2007 ............. 166

APPENDIX 3-B / TABLE 1: CHILEAN GOVERNMENT SURPLUS / DEFICIT, INVESTMENT COST, PROJECT REVENUES, CUMULATIVE VALUES, MILLION CH\$, YEARS 1990-2007

APPENDIX 3-B / TABLE 2: CHILEAN GOVERNMENT DEFICIT/SURPLUS, TyPiCAL Public InVESTMENT VS. PUBliC-PRIVATE PARTNERSHIP, CUMULATIVE VALUES, MILLION CH\$, YEARS 1990-2007 ................ 168

APPENDIX 3-B / TABLE 3: CHILEAN GDP, GROSS CONSOLIDATED DEBT, DEBT TO GDP RATIO, NOMINAL VALUES IN MILLION CH\$, YEARS 1990-2007

APPENDIX 3-B / TABLE 4: CHILEAN GOVERNMENT DEFICIT/SURPLUS, NOMINAL VALUES IN MILLION CH\$, YEARS 1990-2007 .................. 169

APPENDIX 3-B / TABLE 5: CHILEAN GOVERNMENT DEFICIT/SURPLUS AND TOTAL NET CONTINGENT FLOWS, CUMULATIVE VALUES, MILLION

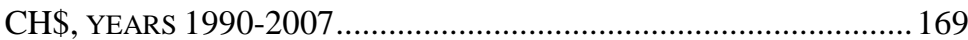

APPENDIX 3-E / TABLE 1: S \& P CORPORATE DEFAULT RATES .................. 176

APPENDIX 3-F / TABLE 1: INFRASTRUCTURE BOND RATINGS, ROUTE 5 PROJECTS 179

APPENDIX 3-F / TABLE 2: UNCONDITIONAL DEFAULT PROBABILITIES AND SURVIVAL PROBABILITIES, ROUTE 5 PROJECTS, YEARS 1998-2007. 179

APPENDIX 3-F / TABLE 3: UNCONDITIONAL DEFAULT PROBABILITIES AND SURVIVAL PROBABILITIES, CHILEAN GOVERNMENT ........................ 184

APPENDIX 3-G / TABLE 1: PRESENT VALUE OF EXPECTED CDS PAYMENTS, ROUTE 5 PROJECTS, NO COUNTERPARTY DEFAULT......................... 185

APPENDIX 3-G / TABLE 2: PRESENT VALUE OF ACCRUAL CDS PAYMENTS, ROUTE 5 PROJECTS, NO COUNTERPARTY DEFAULT........................... 186

APPENDIX 3-G / TABLE 3: PRESENT VALUE OF EXPECTED CDS PAYOFFS, ROUTE 5 PROJECTS, NO COUNTERPARTY DEFAULT........................... 187 APPENDIX 3-G / TABLE 4: PRESENT VALUE OF EXPECTED CDS PAYMENTS, ROUTE 5 PROJECTS, COUNTERPARTY DEFAULT ............................... 188

APPENDIX 6-B / TABLE 1: ASSET MANAGEMENT, LIABILITIES MANAGEMENT AND EQUITY MANAGEMENT VARIABLES ............... 199 
APPENDIX 6-B / TABLE 2: GOVERNMENT INTERVENTIONS FISCAL COSTS IN $\%$ OF GDP, G20, SPAIN AND THE NETHERLANDS ............................ 200 APPENDIX 6-B / TABLE 3: FINANCIAL SECTOR VARIABLES....................... 201 APPENDIX 6-B / TABLE 4: MACROECONOMIC VARIABLES ....................... 202 APPENDIX 6-B / TABLE 5: BANKING REGULATION VARIABLES................ 203 APPENDIX 6-C / TABLE 1: FINANCIAL SECTOR VARIABLES, 2007 ............ 205 APPENDIX 6-C / TABLE 2: MACROECONOMIC VARIABLES, 2007.............. 206 APPENDIX 6-D / TABLE 1: LOGIT REGRESSION RESULTS FOR ONE INTERVENTION (WITH STANDARD ERRORS AND CONFIDENCE

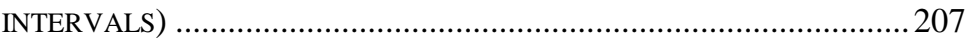

APPENDIX 6-D / TABLE 2: LOGIT REGRESSION RESULTS FOR A MIX OF TWO INTERVENTIONS (WITH STANDARD ERRORS AND CONFIDENCE

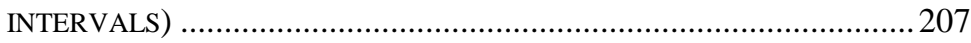

APPENDIX 6-D / TABLE 3: LOGIT REGRESSION RESULTS FOR A MIX OF THREE INTERVENTIONS (WITH STANDARD ERRORS AND CONFIDENCE INTERVALS) 208 


\section{List of Boxes}

BOX 3.1: ONE-TAILED T-TEST FOR CONSOLIDATED ASSETS AND CONSOLIDATED DEBT WITH A 95\% CONFIDENCE INTERVAL, DESCRIPTIVE STATISTICS. 51

BOX 3.2: TWO-TAILED T-TEST FOR GUARANTEES AND EXPECTED REVENUES WITH A 95\% CONFIDENCE INTERVAL, DESCRIPTIVE STATISTICS........54 APPENDIX 3-C / BOX 1: NORMALITY TESTS FOR GUARANTEES (SHAPIRO WILK, ANDERSON - DARLING, LILLIEFORS, JARQUE - BERA) .......... 170 APPENDIX 3-C / BOX 2: NORMALITY TESTS FOR EXPECTED REVENUES (SHAPIRO - WilK, ANDERSON - DARling, Lilliefors, JARQUE BERA)

APPENDIX 3-C / BOX 3: NORMALITY TESTS FOR CONSOLIDATED ASSETS (SHAPIRO - WilK, ANDERSON - DARling, LiLliEFORS, JARQUE BERA)

APPENDIX 3-C / BOX 4: NORMALITY TESTS FOR CONSOLIDATED DEBT INCLUDING NET CONTINGENT FLOWS (SHAPIRO - WILK, ANDERSON DARLING, LILLIEFORS, JARQUE - BERA) 


\section{Introduction}

“(...) Critobulus: It must, I should think, be the business of the good economist at any rate to manage his own house or real estate well.

Socrates: And supposing another man's house to be entrusted to him, he would be able, if he chose, to manage it as skillfully as his own, would he not? (...) Then there is no reason why a proficient in this art, even if he does not happen to possess wealth of his own, should not be paid a salary for managing a house, just as he might be paid for building one?

Critobulus: None at all: and a large salary he would be entitled to earn if, after paying the necessary expenses of the estate entrusted to him, he can create a surplus to improve the property (...)"

a discussion on the essentials of economy between Socrates and Critobulus from "The Economist (1)," The Works of Xenophon

\subsection{Public-private partnerships in public policymaking}

The above discussion introduces a relevant issue on efficient public property management. The "man's house," as set by Socrates, represents a public investment program for infrastructure and / or provision of public goods. If this "man", the government, wishes to transfer specific activities of typical public procurement to a "good economist," namely a private actor, it can initiate a public-private partnership (PPP) program. In that case, even if the private actor "does not happen to possess wealth of his own," he can "be entrusted" with developing a specific part of the infrastructure, or supplying the public good and "being paid a salary" for managing this "house." This can take the form of either a direct payment from the government, or a fee charged to end users. The result will be a "surplus" that the private partner will create, in order to improve this property.

There are numerous definitions of PPPs from different entities (OECD, 2008, IMF, 2004b, EIB, 2004 and Eurostat, 2004). The definition we select incorporates the effect of 
public exposure on the national accounts. In this study, we define a public-private partnership as "a contractual agreement for a shift of the supply of a good or a service, or the construction of an infrastructure asset, from the government to the private sector, where efficient risk allocation among the partners, and transparent recording of all government obligations, future and contingent, are of utmost importance." There are decisive features that characterize a project as a PPP. The private partner a) designs, builds, finances, operates and manages a project; b) transfers the asset back to the public partner; and c) receives a stream of payments from the government or charges fees to end users. Other PPP formats include the purchase or lease of an existing government asset by a private actor, with or without the obligation to transfer it back to the public actor.

Market failures that may arise during the production of a public good, leave space for the realization of PPP initiatives. The production of public goods by the private sector serves various objectives, such as financing fiscal deficits, easing government debt, attracting foreign and domestic investment, liberalizing and deregulating target sectors and improving corporate effectiveness (Megginson and Netter, 2001). PPPs nowadays exist in many advanced and developing countries as a tool to better manage public activities. They are widely implemented in various sectors, such as energy (electricity, gas), water and sewerage, telecommunications, education, health and most commonly, transportation infrastructure (airports, seaports, roads, bridges, rail etc.).

PPPs can impose important future cost on the government, which in turn create obligations similar to public debt obligations for financing infrastructure investment. It may be that governments use PPPs to reduce their current spending, and transfer present cost to the future creating an immediate fiscal impact. Apart from that, government guarantees, typical in PPP contracts, legally bind the government to accept an obligation should specific future events occur (such as defaults). These guarantees constitute 
explicit contingent liabilities, which must be valued, quantified and disclosed within an appropriate fiscal context. If a substantial amount of such exposures is transferred to the public sector off-budget, this can create a false picture of the country's fiscal profile. Respectively, the risk that arises from PPPs, and more specifically one that is generated via government guarantees, must be transparently valued in the framework of the national accounts, to estimate the actual level of public debt. This valuation is imperative, both from a financial (investment in a government bond) and a macroeconomic (inclusion of contingent liabilities in the national accounts) perspective. In this study, we observe both viewpoints assessing the direct and contingent PPP net cash flows.

Clearly, there is a link between public contingent liabilities and banks' off-balance sheet operations. The rapid growth of banks' off-balance sheet exposures is classified among the main reasons for credit crises, and renders risk management as a difficult and complicated assessment. Recent crisis episodes have clarified the need for the inclusion of offbalance sheet and on-balance sheet risk in the overall risk profile of private and public entities. The PPP risk that sources from the private partner's probability of default is similar to the credit risk that is involved in a bank's off-balance transaction. For example, government PPP guarantees can be regarded as direct credit subsidies, since their respective risk is considered similar to an on-balance sheet exposure and equivalent to the risk of a state loan or a bond. This is the first indication for the link between PPPs and government interventions as crises remedies. These actions can be clearly considered as PPPs, because they reflect direct partnerships between a public (government) and a private (bank) partner. The recent crisis, initiated in the second half of 2007, and its relevant responses serve as a solid policy example for such types of partnerships. 


\subsection{Main research questions}

As described in the previous paragraph, this study covers two main issues with one common determinant: the contingencies in the form of public sector exposures (for example, guarantees). We discuss two aspects of guarantees, being guarantees as a common element in PPP contracts, and guarantees as a major crisis remedy. ${ }^{1}$ Our main "problem" concerns the valuation of the public exposures that source, either from pure PPPs or from government interventions, to re-stabilize the financial system following a crisis. The two principle research questions are:

Question 1: Under what conditions should governments engage in alternative types of PPPs in order to minimize the net negative effects on national debt in a national accounts framework, arising from direct PPPs and the impact of government guarantees arising from such PPPs, taking into account risk pricing.

Question 2: Realizing PPPs as a policy tool in a banking crisis incident, what are: a) the effects of these partnerships on sectoral balance sheets, b) the basic determinants of the governmental decisions to intervene during and after the crisis and c) the most efficient interventions in terms of total public exposure and neutrality?

\subsection{Public-private partnerships and crisis remedies: the connection}

The private sector participates in public activities in numerous ways. The most direct paths for private interference are via privatization schemes, ${ }^{2}$ subcontracting and public-

\footnotetext{
${ }^{1}$ In case the remedy incorporates a public-private partnership, that between the government and a bank.

2 According to Megginson and Netter (2001), over one trillion US dollars worth of State-Owned Enterprises (SOEs) had been sold by governments to private economic agents worldwide by the end of the last century.
} 
private partnerships. ${ }^{3}$ The main goal of these public-private activities is to produce a public good or service.

There are also indirect channels for private actors to participate in state motion. A significant and (always) up-todate interaction between public and private entities occurs when dealing with financial crises. "Financial crises can be damaging and contagious, prompting calls for swift policy responses." (Laeven and Valencia, 2008). But these policy responses require collaboration and consensus between the private (banking) sector and the public sector on a contractual basis. They constitute, in essence, a PPP. Following the definition that we give on PPPs, the government contractually assigns the private partner to supply a good or to build an asset. Even if the "product" or the "asset" is not obvious at first sight in the case of government interventions, there are clear indications that the latter constitutes a similar partnership. The government has to act bilaterally with the banks as private actors, with a specific partnership product: the restoration, re-stabilization and "reconstruction" of the financial system on an international basis. The government interventions via the banking system to restore confidence in the financial sector can be considered a PPP portfolio, since this contains many projects that incorporate contractual agreements between governments and the private sector (banks). ${ }^{4}$

This link is the prime interest of the present study. The channels through which PPPs on the one hand ${ }^{5}$ and crises remedies schemes on the other hand ${ }^{6}$ affect the national

\footnotetext{
${ }^{3}$ We need to clarify that we do not consider that PPPs result from privatization. On the contrary, in the contextual analysis further on, we clearly distinguish between the two.

${ }^{4}$ In this occasion, we acknowledge that the particularities of the banking sector can be multifaceted to the analysis because the main service that banks provide concerns an immaterial product: a well-functioning nondisrupted payments system. However, the significance of this product to other sectors of the economy and its inelastic social demand can render it as a public good.

${ }^{5}$ Chapters two and three.

${ }^{6}$ Chapters four, five and six.
} 
accounts and the fiscal sustainability are studied in the analysis that follows. We attempt to approach the two different subjects on common ground. The common reference points that concern PPPs and crises remedies are:

a) government guarantees as an element in PPP contracts and in asset and liability management crisis measures;

b) the (potential) fiscal costs and government budget constraints as a main determinant in both actions;

c) the common accounting approach to assess direct and indirect effects of PPPs and interventions, and;

d) the similar valuation techniques (such as option pricing) to evaluate (mainly) the contingencies that arise from such joint contracts.

In this section we elaborate on how partnerships between banks and governments for policy interventions and PPPs share various mutual features.

\subsubsection{Budget affordability and value for money}

Affordability refers to a specific project falling within the intertemporal budget constraint of the government (OECD, 2002). In principle, when implementing a project, two reverse flows may exist: revenue inflows and capital outflows. Respectively, there is a positive net worth for the government in the case when there is a surplus and a negative net worth in the case of a deficit. For a PPP, these flows are usually straightforward, as we discuss in chapter three. However, when implementing a government intervention to tackle a crisis, the potential benefits are indirect in nature, while the fiscal costs are more observable. Both policies share a very decisive common feature, being the fact that significant determinants of PPPs and crisis remedies constitute offbalance sheet activities. Therefore, the PPP impact on the national accounts and the inclusion of the project within the government budget constraint should be cautiously assessed. For example, government guarantees that are used in PPPs and in government interventions cannot be reflected directly in the government balance due to their off-balance sheet nature 
(IMF, 2004b). Respectively, the contingent obligations that arise from these guarantees are not evaluated when the affordability of the project within the government budget constraint is assessed.

A project can be considered efficient for the government if it increases the value for money compared to other alternatives (OECD, 2002). In our case, PPPs are acceptable within the government budget if their value for money exceeds the value for money of the same project, should this be realized by typical public procurement. The same approach for government interventions during crises is useful in terms of the necessity and magnitude of interventions. In the G20 dataset that we use for assessing these measures, we observe that not all countries followed the same path of intervening measures. While some countries chose not to intervene, we also indicate different countryspecific approaches and alternative interventions. These policy decisions are driven, among others, by their governments' prospective efficiency and value-for-money evaluations of the interventions. The two basic areas to compare in the latter case are the fiscal costs of each intervention and the economic costs of the negative externalities of the crisis.

\subsubsection{The public risk exposure and the inelasticity of social demand}

PPPs and government interventions to restore the financial sector both incorporate specific provisions for risk taking from the government. In chapter two, we analytically categorize the different types of PPP risk that the public and the private sector assume, and we derive the alternative risks that emerge from different government interventions. We also emphasize the importance of the proper risk allocation among parties, and the necessity that the government assumed risk will be manageable. In other words, the government should only bear the risk if the following conditions are met: a) the government is in a better position to manage the risk compared to the private partner (PPP contractor or bank) and b) the government can deal with the risk at minimal cost 
(OECD, 2008). Risk allocation and risk transfer is very important when implementing a PPP, while the overall government risk exposure is crucial when realizing crisis remedies. In any case, for both activities, the proper analysis of the risk that the public sector assumes, constitutes a mutual and decisive element.

Risk is defined as the measurable probability that the actual outcome will deviate from the expected outcome. Two subcategories of risk can be identified: individual project risk and market risk. The former, referring to either a single PPP project or a specific intervention seen as a project (or a portfolio of projects), follows the Modigliani Miller theorem (Modigliani and Miller, 1958) that develops the capital structure irrelevance principle. One of their main findings is that the cost of capital depends only on the overall project risk. With perfect markets, there is no reason for the government to assume this risk. However, with imperfect markets, the government should be in a better position to manage this risk, since it can be spread over taxpayers' contributions (Arrow and Lind, 1970). Apart from individual project risk, the government faces market risk as well. This sources from variability of financial market determinants, such as interest rates, and from macroeconomic shocks. These shocks are assessed as the main unknown factor that differentiates the market and the historical value of a bank's assets in chapter five. In most cases, the individual project risk is diversifiable across a large number of public projects, only capturing the variation of single projects. However, market risk cannot be diversified, neither when implementing a PPP, nor when intervening to heal the financial sector. This is why the pricing of this type of risk is significant in both cases and it represents a focus point throughout our analysis.

Efficiency and performance of a PPP service, or a government intervention, also depend on the final output that is delivered. Some public goods are described as goods with inelastic social demand. In other words, the delivery of the specific product is so important to the public interest that the government cannot risk non-delivery. Furthermore, should the 
private actor (either the partner in the PPP or the bank) be aware of this inelasticity, then the government is forced to assume more risk, or bail-out the project. It is a fact that many PPP products are characterized with highly inelastic social demand (OECD, 2008), as is the social demand for the rescue of the financial system. This inelasticity creates moral hazard on the private sector's side. If the private partner in a PPP knows that the government has to deliver the product, it does not "care" so much about the realization of the project. In addition, systemically important financial institutions, certain that the government will bail them out, also display reduced interests to comply with their obligations. This moral hazard may constitute risk allocation as highly inefficient.

\subsubsection{Public-private partnership guarantees and asset and liability crisis management}

A government guarantee legally binds a government to accept an obligation should a specific event occur (IMF, 2001). Government obligations, depending on different degrees of uncertainty can take various forms. ${ }^{7}$ Guarantees are categorized as contingencies with the least certainty among the above liabilities (Stickney and Weil, 2000). The uncertainty, on the government's side, to assume the obligation lagging behind the guarantee, raises issues concerning the accounting and statistical treatment and the fiscal transparency of the guarantee. Furthermore, it is very difficult to evaluate the effectiveness of a guarantee scheme and to compare it with other alternatives. A guarantee could be used for other reasons rather than efficiency, such as bypassing budgetary constraints and moving potential government obligations off-budget.

These guarantees are directly linked to the government risk exposure since they are intended to reduce the financial costs of individual project risks, should they materialize. Guarantees appear in PPP contractual agreements in the form

\footnotetext{
${ }^{7}$ Such as debt instruments, un-invoiced accounts payable, pension, social security or other insurance schemes, operating leases, warranties and indemnities, assistance to public enterprises or various others (IMF, 2001).
} 
of either explicit revenue, demand guarantees or financial guarantees. ${ }^{8}$ As far as crisis remedies are concerned, asset management - among others - features guarantees for future losses from "bad" assets, while liabilities management refers mainly to deposit and debt guarantees. The link is straightforward. In both cases, guarantees constitute explicit contingent liabilities of the government, should they be called. Even if they do not appear on the government's balance sheet but only as a memorandum item (IMF, 2001), they constitute a substantial obligation from the public side, if the PPP private partner on the one part or the bank on the other, defaults and the guarantee is triggered.

Another common feature is the control and budgeting of guarantees. Specific thresholds of maximum risk exposures on a budget constraint must be set, while entities that benefit from guarantees (such as PPP private partners and systemically significant financial institutions) ought to be financially and managerially monitored. Should the government consider implementing a PPP or a crisis intervention program, it must accentuate the future costs of the relevant guarantees on its budget. Reasonable earmarking of these guarantees, not as additional funds but more like appropriations for expected lifetime guarantee costs, can provide a more consistent budgetary image. We value guarantee provisions for both PPPs and crisis interventions, with common accounting and finance methodology.

The contingent nature of guarantees makes their accounting and valuation a difficult and challenging task. This is because the guarantee is accounted for in the national accounts only when it is called (Navarro, 2005). We argue that, in order to properly address the fiscal condition of a country, the potential cost of government guarantees must be considered. We introduce credit default swap valuation to compute a total value of a PPP guarantee at a specific time (chapter three), while we use accrual accounting to see the

\footnotetext{
8 Financial guarantees incorporate debt guarantees (the government appears as a guarantor for the debt of the PPP consortium) or interest rate and inflation guarantees (IMF, 2001).
} 
effect on the national and banking sectors' extended balance sheets, when implementing a guarantee scheme as a crisis intervention (chapter five). Thus, we approach both actions using prominent finance and accounting principles. Since guarantees are formally recognized as liabilities creating a provision only when they are called, they cannot be accounted for immediately. However, evaluating these liabilities using derivative valuation techniques, allows us to compute the contingent amount and to recognize this obligation as a financial derivative. The latter is in line with the government finance statistics manual (IMF, 2001), where a contingent obligation is treated as a liability only in the case when the contingent contract relates to a financial arrangement that can be substantially valued. Thus, policymakers can consider the different scenarios of alternative levels of maximum public risk exposure from guarantees, when assessing fiscal perspectives.

\subsection{Contribution}

\subsubsection{Evaluating government contingencies in public-private partnerships}

Chapters two and three discuss various aspects of public-private partnerships with a main focus on contingent obligations that arise from such partnerships, and the effect of the obligations on the national accounts. There is a growing literature that links PPPs and subjects, such as fiscal risk, contingent commitments, accounting treatment, classification of the PPP asset and macroeconomic effects. We present this literature in chapter two and extend it by further discussing issues of optimal risk allocation, demand risk, competition and externalities. We also categorize different PPP schemes and the risk that arises from these contracts. Our main contribution to the literature is the introduction of arguments on the short and long term direct impact of PPPs on government budget, public debt and fiscal sustainability. This effect is directly linked to government risk in the form of contingencies, such 
as guarantees, compelling the government to realize an obligation if a specific event occurs.

Following the literature review, it is obvious that the key determinants in this process to follow up on, are the net contingent flows that arise from relevant commitments of the PPP project. These contingencies have to be precisely valued and disclosed. Therefore we introduce in chapter three a scenario-based model to evaluate the effect of such commitments, namely guarantees. Using the Chilean PPP program as unit of analysis, we propose a four-scenario valuation approach that captures the PPP effect in the national accounts, focusing on government balance and public debt. ${ }^{9}$ Another important input of chapter three is the viewpoint of a government bond as a call option and the guarantee effect on that investment. We assess more accurately the probability of default of the government, which primarily determines the investor's decision as the equity holder.

\subsubsection{Assessing government decisions and commitments as focused interventions}

The linkage between the PPP off-balance sheet exposures and the credit crisis, as discussed previously, is straightforward. The U.S. subprime mortgage market crisis in the second half of 2007 constituted the raison d'etre of the global credit crunch. The mutation to other sectors, such as the non-financial, the public and the external sector, became a serious concern and constituted a dangerous liaison in many countries. Following this turmoil, there were immediate but also longer term responses by local governments and international organizations, to deal with systemic imbalances, and provide solutions, mainly in terms of liquidity and solvency. These government interventions constitute a PPP in

\footnotetext{
${ }^{9}$ In the first two scenarios we compare the typical public investment to the PPP case. In the other two scenarios we recommend credit default swap (CDS) valuation to calculate the mid-market CDS spread which depicts the value of the commitment, both excluding (third scenario) and including (fourth scenario) counterparty default.
} 
the banking sector, which results in a specific product: the restoration of the financial system.

Chapters four, five and six discuss crisis interventions that were implemented in order to overcome the negative effects of the crisis in the banking system. The main contribution of chapter four is that through a simple balance sheet approach, we introduce a straightforward categorization of government interventions, as asset, liabilities and equity management. We argue on the specific aims and risks of each of the above groups and we conclude by proposing the most efficient intervention in terms of the restoration of trust in the banking system.

Chapter five introduces the balance sheet approach to government interventions. While previous literature (Honohan and Klingebiel, 2003, Laeven and Valencia, 2008, IMF, 2009b, IMF, 2009d, IMF, 2009e) mainly focused on the classification and the fiscal costs of crisis remedies, we observe the balance sheet effect of each group of remedies separately, using two sectoral balance sheets, one from the public and one from the banking sector. We follow the ex post effect of each measure or a combination of measures and assess their neutrality and level of influence, in terms of balance sheet totals and capital requirements. As unit of analysis, we use actual averages of fiscal commitments from the G20 governments. Another contribution of the chapter is the isolation of the macroeconomic shock (Dewatripont and Tirole, 1993) as the unknown factor that makes the valuation of distressed bank assets and the estimation of the value of the bank as a firm, both very difficult tasks. This, together with the discussion on methods for guarantee valuation, leads us to novel arguments on the most efficient and transparent crisis intervention that can be applied. Thus, having discussed the balance sheet effect and the off-balance sheet nature of each group of remedies, we are in a position to extend our study to a decision choice analysis in chapter six.

In chapter six we unlock the decision box of a government policy action against the crisis ex ante, by identifying its most significant determinants. This is the prime 
contribution of the chapter, since previous literature has assessed the consequences and the potential costs and benefits of previous crisis episodes, leaving a gap in the detection of the variables that affect the governmental decision to intervene. We use the G20 dataset which captures asset, liabilities and / or equity management decisions and propose a three-step process than includes the calculation of (conditional and unconditional) probabilities, and measures the effect of relevant control variables. During the first step, we observe how specific variables influence the decision of governments to implement an intervention. Then, given a crisis measure, we analyze the governmental decision to implement another measure and, finally, we indicate an auxiliary intervention, given that the government has already implemented two interventions. Thus, we cover all possible combinations of policy decisions that can be applied.

Chapter seven contains a summary and conclusion, based on the above indicated pieces of analysis. 


\section{Public-private partnerships, the government budget and risk implications}

\subsection{Introduction}

In this chapter, we start by describing PPP schemes and the numerous risks that arise from these contracts. We also present previous work that has been done on risk allocation and risk transfer issues between the public and the private partner(s) in a PPP contract. The main research question that we address in this chapter is twofold. First, we review the direct impact of PPPs on the government budget and the public debt. Second, we discuss the long term impact of PPPs on fiscal sustainability, taking into account future PPP payments and contingent obligations. These obligations constitute, in essence, guarantee provisions under the PPP contract.

The framework introduced in this chapter, will be used in the two subsequent chapters, where we present a quantitative analysis of PPPs. The remainder of this chapter is set up as follows. First, in section 2.2 we discuss the existing literature on PPPs. Next, in section 2.3 we set the stage by formally defining what constitutes a PPP. In section 2.4 , we review the link between PPPs and the (sustainability of the) government budget. The role of risk allocation in structure of the PPP is discussed in section 2.5. In Section 2.6, we consider the role of government guarantees as contingent liabilities.

\subsection{Literature linkages}

The literature concerning the fiscal considerations of public-private partnerships, although growing, is still in its infancy, since PPPs have only recently emerged globally and their reporting and accounting treatment is yet an issue of international debate. However, important studies exist, mainly from IMF staff, who are leading the way in the field.

\subsubsection{The IMF on fiscal risk and government guarantees}

The Fiscal Affairs Department of the IMF, in consultation with other IMF departments, the World Bank and 
the Inter-American Development Bank, has published a series of board papers on PPPs and their relation to fiscal policy and risks, government guarantees and public investment. One of these papers (IMF, 2004b), consists of an overall assessment of PPPs, defining them, connecting them to risk transfer and pinpointing the absence of standardized fiscal accounting and reporting guidelines. Its authors conclude that a particular concern of using PPPs is to bypass spending controls and move public investment off-budget, making the national accounts to appear improved and the fiscal burden more sustainable. However, they emphasize that if the government still bears most of the risk of the investment, then PPPs are not necessarily more efficient than public investment and the supply of the good from the government. Finally, they mention that even if there is a straightforward way to report PPPs, the accounting of PPPs that involve limited risk transfer to the private sector remains complex.

An IMF broad paper (IMF, 2005a) covers the fiscal risk in a framework of government guarantees, many of which arise from PPP agreements. The main observation is that, since such guarantees are assumed to be contingent liabilities, they should be transparently reported, accurately valued and comprehensively disclosed. It is also stressed that uncertainty created by government guarantees, any complications aside, should definitely be considered when assessing debt sustainability. A similar paper on public investment and fiscal policy (IMF, 2004a), refers to PPPs as a method to reverse the declining trend of public investment. It discusses the lessons gained from the PPP experience, underlining that, apart from potential efficiency gains, PPPs can also involve significant costs and risks for the government in the long-run. Finally, the imperative need for an internationally accepted accounting treatment and disclosure of PPPs is also accentuated. A recent board paper reviews policy lessons from a group of eight pilot country studies, including issues related to fiscal implications of PPPs (IMF, 2005b). It infers that PPPs offer limited means to increase infrastructure investment, provided that they are suitably designed. However, they stress that PPPs are no 
panacea, and that they should be driven by increased efficiency and not by incentives to move expenditure offbudget.

A group of IMF staff led by Richard Hemming (2006) studied PPPs in the framework of government guarantees and fiscal risk. Their introductory remark is that PPPs offer benefits similar to those of the sales of government assets to the private sector, and recently, they have been more commonly used than conventional privatization schemes. Comments on the possible use of PPPs to move government expenditure off-budget, expand the work of the IMF. Additionally, the authors underline that their accounting methodology is not internationally broadened and that a significant amount of risk should be transferred to the private sector. They, then, refer to government guarantees in the framework of PPPs, and their treatment in the national accounts; if such guarantees are used to secure private financing, they can expose the government to considerable risk, since they give rise to explicit contingent liabilities. They also focus on the appropriate debt sustainability approach, addressing the uncertainty created by guarantees, and proposes two equivalent methods to achieve sustainable debt. Finally, they suggest measures to minimize the fiscal risk associated with PPPs.

\subsubsection{Macroeconomic and accounting viewpoints}

Other studies look at the macroeconomic and fiscal implications of PPPs. A decision by Eurostat (2004) specifies the PPP impact on government deficit/surplus. It defines three main categories of "generic" risk (construction, availability and demand risk) and clarifies the cases when the government is assumed to bear most of each risk. If there is strong evidence that the government bears most of the PPP risk, then the asset is classified as a governmental asset in its balance sheet. Fourie and Burger (2001) define PPPs and their risks and assess the fiscal implications of PPPs from an accountant's perspective. They reject the idea that, since the private partner takes on the initial capital expenditure, 
government spending is reduced. They assume that PPPs are merely a different kind of arrangement from a public investment financed by taxes or government borrowing. They also examine the effect of PPPs on fiscal indicators such as budgetary balances, taxes and user charges and isolate the importance of the treatment of depreciation of PPP assets. They conclude that the fiscal implications have to be well understood, especially with reference to the very long, or even unlimited lives of public assets. These assets are depreciated by private operators, who have a tax incentive to prolong the depreciation of the PPP asset.

Dewatripont and Legros (2005) emphasize two aspects of PPP schemes: firstly, the costs associated with the choice of PPP investment and contracts are internalized by the partners, and secondly, there are underlying costs of completing PPP agreements, which can equilibrate traditional public procurement cost overruns. They deduce that, apart from the endogenous uncertainty arising from PPPs, exogenous uncertainty should be accredited, in terms of rising external finance to transfer financial risk to third parties. Sadka (2006), giving a public economics' perspective, agrees that PPPs can be considered as a tool to evade expenditure controls and hide budget deficits, since the public investment can be spread over future budget years. "But there is nothing inherent in PPPs that leads inevitably to fiscal laxity and imprudence" (Sadka, 2006, page 25). He concludes by highlighting the importance of the transparent accounting and evaluation of all government liabilities. Navarro (2005) provides guidance on how to record PPPs in the national accounts according to the Government Finance Statistics Manual (GFSM). He deduces that, since the government is a purchaser of the PPP product and a bearer of a substantial amount of risk, the national accountants should record the acquisition of PPP assets and recognize future PPP payments as actual liabilities. Engel et al. (2008), using an optimal risk-sharing contract approach, raise the issue of whether PPPs should be considered as temporary privatization or as another option to procure public services. The authors conclude that - from a government's budget risk profile - PPPs 
are closer to public procurement and that they should be treated akin to public projects.

\subsubsection{Contract theory, syndicated lending and the public- private partnership link}

As aforementioned, PPPs differ from privatization schemes. A fundamental distinction is the level of accountability for the delivery of the PPP product or service. While the private actor is solely responsible in the case of pure privatization, in the PPP case the final responsibility remains with the public partner. Responsibility and accountability of PPP contracts are assessed with contract theory, with the main objective being the design of an optimal contract that minimizes adverse selection and moral hazard.

There is a growing literature (Bolton and Dewatripont, 2005, Dewatripont and Legros, 2005, Hart, 2002, Tirole, 1999, Salanie, 1997) that deals with contract theory (some of which incorporates PPP specifics as well) and emphasizes various aspects of incomplete contracting. The theory of incomplete contracts describes how particular contractual clauses can deal with information asymmetries and missing parts of the contract or unanticipated contracting probabilities ex post. Such contracts are directly linked with the existence of transaction costs. Our main argument is that four decisive features of PPP contracts can attribute to incomplete contracting: a) the contingent public-side liabilities, b) the issue of risk allocation, c) the nature of the PPP project as a hybrid "entrepreneurial" scheme, which lies between the private and the public sector, and d) the typical long-term format of PPP project duration (usually more than 20 years).

The long-term lifespan of the contract also increases the probability of unforeseen events to occur, many of which can be actually unobtrusive. Bolton and Dewatripont (2005) verify that most long-term contracts (typically PPPs) are highly incomplete, since it is impossible to consider all potential events (including public sector contingencies) through the duration of the project. Finally, the proper risk 
allocation and management is found to be a decisive feature in a PPP project and an issue of contract negotiation ex ante.

Apart from contract theory, syndicated lending shares specific common features with PPP financing. While the market of syndicated lending has significantly grown in size, syndicated loans constitute a hybrid of private and public debt (Dennis and Mullineaux, 2000). This exact hybrid public/private format is similar to the PPP financing scheme and more specifically to the special purpose vehicles (SPVs) that are created to this effect. Sufi (2007), in his paper on information asymmetries of syndicated lending, notes that if borrowers seek intense monitoring, "the lead arranger attempts to guarantee diligence in investigation and monitoring by increasing their risk exposure to the loan" (Sufi, 2007, page 37). Credit monitoring is a very important aspect to the financing of the PPP project via an SPV as well, while public PPP guarantees are the most significant indicator of credit risk. Further research on syndicated lending (Bolton and Scharfstein, 1996 and Lee and Mullineaux, 2004) also emphasizes on the importance of renegotiation and debt restructuring (which is a typical feature of long-term PPP contracts) and its relationship with the number of lenders and limited information.

In parts to follow, we expand, in detail, on risk analysis. In any case, the complexity and variation in the methods of risk allocation among contractors, increases the transaction costs for all the phases of the PPP project (tender and implementation) and results in a greater number of incomplete contracts.

\subsection{Public-private partnerships}

\subsubsection{Public-private partnership definitions}

Public-private partnerships are set between traditional public procurement and full privatization schemes. However, there does not seem to be a single definition of PPPs. The reasons for this are the wide range of PPP projects, the gap between typical public investment and privatization and the 
variation of asset ownership and capital expenditure, moving from management contracts - that minimize private ownership - to full scale PPP schemes with possibilities of asset transfer to the state. The OECD defines PPPs as "an agreement between the government and one or more private partners according to which the private partners deliver the service in such manner that the service delivery objectives of the government are aligned with the profit objectives of the private partner..." (OECD, 2008, page 21). According to the IMF, "PPPs refer to arrangements where the private sector supplies infrastructure assets and services that traditionally have been provided by the government" (IMF, 2004b, page 4). A broader definition is given by the European Investment Bank: "[A] generic term for the relationships formed between the private sector and public bodies with the aim of introducing private sector resources and/or expertise in order to help provide or deliver public sector assets and services" (EIB, 2004, page 2). An even more general definition is given by the European Commission, for whom the term refers to "forms of cooperation between public authorities and the world of business, which aim to ensure the finding, construction, renovation, management and maintenance of an infrastructure of the provision of a service" (Eurostat, 2004, page 1).

For the purpose of this thesis, we define a publicprivate partnership as a contractual agreement for a shift of the supply of a good or a service, or the construction of an infrastructure asset, from the government to the private sector, where efficient risk allocation among the partners and transparent recording of all government future and contingent obligations are of utmost importance.

There are specific characteristics that constitute a PPP. The private partner designs, builds, finances, operates and/or manages the project, while prior public procurement procedures decreed that it was involved only in either the construction, or the operation of the asset, or only provided financing to the project. The private partners receive a stream of payments from government appointed bodies or charge a 
fee to the end users of the service. On the other hand, the government agrees upon the quantity and quality of the product or service of the PPP project. In the cases where the government is responsible for payments to the private partner, these may depend on and/or be connected to its compliance with the contractual obligations and the timely delivery of the predetermined quality and quantity. A typical tool to organize the private partners of a PPP contract is a special purpose vehicle (SPV), which is a consortium of financial institutions and companies responsible for all the activities that are foreseen in the agreement, including the coordination of financing and service delivery. A graphic representation of our definition of a PPP is shown in figure 2.1.

Figure 2.1: A definition for Public-Private Partnerships

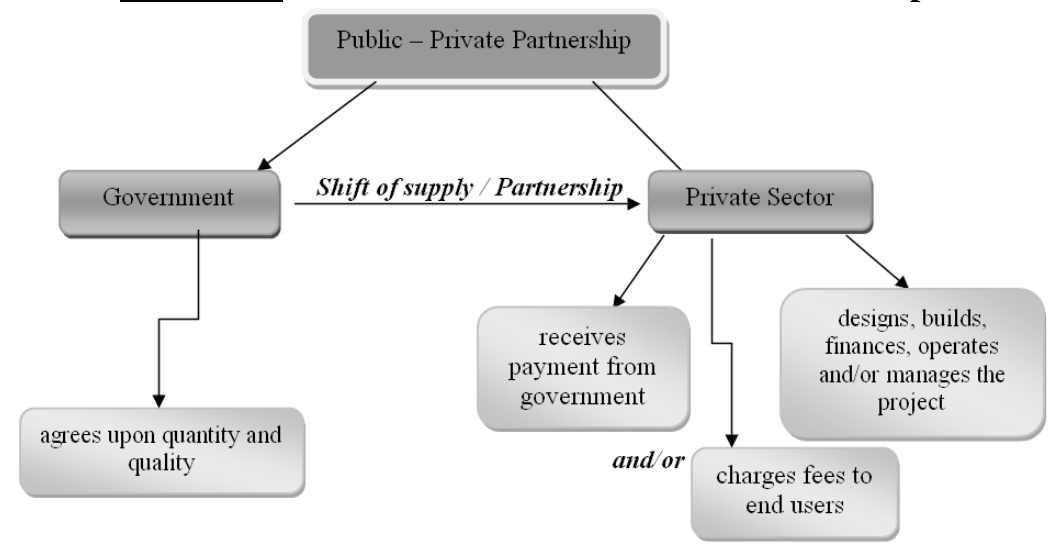

Source: $O E C D, 2008$

A frequent confusion in the literature regarding definitions is that between a concession and a PPP and whether the first constitutes the second. For example, the World Bank includes concessions in its PPP database; thus, there can be an overlap of definitions. Concessions and PPPs have many common features, in that both "use" the private partner to improve efficiency and to manage better infrastructure investment and services delivery. They also both implement the risk transfer to the private partner as the basic feature for these goals, since they involve the operation, maintenance and financing of the project from the private 
partner(s). In some of the PPPs, another common factor is that, after the end of the project, the asset is transferred back to the government.

This raises the question as to what could actually distinguish PPPs and concessions. Even though both require adequate risk transfer to the private partner, the level of risk transfer is substantially higher towards the concessionaire than the private partner in the PPP. This is the basic characteristic that differentiates the two schemes. Furthermore, there are other contractual technicalities that could distinguish concessions and PPPs. Concessions usually depend upon the relevant payments from the end users for the majority of the income; these user charges do not usually take the form of government payments. Either could be the case for a PPP. In some occasions, it is the concessionaire that may be required to pay the concession-granting authority for the right to operate and utilize the asset. Finally, in all concession contracts, the asset - that is transferred to the government at the end of the concession period - remains legal property of the government, even though the private partner can operate, manage and maintain it (while generating income from the asset). This settles the fiscal and accounting treatment of the concession contracts, while for the PPPs, a proper accounting management in the national accounts on an international basis still remains a complex and difficult challenge.

\subsubsection{Public-private partnership schemes}

A PPP can take various forms, in terms of how the investment project is designed and applied (IMF, 2004b):

Group A: The basic format of a PPP is a DBFO scheme, where the private actor designs, builds, finances and operates a project and then delivers the service either directly to the government or indirectly to end users. The private partner is not obliged to transfer the asset back to the government. DBFOs can have variations such as DBOs (design, build, operate), BOOs (build, own, operate), BMOs (build, maintain own), BDOs (build, develop, operate) and DCMFs (design, construct, manage, finance). 
Group B: A second general scheme includes the purchase or lease of an existing government asset by a private actor, who then manages, operates and upgrades it, without the obligation to transfer it back to the government. The basic difference from group $\mathrm{A}$ is that, in this case, the private partner buys or leases an existing infrastructure asset from the public sector. This can take the form of a BBO (buy, build, operate), an LOO (lease, own, operate), an LDO (lease, develop, operate) or a WAA (wrap-around addition). ${ }^{10}$

Group C: Lastly, the private partner(s) can design, build, lease, operate and manage the government asset and then transfer it back to the government at the end of the concession period, or at some other time predetermined by the contract; this is the basic variation from the two other groups. The modality can again take several schemes such as, BOT (build, operate, transfer), BOOT (build, own, operate, transfer), BROT (build, rent, own, transfer), BLOT (build, lease, operate, transfer), BTO (build, transfer, operate). Figure 2.2 shows the different PPP schemes.

Figure 2.2: Forms of Public-Private Partnerships

\begin{tabular}{|c|c|}
\hline PPP Group & Aims \\
\hline \multirow{3}{*}{$\begin{array}{c}\text { Group A: DBFO schemes, the private actor } \\
\text { designs, builds, finances and operates an asset }\end{array}$} & DBO (design, build, operate) \\
\cline { 2 - 2 } & BOO (build, own, operate) \\
\cline { 2 - 2 } Group B: purchase or lease of an existing & BDO (build, develop, operate) \\
\cline { 2 - 2 } government asset by the private partner who & DCMFs (design, construct, manage, finance) \\
\cline { 2 - 2 } manages, operates and upgrades it without the & BBO (buy, build, operate) \\
\cline { 2 - 2 } obligation to transfer it back to the government & LOO (lease, own, operate) \\
\cline { 2 - 2 } Group C: private partner designs, builds, & LDO (lease, develop, operate) \\
\cline { 2 - 2 } leases, operates and manages the asset and then & BOA (wrap-around addition) \\
\cline { 2 - 2 } transfers it back to the government & BOT (build, operate, transfer) \\
\cline { 2 - 2 } & BLOT (build, rent, own, transfer) \\
\cline { 2 - 2 } Source: $O E C D$, 2008. & BTO (build, transfer, operate) \\
\cline { 2 - 2 } &
\end{tabular}

\footnotetext{
${ }^{10}$ In this case the government owns a facility which is deemed to be expanded by the private actor who also operates the facility.
} 
Each element of a project (building, leasing, operating, etc.) contains risk. Hence, one way to further characterize the different groups of PPPs is by considering the risks in each type of PPP.

\subsection{Public-private partnerships and the government budget}

A public-private partnership initiative imposes a different approach, compared with the case when the government itself invests in producing a good or a service, and finances this investment through government revenues such as taxation, or via government borrowing. The direct impact on the government's budget (its revenues, its expenditures and its debt) affects many important fiscal policy decisions. The two most important factors reflecting this effect are the time horizon and the classification of the PPP project as either government expenditure or public investment.

\subsubsection{Typical public investment versus a public-private partnership}

In general, affordability of a public investment project concerns the inclusion of this project within the intertemporal governmental budget constraint. For traditional public investment schemes, cash flow and/or balance sheet treatment is twofold. As far as expenditures are concerned, capital expenditure is needed to create the asset that is necessary for the provision of the service. Current expenditure on the other hand occurs in two formats: operating and maintenance costs and interest expenses on loans that were needed to finance the project. Revenues consist of tax and user charges or fees if applicable. On these terms, if for example a project is financed via debt, even though public debt increased, the net worth and the fiscal sustainability conditions of the government may remain unaffected due to the creation of the asset itself.

This is not the case though for a PPP project. Since the private operator is accountable for the start-up capital expenditure of the project, the present capital expenditure of the government remains unaffected. So the overall capital 
expenditure for the government will be lower compared to typical public procurement - since the PPP does not affect it while that of the private sector will be higher. However, the government may be obliged to pay the operator a fee under the PPP contract, or be contractually committed to purchase a predetermined quantity for the specific project or service, thus increasing its current expenditure in the future. The private partner will use this income to pay for operating costs and interest expenses, or to repay the debt. Alternatively, the private partner can charge fees to end users or combine user fees with government payments. If the government does pay its private partners, the effect in the short-run will be a reduction in the total government capital expenditure and in the budget deficit (or an increase in the budget surplus), than if it had financed the investment itself. However, the effect should be considered for a broader time horizon, covering the whole lifetime of the PPP asset. In such a case, the effects on government expenditure and public debt are more complex and need to be further scrutinized. In the usual case that the government pays the private partner according to the specifications of the contract, this constitutes a future obligation by the government, as long as the private partner fulfills its part of the contract.

\subsubsection{Implications for fiscal sustainability and government balance effects}

The reduction in the government capital expenditure in the period of the commencement of the PPP project, will improve the primary balance ${ }^{11}$ for this period, improving debt sustainability indicators such as the public debt to GDP ratio. The debt sustainability position of the government will seem improved; however there is a tricky caveat. Even if the primary balance is improved for the time being, the capital expenditure is transformed to future current expenditure, spread over the forthcoming periods. Additional assessments are imperative to observe this future long-term effect on the

11 Primary balance is capital expenditure plus non-interest current expenditure less revenues. 
budget deficit and respectively the public debt to GDP ratio. It is obvious that the government will seek ways to cover its future primary balance outflows. The political decision on this will definitely affect other important fiscal indicators. If the government borrows to finance the prospective payments, the public debt to GDP ratio will deteriorate in the ensuing years during the concession period. In this case the effect will be similar to what would happen if the government were to borrow in order to finance the investment itself, and produce the good or service. If the government finances the deficit in a conventional way, by increasing revenues through increased taxation, the public debt to GDP ratio will remain at then same level as when the PPP started, with all the social and political consequences that may prevail under this fiscal policy decision.

The short-run effect of PPPs is a reduction of the total government expenditure and the budget deficit following the reduction in the capital expenditure. It is obvious, however that the long-run effect of the future cash (out)flows must be taken into consideration when assessing debt sustainability. Whether the PPP will then result in the project being financed at lower cost depends on the distribution of interest expenses over time and the relative level of efficiency with which the project is executed. ${ }^{12}$ If efficiency gains in terms of value for money are greater in the case of PPP than the traditional public procurement, then the project may be affordable for the intertemporal public budget. Consequently, a PPP can be preferred to the typical public investment if the comparative assessment in both cases results in an improved net present value of future revenues minus future expenditure cash flows for the PPP.

It can be the case though that an incentive to commence a PPP project can indeed exist, even if the PPP

\footnotetext{
${ }^{12}$ Interest will be paid from the private partner in the case of PPP and from the public authority in the case of typical public investment. It is more likely that interest will be more costly in the case of the PPP private partner.
} 
appears to be budgetary non-affordable. ${ }^{13}$ This is a serious concern since the "off the book" nature of PPP accounting can drive government departments to use PPPs for the wrong reason. If a government entity decides to implement a PPP even though it exceeds its allocated budget, it may not be able to make future payments to the private partner without exceeding its future allocated budgets. This can be overturned if the PPP payments are made in the form of fees by end users who access the service; then the project could fit in the budget constraint.

\subsection{Risk allocation}

\subsubsection{Risk management implications}

Following the previous discussion on the significant fiscal effect of guarantees as contingent liabilities arising from PPP contracts, it is clear that the proper allocation of PPP risk must be a high priority for the government. Efficient risk management implies that the risk should be allocated to the party best able to manage it. According to Leiringer (2006), this simplification raises issues by itself, regarding the allocation of the risk after or before the unexpected event occurs. Consequently, we need to define "the party who can better manage risk." Following the definition from Corner (2006), a risk manager manages the risk at the least possible cost and minimizes future long-term cost of the PPP project. If the cost that is associated with the prevention of the unexpected event is less than the cost of dealing with the unexpected event after it occurs, then the risk is allocated to the party who can best manage the probability of occurrence (either the private or the public partner in the PPP). Of course this does not mean that most risk is transferred to the private party. All the discussion is concentrated around the optimal amount of risk allocated to each partner. This depends on particularities and special clauses that may be different in every PPP contract. Depending on the type of the PPP project,

\footnotetext{
${ }^{13}$ This holds especially for budgets of specific governmental departments or of regional and local governments.
} 
different risk allocation methodologies can be devoted to different PPP schemes. In any case, the efficiency of the PPP project is a positive, yet a declining function of the optimal amount of risk. $^{14}$

\subsubsection{Risk types}

The OECD (2008) categorizes a number of risks that must be allocated in a PPP.

First, there is demand risk. Demand risk relates to the change of tastes, preferences and income patterns of the consumers, the existence of substitute products and the relevant competition, demographic changes and other factors that can influence the demand for the product or service, produced through the PPP.

Second, there is supply risk. Supply risk relates to the production, to the input capacity and the relevant costs, to the delivery ability, and to technology risks. It constitutes: a) availability risk, which concerns the contractually agreed delivery of the PPP product, b) construction risk, which refers to build and design delays and budget overruns and c) performance risk, dealing with the quality of the product provided and the obligation to meet the safety or public certification standards.

Third, there is financial risk. Financial risk occurs because of the changeability of financial market variables, such as the interest rates and the cost of capital, the exchange rates, inflation rates and any other factor that can influence financial market determinants.

Fourth, there are miscellaneous risks. These are other types of risk that appear in PPP contracts. Examples include: legal and administrative risks relating to the legal framework and the administration of the agreement; political risks with issues such as political stability, regulatory structure, fiscal policy etc.; residual value risk relating to the future residual value of the PPP asset, which is designed and built; default risk associated with the possibility of bankruptcy.

\footnotetext{
${ }^{14}$ Measured, for example, as standard deviations. For a further discussion
} on optimal risk allocation and efficiency see Corner 2006. 
Since the range of PPP risks is so wide, their management and diversification is very important for government officials when entering into a PPP agreement. In many of the above cases, there is pressure from the private party to leverage specific types of risks towards the public party; there are even risks that only the government can manage, such as the political risk. Such commitments from the government's side definitely raise issues of contingent liabilities arising from PPPs, which should be seriously considered for fiscal policy analysis. Nonetheless risk transfer still remains highly debatable, not only due to its complexity, but also because of the lack of a standardized procedure to assess the accounting and reporting of PPP contracts.

\subsubsection{Allocating private and public sector risk}

The realization of PPPs over a wide range of investment projects, with different provisions and characteristics, increases the variability of the specific risks that must be foreseen in a clear and transparent way when formulating the PPP contract. In this framework, each contractor bears the risk that it can manage more efficiently than the other parties involved (OECD, 2008).

The private contractors undertake risk that is related to financing, constructing and providing infrastructure services. In other words, they manage the financial risk and the supply risk. The investment can be repaid either by the public contracting authority or by the end users. Either way, concessionary payments should only be made once the project is operational, and are directly linked with the performance of the offered services, which the private sector must maintain up to certain quality standards, until the very last day of the contract. Low services must result in lower payments. The construction risk in particular is more efficiently managed by the private partner. $\mathrm{He}$ is responsible for managing possible construction discrepancies, mismanagements and subsequent debt renegotiations. Moreover, availability and performance risk are also deemed to be borne by the private contractors. They are accountable for the delivery of a specific quality and 
quantity of services, products or assets according to the contractual provisions.

Concerning availability risk, the continuous availability of the PPP product remains the main concern of the private partner, independently of the number of end users. Finally, the financial risk is better managed by the special purpose vehicles (SPVs), i.e., banks or other intermediaries that finance the PPP project. In most cases where the project is not financed via state funding, provisions for covering the financial risks are foreseen in multilateral agreements between the partners. The funding availability must be ensured to fulfil all the necessary contractual obligations from the private partner(s) in a clear and transparent way. In terms of efficiency, however, it can be the case that the net benefit is greater for the case of public procurement, since the cost of capital is greater for the private partner than the public partner.

The public partner usually bears all the other risks associated with the PPP, such as the demand risk, legal risks, political risks and residual value risks. Demand risk is usually very hard to be forecasted from the beginning. In the cases of new market trends, technological evolution or excess demand, demand risk must be managed by the contracting authority (public partner). However, if there are other reasons for lower demand than expected (such as an inadequate quality level), then the relevant risk must be managed by the private partner.

Legal risks are also to be borne by the public partner. For example, the state should grant the private partner with an extension according to the initial work plan, if there are delays on the issuance of licences for the project, or if parallel public projects that are imperative to complete the PPP product, are delayed with a responsibility from a public authority or a public corporation. In such cases the private actor can even request a compensation for its loss. If there are delays, the private actor can again request extensions or settlements for financial, construction or administrative costs. ${ }^{15}$

\footnotetext{
${ }^{15}$ A substantial part of the PPP contract is the necessary studies or reports regarding environmental issues. This must be an obligation by the public partner. If additional conditions or clauses are requested concerning
} 


\subsubsection{Risk transfer analysis}

Contracting parties can perform a horizontal analysis of the risk transfer depending on the different types of PPP projects (OECD, 2008). The level of risk transfer is directly correlated to the activities, which are responsibility of either the public or the private partner. Furthermore, the possibility of the transfer of the asset back to the state after the end of the construction period straightforwardly determines the residual value risk and presupposes a greater level of risk transferred to the public partner. For example, simple Design-Built PPP schemes require minimum risk transfer to the private partner, since he is only responsible for designing and constructing the asset assuming only the construction risk. PPP projects that are included in Group $\mathrm{C}$ as described before, such as, BOT (build, operate, transfer), BOOT (build, own, operate, transfer), BROT (build, rent, own, transfer), BLOT (build, lease, operate, transfer), BTO (built, transfer, operate) foresee the transfer of the asset back to the government. In such agreements the risk level of the private partner increases compared to simple design and built projects. The reason is that the special purpose vehicle of the partnership additionally has to finance the construction, maintenance or operation of the project and as such to assume most - if not all - of the financial risk associated with the project. However, since the PPP asset is returned to the government after the end of the period the government bears the residual value risk. Even so, the amount of risk transferred to the private sector substantially increases.

DBFO schemes such as DBOs (design, build, operate), BOOs (build, own, operate), BMOs (build, maintain, own), BDOs (build, develop, operate) with no obligation of switching the asset back to the government, requires an even greater amount of risk towards the private sector. Apart from

environmental matters, then the state should recompense the private partner for every additional cost or expense that relates to this new provision. Finally, one of the most important terms in the PPP contract concerns the prompt act and conclusion of all the necessary land expropriations. 
the supply risk and from the financial risk, also the residual value risk is transferred to the private partner. This is because he will own the PPP asset after the completion of the project. Finally, the last and maximum level of risk transfer to the private partner occurs through concessionary agreements, should we consider concessions as a form of PPP. In such cases, the private partner takes on full responsibility to finance, built and operate assuming all the relevant supply, financial, residual value or default risk, even the demand risk. The government may assume no risks at all, or in most of the cases it bears political, legal or administrative risks.

Another distinction of risk allocation among PPP partners can be made according to the controllability of the risk. By definition, risks that cannot be controlled under any circumstances are called exogenous risks, as opposed to endogenous risks (OECD, 2008). The majority of PPP risks as described in this study are considered endogenous risks. Examples of exogenous risks could be political conditions, special administrative and legal occurrences or extraordinary events such as natural disasters or terrorist attacks. Most usually, exogenous risks are borne by the government. There can be the case that an amount of risk could be transferred to the private partner, which usually presumes a premium as compensation. However, given that the risk is exogenous, the government could not expect a better management from the private actor, compared to the case that it would manage and handle the risk itself. Since the state can absorb these particular externalities better than the private party, following our initial allegation, we can presume that it can anticipate them at a lower opportunity cost for the PPP project.

\subsubsection{Demand risk, competition and externalities}

We consider demand risk as a serious determinant of efficient risk allocation. In particular, the level of competition is a key factor to ensure the optimal level of risk transfer and more specifically the allocation of demand risk. Competition in a PPP contract can be twofold: in the pre-contract phase and in the post-contract phase. In the pre-contract phase we refer 
to competition that should take place in the bidding process, the so called "competition for the market." If there are several bidders in the bidding process, potential private partners are likely to be very efficient in their project designs. On the other hand, a few bidders ${ }^{16}$ could undermine the tender process and increase the danger of opportunistic (and monopolistic) behavior by the bidders (Zitron, 2006).

The most interesting discussion though concerns the post-contract phase, or the "competition in the market." If competition in the market (of the PPP product) does not exist ex post, then the government may be brought in the underdog position of a monopolistic situation created by the private partner. For example, if latter is the only provider of the PPP good or service, and the market model turns out to be a monopoly, then the demand that the partner faces is the total demand of the market with all the respective implications. The monopolist can be the price maker with extensive market control and can direct the output of the entire industry. Furthermore, he can produce goods and services that do not comply with what people want and consequently do not align with the prevailing demand. Under competitive markets however, the consumer (potentially the government) can pick a competitor whose substitute has a quality and price, which optimally matches with his individual demand. This consumer power enhances the need of the private partner involved in the PPP to manage demand risk more efficiently, along with the goal of profit maximization. A single potential partner though could take advantage of his monopolistic position, push the demand risk towards the public partner and, thus, reduce efficiency in the risk allocation for the PPP product.

The PPP tender procedure itself can result in monopolistic situations, with immediate negative efficiency effects for the project. When the preferred bidder is announced, the unsuccessful bidders may leave the market, thus creating a monopoly. This is a usual situation in the cases of sizeable infrastructure projects where the markets are not very deep and the suppliers only a few. A monopolist has also

${ }^{16}$ Less than three according to Zitron (2006). 
greater power in renegotiating the contract compared to a competitive market. PPP contracts, due to their long-term nature, are likely to be renegotiated at some time during their lifetime. In such a case the negotiation with a monopolist leads to uncompetitive pricing and ineffective allocation of, primarily, the demand risk towards the public partner. The lack of competition undermines optimal transfer of risk and reduces the value for money for the investment compared to typical public procurement schemes. Competition can ensure effective risk allocation and increased efficiency for the PPP product.

Another aspect concerns the variations of the good or the service provided through a PPP and the externalities that arise from the nature of the PPP product. The product may be categorized as a private good without externalities or a general interest public good with externalities (OECD, 2008). This has a direct effect on the allocation of demand risk. Public goods suffer from the so called "free-rider" problem. This refers to the situation, which leads to an extensive use of a common property resource where no one person can be excluded from taking advantage of the public good or service. The free-rider may refuse or avoid paying for the relevant provisions. In such cases demand is not fully revealed and it becomes difficult, especially for the private partner, to estimate the future market demand for the product. It is obvious that the allocation of demand risk is much more complex. In such cases, a solution for the government could be to estimate the full social demand of the public good and state to the private partner the amount that it wants to be delivered. In this case, the government fully assumes demand risk, since the private partner may request demand guarantees to enter in the PPP agreement. This is also the case for the construction of a new infrastructure, when, even though there are no demand guarantees, the government has to ensure that the new infrastructure will operate and be used effectively. The government can significantly lower the demand risk it now runs, by adjusting the user charge paid to the private operator to ensure a higher level of delivery. In this 
case the respective demand risk is transferred towards the public partner.

The service that is delivered through a PPP is also determined by the level of its importance to the public interest. If the service is indeed very significant and must be delivered at all costs, then the government does not want to run the risk of a failure of the private partner to deliver the service. These services are deemed to have an inelastic social demand. Effective risk transfer in such a case is undermined if the private partner is aware of this inelasticity and the importance of the service delivery, since he presumes somehow that the government will undertake numerous risks and bail out the project in the case of bankruptcy. This means that the government fully assumes the default risk, the possibility of bankruptcy of the partnership. The moral hazard situation that is then created prevents the optimal risk transfer to the private partner. A solution to this problem concerns contractual incentives to the special purpose vehicle that finances the partnership, either to assist the operator reverse the failure or to replace the operator so as to complete the PPP project. This extra flexibility, which can be foreseen by the contract allows for a more efficient risk transfer towards the private consortium. ${ }^{17}$

\subsection{Government guarantees as contingent liabilities}

We already mentioned the contractual provisions, in many public-private partnerships, where the government has a specific obligation, for example, to purchase the service or

\footnotetext{
${ }^{17}$ Closely related to goods with inelastic social demand, are infrastructure projects that are considered basic functions of central governments, in sectors such as defense, security, law, or public administration (OECD, 2008). Even though a private operator cannot deliver services such as national security, issuance of public documents or judgment in criminal law, it may still be contracted to construct buildings for a police headquarter, a prison, a court of justice or develop a network for egovernment services. All these subsidiary services around central government functions are significantly prioritized and are treated akin to public services with inelastic social demand when implemented via a PPP scheme.
} 
product from the private operator. This is a typical occasion of transferring demand risk from the private partner to the government. The future payments of these purchases should be transparently accounted and reported, since they have significant fiscal implications. However, it is still questionable, if these payments should be counted as a liability or not. If the service is not delivered according to its contractual provisions, then the payments may not occur and therefore are considered contingent. Yet, this being the case, these government liabilities for future payments restrict future fiscal flexibility and jeopardize fiscal sustainability, even if they are classified as contingent. Furthermore, the present value of the net payments, discounted using a risk-free rate, should be included in the government debt analysis assessments.

Public-private partnerships therefore often incorporate explicit contingent liabilities. A government guarantee, which is a common feature of a PPP contract, obliges a government to take up an obligation, should a specific event occur. Government guarantees in the form of loan guarantees, minimum revenues from services, or ensuring a minimum level of demand, are a major source of fiscal risk since they give rise to an explicit contingent liability. ${ }^{18}$ The problem seems more intense, when the country is already in a poor fiscal condition. The accounting and reporting treatment of government guarantees still remains a challenge, since their contingent nature makes their valuation difficult.

Therefore, in the next chapter, we focus on the role of contingent claims in PPPs. As is clear from our discussion in this chapter, an analysis of a PPP must contain a number of elements. One element is a review of the types of risks involved in the PPP. A second element concerns the allocation of these risks. A third element, highlighted in the above, concerns the proper valuation of the risks involved, as this will ensure that government guarantees strike a balance between making the PPP financially viable, without creating the wrong

\footnotetext{
${ }^{18}$ They are characterized as explicit because they arise from a contractual agreement.
} 
incentives for the private and/or the public party. In the next chapter, we focus on this last element of PPPs, when we assess a typical case of an infrastructure PPP, where contingent claims play an important role. 


\section{Valuing public-private partnership risk: a scenario analysis}

\subsection{Introduction}

In the previous chapter, we discussed the intricacies of PPP valuation. We observed the importance of allocating each of the risks in a project to the partner that can manage that risk most efficiently. Importantly, we also emphasized the role of contingencies in PPP contracts. From a public policy perspective, in order to ensure that each party involved in the PPP has - and maintains - the right incentives, the PPP contract should try to stipulate to the best possible extent the rights and claims involved in different outcomes of the project undertaken.

In this chapter, we continue this line of thought. However, we broaden the scope, by showing that the notion of a PPP as a (set of) contingent claim(s) can also be used to value the PPP. Taking a finance perspective, we can refer to more traditional cases of the valuation of assets and derivatives products and apply them to a PPP.

Valuing contingent claims in this manner is important, as it allows us to compare more carefully different set-ups of a PPP. We demonstrate this using data from PPPs that were successfully implemented in Chile for developing transportation infrastructure. More specifically, PPPs were introduced by the Chilean government in the early and mid 1990 s in an attempt to attract private capital to support infrastructure investment. The administration realized a concessions program to finance highways of over 2.000 kilometers with a total investment of US $\$ 3,3$ billion (GomezLobo and Hinojosa, 2000).

In this chapter, we introduce and analyze the different scenarios that were at the Chilean government's disposal for executing the infrastructure project. We value the investment in each scenario, and - using common statistical techniques arrive at a cost comparison of each set-up.

The remainder of this chapter continues as follows. First, in section 3.2, we introduce the details of the Chilean 
PPP program by describing the infrastructure projects themselves. Next, in section 3.3, we discuss the role of minimum revenue guarantees as part of the PPP and we describe the Chilean government's debt situation and fiscal balances. Section 3.4 includes the Monte Carlo simulation, the t-tests for revenues/guarantees and assets/debt and the viewpoint of a government bond (including the net contingent flows) as a call option. In section 3.5, we introduce the different scenarios along which the PPP could have been carried out and, finally, section 3.6 concludes.

\subsection{The Chilean case}

The Chilean PPP experience was chosen because of several reasons. First of all, the size and magnitude of the concessions program constituted the largest part of the overall public investment program and a substantial portion of fiscal variables for the years in question, such as the deficit/surplus and the gross domestic product. The program is therefore very influential when assessing the impact on the national accounts. Furthermore, the Chilean PPP scheme was very successful in terms of on-time design and construction development, cost budget accuracy and flexibility when encountering ex post problems such as expropriations and the like. Reasons for this success were the program's straightforward regulatory framework, the concrete concession structure, the clear bidding process and the steady financing, which resulted mainly via toll revenue and was "insured" by transparent government guarantee provisions. Finally, the validity and reliability of the data of the Chilean concession program was a decisive feature in choosing this case study.

Even though most of the data were retrieved on an informal basis and the bulk of information is still confidential, the ministry of public works provides a substantial data set on the program, which includes quotes on the initial investment costs, good estimations of the average daily traffic using traffic projection models and specific construction features for each route section such as the length of the road and the duration of the contract. The complexity of the program, the 
innovative features that were included in the tender procedure and the contract preparations, such as the minimum revenue guarantees and the revenue sharing schemes, makes the development of the scenarios a more challenging task.

We proceed with the brief description of the representative PPP projects. Almost $75 \%$ of the total volume that was invested through the concessions program refers to the main north-south Pan American highway, also known as "Route 5." More specifically, the data include the southern part of the route, which is divided in eight sections and is, in total, about 1.500 kilometres long. All the projects are in full operation and were chosen according to their overall impact in terms of the magnitude of initial investment.

Table 3.1: Route 5 Projects Data

\begin{tabular}{|c|c|c|c|c|c|c|}
\hline $\begin{array}{c}\text { Projects, } \\
\text { Route 5 }\end{array}$ & $\begin{array}{c}\text { Year } \\
\text { concession } \\
\text { awarded }\end{array}$ & $\begin{array}{c}\text { Year of } \\
\text { operation }\end{array}$ & $\begin{array}{c}\text { Investment } \\
\text { in million } \\
\text { CH\$ }\end{array}$ & $\begin{array}{c}\text { Length } \\
\text { in km }\end{array}$ & $\begin{array}{c}\text { Estimated } \\
\text { average daily } \\
\text { traffic }\end{array}$ & $\begin{array}{c}\text { Duration } \\
\text { in years }\end{array}$ \\
\hline $\begin{array}{c}\text { Talca - } \\
\text { Chillan }\end{array}$ & 1995 & 1998 & 72.609 & 192 & 9.000 & 10 \\
\hline $\begin{array}{c}\text { Santiago - } \\
\text { Los Vilos }\end{array}$ & 1996 & 1999 & 112.136 & 218 & 9.200 & 23 \\
\hline $\begin{array}{c}\text { La Serena - } \\
\text { Los Vilos }\end{array}$ & 1996 & 2000 & 109.250 & 228 & 2.500 & 25 \\
\hline $\begin{array}{c}\text { Chillan - } \\
\text { Collipulli }\end{array}$ & 1997 & 2001 & 93.924 & 160 & 5.900 & 22 \\
\hline $\begin{array}{c}\text { Temuco - } \\
\text { Rio Bueno }\end{array}$ & 1997 & 2001 & 85.119 & 172 & 3.500 & 25 \\
\hline $\begin{array}{c}\text { Rio Bueno } \\
\text { - Puerto } \\
\text { Montt }\end{array}$ & 1997 & 2001 & 88.054 & 136 & 5.800 & 25 \\
\hline $\begin{array}{c}\text { Collipulli - } \\
\text { Temuco }\end{array}$ & 1997 & 2002 & 101.052 & 163 & 5.700 & 25 \\
\hline $\begin{array}{c}\text { Santiago - } \\
\text { Talca }\end{array}$ & 1998 & 2002 & 345.218 & 266 & 18.000 & 25 \\
\hline \begin{tabular}{c} 
TOTAL \\
\hline Source: Ministry of Public Works, Santiago, Chile.
\end{tabular} & $\mathbf{1 . 0 0 7 . 3 6 2}$ & $\mathbf{1 . 5 3 5}$ & $\mathbf{5 9 . 6 0 0}$ & 2 \\
\hline
\end{tabular}

The government, in the case of "Route 5," implemented a balanced toll level policy that set roughly equal tolls in all segments of the expressway. As such, we are able to use an average toll rate for our valuation. Other common features include similar investment per kilometre and mutual design parameters. Table 3.1 above summarizes all the 
projects for "Route 5," including the year that the concession was awarded, the year of operation, the initial estimated cost of the investment, ${ }^{19}$ the total length of each section in kilometres, an estimated average daily traffic and the duration of each concession. The data were provided by the ministry of public work, who also used traffic forecast models to estimate an average daily traffic for each project. Before the bidding stage, the government guarantees a total revenue level at $70 \%$ of the estimated official cost of the project for the whole duration of the concession. For simplicity, we do not consider operation and maintenance costs, since they constitute only a small portion of the overall investment for the project. Average tolls per kilometre vary between $\mathrm{CH} \$ 12$ and $\mathrm{CH} \$ 13$ for all "Route 5" projects.

\subsection{Revenue guarantees, debt portfolio and fiscal balances}

\subsubsection{Guarantees and expected revenues}

The legislature framework in Chile concerning the construction, maintenance and operation of public infrastructure via concessions foresaw flexible tender procedures, establishment of mutual rights and obligations between the private and the public partner and the use of incentives for private participation (Lorenzen, Barrientos and Babbar, 2004). More specifically, these incentives constituted subsidies and government guarantees. The guarantees concerned a minimum revenue level that was guaranteed by the government, following the exploitation of road tolls by the private partner(s). These initiatives were a decisive feature when a bank performed credit risk rating considering a loan for a transportation infrastructure project. The minimum revenue guarantee was a crucial indicator of a borrower's ability to repay a loan and a basic indicator when mitigating credit risk. These minimum revenue guarantees are the source of the demand risk that is associated with traffic projections. If

\footnotetext{
${ }^{19}$ In most of the projects the actual cost of the investment deviated from the estimated official cost.
} 
for a certain year, the revenues fall below a designated ceiling then the government has to compensate the concessionaire accordingly. The guarantee is also linked with an agreement to share revenues beyond a fixed level of traffic and is typically based on specific traffic projections.

More specifically, the Chilean government initiated the bids with a total revenue guarantee equal to $70 \%$ of the estimated official cost of the project, meaning investment, operating costs and maintenance costs. However, during the auctions, bidders were given the possibility to decide upon a time profile for the guarantee within a band contained by the bidding documents. ${ }^{20}$ Commonly, bidders chose the maximum of the band in the beginning of the concession, basically to benefit from debt arrangements with short maturities. ${ }^{21}$ The $70 \%$ of official cost was actually the constraint to the preference of the bidders about the present value of the guarantee that they chose for the contract. Each year, the concessionaire chose the discounted value of the yearly income guarantee subject to the official net present value of the concession as set by the government, in terms of initial investment, operating and maintenance costs. The discount rate was set by the bidding documents. The $70 \%$ on the official cost was chosen due to its direct link with the debt financing of the project. Debt was approximately $70 \%$ on average of the assets for the consortium of concessionaires. The respective guarantee served as a safety net for servicing the debt and as a strong incentive for special purpose vehicles to finance the infrastructure project. ${ }^{22}$

\footnotetext{
${ }^{20}$ The ceiling for this band was $80 \%-85 \%$ of expected yearly income.

${ }^{21}$ Many financial institutions forced concessionaires to bid high guarantee commitments during the first period of the concessions so as to secure the servicing of debt.

${ }^{22}$ Some concessions at the beginning of the concessions program had a physical traffic volume guarantee. We, though, focus on the minimum revenue guarantee scheme that was implemented in the following concessions, since different types of traffic (bikes, cars, trucks, buses etc.) pay different tolls. Also, in the case of airport concessions, "traffic" refers to the number of users, i.e. passengers. Since, with a minimum total traffic level, the definition and the composition of traffic affects revenue flows,
} 
In appendix 3-A (tables 2 and 4) we include the discounted values of the guarantees and the expected revenues and per year and per project. ${ }^{23}$ Even if the guarantees are generally estimated as $70 \%$ of the budgeted official cost, each bidder could tender a specific guarantee for each project that depended on the latter's duration and fell within specific boundaries. As such, the guarantees were set through the bidding process. The annual values of the guarantees were retrieved from the adjudication documents and all the forthcoming contract amendments that included the nominal estimated values of the guarantees for the total duration of each concession. Furthermore, to calculate the expected revenues, we multiply an average toll rate per kilometer of CH\$ 13 with the length in kilometers, with the estimated daily traffic, with 365 days for the year. We use this data to identify the cases when the minimum revenue guarantee would be triggered.

Table 3.2 includes all discounted values for the expected revenues and contractual guarantees for each section. $^{24}$ In any case that the expected revenue from the project is less than the guarantee that is foreseen in the adjudication contracts and their amendments, then the remaining amount must be covered by the government. In almost all cases the guarantee is triggered since the relevant amount is greater than the expected revenue. The third column of the table shows the net contingent flow for each project, as the difference between expected revenues and guarantees,

the minimum revenue seems like a more appropriate common factor to measure the government guarantee.

${ }^{23} \mathrm{We}$ discount at a $4,91 \%$ rate, which is an average of the LIBOR rate (12month maturity) for the period 1990 - 2007, and consider as base year, the year that the PPP was awarded for each project. For example, for all projects with a concession award year of 1996, the base year is 1996, for projects with a concession award year of 1997, the base year is 1997 and so on. The nominal amounts are included in tables 1 and 3 of appendix 3A.

${ }^{24}$ Table 5 in appendix 3-A shows the discounted values for the expected revenues and guarantees and the net contingent flows for each project and each year separately. 
under the condition that the guarantee is greater than the excepted revenues. This is the direct effect on the deficit and the indirect effect on the public debt. The government should consider all these net contingent flows when assessing the country's fiscal profile.

Table 3.2: Guarantees, expected revenues and net contingent flows per section for Route 5 projects, discounted values in million $\mathrm{CH}$, years 1990-2007

\begin{tabular}{|c|c|c|c|}
\hline Project & $\begin{array}{l}\text { Expected } \\
\text { Revenues }\end{array}$ & Guarantees & $\begin{array}{l}\text { Net contingent } \\
\text { flows }\end{array}$ \\
\hline Talca - Chillan & 37.455 & 89.666 & -52.211 \\
\hline Santiago - Los Vilos & 45.609 & 78.500 & -32.891 \\
\hline La Serena - Los Vilos & 15.197 & 35.714 & -20.517 \\
\hline Chillan - Collipulli & 22.519 & 37.324 & -14.805 \\
\hline Temuco - Rio Bueno & 14.358 & 29.774 & -15.416 \\
\hline Rio Bueno - Puerto Montt & 15.728 & 19.996 & -4.268 \\
\hline Collipulli - Temuco & 18.527 & 41.537 & -23.010 \\
\hline Santiago - Talca & 100.157 & 123.474 & -23.317 \\
\hline Total & 269.550 & 455.985 & -186.436 \\
\hline
\end{tabular}

\subsubsection{The government fiscal stance}

The Chilean economy has been experiencing a sustained growth between the years 1990 and 2007. Between 1990 and 2005, it expanded at an annual average rate of 5,6\%, which, according to comparisons by the International Monetary Fund (IMF), was among the highest in the world (Velasco, 2008). Table 3 in appendix 3-B shows the nominal gross domestic product (GDP) at current prices (mean: 39.901.466, standard deviation: 3.018.877), the gross consolidated debt at current prices (mean: 12.973.253, standard deviation: 21.570.770) and the debt to GDP ratio for the years 1990 - 2007.

From 1990 onwards, the government ran sustained budget surpluses, which were not interrupted until the economic contraction of 1999, when the fiscal deficit represented 1,4\% of GDP. Since 2000, fiscal results have remained in line with the government's structural surplus policy. In 2005, the fiscal surplus reached $4,7 \%$ of GDP 
(Velasco, 2008). Table 4 in appendix 3-B includes Chile's government deficit/surplus (mean for period: 1.085.206) calculated as the government revenues minus the government outlays for the period 1990-2007. We include the net contingent amounts, as calculated before, to the actual deficit/surplus of Chile to observe the real effect on the national accounts.

Table 3.3: Chilean government deficit / surplus deficit and total net contingent flows, million CH\$, years 1990-2007

\begin{tabular}{|c|c|c|c|}
\hline Year & $\begin{array}{c}\text { Chilean } \\
\text { government } \\
\text { deficit/surplus }\end{array}$ & $\begin{array}{c}\text { Total net } \\
\text { contingent } \\
\text { flow for year }\end{array}$ & $\begin{array}{c}\text { Chilean government } \\
\text { deficit/surplus including } \\
\text { net contingent flow }\end{array}$ \\
\hline $\mathbf{1 9 9 0}$ & 234.554 & 0 & 234.554 \\
\hline $\mathbf{1 9 9 1}$ & 202.020 & 0 & 202.020 \\
\hline $\mathbf{1 9 9 2}$ & 343.956 & 0 & 343.956 \\
\hline $\mathbf{1 9 9 3}$ & 273.940 & 0 & 273.940 \\
\hline $\mathbf{1 9 9 4}$ & 348.149 & 0 & 348.149 \\
\hline $\mathbf{1 9 9 5}$ & 879.878 & 0 & 879.878 \\
\hline $\mathbf{1 9 9 6}$ & 685.175 & 0 & 685.175 \\
\hline $\mathbf{1 9 9 7}$ & 709.336 & 0 & 709.336 \\
\hline $\mathbf{1 9 9 8}$ & 150.940 & 0 & 150.940 \\
\hline $\mathbf{1 9 9 9}$ & -790.491 & 0 & -790.491 \\
\hline $\mathbf{2 0 0 0}$ & -267.082 & -877 & -267.959 \\
\hline $\mathbf{2 0 0 1}$ & -232.747 & -11.615 & -244.362 \\
\hline $\mathbf{2 0 0 2}$ & -574.822 & -17.834 & -592.656 \\
\hline $\mathbf{2 0 0 3}$ & -230.470 & -22.728 & -253.198 \\
\hline $\mathbf{2 0 0 4}$ & 1.244 .460 & -26.084 & 1.218 .376 \\
\hline $\mathbf{2 0 0 5}$ & 3.021 .740 & -30.844 & 2.990 .896 \\
\hline $\mathbf{2 0 0 6}$ & 5.984 .100 & -35.921 & 5.948 .179 \\
\hline $\mathbf{2 0 0 7}$ & 7.551 .080 & -40.533 & 7.510 .547 \\
\hline Cumulative & $\mathbf{1 9 . 5 3 3 . 7 1 6}$ & -186.436 & $\mathbf{1 9 . 3 4 7 . 2 8 0}$ \\
\hline Sources: & I. Ministry of Finance Ministry of Public Works, Santiago, Chile & \\
\hline & & & \\
\hline
\end{tabular}

Table 3.3 shows the initial deficit/surplus for each year, the net contingent flow that is generated from the guarantees and the actual deficit/surplus including these contingent amounts. This is the real effect of the PPP risk which emerges from the guarantees, on the Chilean government deficit/surplus. It begins from the year 2000, when the first guarantees were implemented and reduces each 
year's surplus (or increases the deficit) by the relevant guarantee commitment towards the private partner. $^{25}$

\subsection{A financial viewpoint and statistical analyses}

\subsubsection{Monte Carlo dataset and t-test for assets and debt}

Up to this point we have directly linked the net contingent flows to the deficit/surplus of a government. If there is a surplus, then the negative contingent flows as they appear in our case study, decrease this surplus, while on the other edge they could increase a possible deficit. However, there is also an indirect link with the public debt. Our argument is that, from a finance point of view, if an investor is interested in investing in a country's government bond, and therefore cares about its debt, he should also consider these net contingent flows as a portion of the overall debt position of the country. More specifically the debt position affects the probability of default and is an important aspect for an investor's credit risk assessment when investing on government bonds. Consequently, the real probability of default hypothesis that should be tested is not Assets < Debt but Assets < Debt plus net contingent flows.

Table 3.4 shows the actual data of consolidated assets of the Chilean government and the central bank and the gross consolidated debt, which now includes the net contingent PPP flows. These flows were included in the debt for the years 2000 through 2007, when the guarantees were assumed to be triggered according to our previous analysis. ${ }^{26} \mathrm{We}$ use the Monte Carlo simulation method to generate a probability distribution for assets and debt and then perform a t-test on a

\footnotetext{
${ }^{25}$ Table 5 in appendix 3-B shows the cumulative values including the net contingent flows.

${ }^{26}$ We must acknowledge that the net contingent flows have more similarity to interest payments, than to debt obligations. They are part of current government expenditure and result in net budget surpluses or deficits. In this occasion though, we consider the discounted values of future cash flows and add it to the debt stock in order to capture an (indirect) effect from guarantee commitments, which constitute a potential contingent liability in the first place.
} 
more expanded dataset to assess the probability of default of the Chilean government as a decisive feature for investing in government bonds. This link between debt and net contingent PPP flows is even stronger if a country is in a seriously deteriorated fiscal position, which is one of the main reasons to embark on a PPP program in the first place.

Table 3.4: Chilean government consolidated assets and gross debt including net contingent flows from PPP guarantees, nominal values in million CH\$, years 1990-2007

\begin{tabular}{|c|c|c|}
\hline Year & $\begin{array}{c}\text { Consolidated Assets of } \\
\text { Central Government and } \\
\text { Central Bank }\end{array}$ & $\begin{array}{c}\text { Gross Consolidated Debt } \\
\text { including net contingent PPP } \\
\text { flows }\end{array}$ \\
\hline 1990 & 6.789 .166 & 7.268 .154 \\
\hline 1991 & 8.396 .121 & 8.290 .584 \\
\hline 1992 & 10.042 .931 & 9.329 .348 \\
\hline 1993 & 11.352 .486 & 10.245 .373 \\
\hline 1994 & 13.128 .479 & 11.482 .681 \\
\hline 1995 & 14.004 .333 & 11.406 .113 \\
\hline 1996 & 14.762 .100 & 11.636 .834 \\
\hline 1997 & 16.654 .705 & 12.966 .890 \\
\hline 1998 & 16.093 .363 & 12.510 .701 \\
\hline 1999 & 16.206 .050 & 13.261 .260 \\
\hline 2000 & 17.177 .264 & 14.679 .830 \\
\hline 2001 & 18.755 .259 & 15.922 .462 \\
\hline 2002 & 19.477 .530 & 16.838 .390 \\
\hline 2003 & 17.072 .866 & 17.060 .255 \\
\hline 2004 & 16.627 .972 & 16.701 .323 \\
\hline 2005 & 16.322 .742 & 16.162 .132 \\
\hline 2006 & 21.679 .471 & 15.095 .220 \\
\hline 2007 & 24.394 .152 & 12.474 .569 \\
\hline Sources: & $\begin{array}{l}\text { ternational Monetary Fund, Washington-DC, } \\
\text { anco Central de Chile, Santiago, Chile } \\
\text { inistry of Public Works, Santiago, Chile } \\
\text { uthor's calculations. }\end{array}$ & \\
\hline
\end{tabular}

We implement the Monte Carlo approach because our sample is relatively small in size and the simulation assists us to get more information about the sampling distribution of the net contingent PPP flows. The nature of such contingencies arising from PPP guarantees makes their valuation a complex and difficult task; that is why their financial impact is usually accounted for, when the guarantee is called. PPP guarantees, 
because of their contingent nature, can be valued using derivatives valuation techniques. In this case, the risky variable could be the toll revenue in the case of minimum revenue guarantee (which is the source of the demand risk) or the exchange rate in the case of an exchange rate guarantee (which is the source of financial risk). ${ }^{27}$

Further on, we support our assumption of the normal distribution in the data generating process via the Monte Carlo simulation. The normal distribution, by definition, concerns a probability density function, where the data tend to gather around the mean of the distribution. It describes any variable that clusters around a mean. As already mentioned, Monte Carlo simulation generates (pseudo) random numbers that cannot be distinguished from genuine random numbers. Therefore, claiming the independency between these random numbers, we can argue that this large dataset with finite mean and standard deviation will be approximately normally distributed (according to the central limit theorem). To back this up we perform normality tests for all variable databases (guarantees, expected revenues, assets, debt). ${ }^{28}$ The null hypothesis $\left(\mathrm{H}_{0}\right)$ is that the sample follows a normal distribution and the alternative $\left(\mathrm{H}_{\mathrm{a}}\right)$ that the sample does not

\footnotetext{
27 A Monte Carlo simulation of a stochastic process is a procedure for sampling random outcomes for the process (Hull, 2006). The methodology is based on the assumption that the value of a risky asset depends on the following indicators: its initial value, its mean and standard deviation and the value taken by a normally distributed random variable. The core of the method is the random number generator which produces a sequence of pseudo random numbers, which are in essence indistinguishable from sequences of genuinely random numbers, validating in this way the independence conditions of statistical tests. Assuming that an underlying risky variable (for revenues, guarantees, assets and debt) follows the geometric Brownian motion, Monte Carlo enables the value of the risky variable at time $\delta \mathrm{t}$ to be calculated by its initial value, the value at time $2 \delta \mathrm{t}$ to be calculated from the value at time $\delta$ t, and so on.

${ }^{28}$ The tests are the Shapiro-Wilk test, the Anderson-Darling test, the Lilliefors test and the Jarque-Bera test and are included in appendix 3-C. We apply them in order justify the application of the t-tests for comparing sample averages and to make the assumption on normalization more robust.
} 
follow a normal distribution. For all the tests, the computed pvalue is greater than the significance level alpha $(0,05)$ indicating that we should accept the null hypotheses that all datasets follow a normal distribution. In any case, there is a confidence band around actual values that are generated through the Monte Carlo process. This confidence band assumes normality. Thus, locally, the noise around the generated data is considered to be normally distributed, or, in other words, the measurement error is expected to follow a normal distribution.

Using the Monte Carlo dataset we perform a one-tailed $\mathrm{t}$-test with a paired two sample for means for assets and debt to assess the mean difference between the two variables. ${ }^{29}$ The null hypothesis $\left(\mathrm{H}_{0}\right)$ that is tested is that the mean difference is smaller or equal to zero - so the asset mean is smaller or equal to the debt mean - and the alternative hypothesis $\left(\mathrm{H}_{\mathrm{a}}\right)$ is that the mean difference is greater than zero, so the asset mean is greater than the debt mean. We combine this test with some descriptive statistics in order to assess a range within which the difference at a 95\% confidence level falls. The results are portrayed in box 3.1 .

The mean consolidated assets are 15.498.054 while the consolidated debt mean 12.944.962, giving a mean difference of 2.553.092. The Pearson correlation coefficient indicated a very weak positive relationship between assets and debt and the debt variance is substantially higher compared to the assets variance. ${ }^{30}$ As far as hypothesis testing is concerned, since the t-statistic is greater than the one-tail critical value of the t-test, we should reject the null hypothesis and accept the alternative that the mean difference is positive and the asset mean is greater than the debt mean. Furthermore, analysing the descriptive statistics for the mean difference, with a $95 \%$

\footnotetext{
${ }^{29}$ Histograms, summary statistics and the first observations of the Monte Carlo sumilation results are included in appendix 3-D (tables 1-4).

${ }^{30} \mathrm{We}$ also perform a t-test between debt and the net contingent flows. The Pearson correlation coefficient showed a very weak negative relationship between the variables.
} 
confidence level, the mean falls within the 2.448.209 and 2.657.975 range, which is the mean difference \pm 104.883 .

Box 3.1: One-tailed t-test for consolidated assets and consolidated debt with a $95 \%$ confidence interval, descriptive statistics t-Test: Paired Two Sample for Means / one-tailed test

\begin{tabular}{lrr|}
\hline \multicolumn{3}{c}{ t-Test: Paired Two Sample for Means / one-tailed test } \\
\hline Mean & Assets & \multicolumn{1}{c}{ Debt } \\
Variance & 15.498 .054 & 12.944 .962 \\
Observations & 19.946 .791 .279 .834 & 8.989 .324 .799 .368 \\
Pearson Correlation & 0,011 & 10.000 \\
Hypothesized Mean Difference & 0 & \\
Df & 9.999 & \\
t Stat & 47,716 & \\
t Critical one-tail & 1,645 & \\
t Critical two-tail & 1,960 & \\
\hline & & 2.553 .092 \\
Mean & & 53.506 \\
Standard Error & & 2.536 .852 \\
Median & 5.350 .635 \\
Standard Deviation & & 10.000 \\
Sample Variance & & 104.883 \\
Count & & \\
Confidence Level (95,0\%) & & \\
\hline
\end{tabular}

The above assessment also has a very important finance perspective. An investor who is willing to invest on a government bond, is concerned about the fiscal conditions of the country that issues this bond. The payoff from the bond depends on the relationship between the assets and the debt of the country. The investor, or the equity holder, makes money out of the bond if the assets (A) of the government are greater than the public debt (D), or A > D. On these terms, the probability of default (PD) is the probability of $\mathrm{A}<\mathrm{D}$. However, the equity holder should not consider this narrow definition of public debt, but also the net contingent PPP flows that indirectly affect the debt position of the country. Thus, he must include these contingent flows in the total debt of the country he invests. In this case the probability of the equity holder making money is $1-\mathrm{PD}$, where $\mathrm{PD}$ is the probability 
that $\mathrm{A}<\mathrm{D}$ plus contingent net PPP flows. For the Chilean case, even though the difference tends to get smaller due to the negative net contingent flows, yet assets are greater than debt (because Chile's fiscal position has improved during the last 20 years). A good counterfactual though would be to test a case study with a more unstable fiscal path. Then, the effect of the contingent flows will be much more influential.

This payoff towards the equity holder can also be seen as an option. More specifically, the equity holder has a call option on the residual value $(\mathrm{E})$ of the country, which is the difference between its assets and its debt plus net contingent flows (NCF). Respectively, to break even the following condition must hold:

$$
\mathrm{E}=\mathrm{A}-(\mathrm{D}+\mathrm{NCF})
$$

Hence, the investor has a long position in a call option and the counterparty this being the government, has a short position in a put option. This is displayed in the payoff matrix below, where we show the payoff for the equity holder (investor) and the debt holder (government) during the issuance of a government bond. As it can be observed from the matrix, the equity holder appears to have a long position in a call option. He profits from the bond if the difference $A-(D+N C F)$ is positive, while he loses for investing in the bond if $\mathrm{A}<$ (D+ NCF). ${ }^{31}$ The counterparty on the other hand has a short position in a put option. The payoff in the government's case is the liquidity that they "buy" by issuing the bond. If they are in a good fiscal stance and A > D + NCF, then the new bond transaction gives them a slightly positive payoff. However, if $\mathrm{A}<\mathrm{D}+\mathrm{NCF}$, then the new debt that they issue via the bond makes their fiscal condition even more deteriorated. In general, they are better off, as long as assets are greater than the debt. But focusing on the equity holder, he definitely must consider these net contingent PPP flows when assessing the effectiveness of his investment and when calculating the

\footnotetext{
${ }^{31}$ We consider here the opportunity cost of capital. The investor could profit more by investing in other financial instruments; as such he "loses" money.
} 
probability of default of the government. The real probability of default that he should test is $A<(D+N C F)$.

Figure 3.1: A government bond as an option for the equity holder (investor) and the debt holder (government)

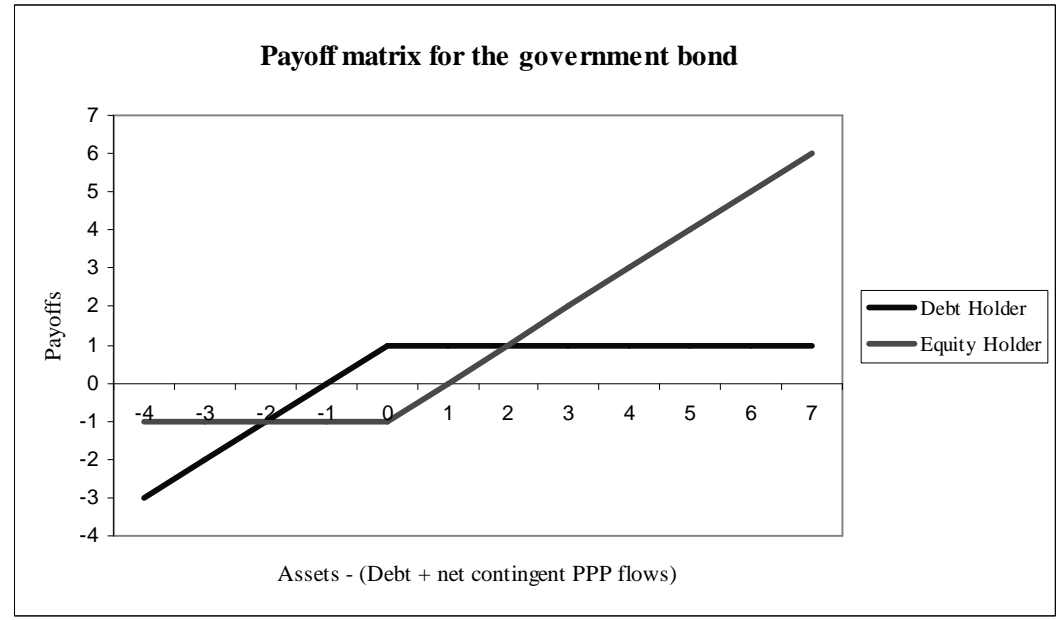

Source: Author's contribution.

\subsubsection{Monte Carlo dataset and t-test for guarantees and expected revenues}

We now proceed with the presentation of the results for guarantees and expected revenues. ${ }^{32} \mathrm{We}$ use a two-tailed paired two-sample t-test for means in order to characterize a mean difference and descriptive statistics to evaluate a specific threshold for this difference with a $95 \%$ level of confidence. The null hypothesis $\left(\mathrm{H}_{0}\right)$ is that the mean difference is zero and the alternative hypothesis $\left(\mathrm{H}_{\mathrm{a}}\right)$ is that the mean difference is other than zero. Then, via descriptive statistics, we can assess a specific range within which the mean difference between revenues and guarantees falls. Box 3.2 shows the results of the two tailed the t-test. The means significantly differ among each other and the guarantees average is higher

\footnotetext{
${ }^{32}$ In figures 3 and 4 in of appendix 3-D, we can see histograms of both datasets with 10.000 observations, as these were generated by the simulation process.
} 
than the expected revenues average giving a negative difference (revenues - guarantees).

Box 3.2: Two-tailed t-test for guarantees and expected revenues with a 95\% confidence interval, descriptive statistics

\begin{tabular}{|lr|}
\hline t-test for two independent samples / two-tailed test \\
\hline Difference & -3.274 \\
t (Observed value) & $-47,310$ \\
t (Critical value) & 1,960 \\
DF & 19.998 \\
p-value (Two-tailed) & $<0,0001$ \\
Alpha & 0,05 \\
\hline \multicolumn{2}{|c|}{ difference (revenues - guarantees) } \\
\hline Mean & -3.274 \\
Standard Error & 69,25 \\
Median & -3.232 \\
Standard Deviation & 6.925 \\
Sample Variance & 47.949 .086 \\
Count & 10.000 \\
Confidence Level $(95,0 \%)$ & 136 \\
\hline
\end{tabular}

Since the computed p-value is lower than the significance level alpha $(0,05)$ we reject the null hypothesis of the equality of the means and accept the alternative that the two means are different. The mean of this difference is -3.274 and the difference falls within -3.409 and -3.198 . This range is defined as the observed mean difference \pm 136 , which is observed at a $95 \%$ confidence level. This also verifies the actual data observations, where in most of the cases the guarantees are larger than the expected revenues resulting in negative net contingent PPP flows for the years 2000 through 2007.

\subsection{Public-private partnership risk valuation model}

This part includes the scenario analysis that contributes to the proper valuation of expected cash flows and contingencies that arise from PPP contracts. We use the data and the results from the previous sections to develop each 
scenario separately and then we conclude with a general assessment.

\subsubsection{Scenario A: Typical public investment / self-finance}

Scenario A assumes that the PPP project is de facto realized by the government without the participation of the private partner. In figure 3.2, we develop a flow chart with all the cash inflows and outflows that follow a public investment project, the three basic actors (the lenders, the government and the project's end users) and the major procedures (the operation / exploitation, the construction and the facility management). We can observe the positive and negative effects to the public debt and the fiscal accounts (capital and current account), of self-financing an infrastructure project.

Figure 3.2: Positive and negative effects in public accounts for Scenario A: Typical Public Investment / Self Finance

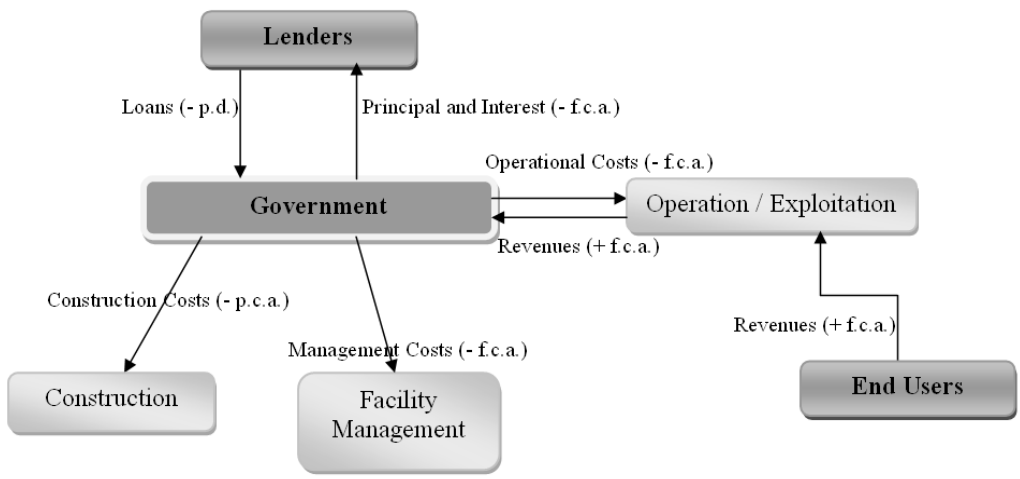

Note: p.d.: public debt, f.c.a.: future current account, p.c.a.: present capital account, +: positive effect, -: negative effect Source: Author's contribution.

There is a direct effect on the primary balance and the present capital account of the government, since the initial investment cost of the project and its prospective revenue will be included in the deficit or surplus for the years in question. This changes the deficit/surplus of the years following the initiation of the project. 
Table 3.5: Chilean government deficit/surplus, investment cost, project revenues, million CH\$, years 1990-2007

\begin{tabular}{|c|c|c|c|c|}
\hline Year & $\begin{array}{c}\text { Chilean } \\
\text { government } \\
\text { deficit/surplus }\end{array}$ & $\begin{array}{c}\text { Estimated } \\
\text { investment } \\
\text { cost }\end{array}$ & $\begin{array}{c}\text { Expected } \\
\text { project } \\
\text { revenue, } \\
\text { discounted }\end{array}$ & $\begin{array}{c}\text { Deficit/surplus } \\
\text { including the } \\
\text { project revenue } \\
\text { and cost }\end{array}$ \\
\hline $\mathbf{1 9 9 0}$ & 234.554 & 0 & 0 & 234.554 \\
\hline $\mathbf{1 9 9 1}$ & 202.020 & 0 & 0 & 202.020 \\
\hline $\mathbf{1 9 9 2}$ & 343.956 & 0 & 0 & 343.956 \\
\hline $\mathbf{1 9 9 3}$ & 273.940 & 0 & 0 & 273.940 \\
\hline $\mathbf{1 9 9 4}$ & 348.149 & 0 & 0 & 348.149 \\
\hline $\mathbf{1 9 9 5}$ & 879.878 & -72.609 & 0 & 807.269 \\
\hline $\mathbf{1 9 9 6}$ & 685.175 & -221.386 & 0 & 463.789 \\
\hline $\mathbf{1 9 9 7}$ & 709.336 & -368.149 & 0 & 341.187 \\
\hline $\mathbf{1 9 9 8}$ & 150.940 & -345.218 & 7.101 & -187.177 \\
\hline $\mathbf{1 9 9 9}$ & -790.491 & 0 & 15.011 & -775.480 \\
\hline $\mathbf{2 0 0 0}$ & -267.082 & 0 & 16.541 & -250.541 \\
\hline $\mathbf{2 0 0 1}$ & -232.747 & 0 & 24.912 & -207.835 \\
\hline $\mathbf{2 0 0 2}$ & -574.822 & 0 & 45.971 & -528.851 \\
\hline $\mathbf{2 0 0 3}$ & -230.470 & 0 & 43.820 & -186.650 \\
\hline $\mathbf{2 0 0 4}$ & 1.244 .460 & 0 & 41.769 & 1.286 .229 \\
\hline $\mathbf{2 0 0 5}$ & 3.021 .740 & 0 & 39.814 & 3.061 .554 \\
\hline $\mathbf{2 0 0 6}$ & 5.984 .100 & 0 & 37.950 & 6.022 .050 \\
\hline $\mathbf{2 0 0 7}$ & 7.551 .080 & 0 & 36.174 & 7.587 .254 \\
\hline Cumulative & $\mathbf{1 9 . 5 3 3 . 7 1 6}$ & -1.007 .362 & $\mathbf{3 0 9 . 0 6 3}$ & $\mathbf{1 8 . 8 3 5 . 4 1 7}$ \\
\hline Sources: & I. Ministry of Finance, Ministry of Public Works, Santiago, Chile & & \\
\hline & & & & \\
\hline 2. Author's calculations. & & & & \\
\hline & & 0 & 0 & \\
\hline
\end{tabular}

Table 3.5 presents the latter figures before and after the investment costs and the project revenues. ${ }^{33}$ In principle, the last column of the table shows the effect on the Chilean government deficit/surplus considering that it financed the Route 5 projects. It is the initial deficit/surplus, minus the estimated investment cost, plus the expected discounted revenue for each year. For the years 1995 through 1997 the effect on government surplus is negative; the latter decreases due to the total investment cost of seven out of the eight

\footnotetext{
${ }^{33}$ Table 1 in appendix 3-B shows the cumulative values of the Chilean government deficit / surplus including the project costs and revenues.
} 
sections of Route 5 that initiate during that period. ${ }^{34}$ At the same time, there is no expected revenue for these years yet, to counterbalance the negative cost effect. The investment gradually starts to offset after year 1998. However, the revenue for this year is much lower than the estimated cost for the last section of Route 5. As a result, the surplus switches into a deficit under the assumption of typical public investment. For the following years up to 2007, when the government finances no project, there is either an increase in the surplus (years 2004 through 2007) or a decrease in the deficit (years 1999 through 2003) due to the expected revenues.

Consequently, from a debt sustainability point of view, public investment in Chile seems to be consistent with maintaining macroeconomic stability. The fact that the Chilean fiscal conditions are improving throughout the period enhances the affordability of such projects within the intertemporal budget constraint, not affecting (indirectly) gross debt in the short run. Public investment could increase the net worth of the government, adding up to the stock of public (physical) capital, generating additional government revenue and, most importantly, realizing important infrastructure investment with no burden in terms of extra borrowing cost. ${ }^{35}$

\subsubsection{Scenario B: public-private partnership}

The initial investment for every section of the Route 5 projects is financed by the private consortium and constitutes no burden for the government. Furthermore, the Chilean

\footnotetext{
${ }^{34}$ We assume that the year of the award of the concession to the private partner for each project, is the year that the government would cover the investment, if it were to finance the project itself.

${ }^{35}$ We should always bear in mind that the self-finance approach seems to be beneficial in an economy with good fiscal performance. A similar analysis for economies that face difficulties to maintain a sustainable fiscal path would be a good counterfactual scenario and an issue for further research. Another interesting assessment to follow is the comparison of this scheme with the scenario of implementing the infrastructure projects via public-private partnerships.
} 
government is not obliged to pay any kind of fee to the road operator, or to purchase a predetermined quantity since we are referring to infrastructure projects and not to the production of a good or a service. As a result, the present capital expenditure but also the future current expenditure of the government will not bear the burden of either the new project or future concession payments. The primary deficit will remain unaffected in this context. However, the private partner charges toll fees to end-users. These user fees are a source of revenue that would be collected by the government, raising the current government revenue.

Figure 3.3 shows the positive and negative effects on public debt and the fiscal balances, considering the PPP scenario. The new actor that is added in this flowchart compared to figure 3.2 , is the private partner who now borrows to design, construct and finance the project. The private partner undertakes the loans and is responsible for amortization and interest payments. Concurrently, he receives the project's revenue via tolls exploitation. He also bears the construction and facility management costs. Moreover, we introduce two new contingent flows for the government, the guarantees with a negative effect on the future current account and the revenue sharing flows with a positive effect on the future current account.

Figure 3.3: Positive and negative effects in public accounts for Scenario B: Public-Private Partnership (PPP)

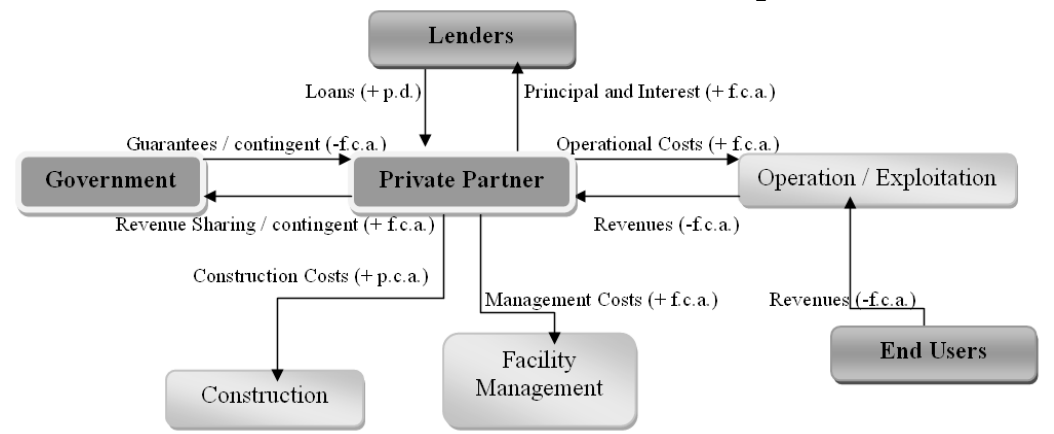

Note: p.d.: public debt, f.c.a.: future current account, p.c.a.: present capital account, +: positive effect, -: negative effect Source: Author's contribution. 
The short-run effect of the Route 5 transport infrastructure comparable to typical public investment is a reduction of the total government expenditure (sourcing from the reduction in the capital expenditure). Consequently, this will improve the primary balance for the years 1995, 1996, 1997 and 1998, when the investment took place for several sections. However, we also need to consider the effect of the future cash inflows from the toll revenue of the infrastructure, compared to the first scenario. In table 3.6, we evaluate the effect on the government deficit/surplus by cross-comparing this latter case with the typical public investment. ${ }^{36}$

Table 3.6: Chilean government deficit/surplus, Typical Public Investment vs. Public-Private Partnership, million CH\$, years 19902007

\begin{tabular}{|c|c|}
\hline Year & $\begin{array}{l}\text { Difference in deficit/surplus, } \\
\text { Typical Public Investment minus Public-Private Partnership }\end{array}$ \\
\hline 1990 & 0 \\
\hline 1991 & 0 \\
\hline 1992 & 0 \\
\hline 1993 & 0 \\
\hline 1994 & 0 \\
\hline 1995 & -72.609 \\
\hline 1996 & -221.386 \\
\hline 1997 & -368.149 \\
\hline 1998 & -338.117 \\
\hline 1999 & 15.011 \\
\hline 2000 & 16.541 \\
\hline 2001 & 24.912 \\
\hline 2002 & 45.971 \\
\hline 2003 & 43.820 \\
\hline 2004 & 41.769 \\
\hline 2005 & 39.814 \\
\hline 2006 & 37.950 \\
\hline 2007 & 36.174 \\
\hline Cumulative & -698.299 \\
\hline Sources & $\begin{array}{l}\text { 1. Ministry of Finance, Ministry of Public Works, Santiago, Chile } \\
\text { 2. Author's calculations. }\end{array}$ \\
\hline
\end{tabular}

${ }^{36}$ Table 2 of appendix 3-B shows separately the cumulative values of the Chilean government deficit / surplus in the cases of typical public investment and PPP. 
The baseline scenario is the PPP scenario. We compare the PPP scenario with the typical public investment scenario. For every year, we observe the difference between the public investment cash flows and the PPP cash flows. The minus sign indicates that the costs are greater in the case of public investment and the plus sign indicates that there is a positive net cash flow for the public investment scenario.

More specifically, for years 1995, 1996 and 1997, the initial cost of almost all of the projects for Route 5 would decrease the government surplus at a great amount, totaling around 662 billion $\mathrm{CH} \$ .^{37}$ Due to the very high cost of the last project (345 billion $\mathrm{CH} \$$ ) this difference is even greater for the next year 1998, when the fiscal condition appears to be more deteriorated, since there is a government budget deficit. This extra public funding would increase the deficit due to the high cost of the investment, while little extra revenue would be generated by a single section in operation (Talca-Chillan). From this year onwards though and as more sections would enter into operation, the government would start collecting revenues from toll exploitation, which would have a positive effect. As we can indeed observe for the period 1999-2007, the differential is positive. The effect of the highway infrastructure projects continues to be positive as long as toll revenue flows into the government budget. ${ }^{38}$ The total cumulative amount in the last line of table 3.6 shows that if the government realized the project through typical public investment, then the overall negative effect in the government balance would amount to almost 698 billion $\mathrm{CH} \$$ for the period 1990-2007. For this period, the cumulative surplus/deficit position is better if the government moves from public funding to a PPP.

\footnotetext{
${ }^{37}$ This surplus is shown in Table 3.5.

${ }^{38}$ We do not consider maintenance costs since they only constitute a very small portion of the overall estimated budget of the project.
} 


\subsubsection{Scenario C: public-private partnership with CDS / no counterparty default risk}

The valuation of the contingencies in the form of PPP guarantees is achieved using derivatives valuation techniques and more specifically the credit default swap (CDS) valuation. ${ }^{39}$ This scenario assesses the price of the guarantee without considering counterparty risk. This guarantee is directly linked to the demand risk as described at previous section, but also to the credit risk of the project. The credit default swap can serve as a tool to reduce the credit risk exposure of the government. The credit event in this case is the triggering of the minimum revenue guarantee. If the toll revenue falls behind the specific threshold that is foreseen in the PPP contract, then the government will have to activate the guarantee. However, it can buy protection against this possibility of default, by insuring via a credit default swap the contingent amount that it will reimburse the private partner. ${ }^{40}$

The present scenario with the credit default swap and the effects of the PPP on the debt and on the fiscal balances is shown in figure 3.4. Compared to the previous scenario of the plain PPP arrangement, most of the cash flows and the basic actors are the same. The four actors are the government, the private partner, the lenders and the end users, while the flows of payments concerning loans, construction and maintenance costs, revenues and the contingent flows (guarantees and the revenue sharing scheme) have the same direction. We introduce a new basic actor who issues the CDS. This is a

\footnotetext{
${ }^{39}$ Credit default swap definitions and valuation principles are included in appendix 3-F.

${ }^{40}$ The application of CDSs is not limited only to revenue guarantees. It can also be extended to other cases of government contingencies and for a wider range of PPP projects. For the simple case of a concession without minimum revenue guarantees, where most of the risk is transferred towards the private partner, the private partner can default if it fails to deliver the contractually agreed quantity of the PPP product, if there are build and design delays and budget overruns or if the quality of the product provided does not meet the safety or public certification standards. On the other edge, CDSs can also be used for the valuation of more complex guarantees such as exchange rates guarantees.
} 
financial intermediary, for example, an insurance company. There are two flows between this intermediary and the government: a cash outflow from the government - which is the purchaser of the swap - in the form of periodic payments towards the intermediary until / if the private partner defaults ${ }^{41}$ and a contingent cash inflow towards the government, the payoff in the case of the private partner default.

Figure 3.4: Positive and negative effects in public accounts for Scenarios C and D: Public-Private Partnership with credit default

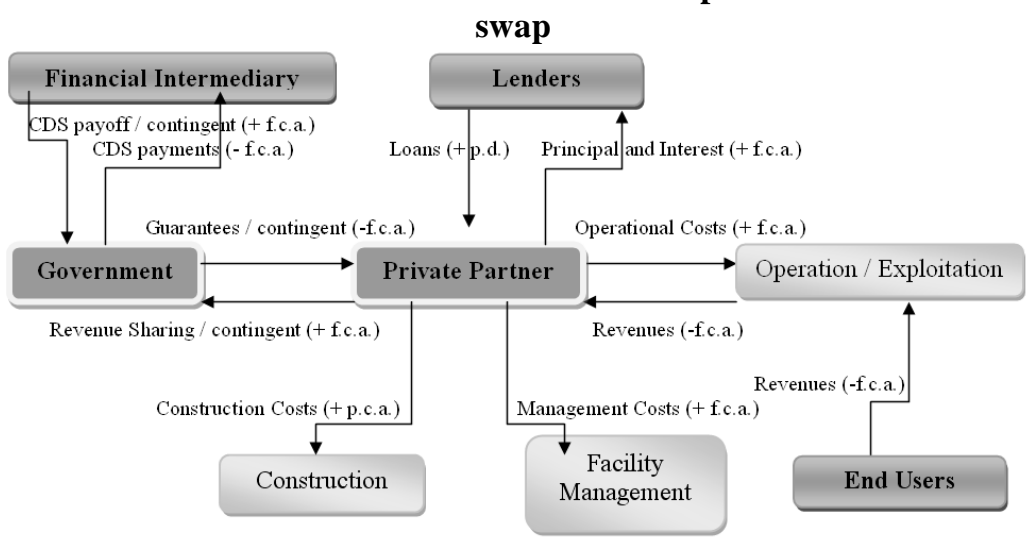

Note: p.d.: public debt, f.c.a.: future current account, p.c.a.: present capital account, +: positive effect, -: negative effect Source: Author's contribution.

To value the PPP risk via the CDS we first need to address the projects' default probabilities project. According to each project's credit ratings we calculate the unconditional default probabilities, using an average default rate. ${ }^{42}$ So, if the probability of default for the first year is $\mathrm{PD}_{1}$, then the probability of survival for that year is $1-\mathrm{PD}_{1}$, the probability of default for the second year is $\mathrm{PD}_{2}=\mathrm{PD}_{1} *\left(1-\mathrm{PD}_{1}\right)$ and the probability of survival is $1-\mathrm{PD}_{2}$ and so on. As such, we calculate all the default and survival probabilities for each PPP project from the year that the relevant guarantee is in force

${ }^{41}$ Or until the end of the PPP contract if the private partner does not default.

42 The rates and respective default probabilities were retrieved from Standard and Poor's 'Understanding Standard and Poor's Ratings Definitions" and are shown in appendix 3-E. 
until year 2007. The relevant table is included in appendix 3$\mathrm{F}^{43}$

Following the above, we move on with computing the credit default swap as the present value of the expected payoff minus the present value of the CDS payments made by the government, plus any accrual payments. ${ }^{44}$ Table 3.7 consolidates all calculations of the expected CDS payments, payoffs and accruals. In appendix 3-G (tables 1-3), we show the detailed calculations per year and per project for all the aforementioned figures.

Table 3.7: Expected CDS payments, accruals and payoffs, discounted values, Route 5 projects

\begin{tabular}{|c|c|c|c|}
\hline Project & $\begin{array}{l}\text { Expected } \\
\text { Payment }\end{array}$ & $\begin{array}{c}\text { Expected } \\
\text { Accrual }\end{array}$ & $\begin{array}{c}\text { Expected } \\
\text { Payoff } \\
\end{array}$ \\
\hline Talca - Chillan & $6,9467 \mathrm{~s}$ & $0,0100 \mathrm{~s}$ & 0,0120 \\
\hline Santiago - Los Vilos & $6,0372 \mathrm{~s}$ & $0,0480 \mathrm{~s}$ & 0,0576 \\
\hline La Serena - Los Vilos & $5,4581 \mathrm{~s}$ & $0,0191 \mathrm{~s}$ & 0,0230 \\
\hline Chillan - Collipulli & $4,7432 \mathrm{~s}$ & $0,0377 \mathrm{~s}$ & 0,0453 \\
\hline Temuco - Rio Bueno & $5,0220 \mathrm{~s}$ & $0,0008 \mathrm{~s}$ & 0,0009 \\
\hline Rio Bueno - Puerto Montt & $4,8992 \mathrm{~s}$ & $0,0172 \mathrm{~s}$ & 0,0206 \\
\hline Collipulli - Temuco & $4,1629 \mathrm{~s}$ & $0,0060 \mathrm{~s}$ & 0,0072 \\
\hline Santiago - Talca & $4,3673 \mathrm{~s}$ & $0,0063 \mathrm{~s}$ & 0,0075 \\
\hline Total & $41,6366 s$ & $0,1451 s$ & $\mathbf{0 , 1 7 4 2}$ \\
\hline
\end{tabular}

The total expected payments adding up all the reference years and projects are 41,6366s and the total accrual payments are 0,1451s. Their sum, which is $41,7817 \mathrm{~s}$ $(41,6366 \mathrm{~s}+0,1451 \mathrm{~s})$, constitutes the total CDS payments for the period in question. Total expected payoffs are 0,1742 . With these figures, we are in the position to obtain the value of

\footnotetext{
43 Appendix 3-F constitutes a detailed description of credit default swap definitions and valuation principles and a presentation of default and survival probabilities.

${ }^{44} \mathrm{We}$ assume a discount rate (LIBOR average) of $4,91 \%$, a recovery rate of $40 \%$, halfway-year defaults and yearly CDS payments. The present value of the payoff is the discounted value of the probability of default times $(1-\mathrm{R})$ for each year of the contract. The expected payments are the total of the discounted values of the probability of survival times the rate at which payments are made per year.
} 
the CDS spread, $s$, for all the projects. Equating the two amounts of payments and payoffs gives us the CDS spread: $41,7817 \mathrm{~s}=0,1742 \rightarrow \mathrm{s}=0,00417$. This means that the midmarket CDS spread should be 0,00417 times the notional principal or 41,7 basis points per year. In absolute terms, if we consider that the notional principal is the maximum amount of the guarantees that are covered via the CDS, then the mid market CDS spread is the total discounted values of the guarantees times the spread, so $459.023 * 0,00417=1.914$ million $\mathrm{CH} \${ }^{45}$ This is the price of the risk exposure for the government using the CDS spread as a measure for the guarantee valuation.

\subsubsection{Scenario D: public-private partnership with CDS / counterparty default risk}

The last scenario still uses the above valuation to price PPP guarantees and the assumption that the government insures the project via a credit default swap, but also considers the counterparty (government) default risk of the public entity. ${ }^{46}$ Both actors in the partnership are concerned with the risk of default reducing, thus, moral hazard. The assumptions are similar with the case of no counterparty default risk. ${ }^{47}$

We use credit ratings for both the reference entity and the counterparty. If the credit index for the reference entity falls below its default barrier before the credit index for the counterparty does so, payments continue up to the time of default with a final accrual payment. If the counterparty defaults first and the credit index for the counterparty falls below its default barrier before the credit index for the reference entity does so, payments continue up to the time of the default, with no final accrual payment. In the first case

\footnotetext{
${ }^{45}$ Guarantees amount to 459.023 million $\mathrm{CH} \$$. For a detailed presentation of the calculation of guarantees, refer to table 2 of appendix 3-A.

${ }^{46}$ For example, the government may not meet its contractual obligations in the form of payments or fees towards the private partner.

${ }^{47}$ We consider that default probabilities, interest rates and recovery rates are mutually independent and that the government's claim in the case of default is the face value of the corporate bond plus its accrued interest.
} 
there is a payoff while in the second case there is no payoff. If neither the counterparty nor the reference entity default, then payments continue for the life of the credit default swap and there is no payoff. ${ }^{48}$

In order to calculate the CDS spread in this case, we have to recalculate the CDS expected payments incorporating this time the default probability of the counterparty, this being the Chilean government. Since the accruals and the payoffs do not apply in the case that the counterparty defaults first, the calculation of the accruals and the payoffs are the same as computed in Scenario C previously. However, we have to recompute each expected CDS payment, taking into consideration the default probabilities of Chile. Then via discounting, we obtain a new present value of these payments containing the risk of default by the counterparty. To this extend, we use the default and survival probabilities of the Chilean government. ${ }^{49}$ Table 3.8 shows the expected payments of a CDS including the counterparty default risk. ${ }^{50}$

Table 3.8: Expected CDS payments including counterparty default, Route 5 projects

\begin{tabular}{|c|c|}
\hline Project & Expected Payment, discounted \\
\hline Talca - Chillan & $6,9291 \mathrm{~s}$ \\
\hline Santiago - Los Vilos & $6,0204 \mathrm{~s}$ \\
\hline La Serena - Los Vilos & $5,4412 \mathrm{~s}$ \\
\hline Chillan - Collipulli & $4,7273 \mathrm{~s}$ \\
\hline Temuco - Rio Bueno & $5,0049 \mathrm{~s}$ \\
\hline Rio Bueno - Puerto Montt & $4,8826 \mathrm{~s}$ \\
\hline Collipulli - Temuco & $4,1476 \mathrm{~s}$ \\
\hline Santiago - Talca & $4,3512 \mathrm{~s}$ \\
\hline Total & $41,5043 \mathrm{~s}$ \\
\hline
\end{tabular}

\footnotetext{
${ }^{48}$ Refer to appendix 3-F for a detailed description of the valuation principles for a CDS with counterparty default risk.

${ }^{49}$ These probabilities are calculated from Standard \& Poor's credit ratings and are shown in table 3 of appendix 3-F.

${ }^{50}$ Table 4 in appendix 3-G, includes all the calculations for the expected payments of a CDS, incorporating the counterparty default risk of the government.
} 
The total expected payments for this scenario is $41,5043 \mathrm{~s}$ and, given that the total accrual payments are $0,1451 \mathrm{~s}$, the total payments for the CDS with counterparty default risk is $41,5043 \mathrm{~s}+0,1451 \mathrm{~s}=41,6494 \mathrm{~s}$. Then since the total expected payoffs are 0,1742 , the CDS spread is given by: $41,6494 \mathrm{~s}=0,1742 \rightarrow \mathrm{s}=0,00418$. This means that the midmarket CDS spread should be 0,00418 times the notional principal or 41,8 basis points per year. In absolute terms, the mid market spread for a CDS with counterparty default risk is $459.023 * 0,00418=1.919$ million $\mathrm{CH} \$$. This is the actual price of the government risk, incorporating as well the counterparty's probability of default.

\subsection{The four scenarios put together}

The Chilean experience, due to the successful PPP program in terms of design, development and transparent regulation, provided us with an effective unit of analysis for the application of the scenario based model.

In Scenario A, for the initial years of the PPP program, there is a negative effect on government surplus. This is attributed to the primary investment cost of many projects and the limited concurrent revenue cash inflows (since the projects were in no or early operation). For the years to follow, when no start-up investment is financed by the government, there is either an increase in the surplus or a decrease in the deficit, due to increased PPP revenues.

Scenario B describes the actual case of the PPP, for the design, building and operation of the infrastructure. Our analysis in this case is twofold. We initially compare the PPP with typical public procurement, utilizing cash flow analysis. It is reasonable to expect that for the first years, when the majority of the projects commenced, the burden on the surplus or deficit will be less in the case of the PPP. As more projects enter into the process, the operator starts collecting revenues from exploitation, while the investment costs have already been incurred. Moreover, we introduce the aspect of net contingent flows for the PPP scenario. Since the government implements a revenue guarantee scheme, in any case that the 
expected revenue from the project is less than the guarantee that is foreseen in the adjudication documents, the remaining amount must be covered by the government. In almost all cases, the guarantee is triggered since the relevant amount is greater than the expected revenue. The calculated net contingent flows constitute the direct effect on the deficit and the indirect effect on the public debt, thus they must be considered by the government (and the investors on a financial perspective). Even though these flows weaken the fiscal position of the government, assets still remain greater than debt plus the net flows in our case study.

Finally, we determine the guarantee price (or the price of the government risk exposure) through the value of a CDS. This is the present value of the expected payoff minus the present value of the expected payments (including accruals) made by the government. The mid-market CDS spread in Scenario $\mathrm{C}$ is 1.914 million $\mathrm{CH} \$$ and, in Scenario D (considering counterparty default as well), it is 1.919 million $\mathrm{CH}$ \$. The latter gives us a slightly higher risk price. The guarantee - now covering the government's default as well - is a bit more "expensive" compared to the previous scenario with no counterparty default. ${ }^{51}$

In the section that follows, which constitutes the beginning of chapter four, we highlight the key events of the banking crisis and describe the negative effect of credit protection contracts that attributed to the expansion of systemic financial market risk. Considering this aspect of the recent crisis, we can observe how the proposed scenarios that incorporate credit protection are linked to one of the most significant determinants of the financial turmoil. Figure 3.5 summarizes our main findings of the scenario-based model that was developed in this chapter.

\footnotetext{
${ }^{51}$ The difference between scenarios $\mathrm{C}$ and $\mathrm{D}$ is minimal, since the survival probabilities for Chile are very high.
} 
Figure 3.5: Scenario-based model for PPP risk valuation

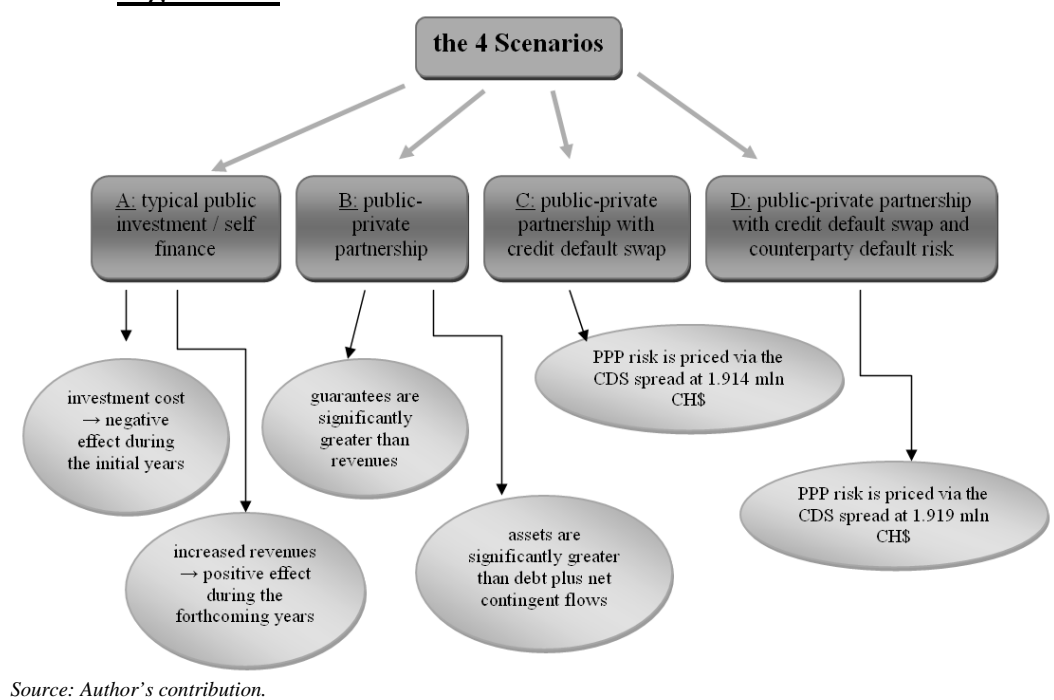

Source: Author's contribution. 


\section{The credit crisis. Private partnerships for public remedies}

\subsection{Credit crisis and banking sector interventions: an introduction}

As already discussed in the introduction of the thesis, there are specific linkages between public-private partnerships (PPPs) and banking sector interventions that were implemented by governments as crisis remedies. By definition, these interventions constitute PPPs between the public sector and private entities, namely banks and financial institutions. Crisis interventions and pure PPP projects have some common features. First, both must be evaluated in terms of costs, benefits, value for money and budget affordability. Second, there is a substantial public risk exposure. In the case of PPPs, there are issues of risk allocation among the public and the private partner, with the government bearing the risk it can manage better at the least possible cost. In many occasions, guarantees on deposits, on loan principal and interest, on potential future losses from assets or other guarantees, have been used as crisis remedies mainly to restore depositors' and investors' confidence in the banking system. All the above constitute explicit contingent liabilities for the government, with, in many cases, a sizeable government risk exposure.

A notable distinction concerning risk allocation is that, even thought the private partner may bear specific risks realizing a PPP contract, in the case of a crisis measure, a primal objective is to remove risk off the bank balance sheet. As a result, risk allocation between the public (government) and the private partner (bank) in the case of a crisis partnership is not an issue. A third common feature shared by PPPs and crisis measures is the need for efficient asset and liabilities management. As far as liabilities management is concerned, liability side guarantees and other relevant features concern both of these contractual agreements. Asset management refers to: a) the accounting treatment of the PPP product, which affects its classification in the national 
accounts and b) the purchases of distressed bank assets and provisions for futures losses for these assets as crisis remedies.

The three chapters to follow discuss several aspects of these crisis interventions through the banking system. In this chapter, we initially review the highlights of the crisis and connect its main determinants to relevant policy decisions. We also review the literature on lessons from previous crisis episodes and the overview of policy measures that were historically implemented by governments. The prime contribution of the chapter is twofold. Following a simple balance sheet approach, we address the first research question of the chapter. This concerns the categorization of all crisis interventions. We classify all measures into three different groups: asset management, liabilities management and equity management. The first group mainly consists of purchases of distressed assets, guarantees for future losses from assets (ring-fencing) and other loan loss provisions. Liabilities management includes deposit insurance protection, debt guarantees, guarantees on principal and interest and on other interbank liabilities. Finally, equity management incorporates direct equity injections, (partial) nationalization and / or mergers with public institutions and subordinated debt. Second, we use our balance sheet approach to give a "balanced" assessment of the specific goals that each different group of remedies may address and on potential risks and concerns that need to be considered, such as moral hazard, free-riding, an increased government risk profile, insolvency by increased liabilities and explicit contingencies.

The remainder of this chapter continues as follows. In section 4.2 we briefly describe the historical background of the current credit crisis and in section 4.3 the lessons that we have learned from previous crisis episodes. Section 4.4 contains an overview of current government interventions and in section 4.5, we categorize the different groups of interventions, using a balance sheet approach. Section 4.6 concludes. 


\subsection{The chronicles of the credit crisis}

\subsubsection{Reasons and roots}

After the US investment bank Bear Stearns announced - in June 2007 - that two of its hedge funds, which were based on mortgage-backed securities were in trouble, there were serious concerns about the credit rating of similar securities and the proper valuation of the credit risk. Almost a year later, the bank nearly failed, to be later rescued by financial assistance from the Federal Reserve. This news created fear of further mortgage-backed securities defaults and tightened many market lenders' willingness to lend. The contagious effect of the deterioration in the US housing market was spread over other markets as well and contributed to mild recessions in many economies after the third quarter of 2008, when Lehman Brothers - a large US investment bank defaulted and when American International Group (AIG) - the largest US insurance company - was rescued at the last moment. This triggered a systemic risk crisis with serious liquidity problems throughout the global financial system. In August 2007, BNP Paribas stopped valuing three of its funds and suspended all withdrawals due to significant liquidity deterioration. These moves by the French bank triggered a sharp rise in the cost of credit, which pushed many institutions to close the "valves" of lending in the global financial market.

The roots of the current crisis, however, can be traced back to previous growth periods, when financial institutions expanded their risk exposure and took highly leveraged balance sheet positions. During the 1990s, in an attempt to face the US stock market decline and to boost the economy by increasing the supply of credit, the Federal Reserve cut interest rates, encouraging the process of borrowing money. This triggered a hike in the market for hedge funds and other exotic and complex securities and thus caused very low risk spreads in the financial market, significantly under-pricing credit risk. ${ }^{52}$ Concurrently, with a steady growth in output and

${ }^{52}$ In appendix 4-A we provide a detailed discussion on the role of credit protection and securitized transactions in the crisis. 
with inflation at low levels, mortgages became very cheap and appealing. ${ }^{53}$ The immediate result was an increase in house prices, which led to an expansion of borrowing to households who could not previously afford mortgage credit. ${ }^{54}$ In the following years, the rapid increase in real estate prices was inevitable (Laeven \& Valencia, 2008). In 2006, the Federal Reserve decided to increase interest rates in an attempt to fight inflation, which was rising above target levels. Many borrowers, especially those with adjustable rate mortgages, were unable to maintain their interest and amortization payments due to the higher interest rates. At the same time, house prices started to decline and houses could only be resold at a loss. In 2007, the first defaults occurred and foreclosures started rising.

Under the pressure of these events, large write-downs caused a huge increase in the perceived counterparty risk and the demand for liquidity exploded, making the latter even more expensive. The widening of corporate bond spreads, the depression of most liquid government securities and the collapse of credit lines for hedge funds accompanied a rapid increase of liquid asset prices. As a result banks started to tighten their credit standards, while at the same time equity prices began to fall rapidly and the circulation of finance and working capital was severely distorted (IMF, 2009b). The drop in equity prices and house prices led to a significant loss of household wealth. It was clear than the crisis was transmitting from the financial sector towards other sectors of the economy.

\subsubsection{Government responses}

The developing crisis necessitated immediate action from governments and direct interventions. The aims of policy makers were to sustain market liquidity, capitalization and solvency (IMF, 2009d) using specific measures of guarantees

\footnotetext{
53 In addition, the US government subsidised real estate financing, deducting interest payments from the taxable household income.

${ }^{54}$ Real estate borrowers were attracted to adjustable rate, no documentation and / or piggy-packed mortgages.
} 
schemes, buy-outs and liquidity enhancement programs. The Federal Reserve, for example, in order to lower systemic risk, decided to decrease its federal funds rates and the discount rates so as to provide liquidity to the financial market. Other central banks also followed the path of reducing rates, while at the same time engaging in open market operations, by purchasing long-term government securities (Laeven \& Valencia, 2008).

These policies however did not prove entirely effective. Even though central banks played their role as chief financial intermediaries, significantly expanding their balance sheet exposure, it seemed as if monetary policy could not provide the proper answer. At the same time the fiscal condition of various countries deteriorated, because of the increased public spending that was driven towards these actions, with serious negative effects on public debt, especially for countries that faced fiscal difficulties. ${ }^{55}$ After the collapse of Lehman Brothers, some major financial institutions received public support, such as capital injections and guarantees. In many cases, however, these policy responses were not proved effective and were complemented by other measures.

\subsection{Lessons from previous crisis episodes}

There is a growing literature focusing on the different policy measures that were implemented in different periods of banking crises. Reinhart and Rogoff (2008) draw data from eighteen bank-centred financial crises from the post war period and use it as a benchmark for the U.S. subprime crisis. They categorize five different groups of crises, the "Big Five," and compare the current crunch with previous episodes. They conclude that unregulated financial entities play a much more significant role in the financial system and identify some qualitative and quantitative parallels with previous crises. These constitute the decline in productivity growth and house

\footnotetext{
55 Additionally, due to the weakened fiscal positions, many countries faced increased government bond yields that constituted a further negative effect on fiscal sustainability.
} 
prices and the large volume of cash flows that were channelled into the subprime mortgage market.

Honohan and Klingebiel (2003) examine the impact of crisis management measures on fiscal costs. They analyze 40 crises around the world and do not find any evidence that the measures reduce fiscal costs. They do find that "blanket deposit guarantees, open-ended liquidity support, repeated (and thus initially inadequate or partial) recapitalizations, debtor bailouts and regulatory forbearance add significantly and sizably to costs" (Honohan and Klingebiel, 2003, page 2). They conclude that countries that avoid these policies can significantly reduce the cost of future crises and propose either a strict approach to face banking crises, or an accommodating approach where the authorities have the ability to control risk taking.

An IMF working paper (Laeven and Valencia, 2008) describes a new dataset with policy responses from various countries during the period 1970-2007, including all "systemically important banking crises" (Laeven \& Valencia, 2008, page 5). According to their definition, "in a systemic banking crisis, a country's corporate and financial sectors experience a large number of defaults and financial institutions and corporations face great difficulties repaying contracts on time" (Laeven and Valencia, 2008, page 7). They group the remedy measures into two pools: immediate policy responses and main policy approaches in the resolution phase. The first group consists of: a) suspension of convertibility of deposits, which prevents bank depositors from seeking repayment from banks, b) regulatory capital forbearance, which allows banks to avoid the cost of regulatory compliance $^{56}$, c) emergency liquidity support to banks, or d) a government guarantee of depositors. The second group of measures includes a) conditional government-subsidized, but decentralized, workouts of distressed loans, b) debt forgiveness, c) the establishment of a government-owned asset management company to buy and resolve distressed loans; (d)

\footnotetext{
${ }^{56}$ This can be achieved, for example, by allowing banks to overstate their equity capital in order to avoid the costs of contractions in loan supply.
} 
government-assisted sales of financial institutions to new owners, typically foreign and (e) government-assisted recapitalization of financial institutions through injection of funds. They emphasize that regulatory forbearance (that allows the gradual transition to stricter prudential requirements), tools to provide liquidity and recapitalization measures are three of the most common features of the global crisis management. However, since these measures cannot resolve all systemic problems, a bank-restructuring plan seems to be a necessity. In conclusion, a successful plan tends to be selective in its financial assistance to banks, while the adverse impact on the balance of the real economy has to be constrained. Table 4.1 summarizes the different policy measures as presented by Laeven and Valencia (2008).

Table 4.1: Crisis policies of 42 banking crises episodes, 1970-2007

\begin{tabular}{|c|c|}
\hline Policy measure & Characteristics / Details \\
\hline Deposit freeze & Duration and coverage of deposit freeze \\
\hline Bank holiday & Duration of bank holiday \\
\hline Blanket guarantee & $\begin{array}{l}\text { Duration of guarantee, previous explicit deposit } \\
\text { insurance arrangement }\end{array}$ \\
\hline $\begin{array}{l}\text { Liquidity support / } \\
\text { emergency lending }\end{array}$ & $\begin{array}{c}\text { Collateral, interest at market rates, lowering of } \\
\text { reserve requirements }\end{array}$ \\
\hline Forbearance & $\begin{array}{c}\text { Banks not intervened despite being technically } \\
\text { insolvent, prudential regulations suspended or not } \\
\text { fully applied }\end{array}$ \\
\hline $\begin{array}{l}\text { Large-scale government } \\
\text { intervention }\end{array}$ & Bank / financial institutions closures \\
\hline Nationalizations & - \\
\hline Mergers & Private capital by bank shareholders \\
\hline Sales to foreigners & - \\
\hline Bank restructuring agency & - \\
\hline $\begin{array}{c}\text { Asset management } \\
\text { company }\end{array}$ & - \\
\hline Recapitalization of banks & $\begin{array}{l}\text { Recapitalization level, recapitalization cost to } \\
\text { government, recovery of recapitalization expense, } \\
\text { recovery proceeds }\end{array}$ \\
\hline Deposit insurance & Coverage limit, losses on depositors \\
\hline
\end{tabular}




\subsection{Interventions in the current crisis}

On March 2009, during the meeting of the G20 ministers and central bank governors, the policymakers evaluated the national responses to the banking crises. The basic aim was twofold: to restore creditor confidence and financial stability. This would be implemented via an international strategy with five elements: international cooperation for restructuring and recapitalization policies, an international framework for valuing and disposing of toxic assets, quick actions for inspecting financial institutions (in terms of liquidity and solvency), institutional frameworks for public holdings of banks (to ensure that recapitalized banks operate suitably) and an effective communication strategy. The G20 members emphasized lessons from previous crises. More specifically they referred to possible underestimation of the impact of previous crises and to the need for system-wide and comprehensive measures. They categorized the policy actions into two phases: a) containment and b) restructuring and resolution. Table 4.2 below summarizes all sub-measures that are implemented under each phase. Their evaluation of the remedies indicated that, even though "the efforts to contain creditor flight were largely successful" (IMF 2009d, page 13), the impact on the financial positions of banks was limited. At the same time, the solutions have not prevented the growing lack of confidence in the banking system. Final recommendations included the need for reinforcement of stabilization policies, direct actions for bank restructuring and the development of a comprehensive management strategy.

Given the above, all countries share three basic priorities to repair the financial sector: a) ensuring that financial institutions have access to liquidity, b) identifying and dealing with distressed assets, and c) recapitalizing weak but viable institutions and resolving failed institutions (IMF, 2009a). 
Table 4.2: Overview of policy measures, G20, Spain and Netherlands

\begin{tabular}{|c|c|c|c|c|c|c|c|c|c|c|c|}
\hline \multirow[b]{3}{*}{ Country } & \multicolumn{5}{|c|}{ Containment } & \multicolumn{6}{|c|}{ Resolution } \\
\hline & \multicolumn{2}{|c|}{ Deposit Insurance } & \multicolumn{2}{|c|}{ Debt Guarantees } & \multirow{2}{*}{$\begin{array}{c}\text { Liquidity } \\
\text { New } \\
\text { Measures } \\
\text { Introduced }\end{array}$} & \multicolumn{3}{|c|}{ Recapitalization } & \multicolumn{3}{|c|}{ Asset Management } \\
\hline & $\begin{array}{l}\text { No } \\
\text { Change }\end{array}$ & $\begin{array}{c}\text { Establish } \\
\text { Increase } \\
\text { or } \\
\text { Expand }\end{array}$ & $\begin{array}{l}\text { Wholesale } \\
\text { borrowing }\end{array}$ & $\begin{array}{c}\text { Amount } \\
\text { Committed } \\
\text { (bn of } \\
\text { US\$) }\end{array}$ & & $\begin{array}{c}\text { Capital } \\
\text { Plans } \\
\text { Established }\end{array}$ & $\begin{array}{l}\text { Capital } \\
\text { Committed } \\
\text { (bn of } \\
\text { US\$) }\end{array}$ & $\begin{array}{c}\text { Capital } \\
\text { Injected } \\
\text { (bn of } \\
\text { US\$) }\end{array}$ & $\begin{array}{l}\text { Asset } \\
\text { Purchase } \\
\text { Plans }\end{array}$ & $\begin{array}{l}\text { Amount } \\
\text { Committed } \\
\text { (bn of } \\
\text { US\$) }\end{array}$ & $\begin{array}{c}\text { Loan } \\
\text { Guarantees }\end{array}$ \\
\hline Argentina & $\sqrt{ }$ & & & & & & & & & & \\
\hline Australia & & $\sqrt{ }$ & $\sqrt{ }$ & unclear & $\sqrt{ }$ & & & & $\sqrt{ }$ & 5,2 & \\
\hline Brazil & $\sqrt{ }$ & & & & $\sqrt{ }$ & & & & $\sqrt{ }$ & 3,8 & \\
\hline Canada & $\sqrt{ }$ & & $\sqrt{ }$ & unclear & $\sqrt{ }$ & & & & $\sqrt{ }$ & 59,6 & \\
\hline China & $\sqrt{ }$ & & & & $\sqrt{ }$ & $\sqrt{ }$ & & 19,2 & & & \\
\hline France & $\sqrt{ }$ & & $\sqrt{ }$ & 402 & & $\sqrt{ }$ & 50,3 & 17 & & & $\sqrt{ }$ \\
\hline Germany & & $\sqrt{ }$ & $\sqrt{ }$ & 503 & & $\sqrt{ }$ & 100,5 & 26,6 & $\sqrt{ }$ & 6,3 & $\sqrt{ }$ \\
\hline India & $\sqrt{ }$ & & & & $\sqrt{ }$ & & & & & & \\
\hline Indonesia & & $\sqrt{ }$ & & & $\sqrt{ }$ & & & & & & \\
\hline Italy & $\sqrt{ }$ & & $\sqrt{ }$ & unclear & $\sqrt{ }$ & $\sqrt{ }$ & 25,1 & & & & $\sqrt{ }$ \\
\hline Japan & $\sqrt{ }$ & & & & $\sqrt{ }$ & $\sqrt{ }$ & 120 & & $\sqrt{ }$ & 27,6 & \\
\hline Mexico & $\sqrt{ }$ & & $\sqrt{ }$ & 3 & $\sqrt{ }$ & & & & & & \\
\hline Netherlands & & $\sqrt{ }$ & $\sqrt{ }$ & 251 & $\sqrt{ }$ & $\sqrt{ }$ & 25,1 & 22,3 & & & \\
\hline Russia & & $\sqrt{ }$ & $\sqrt{ }$ & unclear & $\sqrt{ }$ & $\sqrt{ }$ & 26,6 & 20,3 & $\sqrt{ }$ & 6 & \\
\hline $\begin{array}{c}\text { Saudi } \\
\text { Arabia }\end{array}$ & & $\sqrt{ }$ & $\sqrt{ }$ & unclear & $\sqrt{ }$ & $\sqrt{ }$ & & 2,7 & & & \\
\hline $\begin{array}{l}\text { South } \\
\text { Africa }\end{array}$ & $\sqrt{ }$ & & & & & & & & & & \\
\hline Spain & & $\sqrt{ }$ & $\sqrt{ }$ & 126 & & $\checkmark$ & unclear & & $\sqrt{ }$ & 62,8 & $\sqrt{ }$ \\
\hline $\begin{array}{l}\text { South } \\
\text { Korea }\end{array}$ & $\checkmark$ & & $\sqrt{ }$ & unclear & $\sqrt{ }$ & $\sqrt{ }$ & 15,5 & 2,3 & $\sqrt{ }$ & 3,8 & \\
\hline Turkey & $\sqrt{ }$ & & & & & & & & & & \\
\hline $\begin{array}{c}\text { United } \\
\text { Kingdom }\end{array}$ & & $\sqrt{ }$ & $\sqrt{ }$ & 355 & $\sqrt{ }$ & $\sqrt{ }$ & 71 & 52,6 & $\sqrt{ }$ & 71 & $\sqrt{ }$ \\
\hline $\begin{array}{l}\text { United } \\
\text { States }\end{array}$ & & $\sqrt{ }$ & $\sqrt{ }$ & unclear & $\sqrt{ }$ & $\sqrt{ }$ & 700 & 236 & $\sqrt{ }$ & 1.100 & $\sqrt{ }$ \\
\hline Total & & & & & & & 1.134 & 399 & & 1.346 & \\
\hline
\end{tabular}

\subsection{Categorizing the interventions}

For the purpose of our analysis, we identify three different types of interventions. First, asset management relates to purchases of bank assets and any guarantees for future asset losses. Second, liabilities management contains guarantees in the form of deposit insurance and debt guarantees. Third, equity management refers to direct equity injections, such as stock acquisition or (partial) nationalization.

\subsubsection{Asset management}

Several countries set up asset management companies to manage asset-side policies. The usual practice is that the government buys toxic securities, taking them out of the bank's balance sheet with a price discount, so that its value will be much lower than the nominal value. Another similar intervention is to remove bad assets from banks' balance 
sheets, transferring them to publicly-owned financial management companies, with possible repurchase arrangements. Moreover, asset management includes actions for the minimization of further losses from these assets as well. Guarantees for potential asset losses are typically realized by securing these assets via ring fencing. The aims of the above asset-side measures are twofold: a) to decrease a bank's leverage and b) to liquidate the bank's debt position via removing bad assets from its balance sheet. ${ }^{57}$

Loan loss provisioning is another subcategory of asset management. The government can cover some loan losses from subprime mortgages by setting aside an expense as an allowance for bad loans. The measure is most effective for relatively small financial institutions with relevantly low exposure on the systemic risk that resulted from the credit crisis. $^{58}$

Similar accommodating policies can be also implemented on the other part of the income statement. It is very common that governments decide to empower the capital base of banks through increased profits. This includes waivers of capital requirement through either explicit or implicit forbearance. The restoration of bank profitability can be also achieved through debt relief programs for lenders to facilitate repayment of their bank loans.

In Figure 4.1 we portray the main features of balance sheet asset management interventions.

\footnotetext{
${ }^{57}$ The price of these assets is given by their book value in the pre-crisis period minus a discount that corresponds to the losses that resulted from these core assets or from financial instruments that were backed up by these assets. The price of a random asset $\mathrm{j}$ at time $\mathrm{t}\left(\mathrm{A}_{\mathrm{j}, \mathrm{t}}\right)$ is given by its book value at the pre-crisis period $\left(\mathrm{V}_{\mathrm{j}, \mathrm{t}}\right)$ minus this pre-crisis value times the discount percentage at time $\mathrm{t}\left(\mathrm{d}_{\mathrm{j}, \mathrm{t}}\right)$ :

$\mathrm{A}_{\mathrm{j}, \mathrm{t}}=\mathrm{V}_{\mathrm{j}, \mathrm{t}} *\left(1-\mathrm{d}_{\mathrm{j}, \mathrm{t}}\right)$.

${ }^{58}$ However, in some countries (for example, United States and Japan) the government did not allow this arrangement.
} 


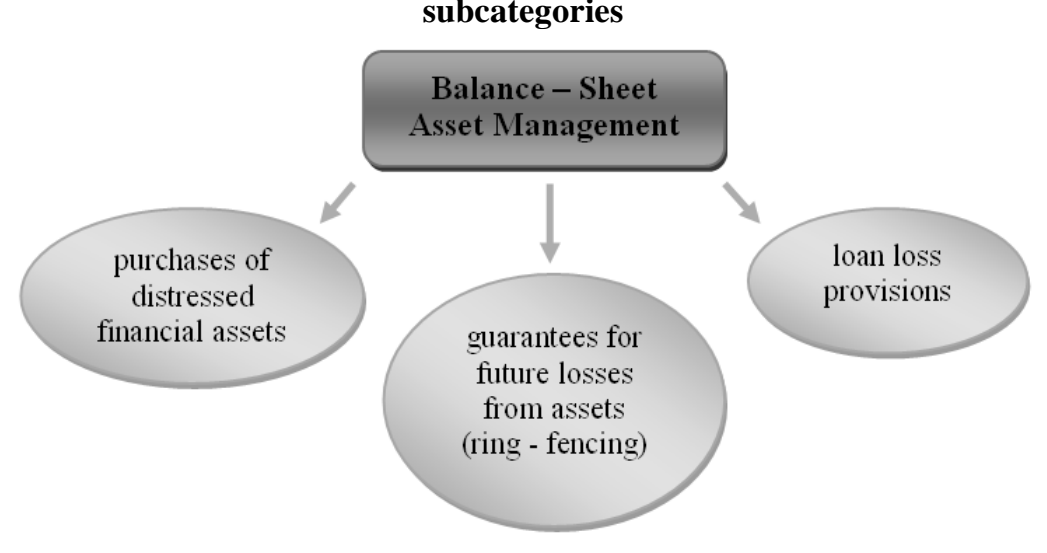

Source: Author's contribution.

\subsubsection{Liabilities management}

Balance sheet restructuring also concerns liabilities management, which aims to deleverage banks. The government alleviates a bank's debt position via freeing some of its cash flows, so that it can service amortization and / or interest payments. Guarantee schemes in the form of deposit insurance or other warranties on interest payments, principal payments and interbank liabilities was a very common remedy measure, which was applied in most of the countries that were affected by the credit crisis. Another famous remedy that was globally implemented was the increase of deposit guarantees (usually referred to as blanket guarantees), which signify government protection of deposits.

The magnitude and extent of the financial systemic crises dictated extra liability-side measures. More specifically, many countries implemented the provision of guarantees, not only for deposits, but also for debt issuance programs for bank borrowing, aimed at banks that are in immediate need for external financing. The main advantage of such a program for banks is that they can borrow at a risk free interest rate plus a relative fee towards the government. This somehow eases the interbank lending, since the scheme is favorable to two types of banks: on the one side, solvent banks can lend funds with public protection, while "bad" banks can borrow cheaply. 
A final aspect of balance sheet liabilities management concerns the prudential regulation of banks. Forbearance refers to the situation where banks are permitted to operate in spite of the fact that they are technically insolvent. This was indirectly implemented in some countries as an accommodating measure against systemic failure. It foresees the suspensions of prudential regulations such as loan classifications and loan loss provisioning (IMF, 2009c). Presumably, the strict prudential regulations that implement restraining actions for an illiquid bank that enters into prolonged and severe trouble are altered. This is done in order to incorporate an accommodating approach that includes extensive liquidity loans, even to significantly insolvent banks. This allows banks to meet their short-term loan obligations. Eventually, in many liability-side government support schemes, blanket guarantees that were granted to depositors in order to restore their confidence in the banking system, were combined with bank debt protection programmes that would assist troubled and illiquid banks. Figure 4.2 below shows the subcategories of balance sheet liability management.

\section{Figure 4.2: Groups of Interventions, Liabilities Management and} subcategories

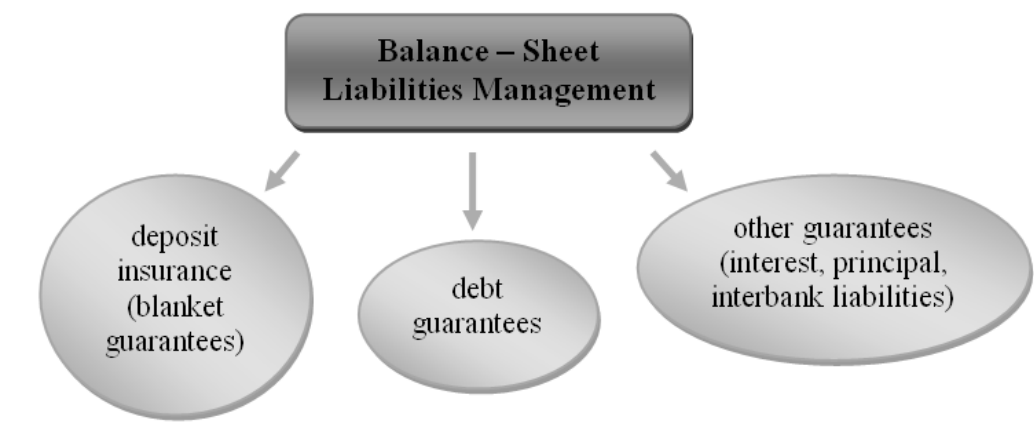

Source: Author's contribution.

\subsubsection{Equity management}

As part of the crisis resolution, governments commonly recapitalize systemically important banks. In doing so, they address illiquidity as a negative effect of the crisis. 
This measure also reveals the role of the central bank as lender of last resort, when it tries to maintain liquidity for solvent banks. The public capital adds to or replaces a bank's third party or equity financing. Under this provision, there usually exist repurchase agreements, where a bank can bail out, getting back the shares that were acquired by the government and providing the latter with an additional premium for entering into this process.

More specifically, this group of measures incorporates the following: a) direct equity injections in share capital by purchases of either preferred or common stocks, b) pure nationalizations, c) partial nationalizations, d) mergers with public or quasi-public financial institutions, e) recapitalizations and f) bank closures. ${ }^{59}$ Generic recapitalization of banks may include specific actions of equity enhancement. The basic formats are: direct cash inflows, government bonds, subordinated debt, purchases of bad loans, credit lines, assumption of bank liabilities, ordinary and preferred shares, or other means (IMF, 2009c).

Current policy measures are designed to resolve issues of bank insolvency and illiquidity. The choice of either an accommodating policy of forbearance and guarantees, or a hardcore policy ${ }^{60}$ with capital injections, (partial) nationalizations and purchases of distressed assets is a basic dilemma for policymakers. Figure 4.3 below consolidates the four main measures of remedies via capital injections and / or recapitalization.

\footnotetext{
59 Bank and other financial institution closures entail a significant government intervention for the banking system, even if they do not constitute a nationalization or capital injections measure. These closures often incorporate shareholder protection schemes and are usually measures of last resort since attempts for mergers, acquisitions and mere or partial nationalization were initially realized. They occurred in most cases for minor investment banks and not for systemically important financial institutions.

${ }^{60}$ Policies that come along with significant bank managerial decisions such as restraining management, personnel changes, mergers or acquisition measures and liquidations.
} 


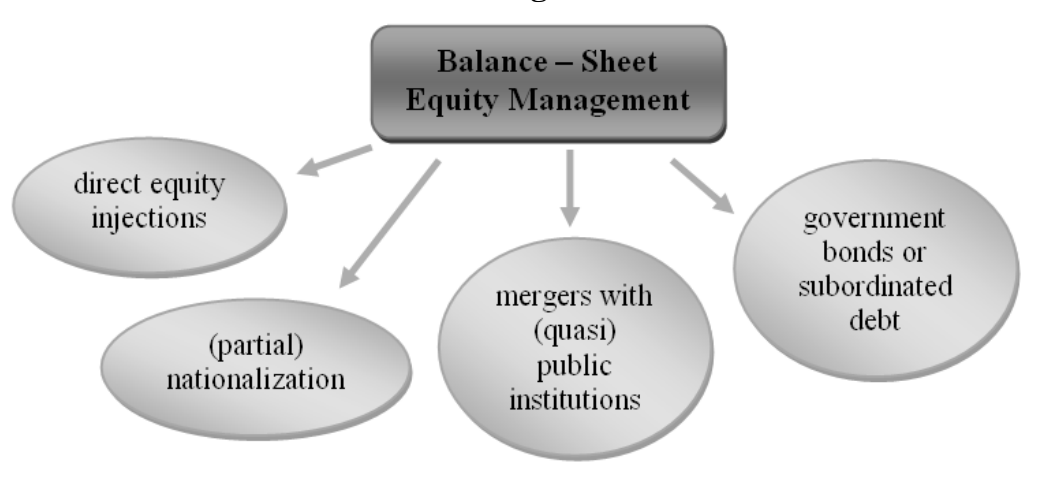

Source: Author's contribution.

\subsection{Conclusion}

Buyouts of distorted assets can enhance liquidity for troubled banks, which have a serious incentive to sell their undervalued assets, while the public side can potentially profit from these assets, since they purchase them at a discount. However, the government can be trapped into the irreversible underdog position of obtaining huge quantities of toxic waste. ${ }^{61}$ It is a fact that many market actors did not adequately value the off-balance sheet risk of these securities, which created information asymmetries about the magnitude and consequences of the relevant exposures. The real challenge for policymakers, when attempting to remove bad assets from the bank balance sheet through the rescue programs, will be to set a correct price for these assets. To this effect, governments must establish a common methodology for the proper valuation of transparent credit instruments, while the volatility of such exposures must be reduced. Even if the valuation of complex troubled financial assets is very difficult, it can be achieved by realistically and conservatively assessing future income streams from these assets.

\footnotetext{
${ }^{61}$ The IMF suggests a more precise valuation of asset-backed securities by the creation of valuation reserves, if "market prices deviate rapidly from trend (or possibly an estimate of underlying value), building up a buffer during upswings to be drawn down in downturns" (IMF, 2009c, page 13).
} 
Recapitalization, in the form of government bonds, provides support for a bank with severe liquidity problems. However, it can have negative effects in terms of solvency. For example, subordinated debt could raise a bank's liabilities, which creates serious solvency considerations, especially for banks with sizeable exposures. Additionally, as was the case with distressed assets, there is a need for a realistic valuation of all expected losses from problematic securities. Thus, the measure has a managerial and a business strategy aspect. The (partial) nationalization of viable institutions can be successfully implemented via establishing thresholds of regulatory capital. In any case, ownership must be returned to the private actors in a sensible period of time. On the other hand, nonviable institutions should be faced in different ways, considering options such as closures or mergers. Consequently, an issue that emerges, concerns the characterization of solvent (or insolvent) banks. A legal framework is imperative to this effect. By benchmarking credit events that trigger defaults, governments can define insolvency and design the appropriate intervention. Ultimately, the government should only deal with financial institutions can maintain solvent capital requirements and spill the positive externalities of the rescue over the financial market. In any other case, the opportunity cost of the rescue will exceed the future benefits of restoring the banking sector.

There are specific drawbacks that relate to the implementation of guarantee programs as well. Moral hazard for banks and depositors is the main consideration. In essence, a government guarantee is equivalent to a put option on bank assets. Thus, banks (and depositors) will be tempted to "care less" about defaults and fund lodging, especially if monitoring mechanisms are lenient, deficient and inadequate. Furthermore, there is the risk of increasing (contingent) potential fiscal costs from guarantees. If a large volume of guarantees is granted to potential recipient institutions and if these guarantees are not aptly valued, then the fiscal costs of forthcoming periods may be substantial. This is because impending bailouts and default recoveries that could result 
from guarantees in the future, may generate the need for further use of public funds with negative macroeconomic effects in government balances and public debt.

The advantages of liability side policies though can overcome the above downsides. The most concrete argument is that guarantees are the best way to restore trust of depositors and investors in the financial system. Since depositors are risk averse, they will suffer direct and extensive losses, if they are not covered by a deposit protection scheme. If they do suffer losses, they will decrease their consumption, not being able to easily liquidate other assets. Furthermore, deposit insurance schemes are beneficial for enhancing financial intermediation, since depositors will not be forced to withdraw their deposits to other viable and solvent institutions. ${ }^{62}$

Finally, we argue that with guarantees, the maximum exposure for the government is well known. This is the exact amount that is committed, either for deposit insurance, or for guarantees covering potential future asset losses (ring-fencing) or for other debt guarantees on principal and interest. All the above contingent obligations can be adequately evaluated as well, using specific option valuation techniques.

We expand more on the above issues in the coming chapter, where we further analyze accounting and valuation principles. More specifically, we extend the balance sheet approach to assess effects of specific groups of interventions. Using two sectoral balance sheets, one that represents the public sector and the other one depicting the banking sector, we indicate the neutrality of each intervention, the effect on the capital requirement and the importance of the macroeconomic shocks for asset valuation. Table 4.3 summarizes all basic goals and concerns of government responses to the financial crisis, according to each intervention group.

${ }^{62}$ For a more detailed discussion on the positive effects of deposit protection, see Haldane et al. (2004). 
Table 4.3: Aims and risks of remedies for the government

\begin{tabular}{|c|c|c|c|}
\hline Intervention Group & Aims & \multicolumn{2}{|c|}{ Risks } \\
\hline Asset Management & $\begin{array}{c}\text { deleverage } \\
\text { and } \\
\text { liquidate }\end{array}$ & $\begin{array}{c}\text { public side can be } \\
\text { brought in } \\
\text { underdog position }\end{array}$ & $\begin{array}{c}\text { increased } \\
\text { risk profile }\end{array}$ \\
\hline Liabilities & deleverage & $\begin{array}{c}\text { guarantees create } \\
\text { government } \\
\text { explicit contingent } \\
\text { liabilities }\end{array}$ & $\begin{array}{c}\text { moral hazard } \\
\text { in terms of } \\
\text { risk } \\
\text { management }\end{array}$ \\
\hline Equity Management & liquidate & $\begin{array}{c}\text { insolvency by } \\
\text { increased } \\
\text { liabilities }\end{array}$ & $\begin{array}{c}\text { high volume } \\
\text { of risky } \\
\text { assets }\end{array}$ \\
\hline Sources: $\quad 1 . I M F, 2009 \mathrm{C}$ & & & \\
\hline
\end{tabular}

2. Author's contribution. 


\section{Crisis balance sheet analysis and fiscal commitments}

\subsection{Introducing the balance sheet approach}

This chapter extends the previous analysis with the categorization and initial policy implications of intervention groups, applying a balance sheet approach. The prime research question of the chapter is to investigate how an intervention is traced within the balance sheet of two particular sectors: the public and the banking sector (see Rosenberg et. al, 2005). In section 5.2, we analyze the changes in the two balance sheets, for each different type of public interventions: an asset purchase (asset management), a guarantee commitment (liabilities management) and a direct capital injection (equity management). To make the analysis more realistic, we use G20 averages of the actual fiscal costs of the above three measures. Further on, we address how each intervention influences the capital adequacy requirement (as measured by Tier I ratio) of the banking system as a whole. Thus, we have a holistic image of the magnitude and the neutrality of each measure. Extending this analysis for a single intervention, we also show the balance sheet and capital adequacy alterations when there are combinations of two or three interventions. ${ }^{63}$

The second contribution of this chapter consists in explaining certain valuation aspects of asset and liabilities side management. This allows us to draw arguments on which intervention is the most difficult to evaluate appropriately and accurately. In section 5.3, we discuss valuation principles of off-balance sheet exposures (with a clear focus on guarantees)

\footnotetext{
63 Previous literature (Laeven and Valencia, 2008, IMF, 2009b, IMF, 2009d, IMF, 2009e) mainly focused on the categorization and the fiscal costs of crisis remedies. Rosenberg et al. (2005) develop a conceptual framework on the balance sheet approach. They evaluate the shocks on assets and liabilities that may trigger large adjustments in capital flows. Following their work, we extend the balance sheet approach by using actual values to observe the modifications on the balance sheets and the capital requirement of the banking system.
} 
and review the relevant literature. ${ }^{64} \mathrm{~A}$ common finding is that there are concrete and transparent (finance) methods to calculate contingencies from the public sector such as government guarantees. In any case, as we later argue, these maximum exposures are well known. We also compare this analysis with asset portfolio risk and asset valuation. The main target is to address the effect of the macroeconomic shock, which is revealed through market approach accounting. ${ }^{65}$ This shock affects the estimation of a proper value for a bank asset and respectively the value of a bank as a firm. As such, it is difficult for the government to set a proper price when purchasing a distressed asset (asset management). It is also complicated to approximate the value of the bank as a firm when acquiring shares (equity management), since this is highly depended upon the pricing of its financial assets.

Finally, section 5.4 concludes. It links this chapter with chapter six by describing the crisis responses of the G20 countries and the consequences that the interventions have on fiscal balances and public debt.

\subsection{The balance sheet effect}

\subsubsection{The balance sheet and the bank's performance}

A typical bank's balance sheet has the generic format of figure 5.1. Dewatripont and Tirole (1993) distinguish a bank's performance in two measures: the verifiable performance that includes a) the value of the loans maturing in period 1 plus net capital gains on assets and b) the assets whose value is not realized yet. The final profit realized in period 2, depends on the managerial choice at the end of period. The authors initially simplify their analysis focusing on two managerial actions: a) stopping vs intervening and b)

\footnotetext{
${ }^{64}$ This review includes the most significant representatives of the sizeable literature on the valuation of guarantees and similar contingent obligations, such as Merton, 1977 and 1990, Avery and Berger, 1991, Boot and Thakor, 1991, Merton and Bodie, 1992. In appendix 5-A, we shortly refer to literature on the management of government guarantees.

65 Refer to Dewatripont and Tirole's (1993) work on off-balance sheet operations and asset valuation.
} 
continuing vs being passive. For our analysis we focus on the government's choice to intervene in order to restore solvency and liquidity of banks that is realized through the different measures, namely asset purchases, equity injections or guarantees. $^{66}$

Figure 5.1: A simplified bank balance sheet

\begin{tabular}{l|l}
\multicolumn{1}{c|}{ Assets } & \multicolumn{1}{c}{ Liabilities and Equity } \\
\hline Cash & Interbank deposits \\
Credit to third parties & Retail and wholesale deposits \\
Interbank loans & Subordinated debt \\
Equity holdings & Equity (stocks and retained earnings) \\
Equipment and buildings &
\end{tabular}

Source: Dewatripont and Tirole, 1993.

The optimal incentive scheme (Dewatripont and Tirole, 1993) dictates that in the case of poor bank performance, there is a threat of frequent external interference, while with good performance a passive attitude may be guaranteed. Assuming that the intervention action is riskier than the "doing nothing" action, shareholders have a "risk loving" tendency, while depositors seem to be more conservative. ${ }^{67}$ The result is that these two biases can bring upon negative externalities on a bank's solvency. On the one hand, the shareholders' tendency towards more risk can decrease solvency, while on the other hand, the risk aversion of depositors can also lower solvency. This theoretical approach has a serious implication in the current crisis. We can initially surmise that, since the government cannot restore the shareholders' trust by equity injections or asset purchases, the real target should consist in reinstating the faith of depositors. The government, by insuring deposits of risk averse depositors, can limit the negative effects on solvency on the liability-side of the balance sheet.

\footnotetext{
${ }^{66}$ Dewatripont and Tirole (1993) also focus on external interference as a managerial discipline device.

${ }^{67}$ As noted by the authors, claimholders with convex return streams are riskier than claimholders with concave return streams.
} 


\subsubsection{Balance sheet risk and adjustments}

An occasional paper by the IMF (Rosenberg et al., 2005) describes the conceptual framework of the balance sheet approach in order to assess debt vulnerability. The approach is based on measuring the linkages between assets and liabilities that may trigger large adjustments in capital flows. If enough data are available, it can also incorporate off-balance sheet items such as contingencies, guarantees and derivatives. We follow this analysis to differentiate between the historical and the market value of a bank asset. The deviation of this value, using either the balance sheet approach or the market value approach, constitutes the main source of uncertainty, when setting an appropriate price for an asset. On the side of public finances, the balance sheet approach looks at foreign reserves, loans outstanding, inventory and public debt at a specific point in time. It also distinguishes three sectoral balance sheets, the government balance sheet, the private financial sector balance sheet and the non-financial sector balance sheet. We observed the basic balance sheet adjustments for the government and the financial sector following a specific government intervention. In this way, as Rosenberg et al. (2005) emphasize, we are able to reveal the vulnerability of each sector due to a change in the asset and / or liabilities' stock. The authors also identify four different types of balance sheet risk that could potentially lead to specific patterns for capital account crises: maturity, currency, capital structure and solvency risk.

Maturity risk sources from maturity mismatches, which occur when long term illiquid assets mismatch with short term liabilities that could dangerously expose the country's position. This exposure is twofold, incorporating interest rate risk, if interest rates rapidly increase and rollover risk, when liquid assets cannot cover maturing debt. In this case, the government must seriously consider the large amounts of illiquid assets that they purchase from banks. The maturity exposure expands together with the increased volume in such assets. Currency risk is not directly affected by remedy interventions, since it refers to the mismatch of assets 
denominated in domestic currency and liabilities denominated in foreign currency. There can exist an indirect effect through domestic currency depreciation, in the case that the foreign currency liabilities stock is very high and, concurrently, a large volume of domestic currency financial assets are acquired, either in the form of bad loans or bank stocks. Capital structure risk aggregates, in essence, maturity and currency mismatches. It focuses though on a country's debt as measured by the debt to equity ratio (Pettis, 2001), capturing the risk exposure on the liabilities' side. This risk is attributed to the probability of assuming too much debt as this relates to the net worth. Apart from the above risks, we also mention generic market risks, which may include sharp decreases in asset prices (government bonds, equities, commodities, real estate), interest risk, credit risk, operational risk etc. All these risks together with currency and maturity mismatches might potentially lead to solvency risk, which may be later transformed into a crisis. In this situation, creditors and investors lose confidence in one or more balance sheet of the three main sectors of the economy.

\subsubsection{The effect of one intervention}

We consider, further on, Rosenberg et al.'s (2005) approach, as described above, to analyze two simplified balance sheets following a government intervention: the bank balance sheet ${ }^{68}$ and the government balance sheet. We observe the particular changes in the two balance sheets with respect to the intervention chosen by the government: a) asset management, b) liabilities management and c) equity management. We assess the balance sheet effects utilizing the following simplified model.

\footnotetext{
${ }^{68}$ This could depict the balance sheet changes of the banking system.
} 
Figure 5.2: Two sectoral balance sheets: the government and the bank

\begin{tabular}{|c|c|c|c|}
\hline \multicolumn{2}{|c|}{ The government } & \multicolumn{2}{|c|}{ The bank } \\
\hline Assets & Liabilities and Net Worth & Assets & Liabilities and Equity \\
\hline 15 Cash and deposits & Reserves & 30 Cash \& equity holdings & Deposits (interbank \& retail) 35 \\
\hline 20 Government secuities & Government securities (held by the public) 35 & 20 Interbank loans $(+)$ & Interbank loans (-) \\
\hline 30 Loans & External Debt & 40 Credit to third parties & Long - term debt \\
\hline 35 Fixed Assets & Net Worth & 10 Fired Assets & Equity \\
\hline 100 Total Assets & Total Liabilities \& Net Worth & 100 Total Assets & Total Liabilities \& Equity $\mathbf{1 0 0}$ \\
\hline
\end{tabular}

On the asset side of the government's balance sheet, the main components are the fixed assets, the public credit and the government owned securities, while the dominant liability concerns the public debt in the form of either external debt or government securities held by the public. In essence, the net worth of the government is the difference between its assets and its liabilities. The bank, in this simplified example, is in a balanced interbank lending position, since it is neither a net lender nor a net borrower. The rest of the assets are loans to third parties, securities and other equities and equipment and buildings. Liabilities, apart from interbank loans, consist of interbank and retail deposits, long term debt and owners equity. The ratio to measure the capital requirement relates equity and the bank's total risk adjusted assets. A straightforward manner to assess the capital adequacy of the bank is the Tier I ratio that captures the core capital, in the form of common stock and retained earnings, as a percentage of its risk weighted financial assets (excluding fixed assets). The formula is:

$\mathrm{r}_{\text {tierl }}=$ equity / (cash and equity holdings + interbank loans + credit) (5.1) Assuming $100 \%$ risk weight of all assets, then the Tier I solvency ratio of the banking sector in this case is: $5 /(30+20+40)=5,5 \%$.

Asset management, as aforementioned, mainly refers to purchases of distressed assets by the government and specific provisions for losses generated from these assets. These latter provisions mainly concern guarantees for future 
assets losses and are treated off-balance. ${ }^{69} \mathrm{We}$ can observe the liquidity effect following the previous simplified example and the respective changes on-balance, after a purchase of a "bad" loan of 4 units (figure 5.3). This is a realistic amount since an average of purchases of assets and lending by treasury for the G20 countries that implemented these measures is $3,64 \%$ of GDP. Under the assumption that the government, with this intervention, aims at enhancing the liquidity of the bank, it purchases the asset either by cash or by liquidating equity holdings.

Figure 5.3: Asset management balance sheet effect, purchase of distressed assets

\begin{tabular}{|c|c|c|c|}
\hline \multicolumn{2}{|c|}{ The goverminent } & \multicolumn{2}{|c|}{ The bank } \\
\hline Assets & Liabilities and Net Worth & Assets & Liabilities and Equity \\
\hline $11(-4)$ Cash and deposits & $\begin{array}{l}\text { Reserves } \\
\end{array}$ & $34(+4)$ Cash \& equity holdings & Deposits (interbank \& retail) 35 \\
\hline 20 Government sccuritics & Government sccuritics (hcld by the public) 3 & 20 Intcrbank loans $(+)$ & Interbank loans (-) \\
\hline $34(+4)$ Loans & External Debt & $36(-4)$ Credit to third parties & Long - term debt \\
\hline 35 Fixed Assets & Net Worth & 10 Fixed Assets & Equity \\
\hline $100 \quad$ Total Assets & Total Liabilities \& Net Worth & 100 Total Assets & Total Liabilities \& Equity $\mathbf{1 0 0}$ \\
\hline
\end{tabular}

The bank balance sheet effect as portrayed above concerns a rearrangement of the asset structure of the bank. The bank exchanges distressed and illiquid assets with "healthy" and liquid assets. Moreover, the capital requirement (Tier 1 ratio) remains unaffected, since there is only a trade-off between loans and cash, while other financial assets and equity do not change with the specific intervention.

Considering that, through guarantees for loan loss provisions, the bank can decrease its leverage and, through asset purchases, it can empower its liquidity position, the above analysis verifies our theoretical implication in previous chapter. Incorporating asset management interventions and

\footnotetext{
${ }^{69}$ We come back to the accounting of guarantees when we later discuss liabilities management with blanket and debt guarantees, since the approach is mutual in these cases.
} 
depending on the specific measure ${ }^{70}$ that is implemented, the government can either liquidate or deleverage target banks. ${ }^{71}$

Liabilities management refers, among others, to government guarantees. These guarantees can take the form of deposit insurance schemes (blanket guarantees), loan guarantees and other financial guarantees (such as guarantees for interest, principal and / or interbank liabilities). As with asset management guarantees, deposit protection aims at deleveraging the bank balance sheet position. Since guarantees are, by definition, off-balance sheet effects they are unobtrusive on-balance. Hence, they will not appear on the conventional balance sheet of either the government or the bank. To see how guarantees affect the bank's liquidity and / or solvency, we must consider an extended balance sheet that will capture the guarantee effect, considering it as an alternative bank asset and a potential (contingent) explicit liability for the government. ${ }^{72}$ Assuming, for example, a deposit insurance scheme with a nominal guarantee value of 13 units and with the bank's equity as collateral, the two extended balance sheets adjust as follows. ${ }^{73}$

Figure 5.4: Liabilities management balance sheet effect, guarantee provision (extended balance sheet)

\begin{tabular}{|c|c|c|c|c|}
\hline \multicolumn{3}{|c|}{ The goveminnent } & \multicolumn{2}{|c|}{ The bank } \\
\hline Assets & Liabilities and Net V & & Assets & Liabilities and Equity \\
\hline 15 Cash and deposits & Reserves & 10 & 30 Cash \& equity holdings & Deposits (interbank \& retail) \\
\hline 20 Government securities & Government securities (held by & public) 35 & 20 Interbank loans (+) & Interbank loans $(-)$ \\
\hline 30 Loans & External Debt & 40 & 40 Credit to third parties & Long - term debt \\
\hline 13 Bank Equaty & Explicit Guarantee & 13 & 13 Explicit Guarantee & $18\{+13$ \\
\hline 35 Fixed Assets & Net Worth & 15 & 10 Fixed Assets & \\
\hline $113(+13) \quad$ Total Assets & Total Liabilities \& Net Worth & $113(+13)$ & $113(+13) \quad$ Total Assets & Total Liabilities \& Equity 113 (+13) \\
\hline
\end{tabular}

\footnotetext{
${ }^{70}$ Either guarantees for loan loss provisions (ring - fencing) or distressed assets purchases.

${ }^{71}$ We discuss this mix of asset and liability side measures in a following section.

${ }^{72}$ For a further discussion on the use of extended balance sheets, see Merton and Bodie (1992).

${ }^{73}$ An average of G20 countries that committed guarantees is $13,5 \%$ of GDP.
} 
In the bank balance sheet we can see the guarantee as an asset, while in the government's balance sheet it appears as an explicit contingent liability. More specifically, in the asset side of the government there is an additional figure that depicts the bank's equity collateral to "insure" the guarantee, while on the liabilities side we show the guaranteed nominal amount. The bank's total assets increase by the amount of the guarantee, while its equity also increases, as a result of the collateralization. The extended balance sheet totals increase for both the government and the bank by the amount of the guarantee. Moreover, with increased financial assets and equity, there is a significant change in the Tier I capital ratio. ${ }^{74}$ Re-computing the latter and assuming $100 \%$ risk weight of all assets gives us: $18 /(30+20+40+13)=17,5 \%$.

Even though the guarantees do not officially appear in the conventional balance sheets, policy makers can assess their effect, managing extended balance sheet positions. The reason for this is twofold. Firstly, the latter approach can portray more accurately the overall risk exposure of both the government and the bank. This supports our first implications about the use of guarantees as the more efficient intervention, compared to asset management and direct capital injections. With guarantee schemes, the government can explicitly assess its maximum risk exposure by appropriately evaluating these guarantees. In any case this exposure is well known. On the other hand the valuation of distressed assets and the settlement of a "fair" price for these assets, are very difficult to manage. ${ }^{75}$

Secondly, the government can allocate equity capital more efficiently in terms of bank performance and prudential regulation. As we see from the balance sheet, the guarantee appears on the asset side and is counterbalanced by an increase in the bank's equity. This occurs by collateralizing

\footnotetext{
${ }^{74}$ The guarantee is considered a financial asset and therefore increases the denominator of the Tier I ratio.

${ }^{75}$ We expand more on in the next section, where we isolate the noise of macroeconomic effects on the bank balance sheet. This is the main element of the uncertainty of the value of a bank asset, which sources from the difference between its market and its accounting value.
} 
the equity (for example preferred stocks) in the framework of the guarantee scheme. The implication concerning the bank's performance is straightforward. Using the return on equity as a common measure of a bank's performance, the return on equity ratio will decrease, because of the increased equity in the extended balance sheet. Thus, the performance of the bank as measured with this ratio is significantly undervalued. In contrast, the implementation of guarantee schemes seem to overvalue the capital requirement adequacy of a bank, since the relative increase in equity is much greater than the relative increase in financial assets.

Capital injections and nationalization aim thoroughly at liquidating financial institutions. They incorporate mainly direct equity injections in the form of purchases of (either preferred or common) stocks, (pure or partial) nationalizations, mergers (and / or bank closures) and subordinated debt. We further analyze the accounting treatment of a direct cash inflow in one of the above formats. ${ }^{76}$ The average of direct capital injections that were realized for the G20 countries is $2,11 \%$ of GDP. Assuming a capital injection of 2 units, the relevant effect is shown in figure 5.5.

Figure 5.5: Equity management balance sheet effect, direct capital

\begin{tabular}{|c|c|c|c|c|}
\hline \multicolumn{2}{|c|}{ The government } & \multicolumn{3}{|c|}{ The bank } \\
\hline Assets & \multicolumn{2}{|c|}{ Liabilities and Net Worth } & Assets & Liabilities and Equity \\
\hline $13(-2)$ Cash and deposits & Reserves & 10 & \multirow{2}{*}{$\begin{array}{l}32(+2) \text { Cash \& equity } \\
\text { holdings }\end{array}$} & \multirow{2}{*}{ Deposits (interbank + retail) } \\
\hline 20 Govermment securities & Government securities (held by & & & \\
\hline 30 Loans & External Debt & 40 & 20 Interbank loans $(+)$ & Interbank loans (-) \\
\hline 2 Bank Equity & Net Worth & 15 & 40 Credit to third parties & Long - term debt \\
\hline 35 Fixed Assets & & & 10 Fixed Assets & Equity \\
\hline 100 Total Assets & Total Liabilities \& Net Worth & 100 & $102(+2) \quad$ Total Assets & Total Liabilities \& Equity $102(+2)$ \\
\hline
\end{tabular}

The government balance sheet changes asset structure. Since the aim is to liquidate the bank, the government exchanges cash with bank equity. On the bank side, we observe increased balance sheet totals. Liquid assets (cash) increase by the

\footnotetext{
${ }^{76}$ Excluding bank closures as measures of last resort since, even if they are considered significant government interventions, they do not constitute capital injections or recapitalization. In any case closures occurred during past crises only for minor investment banks.
} 
amount of the direct inflow, while the level of equity increases correspondingly.

As with liabilities measures, this intervention can undervalue the determinants of bank performance. ${ }^{77}$ If we evaluate this performance by the return on equity ratio, then the increased equity shows lower performance, ceteris paribus. The equity effect is also similar to the liabilities effect as far as capital requirements are concerned. The Tier I capital ratio (with $100 \%$ risk weight of all assets) is $7 /(32+20+40)=$ $7,6 \%$. Direct equity injections tend to overvalue the capital adequacy of financial institutions, because of the relatively higher increase in equity compared to financial assets.

Therefore, regulatory capital analyses must consider the fact that equity interventions significantly affect the capital requirement. Even if, in many cases, equity injections are implemented to fulfill regulatory capital requirements and thus restore solvency, policymakers should set different tiers for capital requirements incorporating as well the bank's leverage. In conclusion, when public capital adds up or replaces a bank's equity financing to enhance liquidity, the definition of bank solvency has to be transparent.

From the above analysis, we can address significant conclusions on the level of neutrality of each intervention group. Guarantees appear as the most neutral intervention on an accounting viewpoint, since they only impose off-balance effects. Nevertheless, these contingent commitments must be accurately disclosed and monitored. Asset purchases only rearrange the structure of both balance sheets. The bank substitutes liquid to distressed assets with the government. Respectively, there is no change in the balance sheet totals, the capital adequacy indicator and the return on equity ratio. However, this restructuring is very important in terms of the proper pricing of the asset that is being purchased. Finally, equity management seems to be the most influential and inclined intervention. It increases the bank's balance sheet totals and directly influences the Tier I capital requirement and

\footnotetext{
77 The mix of liabilities and recapitalization as crisis measures is further assessed in the next part.
} 
the return on equity ratio. Policymakers should be aware of these direct effects and the probable distortions and disparities that they may cause. Following the above, we further describe the results of intervention policy mixes, which are influenced by the neutrality of each intervention as discussed above.

\subsubsection{The effect of an intervention mix}

Figures 5.6 and 5.7 show the balance sheet modifications realizing, a) guarantees and asset purchases, and b) guarantees and direct equity injections respectively. We observe that the (extended) balance sheet totals increase for the government and the bank in both cases. Even if guarantees are the least influential intervention not affecting at all the conventional balance sheet, we observe that, in these two cases, they constitute the dominant intervention. More specifically, combining them with asset purchases, it is noticeable that, apart from the balance sheet restructuring between liquid and illiquid assets, the rest of the changes are only caused by the guarantee effect. The decreased return on equity ratio reveals that the bank's performance is undervalued, while the Tier I capital ratio increases to $18 /(34+20+36+13)=17,5 \%$.

The two extended balance sheets in figure 5.7 depict the combined measures of guarantees and direct equity injections. Still, the guarantee effect is dominant, because of the sizeable amount that is covered, compared to the capital commitment. The guarantee appears in both extended balance sheets, in the liabilities side for the government and in the asset side for the bank. Bank equity increases by both the guarantee and the equity injection and cash is exchanged with equity to liquidate the banking system. The return on equity ratio is again undervalued because of the sizeable collateralization and the capital ratio of the banking system in this case in this occasion is slightly greater, $20 /(32+20+40+13)=19 \%$. 
Figure 5.6: Balance sheet effect: a combination of a purchase of distressed assets and a guarantee provision (extended balance sheet)

\begin{tabular}{|c|c|c|c|}
\hline \multicolumn{2}{|c|}{ The government } & \multicolumn{2}{|c|}{ The bank } \\
\hline Assets & Liabilities and Net Worth & Assets & Liabilities and Equity \\
\hline $11(-4)$ Cash and deposits & Reserves & $34(+4)$ Cash \& equity holdings & Deposits (interbank \& retail) 35 \\
\hline 20 Government securities & Government securities (held by the public) 3 & 20 Interbank loans $(+)$ & Interbank loans (-) \\
\hline $34(+4)$ Loans & External Debt & $36(-4)$ Credit to third parties & Long - term debt \\
\hline 13 Bank Equity & Explicit Guarantee & 13 Explicit Guarantee & $18(+13)$ \\
\hline 35 Fixed Assets & Net Worth & 10 Fixed Assets & \\
\hline 113 Total Assets & Total Liabilities \& Net Worth & 113 Total Assets & Total Liabilities \& Equity $\mathbf{1 1 3}$ \\
\hline
\end{tabular}

Source: Author's contribution.

Figure 5.7: Balance sheet effect: a combination of a guarantee provision and a direct capital injection (extended balance sheet)

\begin{tabular}{|c|c|c|c|c|c|}
\hline \multicolumn{2}{|c|}{ The government } & \multicolumn{4}{|c|}{ The bank } \\
\hline Assets & \multicolumn{2}{|c|}{ Liabilities and Net Worth } & Assets & \multicolumn{2}{|l|}{ Liabilities and Equity } \\
\hline $13(-2)$ Cash and deposits & Reserves & 10 & $32(+2)$ Cash \& equity hold. & Deposits (interbank \& retail) & \\
\hline 20 Government securities & Goverument securities (held b & public) 35 & 20 Interbank loans $(+)$ & Interbank loans (-) & 20 \\
\hline 30 Loans & External Debt & 40 & 40 Cre dit to third parties & Long - term debt & 40 \\
\hline 15 Bank Equaty & Explicit Guarantee & 13 & 13 Explicit Guarantee & Equity & $+15)$ \\
\hline 35 Fixed Assets & Net Worth & 15 & 10 Fixed Assets & & \\
\hline $113(+13) \quad$ Total Assets & Total Liabilities \& Net Wortl & $113(+13)$ & 115 (+15) Total Assets & Total Liabilities \& Equity 11 & +15) \\
\hline
\end{tabular}

As we observe, if guarantees are combined with other measures, the actual on-balance sheet effects are not detectable. This is also the case in figure 5.8, where we show a combination of all three measures, an asset purchase, a guarantee provision and a direct capital injection. Once more, the dominant effect results from the guarantee, which constitutes the higher commitment. The asset purchase and the capital injection both enhance liquidity, the first by restructuring the asset side of both balance sheets and the latter by exchanging cash with equity capital. The balance sheet totals increase, with the greatest increase to occur in the banking sector. Furthermore, because of the increased capital, the bank efficiency, as measured by the return on equity ratio, seems undervalued. On the contrary, there is an overvaluation of the Tier I capital ratio, which is the same to the case of a mix of guarantees and direct capital injections, that is $19 \%$ $[20 /(36+20+36+13)]$. 
Figure 5.8: Balance sheet effect: a combination of a purchase of distressed assets, a guarantee provision and a direct capital injection (extended balance sheet)

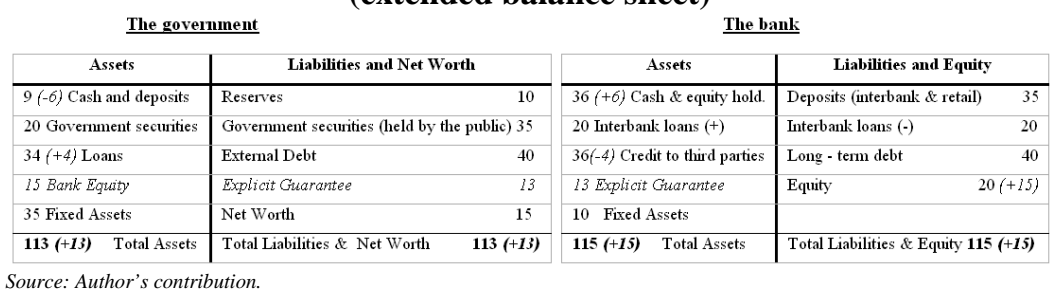

The most interesting case is the mix of a distressed asset purchase and a direct capital injection (figure 5.9). This is the only combination that affects the two conventional balance sheets. The balance sheet totals remain the same for the government and slightly increase for the bank. The dominant effect comes from the capital injections, since with asset purchases, there is only a liquid-illiquid asset exchange. The only reason for increasing balance sheet totals and changes in performance and capital adequacy ratios is the direct cash injection. More specifically, the Tier I ratio is 7,6\% $[7 /(36+20+36)]$, which is the same to the direct capital injection intervention alone. This is rational, since the asset purchase does not affect the capital requirement or the performance ratios. Referring to the latter, the return on equity ratio appears slightly undervalued because of the increased equity.

Figure 5.9: Balance sheet effect: a combination of a purchase of distressed assets and a direct capital injection The government The bant

\begin{tabular}{|c|c|c|c|}
\hline Assets & Liabilities and Net Worth & Assets & Liabilities and Equity \\
\hline $9(-6)$ Cash and deposits & Reserves & $36(+6)$ Cash \& equity & Derosits finterbol-t setvi \\
\hline 20 Govermment secuities & Government securities (held by the public) 35 & holdings & Deposits (miterbank + retall) \\
\hline $34(+4)$ Loans & External Debt & 20 Interbank: loans $(+)$ & Interbank loans $(-)$ \\
\hline 2 Bank Equaty & Net Worth & $36(-4)$ Credit to third parties & Long - term debt \\
\hline 35 Fixed Assets & & 10 Fixed Assets & Equity \\
\hline 100 Total Assets & Total Liabilities \& Net Worth & $102(+2) \quad$ Total Assets & Total Liabilities \& Equity $102(+2)$ \\
\hline
\end{tabular}

The analysis of figure 5.9 directs us to significant arguments. It is obvious that with this mix of interventions, the main goal is to liquidate, since 6 units of cash are transferred 
from the government to the banking system. This liquidity is counterbalanced by a loan purchase and an equity purchase respectively. We can link the above findings to previous studies (Honohan and Klingebiel, 2003, Montgomery, 2005, Laeven and Valencia, 2008, Hoshi and Kashyap, 2009, IMF, 2009d, IMF, 2009e, OECD, 2009c) that governments tend to combine asset and equity side management. However, through the balance sheet analysis we can also provide a solid explanation.

The fact that asset interventions do not directly affect the balance sheet totals, the capital requirement ratio and performance ratios, gives space and flexibility for combining this neutral measure with a more influential one, such as direct capital injections. Another argument is that, by combining asset and equity management, policymakers aim solely at restoring liquidity of the banking sector and not consider solvency or deleverage targets. The latter is mainly realized through liabilities interventions, even though in the contextual analysis (chapter four), we described how, through asset management, governments aim at both liquidating and deleveraging target banks. Finally, another important finding is that the neutrality of interventions heavily depends upon their effect on equity. As we observed, recapitalization in the form of direct equity injections, which mainly targets at liquidating banks, enhances equity capital. This also occurs with other forms of equity management, such as mergers with public institutions, (partial) nationalizations and other forms of acquisition of bank ownership by public bodies. All these measures, because they increase the net position of banks, always tend to undervalue performance ratios, such as the return on equity ratio (increasing the denominator) or to overvalue the capital adequacy requirement, such as the Tier I ratio (increasing the numerator).

We further discuss the theoretical implications of offbalance sheet exposures, macroeconomic shocks and valuation principles. Table 5.1 sums up our main findings of the balance sheet analysis. These concern the effect of different types of interventions on three banking indicators: the balance sheet 
totals, the return on equity as a performance measure and the Tier I ratio as a capital requirement measure. We also indicate the dominant intervention in each case and the respective level of influence on balance sheet indicators.

Table 5.1: Dominant interventions and the effect on balance sheet indicators

\begin{tabular}{|c|c|c|c|c|c|c|}
\hline Intervention & $\begin{array}{c}\text { Dominant } \\
\text { intervention }^{1}\end{array}$ & $\begin{array}{c}\text { Level of } \\
\text { influence }^{1}\end{array}$ & $\begin{array}{c}\text { Government } \\
\text { balance } \\
\text { sheet totals }\end{array}$ & $\begin{array}{c}\text { Bank } \\
\text { balance } \\
\text { sheet } \\
\text { totals }\end{array}$ & $\begin{array}{c}\text { Capital } \\
\text { requirement }\end{array}$ & $\begin{array}{c}\text { Performance } \\
\text { ratio }\end{array}$ \\
\hline Asset & Asset & Medium & Unchanged & Unchanged & Unchanged & Unchanged \\
\hline Liabilities & Liabilities & Low & Increased $^{2}$ & Increased $^{2}$ & Overvalued $^{3}$ & Undervalued $^{3}$ \\
\hline Equity & Equity & High & Unchanged & Increased & Overvalued $^{3}$ & Undervalued $^{3}$ \\
\hline $\begin{array}{c}\text { Asset / } \\
\text { Liabilities }\end{array}$ & Asset & Medium & Increased $^{2}$ & Increased $^{2}$ & Overvalued $^{3}$ & Undervalued $^{3}$ \\
\hline $\begin{array}{l}\text { Asset / } \\
\text { Equity }\end{array}$ & Equity & High & Unchanged & Increased & Overvalued $^{3}$ & Undervalued $^{3}$ \\
\hline $\begin{array}{c}\text { Liabilities/ } \\
\text { Equity }\end{array}$ & Equity & High & Increased $^{2}$ & Increased $^{2}$ & Overvalued $^{3}$ & Undervalued $^{3}$ \\
\hline $\begin{array}{c}\text { Asset / } \\
\text { Liabilities / } \\
\text { Equity } \\
\end{array}$ & Equity & High & Increased $^{2}$ & Increased $^{2}$ & Overvalued $^{3}$ & Undervalued $^{3}$ \\
\hline \multicolumn{7}{|c|}{$\begin{array}{l}\text { Notes: } \\
\text { 1. We assess the level of influence and the dominant intervention on the conventional balance sheets only } \\
\text { (guarantees effect is not considered) } \\
\text { 2. Changes in balance sheet totals refer to the extended balance sheets (guarantees effect is considered) } \\
\text { 3. We assess the effect on capital requirement and the performance ratio considering the guarantees effect } \\
\text { Source: Author's contribution. }\end{array}$} \\
\hline
\end{tabular}

\subsection{Off-balance sheet exposures, asset valuation and macroeconomic shocks}

This section's purpose is twofold. Firstly, by reviewing the literature, it attempts to accentuate that there are wellestablished finance methods to evaluate liability side interventions, namely guarantees. Secondly, through a theoretical approach, it identifies the macroeconomic shock in a bank's balance sheet, as a factor that makes the valuation of a bank's asset (and, therefore, the implementation of asset and equity management) very difficult.

\subsubsection{Option pricing theory and guarantees valuation}

Explicit deposit insurance schemes and loan guarantees were used as an answer to solvency considerations during crisis periods. There is an extensive literature on 
estimating the value of loan guarantees, deposit insurance and other contingent commitments, either for private or public entities. $^{78}$ In the following part, we specifically focus on Merton's approach on valuing contingencies using option valuation techniques.

Robert Merton (1977), in his paper on the application of option pricing to derive the cost of deposit insurance and guarantees, emphasizes that guarantees constitute an explicit liability cost on the guarantor. There are two alternatives for the government when issuing guarantees as measures to recover from the financial crises: a) deposit guarantees and b) loan guarantees. These actions refer to liability side management and asset side management respectively. Since the government is the guarantor, there is an implicit contingent liability on the public side, which - as Merton argues imposes a cost that is similar to an explicit guarantee. He also assumes that deposit guarantees are less expensive and more efficient compared to guarantees on bank loans.

Such contingencies can be viewed and evaluated as a put option (Merton, 1977) and valued using the Black and Scholes option pricing formula (Black and Scholes, 1973). The author considers a simple model where a firm borrows money and promises to pay a specific amount due at a specific date (the maturity date). If the firm defaults then the bondholder has a claim on the firm's assets. At maturity and as long as there is a positive probability that the value of the firm's asset is less than the expected debt payments, then there is a positive default probability for the debt, which is characterized risky. The default probability is the difference between the asset value (at maturity) and the expected debt payments.

A third party guarantee on the above issuance foresees that in the case of the debt-holder's default, the guarantor has to bear the debt payments. The guarantor on his side has to

\footnotetext{
${ }^{78}$ Most representative examples are the works from Acharya and Dreyfus (1989), Crouhy and Galai (1991), Jones and Mason (1980), Pennacchi (1987), Ronn and Verma (1986), Selby et al. (1988), Sharpe (1978) and Sosin (1980).
} 
ensure that the expected guarantee payments should not be greater than the value of the promised payment on the bond issue. For this insurance, the firm has to pay the guarantor a fee that constitutes the cost of the guarantee, which depends on the payoffs to the debt claims at maturity. On one hand, if the value of the assets is greater than the expected payments, then the bondholder receives the promised payment on the bond issue, while the firm's equity-holders the difference in excess of the asset value. On the other hand, if the expected payments are greater than the asset value, the bondholder receives the payment, the equity-holders receive nothing and the guarantor has a negative outflow equal to the excess of the bond payments on the asset value. The guarantor must cover the loss of default in this example. ${ }^{79}$

\subsubsection{The off-balance nature of banks}

The balance sheet is a picture of only a part of the total activities of a bank. It only shows the present and noncontingent transactions. However, banks also engage in offbalance sheet operations. As Dewatripont and Tirole (1993) categorize, there are 3 different types of such operations:

a) Financial operations not linked with granting actual loans

b) Future or contingent loans

c) Interest rate and foreign exchange contracts. ${ }^{80}$

The authors also analyze the factors that can result to bank failures. Apart from increased competition among banks and carte-type agreements, they distinguish two very relevant and up-to-date factors: macroeconomic shocks and riskier activities. The basic aspects of these two variables are the

\footnotetext{
${ }^{79}$ Merton (1977) argues that the above structure is similar to the payoff from a put option. The expected payment corresponds to the exercise price of the option and the asset value to the stock price. In essence, the guarantor has issued a put option on the firm's asset, which gives the right to the firm to sell these assets at the "price" of the expected payments on the bond issue, at the maturity date of the debt.

${ }^{80}$ Boyd and Gertler (1993) emphasize that large financial institutions are much more involved in off-balance sheet operations.
} 
short term borrowing that is transformed into long-term lending, the increased interest rates, the securitization of high quality assets and the explosion of the volume of over-thecounter derivatives transactions.

The literature on off-balance sheet commitments mainly focused on the excessive risk taking as a result of deposit insurance schemes in the framework of capital regulation. Avery and Berger (1991) empirically test for the effect of commitments on loan portfolio risk. They find that a loan commitment results in less project risk exposure chosen by the borrower compared to the riskiness of a spot loan. As such, loan commitments tend to lower the asset portfolio risk. Apparently, this occurs because of the contingent nature of the commitment. The latter, being a contingent liability, results in bank losses if the borrower exercises her commitment option. Even though the bank receives a premium to realize the commitment, still the contingent liability that is generated is not quantified on-balance. As such, expanding loan commitments can result in extensive risk exposure of financial institutions.

\subsubsection{Asset valuation and guarantees exposure}

The different accounting approaches that a bank asset can be treated in terms of either its historical cost or its market value, affects the efficiency of asset management and liabilities management interventions. More specifically, we observe two different accounting approaches in terms of capital requirements: the historical cost approach and the market value approach.

Following Dewatripont and Tirole's (1993) accounting analysis on a bank balance sheet, the capital adequacy is assessed by the Cooke ratio that gives a bank's capital requirement as a percentage of its total risk adjusted assets. Moreover, the balance sheet at the end of period one has the following format: 


\section{Figure 5.10: Bank end-period balance sheet Assets Liabilities and Equity

\begin{tabular}{c|c}
\hline $\mathrm{v}$ & $\mathrm{D}$ \\
$\eta$ & $\mathrm{E}$
\end{tabular}

Source: Dewatripont and Tirole, 1993.

On the asset side of the balance sheet, $\mathrm{v}$ denotes the realized first period profit and $\eta$ is the historical cost (principal value) of the bank's long term assets. D stands for obligations towards depositors (net debt is $\mathrm{D}-\mathrm{v}$ ) and $\mathrm{E}$ is the owner's equity (which according the authors is usually defined as residual). This approach constitutes the historical value accounting. The capital requirement ratio in this case is:

$$
\mathrm{r}=(\mathrm{v}+\eta-\mathrm{D}) / \eta
$$

Historical cost, however, does not capture macroeconomic shocks that may appear in period 1 , like news from the real estate market or from interest rates. These shocks or noise of period 2 income, which is realized in period 1 is denoted by $\varepsilon$. The balance sheet that incorporates the market value of a bank's asset following the model by Dewatripont and Tirole (1993) is as follows:

\section{Figure 5.11: Bank balance sheet including macroeconomic shocks}

\begin{tabular}{c|c} 
Assets & Liabilities and Equity \\
\hline$v+\varepsilon$ & $\mathrm{D}$ \\
$\eta$ & $\mathrm{E}$
\end{tabular}

Source: Dewatripont and Tirole, 1993.

In the balance sheet above, $\varepsilon$ captures the macroeconomic shocks that are still realized and accounted for in period 1 . Market value accounting, compared to historical cost accounting, includes a very volatile control feature under the capital adequacy requirement. The ratio becomes:

$$
\mathrm{r}=(\mathrm{v}+\varepsilon+\eta-\mathrm{D}) / \eta
$$

The market value approach indicates that the allocation of control is sensitive to the noise element. This has two main outcomes: a) with negative macroeconomic shocks, control is automatically transferred to creditors and b) a possible 
increase in net worth can make the controlling parties (either shareholders or creditors) more risk averse and vice versa.

Apart from the control aspect of the two approaches, this distinction is very important in terms of the proper valuation of the assets that are purchased, should governments choose to implement asset management. We argue that the macroeconomic shock element $\varepsilon$ is the unknown factor for the proper market valuation of a distressed asset that is purchased by the government. This noise is actually the difference between the historical (book) value and the market (real) value of the asset and constitutes the source of uncertainty for the government. Therefore, with asset management, it is very complex to measure macroeconomic shocks and, correspondingly, the true (market) value of the asset. Additionally, when the government implements equity side interventions, it has to properly value all the bank's assets that determine the real market value of the firm. This is not easy because of the shock element. However, with guarantees, the maximum exposures are known and their value can be calculated using specific valuation techniques, such as option pricing. In conclusion, guarantees are a better instrument to restore the financial sector compared to asset purchases or equity injections, considering valuation principles.

We emphasize on the main determinants of all these interventions in the chapter that follows. Before doing so, we link the two chapters by briefly describing the responses from the G20 countries, in the current crisis and by introducing the relevant fiscal implications.

\subsection{The G20 response, support costs and the fiscal perspective}

Every banking crisis that occurred during the latest thirty years brought about either significant or minor costs to governments (Laeven and Valencia, 2008). ${ }^{81}$ If the effects were systemically significant, then governments were

${ }^{81}$ The authors find that, since the late 1970s, 112 episodes of systemic banking crises occurred, which affected 93 developed, developing and transition countries. 
burdened by the fiscal costs of the financial system failure. Such costs arise from the extensive use of public funds to heal the banking system, either by supporting major banks' stakeholders (mainly depositors) or in the form of bail-outs.

Table 5.2: Financial support operations and the impact on the government accounts

\begin{tabular}{|c|c|}
\hline Operation & Effect \\
\hline Capital grants & increase in deficit \\
\hline Equity purchases & $\begin{array}{c}\text { increase in public debt (gross), increase in } \\
\text { deficit when government pays in excess } \\
\text { the value of the equity }\end{array}$ \\
\hline Asset purchases / swaps & $\begin{array}{c}\text { increase in public debt (gross), increase in } \\
\text { deficit when government pays in excess } \\
\text { the value of the asset }\end{array}$ \\
\hline Loans & $\begin{array}{c}\text { increase in public debt (gross), reduce } \\
\text { fiscal balance if the government is not } \\
\text { repaid }\end{array}$ \\
\hline Guarantees & $\begin{array}{c}\text { contingent liabilities, constitute a burden } \\
\text { to the fiscal balance and the public debt if } \\
\text { the guarantee is called }\end{array}$ \\
\hline $\begin{array}{c}\text { Associated fees, interest and } \\
\text { dividends }\end{array}$ & $\begin{array}{c}\text { affect the deficit as any other income or } \\
\text { expense }\end{array}$ \\
\hline Central Bank operations & $\begin{array}{c}\text { losses can affect government budget over } \\
\text { time via profit transfers and necessary } \\
\text { recapitalizations }\end{array}$ \\
\hline Source IMF 2009e.
\end{tabular}

Table 5.2 shows the impact of the financial support operations in the government accounts. According to the IMF (IMF, 2009e), government support can have different implications for public debt. The direct operations can result in an upfront rise of government debt, leaving net government worth and public deficit unaffected due to the acquisition of an asset. The use of these assets in the future determines the longrun effect of fiscal balances. The provision of guarantees has an indirect effect on the fiscal accounts, which is similar to contingent liabilities that are borne by the government. The IMF (2009e) categorizes the different fiscal effects depending on the different types of actions; these are portrayed in the table below. 
The short run effects on the crisis are easily distinguishable from the relevant figures. For all G-20 countries the fiscal and debt balances worsened after 2007, with more intense effects on advanced compared to emerging market countries. ${ }^{82}$ Furthermore, the reasons for deterioration were different among countries: while for advanced countries the financial sector support played the most significant role, in the emerging economies the negative effects were a result of declining commodity and asset pricing (IMF, 2009e). Finally, public debt to GDP ratios rose significantly during the last three years, which is mainly attributed to packages of support towards the banking sectors. Table 5.3 shows the actual figures for 2008 and 2009.

Table 5.3: Change in fiscal balances and public debt in the G20 (\% of GDP, difference with respect to previous period)

\begin{tabular}{|c|c|c|}
\hline Country Groups & $\mathbf{2 0 0 8}$ & $\mathbf{2 0 0 9}$ \\
\hline & \multicolumn{2}{|c|}{ Fiscal Balance } \\
\hline Advanced G20 Countries & $-2,3$ & $-3,8$ \\
\hline Emerging Market G20 Countries & $-0,3$ & $-3,2$ \\
\hline G20 Countries & $-1,5$ & $-3,6$ \\
\hline & \multicolumn{2}{|c|}{ Public Debt } \\
\hline Advanced G20 Countries & 4,4 & 10,0 \\
\hline Emerging Market G20 Countries & $-2,0$ & 1,9 \\
\hline G20 Countries & 2,0 & 7,0 \\
\hline Source: IMF 2009e.
\end{tabular}

Beyond direct fiscal costs, the crisis brought indirect effects. The deterioration of the fiscal position and doubts about fiscal solvency can result in rising cost of borrowing. Even though "nominal interest rates have declined since the beginning of the crisis, the weaker fiscal outlook has been relatively muted" (IMF, 2009e, page 30). The real interest rates are nearly the same as in early 2007 , despite expectation of decreases. At the same time, for countries with deteriorated

82 Due to the lower impact growth, automatic stabilizers and fiscal stimulus, according to the IMF. 
fiscal conditions (such as Greece and Italy), spreads have risen, increasing the cost of debt. ${ }^{83}$

\subsection{Concluding remarks}

Emphasizing on the importance of public risk exposure and introducing specific aspects of the crisis for the G20 governments, we proceed to chapter six. There, we propose a decision model that assesses the combination different crisis interventions and analyzes their policy mix. Before doing so, we summarize the main findings of this chapter.

The balance sheet approach revealed important findings. Looking at each intervention group alone, we find that liabilities interventions affect only an extended balance sheet with significant increases in the balance sheet totals for both the bank and the government and a prospective overvaluation of the capital adequacy requirement. Even such, this is the most neutral intervention since it imposes only offbalance sheet effects. On the other side, equity management incorporates the most influential measures. A direct capital injection increases the bank's balance sheet totals through recapitalization, undervalues the return on equity performance ratio and overvalues the Tier I capital ratio. Asset management stands in between, since it affects the two balance sheets only by rearranging their asset structure. The government and the bank exchange liquid with distressed assets. If policymakers combine asset with equity management, then the latter is the dominant intervention and the balance sheet effect is similar to a single direct capital injection. In this case, the main target is to provide the banking system with liquidity, not considering solvency integration. We also argue that interventions, which transform the equity structure of a bank are the most influential, since they significantly affect balance sheet totals, capital requirement indicators and performance ratios.

Asset management raises valuation issues as well. These are revealed through the market value accounting approach that captures the forthcoming period's

${ }^{83}$ Together with increased spreads, there was a concurrent stabilization of bond yields at pre-crisis levels. 
macroeconomic shock. This shock complicates the valuation of a distressed asset and the valuation of the bank as a firm. With guarantees however, the maximum exposure is well known from the beginning. In conclusion, the balance sheet approach and previous literature on asset and liability valuation drives us to a mutual key argument. Liability side interventions (mainly guarantees), given that they are considerably disclosed, are the most neutral, quantifiable and transparent interventions that a government can use against a crisis. 


\section{Assessing government crisis interventions}

\subsection{Introducing the intervention decision process}

\subsubsection{The link with the balance sheet approach}

In the previous chapter, we analyzed the balance sheet outcome for the public and the banking sector, following a specific intervention to overcome the crisis. In this part, we extend the analysis, attempting to unlock the decision box of a government policy action against the crisis. This action varies from doing nothing to implementing a mixture of all three groups of interventions. We use a dataset from the G20 countries that reflects actions and measures that were realized. The dataset includes specific variables, which either capture asset, liabilities or equity management decisions or which are considered to affect directly these actions. The aim is to answer the main research question of the chapter. This question is twofold: a) to observe which variables are important for the decision making process of interventions and b) to investigate how the different interventions affect each other in this process. As such, we have a complete picture of not only the effects (chapter five), but also the basic determinants of the policy decision to intervene.

The remainder of this chapter continues as follows. In section 6.2, we describe the methodology and the data, while section 6.3 includes the economic relationships behind the variables. Section 6.4 contains the steps in the process and the results and, finally, section 6.5 concludes.

\subsubsection{Three steps to unlock the government course of action}

There are three main steps in developing this decision choice analysis. Acknowledging that our dataset is of limited size, we initially use simple descriptive statistics to illustrate how the G20 countries reacted as a whole. To this effect, we use unconditional and conditional probabilities. During the first step, we calculate simple unconditional probabilities to see how many countries on average implemented which intervention. Additionally, we review the direct and indirect 
effect of related variables on each intervention. This process reveals which of the variables are important during the initial governmental decision to intervene using at least one group of measures.

The second step of the estimation deals with a choice of two interventions. Firstly, we statistically describe this choice, calculating unconditional probabilities for a mix of two interventions. Then, given a specific intervention, we calculate the conditional probability of another one. In this way, we indicate when a government decides to intervene with auxiliary measures, given that they have already implemented another measure.

Finally, in step 3, we estimate how many countries, on average, implemented all three different groups of interventions (unconditional probabilities). Given two interventions, we also assess the probability of enforcing another intervention. With this latest step, we cover all possible combinations of intervention decisions that can be applied. $^{84}$

\section{Figure 6.1: Government intervention decision chart}

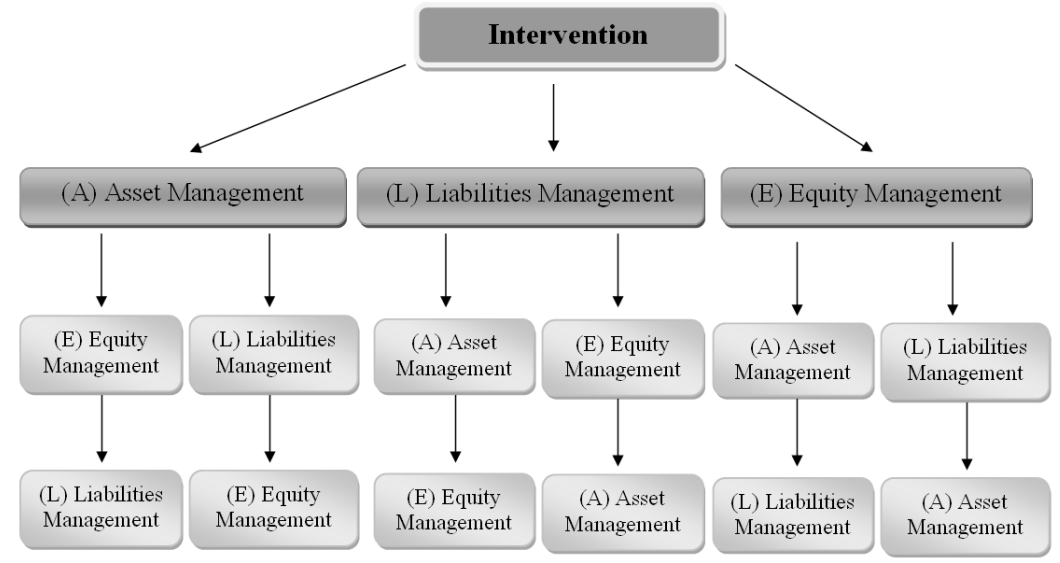

Source: Author's contribution.

84 The terminology used here, conditional versus unconditional probabilities, does not reveal anything about the timing of each respective intervention. 
Figure 6.1 portrays a decision tree with the different government intervention alternatives. This policy mix is the main determinant in the estimation process.

\subsection{The logit model and the dataset}

\subsubsection{The logit model and jackknife}

A logit incorporates a set of regression coefficients that predicts the probability of an outcome of interest (McKelvey and Zavoina, 1975). It constitutes the log of the odds that an event will occur. These are the probability of the event of interest to occur divided by the probability of the event of interest not to occur. Thus, to fit a binary logistic regression model, we estimate a set of regression coefficients that predict the probability of the outcome of interest. The coefficients reveal how much the log odds change based on the values of the predictor variables. Respectively, the logit as a linear combination of parameters is:

$\ln (\mathrm{f}(\chi))=\ln \left(\frac{\operatorname{Pr}(\chi)}{1-\operatorname{Pr}(\chi)}\right)=\mathbf{b}_{0}+\mathbf{b}_{1} \mathbf{X}_{1}+\mathbf{b}_{2} \mathbf{X}_{2}+\ldots+\mathbf{b}_{\mathrm{n}} \mathbf{X}_{\mathrm{n}}+\varepsilon$

In the above equation, $\mathbf{X}_{1}, \mathbf{X}_{2} \ldots \mathbf{X}_{\mathrm{k}}$ are vectors of the predictor variables, $\ln$ is the natural logarithm of the input, $\chi$ is the event, $\mathbf{b}_{1}, \mathbf{b}_{2} \ldots \mathbf{b}_{\mathrm{k}}$ are vectors of the respective parameters and $\varepsilon_{\mathrm{n}}$ the error term. This equation is used for every group of variables as described in the next section.

In a first step of the estimation, we resample our dataset, by using jackknife, in order to predict the logit regressions outcome and the log odds, as the conditional variable varies within a specific range. ${ }^{85}$ Jackknife is a resampling method where estimators are re-estimated several times. We use it in this case, since the determination of our estimation properties is not straightforward. The main reason for that is the small sample size. This distributional inadequacy can be outstripped via jackknife. Without further

${ }^{85}$ The initial idea of jackknife was developed by Quenouille (1949 and 1956) and Tukey (1958), in an attempt to reduce bias and to achieve robust interval estimation. 
information about the distribution of our random variable, we obtain a pseudodatabase from which we calculate values and probabilities estimates. Using jackknife, in this way, allows us to remove bias (Quenouille, 1956). ${ }^{86}$

More specifically, the jackknife is used to estimate three variable coefficients in each of the three different logit regressions in the first step, which reflect asset, liabilities and equity interventions respectively. The aim is to estimate each of these parameters by its sample analogue. This is difficult by definition, since we do not have information about the distribution of the random variable that defines our population. This means that there are no clear theoretical results that can be used to approximate the sampling distribution of our sample analogues or to estimate their standard errors or biases. The jackknife process allows us to overcome this obstacle by estimating jackknifed parameters and by constructing approximate confidence intervals for these parameters.

For step 2, we use continuous variables which capture asset, liabilities and equity interventions for univariate models. More specifically, we use the total amount of asset purchases for asset interventions, the guarantee commitments for liabilities interventions and the direct equity injections for equity management. In this way, the approach is extended to consider actual values and amounts that were committed for the different interventions. Likewise, the above control variables are used in step 3. However, we do not implement jackknife in steps 2 and 3 since it provides us with insignificant coefficients and atypical values.

\subsubsection{The variables and the data}

Table 6.1 shows the intervention decisions for all G20 countries plus Spain and the Netherlands, countries which also participated in the summit. As discussed in chapter four, we have distinguished the different interventions to a) asset management that includes asset purchases, b) liabilities

\footnotetext{
${ }^{86}$ We recognize in this occasion that, even by using jackknife, the small sample size may cause weighting bias to the process of resampling.
} 
management that includes deposit insurance and other guarantees and c) equity management with capitalization and direct equity injections. Some countries did not realize any measures at all, such as Argentina, India, South Africa and Turkey. On the other side, France, Germany, Italy, Russia, Spain, South Korea, United Kingdom and United States imposed measures from all three intervention groups.

Table 6.1: Intervention decisions in the banking sector, G20, Spain and Netherlands

\begin{tabular}{|c|c|c|c|}
\hline Country & $\begin{array}{c}\text { Asset } \\
\text { Management }\end{array}$ & $\begin{array}{c}\text { Liabilities } \\
\text { Management }\end{array}$ & $\begin{array}{c}\text { Equity } \\
\text { Management }\end{array}$ \\
\hline Argentina & No & No & No \\
\hline Australia & Yes & Yes & $\mathrm{No}$ \\
\hline Brazil & Yes & No & No \\
\hline Canada & Yes & Yes & No \\
\hline China & No & No & Yes \\
\hline France & Yes & Yes & Yes \\
\hline Germany & Yes & Yes & Yes \\
\hline India & No & No & No \\
\hline Indonesia & No & Yes & No \\
\hline Italy & Yes & Yes & Yes \\
\hline Japan & Yes & No & Yes \\
\hline Mexico & No & Yes & No \\
\hline Netherlands & No & Yes & Yes \\
\hline Russia & Yes & Yes & Yes \\
\hline Saudi Arabia & No & Yes & Yes \\
\hline South Africa & No & No & No \\
\hline Spain & Yes & Yes & Yes \\
\hline South Korea & Yes & Yes & Yes \\
\hline Turkey & No & No & No \\
\hline United Kingdom & Yes & Yes & Yes \\
\hline United States & Yes & Yes & Yes \\
\hline
\end{tabular}

Source: IMF 2009d.

Three different categories of explanatory variables constitute the dataset, which contains fiscal cost variables, financial sector variables and bank regulation variables. ${ }^{87}$ Table 6.2 shows all the relevant figures. Fiscal cost variables

${ }^{87}$ Appendices 6-A and 6-B (tables 1-5) include all variables and data that we used during the pre-estimation phase for year 2008, while some additional data for year 2007 appear in appendix 6-C (tables 1 and 2). 
are the asset purchases, the guarantees and the capital injections. The financial sector variables are the bank assets and the bank liabilities. Finally, the five remaining variables are part of the Levine et al. dataset (2008) that integrates banking regulation variables. These are: a) the percent of the commercial banking system's assets in central government bonds or other government or central bank securities, b) the fraction of the banking systems loans in banks that are $50 \%$ or more government owned, c) the minimum asset to capital ratio requirement, d) the existence of an explicit deposit insurance protection system and e) the establishment of predetermined levels of solvency (capital or net worth) deterioration, which forces automatic actions (like intervention).

Table 6.2: Fiscal costs, financial sector, bank regulation variables data, G20, Spain and Netherlands

\begin{tabular}{|c|c|c|c|c|c|c|c|c|c|c|}
\hline Country & $\begin{array}{c}\text { Assets } \\
\text { purchases } \\
\% \text { GDP }\end{array}$ & $\begin{array}{c}\text { Guarantees } \\
\% \text { GDP }\end{array}$ & $\begin{array}{c}\text { Capital } \\
\text { injections } \\
\% \text { GDP }\end{array}$ & $\begin{array}{c}\text { Bank } \\
\text { Assets } \\
\% \\
\text { GDP }\end{array}$ & $\begin{array}{c}\text { Bank } \\
\text { Liabilities } \\
\% \text { GDP }\end{array}$ & $\begin{array}{c}\begin{array}{c}\% \text { of } \\
\text { banking }\end{array} \\
\text { system's } \\
\text { assets in } \\
\text { central } \\
\text { government } \\
\text { bonds }\end{array}$ & $\begin{array}{c}\% \text { of } \\
\text { banking } \\
\text { system } \\
\text { loans that } \\
\text { are } 50 \% \text { or } \\
\text { more } \\
\text { government } \\
\text { owned }\end{array}$ & $\begin{array}{c}\text { minimum } \\
\text { capital to } \\
\text { asset ratio } \\
\text { requirement }\end{array}$ & $\begin{array}{c}\text { explicit } \\
\text { deposit } \\
\text { insurance } \\
\text { protection } \\
\text { system }\end{array}$ & $\begin{array}{l}\text { establishment } \\
\text { of } \\
\text { predetermined } \\
\text { levels of } \\
\text { solvency }\end{array}$ \\
\hline Argentina & 0,9 & 0,0 & 0,0 & 0,054 & 0,087 & 0,413 & 0,311 & 0,08 & Yes & No \\
\hline Australia & 0,7 & N/A & 0,0 & 0,314 & 0,129 & N/A & 0 & 0,08 & No & Yes \\
\hline Brazil & 0,0 & 0,0 & 0,0 & 0,097 & 0,041 & 0,21 & 0,45 & 0,11 & Yes & No \\
\hline Canada & 8,8 & 11,7 & 0,0 & 0,243 & 0,119 & 0,067 & $\mathrm{~N} / \mathrm{A}$ & 0,08 & Yes & No \\
\hline China & 0,0 & 0,0 & 0,5 & 0,035 & 0,054 & N/A & 0,66 & 0,08 & No & No \\
\hline France & 1,3 & 16,4 & 1,2 & 0,633 & 0,401 & 0,019 & 0,006 & N/A & Yes & No \\
\hline Germany & 0,4 & 17,6 & 3,7 & 0,477 & 0,574 & 0,014 & 0,402 & 0,08 & Yes & Yes \\
\hline India & 0,0 & 0,0 & 0,0 & 0,111 & 0,037 & 0,314 & 0,726 & 0,09 & Yes & No \\
\hline Indonesia & 0,0 & 0,1 & 0,0 & 0,114 & 0,027 & 0,270 & 0,392 & 0,08 & Yes & Yes \\
\hline Italy & 0,0 & 0,0 & 1,3 & 0,499 & 0,142 & 0,05 & 0,101 & 0,08 & Yes & No \\
\hline Japan & 6,7 & 3,9 & 2,4 & 0,136 & 0,176 & 0,118 & N/A & 0,08 & Yes & Yes \\
\hline Mexico & 0,0 & 0,2 & 0,0 & 0,094 & 0,084 & 0,143 & N/A & 0,08 & Yes & Yes \\
\hline Netherlands & 2,8 & 33,7 & 3,4 & 1,499 & 1,037 & 0,103 & 0,051 & 0,08 & Yes & No \\
\hline Russia & 0,4 & 0,5 & 0,1 & 0,108 & 0,078 & 0,05 & 0,413 & 0,11 & Yes & Yes \\
\hline Saudi Arabia & 0,6 & N/A & 0,6 & 0,162 & 0,376 & 0,187 & 0,18 & 0,08 & No & No \\
\hline South Africa & 0,0 & 0,0 & 0,0 & 0,129 & 0,159 & 0,054 & N/A & 0,10 & No & Yes \\
\hline Spain & 4,6 & 18,3 & 0,0 & 0,687 & 0,195 & 0,046 & 0 & 0,08 & Yes & Yes \\
\hline South Korea & 1,2 & 10,6 & 2,5 & 0,196 & 0,061 & N/A & 0,143 & $\mathrm{~N} / \mathrm{A}$ & Yes & Yes \\
\hline Turkey & 0,0 & 0,0 & 0,0 & 0,195 & 0,089 & 0,387 & N/A & 0,08 & Yes & Yes \\
\hline United Kingdom & 13,8 & 17,4 & 3,5 & 1,873 & 1,706 & 0,2 & N/A & 0,08 & Yes & No \\
\hline \multirow[t]{2}{*}{ United States } & $\begin{array}{l}6,0 \\
\end{array}$ & 31,3 & 4,0 & 0,371 & 0,285 & 0,119 & 0 & 0,08 & Yes & Yes \\
\hline & $\begin{array}{l}\text { ources: IMF } 2 \\
009, \text { African E } \\
\text { ettlements (BIS } \\
\text { lotes:1. Figures } \\
\text { Japan's \% of } \\
\text { re not included } \\
\text { United Kingd, } \\
\text { he Central Ban } \\
\text { Russia's mini } \\
\text { est } \\
\text { Reserve Bank } \\
\text { hyisaged with }\end{array}$ & $\begin{array}{l}\text { e, Bendeich, } 2 \\
\text { omic Outlook, } \\
\text { Ooogb, Levine e } \\
\text { rfinancial sect } \\
\text { nmercial banki } \\
\text { this figure } \\
\text { 's \% of commer } \\
\text { m capital to ass }\end{array}$ & 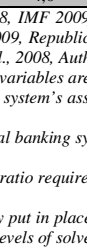 & $\begin{array}{l}\text { Indones } \\
\text { scalcull } \\
\text { lculated }\end{array}$ & $\begin{array}{l}2 k \text { of Argentin } \\
2009, \text { OECD } \\
\text { ons. } \\
\% \text { GDP in cu } \\
\text { government bo } \\
\text { n central gove } \\
\text { r banks with o } \\
\text { rective Action } \\
\text { ion. }\end{array}$ & $\begin{array}{l}\text { 2009, Banco C } \\
\text { oog, Saudi Arc } \\
\text { nt prices in bill } \\
\text { ls is calculated } \\
\text { ment bonds inc } \\
\text { nfunds less tha } \\
\text { PCA) framewor }\end{array}$ & $\begin{array}{l}\text { ral Do Brazil, } \\
\text { n Monetary A, } \\
\text { of U.S. dollar } \\
\text { f end March } 2 \\
\text { es T-Bills and } \\
\text { uble equivalen } \\
\text { nder which cer }\end{array}$ & $\begin{array}{l}\text { 09, Central Int } \\
\text { cy, 2009, Bank } \\
\text { MF, 2009f) } \\
6 . \text { The branches } \\
\text { s and excludes } \\
\text { f } 5 \text { million euro } \\
\text { interventions }\end{array}$ & $\begin{array}{l}\text { igence Agency, } \\
\text { r International } \\
\text { fforeign banks } \\
\text { edit unions and } \\
\text { ind } 10 \% \text { for the } \\
\text { supervisor are }\end{array}$ & \\
\hline
\end{tabular}

Since guarantees are of prime interest throughout this thesis, it is worthwhile to mention how and to what extend financial institutions actually used these measures. More 
importantly, these disclosed amounts can serve as a direct $e x$ post proxy of the riskiness of banks. As the IMF states (IMF, 2010), the uptake for guarantees were marked as less than pledged for the G20 countries. Some examples (data until the end of 2009) are representative. ${ }^{88}$ German financial institutions have used guarantees amounting to $9.9 \%$ of GDP, whereas the total commitment was 17,6\%. Similarly, France utilized 5,8\% of GDP from a commitment of 16,4\%, while Spain used $4,8 \%$ out of $18.3 \%$. For the same period Dutch financial institutions took advantage of $13,7 \%$ from a pledged guaranteed amount of 33,7\% (ECB, 2010). Generally, for all the measures, the amount of financial support was much less than the committed amounts (IMF, 2010).

We observe from the primary data, that some countries choose either not to intervene at all or to commit only a small portion of their GDP to resolution measures. ${ }^{90}$ China and Italy fall into the caveat of realizing only direct capital injections. In this way, their policy decision-makers fail to recognize many negative externalities of equity side management. Similarly, Japan, Saudi Arabia and Russia, even if they also utilize more neutral interventions such as guarantees and asset purchases, ${ }^{91}$ they clearly focus on capital injections. This is because a significant share of the total commitments, compared to the other countries, were directed to bringing in "fresh" capital. On the other side, Argentina and Australia followed a most neutral resolution, purchasing bank assets with a relatively small proportion of their GDP.

The rest of the countries implemented a balanced intervention policy. The shares of the different measures for France and Germany are similar, where most of the

\footnotetext{
${ }^{88}$ Data retrieved from a European Central Bank occasional paper (ECB, 2010). The amounts are shown as a percentage of 2009 GDP.

${ }^{89}$ The amount that was used for capital injections and asset purchases (average G20) until December 2009 was 51,7\% and 60,2\% respectively on the initial commitment (IMF, 2010).

${ }^{90}$ These countries are Brazil, India, Indonesia, Mexico, South Africa and Turkey.

${ }^{91}$ With the exception of Saudi Arabia who does not guarantee any bank liabilities.
} 
commitments concern guaranteed liabilities. Germany devoted a slightly higher percentage of its GDP to support its bail-out package which foresaw capital injections into banks and insurance companies to back up the guarantee program. South Korea and the United Kingdom fall more or less on the same track, while the latter devoted more sizeable amounts, especially to asset purchases and treasury lending. The share of the commitments is similar for the United States and the Netherlands, with an obvious focus on guarantee schemes. Even if the two administrations (and central banks) initiated emergency measures as well, they aimed basically at expanding credit guarantees for interbank lending to ease liquidity constraints. However, the overall committed funds constitute a significant portion of the GDP, burdening the fiscal accounts and increasing the public risk exposures. ${ }^{92}$

Finally, Canada and Spain seem to the overcome the distortions caused by equity management, employing only asset purchases and guarantees. The two countries, through guarantee schemes, ensure a positive and prompt response to any possible threats or unforeseen events that could affect their financial system. They provide flexible options to face banking system difficulties when they emerge and means to support systemically significant financial institutions in terms of raising regulatory capital and providing liquidity. Summing up, the two countries efficiently managed to safeguard the (ex post) vulnerable positions of their financial institutions. ${ }^{93}$

\subsubsection{The ordered logit model}

Before utilizing the three-step process as described above, we applied an ordered logit model (Greene, 1990). The model assumes a natural ranking in the possible value of the dependent variable. The ordinal dependent variable

\footnotetext{
${ }^{92}$ United States, United Kingdom and the Netherlands commit the highest percentage of their GDP towards the total actual and contingent cost of interventions among the G20.

${ }^{93}$ Canada, especially, did more than surviving the financial crisis. This is because Canadian banks are well capitalized all-round organizations, while the "investment bank" as a concept does not exist.
} 
incorporates the different interventions as introduced in chapter four: asset management, liabilities management and equity management. We scale countries, which implemented all three different measures as of higher rank (3), then countries that mix 2 out of the three interventions (2), then countries who implemented only one type of intervention (1) and lastly countries that did not intervene (0).

The regression results show that the variables total support costs, capital injections and the percentage of banking system assets on government bonds are statistically significant. Total support costs have a positive coefficient. ${ }^{94}$ This is in line with previous literature (Honohan and Klingebiel, 2003, IMF, 2009h, Laeven and Valencia, 2008) that finds a positive relationship between total support costs and increased level of interventions. Extensive funding commitments are more likely to drive the governments into realizing an extended mix of measures. However, we argue that if governments decide to increase fiscal commitments, they usually aim at specific interventions (usually a combination of two measures) and not at a more generalized scheme. $^{95}$

A negative relationship between government securities (as a percentage of banking system assets) and the ordinal intervention variable is also accentuated. ${ }^{96}$ The results reveal the inflexibility of the government to combine auxiliary liability and equity side measures. It is also proved that increased level of government bonds can only achieve limited

\footnotetext{
${ }^{94}$ More precisely, the proportional odds ratio for a one unit increase in the total support score on the intervention level is 0,11 . This means that for a one unit increase in the total support score, the odds of more interventions (combined to lower level of interventions) are 0,11 greater given that government balance and public debt are held constant.

95 This is enhanced by the results on the ancillary parameters, which differentiates low and medium number of interventions $(0,1$ or 2 interventions) from high number of interventions ( 3 interventions).

96 The negative proportional odds ratio of $-17,56$ for the percentage of banking system assets on government bonds, indicates that a one unit increase in this percentage, causes a 17,56 unit decrease in the odds for greater mix of interventions (should asset purchases and government bonds are held constant in the model).
} 
and targeted results, mainly concerning asset side policies. The negative coefficient shows that if the banking system asset volume is heavily constituted of government securities, then governments are directly driven to implement single asset side remedies.

Finally, with capital injections, governments are more likely to implement an extended combination of measures with additional asset and liabilities management policies. ${ }^{97}$ This is because capital injections must be accompanied by asset (asset loss provisions) and liability (deposit insurance schemes) guarantees, in order to achieve liquidity and solvency integration in the banking system. Our results fortify the findings of previous studies (La Porta et. al., 2000, Honohan and Klingebiel, 2003, Hoshi and Kashyap, 2009, Montgomery, 2005) that capital injections are concurrently used with other asset and liability management interventions such as guarantees and asset purchases.

Even if the above findings are interesting for interpreting the variety of the intervention mix, they do not reveal the decision to choose a specific intervention, conditional on another intervention or a relevant control variable. It seems like binary and ordered outcomes cannot explain conditionality of interventions sufficiently. ${ }^{98}$ The ordered logit model estimates the probability of implementing a wider variety of interventions, but it cannot isolate, which specific interventions are realized to this respect. To analyze that, we proceed to the three-step process. Before doing so, we describe the relationship between each explanatory variable and the intervention choice.

\footnotetext{
${ }^{97}$ A one unit increase in capital injections results in an increase of 0,95 in the log odds of more interventions, if the capital ratio and the solvency target remain unchanged.

${ }^{98}$ Additionally, due to the small sample size, binary and ordered outcomes result in insignificant and atypical values.
} 


\subsection{The economic rationale behind the variable relationships}

\subsubsection{Asset management variables}

The variables in question are linked with the government's policy decision to implement asset interventions. The sign of the respective coefficients indicates the relationship (positive or negative) between each variable and the choice of asset intervention as the dependent variable. The logit model for this group of explanatory variables is:

$$
\ln (\mathrm{f}(\chi))=\ln \left(\frac{\operatorname{Pr}(\chi)}{1-\operatorname{Pr}(\chi)}\right)=\boldsymbol{\beta}_{0}+\boldsymbol{\beta}_{\mathrm{n}}{ }^{\prime} \mathbf{Y}_{\mathrm{n}}+\varepsilon_{\mathrm{n}}
$$

In equation $6.2, \mathrm{Y}_{\mathrm{n}}$ is a vector for each explanatory variable, $\chi$ is the event, $\boldsymbol{\beta}_{0}$ is the logit regression coefficient, $\boldsymbol{\beta}_{\mathrm{n}}$ is a coefficient vector of the explanatory variable and $\varepsilon_{\mathrm{n}}$ the error term.

\section{a) Purchases of distressed assets}

This variable is used as an explanatory variable in step 1 and as a control variable, indicating the exact level of asset purchases in steps 2 and 3 . We clearly expect a positive coefficient for step 1, since a higher volume of funds committed to asset purchases is more likely to result in implementing asset intervention measures. Additionally, empirical findings have shown that with asset purchases, comes a decision for choosing a mixture of other asset-side measures. Hoshi and Kashyap (2009) stress similarities between asset and equity management, both in terms of lack of capital (for purchasing distressed assets and removing them from the banks' balance sheets) and also the concurrent use of public funds for recapitalization. Asset purchases were combined in numerous occasions (Laeven and Valencia, 2008) with loan guarantee protection, indicating that increased volume of asset purchases are mixed with other asset interventions as well.

\section{b) Explicit deposit insurance protection system}

Even if deposit protection refers to safeguarding bank liabilities and guarantee provisions literally include measures for deposit insurance, we consider that the existence of an 
explicit deposit insurance protection system affects directly the decision of the government to implement asset interventions. The reason for this is twofold. Firstly, the focus of such a scheme on depositors can enhance liquidity on the asset side of a bank's balance sheet, since these "protected" funds are used to finance many banking activities. ${ }^{99}$ Secondly, the decision to implement asset interventions heavily depends on the pre-existence of deposit protection before the crisis. ${ }^{100}$ If the latter already exist, it is more likely that governments focus more on liquidity provisions, such as asset purchases, rather than extending deposit protection even more. This reveals our argument on the expected coefficient. Deposit protection ex ante, is more likely to increase the probability of implementing asset interventions, resulting in a positive coefficient.

\section{c) Bank assets to GDP}

The variable "bank assets of the financial sector as a percentage of GDP" is closely interrelated to asset purchases, which is the control variable for the asset interventions. A high level of bank assets is more likely to be accompanied by large volume of purchases of some of these assets, namely the ones that are distressed. Moreover, extensive concentration of bank assets in the financial system is linked to greater instability of the banking sector. ${ }^{101}$ If the primal objective of governments is the restoration of the financial system, then greater amounts committed to asset purchases schemes will be

\footnotetext{
99 As Schich (2008) emphasizes, after the trouble of large investment banks, there was an accelerated loss of confidence, which was reflected in the rapid decrease of prices of risky assets. At the same time, the demand, and therefore the prices, for assets with either explicit or implicit insurance hiked. The aim was that, through the provision of this high credit quality instruments, the governments would provide a stable source of financing and reduce the threat of bank failure.

100 For example, Honohan and Klingebiel (2003) mention that an accommodating approach features - among others - liquidity support to banks and explicit blanket depositor guarantees.

${ }^{101}$ La Porta et. al. (2000) use the volume of bank assets as an indicator of the banking sector efficiency. They also include bank assets in the measurement of financial stability and find that bank assets are related with grater financial instability.
} 
necessary. Thus, we expect a positive relationship between bank assets and the asset intervention variable as measured with asset purchases.

\subsubsection{Liabilities management variables}

This group is related to the choice of liability interventions. In the section to follow, we explain the relationship between each of the explanatory variables and the dependent variable, this being the liabilities intervention choice. The logit regression is:

$$
\ln (\mathrm{f}(\chi))=\ln \left(\frac{\operatorname{Pr}(\chi)}{1-\operatorname{Pr}(\chi)}\right)=\gamma_{0}+\gamma_{\mathrm{n}}{ }^{\prime} \mathbf{Z}_{\mathrm{n}}+\varepsilon_{\mathrm{n}}
$$

$\mathrm{Z}_{\mathrm{n}}$ is a vector for each explanatory variable, $\chi$ is the event, $\gamma_{0}$ is the logit regression coefficient, $\gamma_{\mathrm{n}}$ the parameter of the explanatory features and $\varepsilon_{\mathrm{n}}$ the error term.

\section{a) Guarantees}

In step 1 we use guarantees as an explanatory variable for liabilities interventions, while in steps 2 and 3 we use it as a control variable. Guarantee provision is one of the tools available for governments, mainly used to restore the confidence of the investors and depositors towards the financial market. During the current crisis, governments went beyond the usual support measures, expanding existing guarantee schemes and introducing additional measures for banks, which cannot fulfil their (short-term) obligations. Government guarantees have been made available among other tools to support the issuance of new bank bonds by qualifying financial institutions, with the government guaranteeing the due payment of principal and interest payable by the issuer to the holders of the liabilities covered by the scheme. It is reasonable to expect a positive relationship between the total guarantee commitments and the liabilities intervention variable, since it is more likely that with extended commitments, governments increase liability side measures. ${ }^{102}$

102 Previous literature (OECD, 2009c, Schich, 2008, Honohan and Klingebiel, 2003) deduces that guarantees are concurrently used with other actions to assist troubled financial institutions, such as asset acquirements 
b) Fraction of the banking systems loans in banks that are $50 \%$ or more government owned

The ownership of banking system loans by government appointed bodies reveals the level of the public credit risk exposure. For example, if the government purchases loans form a commercial bank, there is a relevant transfer of credit risk towards the public sector. As the existence of a credit protection system affects the decision of the government to implement asset interventions, the dependence of interbank lending on government ownership directly influences liability side measures. This is because bank asset public ownership may drive governments to implement mainly asset interventions and does not give flexibility to extend liability management.

Additionally, there is another link. Liabilities management, apart from deposit protection, refers to other debt guarantees, guarantees on principal and interest and the like. Thus, the amount of loans that are owned by public bodies, directly affects the decision to extend guarantees to debt instruments and features (principal and interest). The greater the government loan ownership, the less the funds that will be committed to such additional guarantees, since a great percentage of the loans is already "collateralized" through public ownership. As such, we argue that if there is a sizeable portion of government owned loans in the banking system, it is less likely that governments will implement liabilities interventions. Thus, we expect a negative coefficient.

c) Bank liabilities to GDP

The bank liabilities to GDP ratio reveals the highly leveraged positions of financial institutions. We argue that a high volume of banking system liabilities, is more likely to increase the probability of liability side interventions. This is because the complexities that arise when evaluating the contingent obligations of banks, limit the efficiency of solitary one sided interventions. It is more likely that, with highly

(asset management) and direct capital grants (equity management). Apart from loan support actions (guarantees on principles and interest), guarantee schemes typically incorporate deposit protection. 
leveraged positions, extensive liability interventions can address the multiplicity of the problem. Furthermore, specific aspects of the financial crisis are attributed to excess leverage of financial (as well as industrial) entities. Higher levels of capital and consequently less leverage can be more effective than a reduction in capital requirements, resulting in a more resilient financial system. ${ }^{103}$ This is another indication that liabilities management must be extended in order to reduce leverage ex post and to stabilize the banking system. We, therefore, expect a positive coefficient.

\subsubsection{Equity management variables}

These variables are expected to affect the equity intervention variable. We further discuss the expected sign of each coefficient separately. The logit model for this group is:

$$
\ln (\mathrm{f}(\chi))=\ln \left(\frac{\operatorname{Pr}(\chi)}{1-\operatorname{Pr}(\chi)}\right)=\delta_{0}+\boldsymbol{\delta}_{\mathrm{n}}{ }^{\prime} \mathbf{W}_{\mathrm{n}}+\varepsilon_{\mathrm{n}}
$$

where $\mathrm{W}_{\mathrm{n}}$ is a vector for each explanatory variable, $\chi$ is the event, $\boldsymbol{\delta}_{0}$ is the logit regression coefficient, $\boldsymbol{\delta}_{\mathrm{n}}$ the respective parameter and $\varepsilon_{\mathrm{n}}$ the error term. For steps 2 and 3, we also use the total amount of direct capital injections as a control variable for equity interventions. ${ }^{104}$

\section{a) Minimum capital to asset ratio requirement}

In order to maintain the capital adequacy requirements in crisis periods, banks can use supplementary risk adjusted weighted assets or capital. Thus, by definition, equity-side management directly affects the capital ratio. We already

\footnotetext{
103 According to the OECD (2009c), high leverage and a concurrent mismatch between liquid liabilities (in the short term) and illiquid assets (in the long term) can render the entire financial system as vulnerable. Breitenfellner and Wagner (2009) also note that the fact that many highly leveraged financial institutions relied heavily on short term financing, boosted the crisis.

${ }^{104}$ Previous literature (Honohan and Klingebiel, 2003, Montgomery, 2005, Hoshi and Kashyap, 2009) indicates that governments always tend to combine capital injections with other asset side and liability side measures to re-stabilize the banking system. We test these findings in steps 2 and 3 where we use capital injections as a conditional variable for asset and liabilities interventions.
} 
discussed in previous parts, how, through equity injections, the capital adequacy ratio can be overvalued. Governments are tempted to use this tool of (indirect) regulatory forbearance, in order to maintain the required capital requirements by financial institutions at acceptable standards. ${ }^{105} \mathrm{We}$ argue that a banking system with institutions that fulfil the capital regulation criteria adequately, is not in an immediate need for direct equity injection programs. If banks maintain a very high capital adequacy level, it is less likely that the government will commit funds for equity restoration. ${ }^{106}$ As such, we expect a negative coefficient between the capital requirement ratio and the probability of implementing equity side interventions.

b) Percent of the commercial banking system's assets in central government bonds or other government or central bank securities

The variable is linked to the capital adequacy ratio, since it constitutes the percentage of government securities over the total financial assets of banks, which is the denominator in the ratio. Thus, it significantly affects the decision of the government to intervene via equity management measures. Government bonds constitute an important component of the bond market by providing a benchmark yield curve and by assisting in the establishment of the overall credit curve of the financial system. They are typically backed up by government credit and not by physical or financial assets. A well-developed government securities market can enhance financial stability and improve financial intermediation. ${ }^{107}$

\footnotetext{
105 Montgomery (2005) notes, however, that even if troubled recipient banks received significant amounts of capital injections, they faced severe difficulties in maintaining the $8 \%$ capital to asset ratio requirement during previous crisis incidents. Levine et al. (2001), finds that, even if the relationship between stringent capital requirements and the likelihood of a crisis is not very strong, still bank capital is a significant determinant of bank fragility.

${ }^{106}$ Honohan and Klingebiel (2003) also stress that a higher financial strength of banks decreases the probability of intervention.

107 According to the World Bank and the IMF (2001), it can help in the evolvement of new financial products expanding the role of commercial
} 
However, even though the prominent development of the financial bond market could favour the financial system as a whole, the excessive reliance on the banking system could be costly and risky for both government and investors. ${ }^{108}$ Practically, the aim of expanding the government securities market through increased number of issued government bonds seems difficult to materialize. This limits the ability of the government to implement equity side tools. As such, we argue that the volume of government bonds as a percentage of bank assets is negatively linked to equity interventions. Most likely, increased volume of government securities transactions seems to favour asset interventions. Since the variable is not correlated to the general goal of re-stabilization of the financial system as a whole, we can argue that boosting the transactions of government bonds can only achieve limited and targeted results (mainly concerning asset side policies). Thus, we expect a negative relationship.

c) Establishment of predetermined levels of solvency (capital or net worth) deterioration which forces automatic actions (like intervention)

This is a dummy variable, which reveals the regulatory provision for automatic actions, if there is some corrosion in capital adequacy of financial institutions. Therefore, it is directly linked with equity management. A scheme for automatic interventions for insolvency reveals a strong accommodating prudential environment. We argue that it is more likely for a government to intervene extensively - using more equity interventions - if a solid regulatory framework already exists. As such, equity interventions can be positively linked to a provision for automatic actions for predetermined levels of solvency deterioration. ${ }^{109}$

banks to the capital markets and can assist in better completion and intermediation of credit supply.

108 There are many cases were financial institutions keep a high risk-free deposit rate margin. Thus, they do not use financial market transmission channels to sale them to individual investors.

${ }^{109}$ Honohan and Klingebiel (2003) find that the probability of intervention is a function of the net worth and the regulatory policy stance. They deduce that a weaker policy stance decreases the probability of intervention. 


\subsection{The steps in the process and the results}

\subsubsection{Step 1: Unconditional and conditional probabilities of one intervention}

In this step we calculate the unconditional probabilities of a certain type of intervention and the conditional probabilities of each type of interventions given specific explanatory variables. The unconditional probabilities for asset interventions, liabilities interventions and equity interventions are shown in table $6.3 .57 \%$ of the countries $(12$ out of 21) implemented asset and equity management, while $67 \%$ of the countries (14 out of 21) applied liabilities management measures.

Table 6.3: Unconditional probabilities of one intervention

\begin{tabular}{|c|c|c|}
\hline Intervention & Observations & Probability \\
\hline Asset management & 12 & 0,571 \\
\hline Liabilities management & 14 & 0,667 \\
\hline Equity management & 12 & 0,571 \\
\hline
\end{tabular}

We run the jackknifed version of the logit regression to calculate the log of the odds and the respective probabilities of each intervention separately, given specific levels of explanatory variables. The logit regression coefficients are shown in table 6.4. The coefficients, which exhibit the expected sign and are significant are in bold and the ones exhibiting the expected sign but are not significant are in italics. ${ }^{110}$ Four variables overall are significant: the existence of deposit protection for asset management, the guarantees and the fraction of government owned loans for liabilities management and the percentage of government bonds on bank assets for equity management. ${ }^{111}$

\footnotetext{
110 The significance level, the standard errors and the expected sign for each regression are shown in table 1 of appendix 6-D.

${ }^{111}$ Guarantees is a control variable that captures the liabilities interventions and asset purchases a control variable for asset interventions. They are used in steps 2 and 3 of the process, together with capital injections, which perfectly predict the equity intervention variable. Guarantees are found to be significant for liabilities management, but asset purchases are not
} 
Table 6.4: Logit regression results for one intervention

\begin{tabular}{|c|c|}
\hline \multicolumn{2}{|c|}{ Variables related to asset interventions } \\
\hline & Coefficient \\
\hline asset purchases & 0,606 \\
\hline deposit protection & $1,705 *$ \\
\hline bank assets & 1,171 \\
\hline \multicolumn{2}{|c|}{ Variables related to liabilities interventions } \\
\hline & Coefficient \\
\hline guarantees & $\mathbf{0 , 3 0 5 * *}$ \\
\hline government ownership of loans & $-12,416 * *$ \\
\hline bank liabilities & 10,232 \\
\hline \multicolumn{2}{|c|}{ Variables related to equity interventions } \\
\hline & Coefficient \\
\hline capital ratio & $-38,626$ \\
\hline government bonds & $-12,635 *$ \\
\hline solvency target & $-0,223$ \\
\hline
\end{tabular}

The coefficients show the effect of each explanatory variable on the probability to implement each intervention. More precisely, the existence of deposit protection is expected to increase the $\log$ odds of the asset intervention by 1,7 . Likewise, a one unit increase in guarantees increases the log odds for liabilities management by 0,3 and a one unit increase in the percentage of government owned loans decreases the $\log$ odds for liabilities management by 12,4 . Moreover, a one unit increase in the percentage of government securities on bank assets is expected to result in a 12,6 decrease in the log odds of implementing equity interventions.

We present these significant variables graphically in figure 6.2. The signs of each significant coefficient coincide with the economic interpretation that we developed in the previous part. The existence of deposit protection leads governments to focus more on liquidity provisions through asset purchases. Furthermore, increased guarantee commitments are expected to increase the probability of liabilities interventions, while significant public ownership of

significant for asset management. The reason is that the latter, except from plain asset purchases, includes lending by treasury as well. In any case, it is the closest representative continuous variable for asset interventions. 
bank loans does not give much space for extending liabilities management even more. Finally, a banking system that is heavily depended upon government securities drives governments to avoid equity management interventions. ${ }^{112}$

Figure 6.2: Probabilities and confidence intervals for significant variables (one intervention)
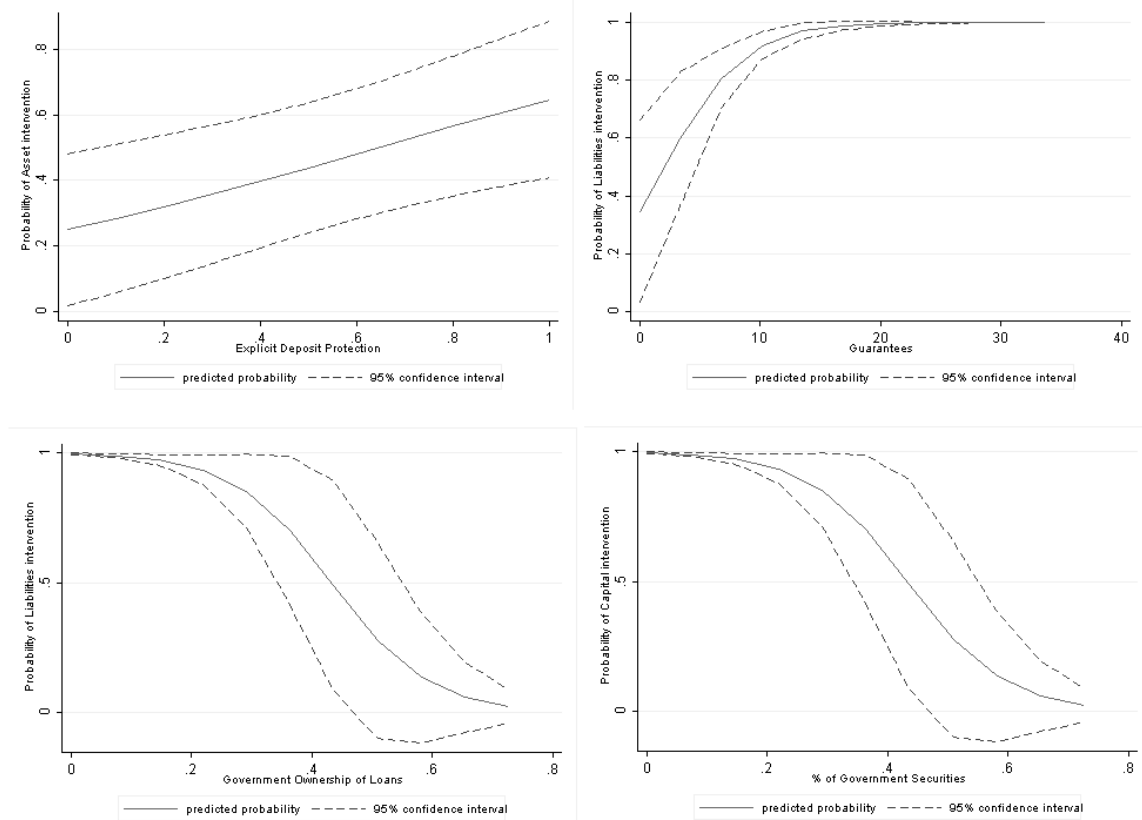

Source: Author's contribution

The confidence intervals reveal the certainty equivalent for specific levels of the explanatory variable. More specifically, given sizeable guarantee commitments, it is almost certain that governments implement liability-side interventions. Even more interestingly, the latter will be certainly realized for low percentages of government owned bank loans. Likewise, if the banking system does not depend on government bonds or other central bank securities, then the

\footnotetext{
112 The smooth equivalent of the log odds above is included in figure 1 of appendix 6-D. It shows the conditional probabilities and the confidence intervals for all the values for the significant variables of the logit regressions.
} 
probability to implement equity-side management, for example direct equity injections, is very high. Finally, since deposit protection is a dummy variable, we only consider the threshold values, 0 and 1 . As we observe from the graph, the confidence intervals are similar for these extreme values, meaning that the probability not to implement asset interventions when there is no deposit protection is similar to the probability of utilizing asset interventions when deposit protection exists ex ante.

Even though we use bank assets and bank liabilities as a percentage of GDP for asset management and liabilities management interventions (the variables are found to be insignificant for both regressions), we observe that they are significant for equity interventions. The difference between bank assets and bank liabilities reveals the net worth level of the banking system and indicate its equity position. In figure 6.3 , we plot the probabilities and confidence intervals for bank assets and bank liabilities with the equity injections as the dependent variable. We note a positive relationship for both regressions and the relationship is even stronger for high levels of bank assets and liabilities. ${ }^{113}$ This means that with sizeable exposures of the banking system, there is a high probability that governments implement equity interventions.

We also introduce a third relevant variable for asset interventions, which is closely related to the existence of an explicit deposit protection system. This is the insurance of liabilities beyond any explicit deposit insurance scheme. ${ }^{114}$ It is a complementary measure for existing deposit protection schemes and reveals the need for additional insurance of liabilities in the banking system. As with deposit protection, this variable is positively related with the probability of asset interventions. ${ }^{115}$ We observe from the graph that it is more

113 The coefficients are $6,81 * *$ for bank assets and $15,84 * *$ for bank liabilities.

${ }^{114}$ This extra deposit protection is granted from the supervisory agency or any other government agency regarding bank restructuring and reorganization.

${ }^{115}$ The coefficient for the insurance of liabilities beyond any explicit deposit insurance scheme is $1,46^{* *}$. 
certain to implement asset-side measures when there exists additional liability insurance, compared to the probability of not implementing asset interventions when there is no liability insurance beyond explicit deposit protection.

Figure 6.3: Probabilities and confidence intervals for related variables (one intervention)
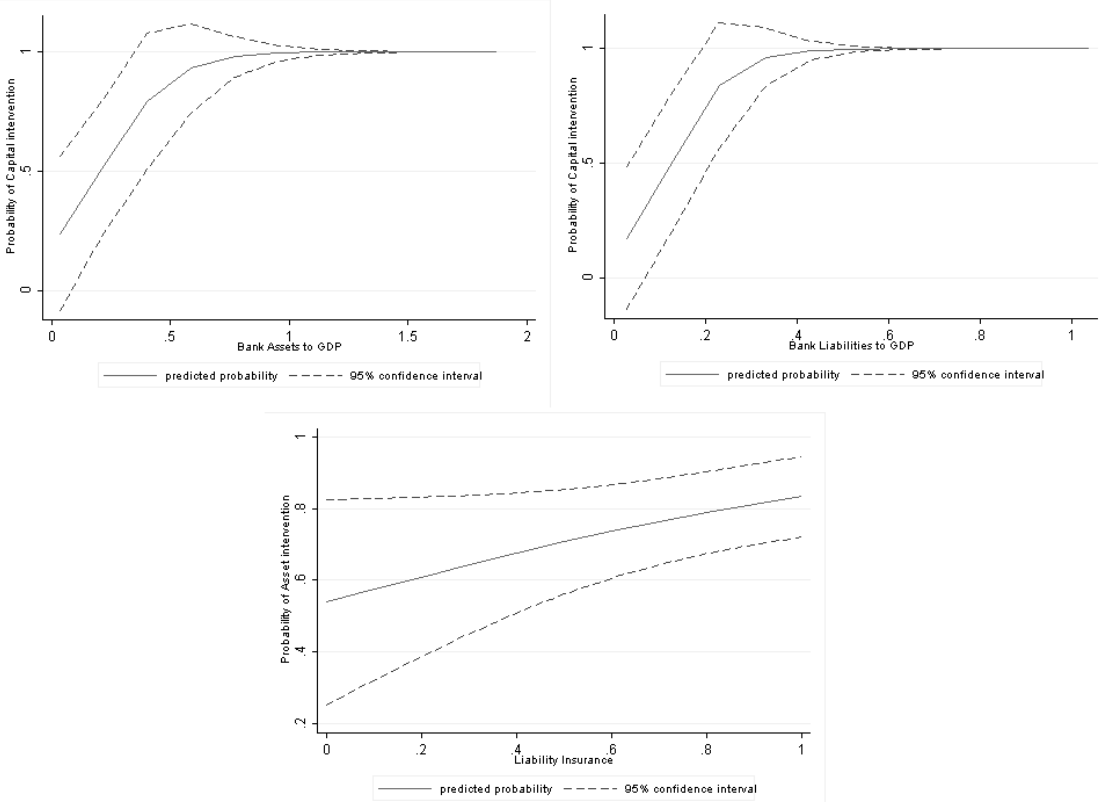

Source: Author's contribution

\subsubsection{Step 2: Unconditional and conditional probabilities of} two interventions

In this part we estimate the probabilities of a governmental decision that incorporates two different types of interventions. Firstly, we calculate simple unconditional probabilities of implementing two types of interventions and also the conditional probabilities of implementing one intervention, given another intervention. Secondly, utilizing logit regressions (two regressions with one explanatory variable each time), we calculate and plot the conditional probabilities of one intervention given another intervention. ${ }^{116}$

116 We use three continuous explanatory variables that represent each intervention group separately: Asset interventions are measured by the 
In this way, we are able to investigate what makes a government more likely to opt for a specific intervention, given that it has already decided on another.

Table 6.5 shows the unconditional and conditional probabilities of a mix of two interventions. 10 out of the 21 countries (probability: 47,6\%) combined a) asset and liabilities management and b) liabilities and equity management interventions, while $42,8 \%$ of the countries ( 9 out of 21) realized concurrently asset and equity side management.

Table 6.5: Unconditional and conditional probabilities for two interventions

\begin{tabular}{|c|c|c|}
\hline Interventions & Observations & $\begin{array}{c}\text { Unconditional } \\
\text { Probability }\end{array}$ \\
\hline Asset and Liabilities management & 10 & 0,476 \\
\hline Asset and Equity management & 9 & 0,429 \\
\hline Liabilities and Equity management & 10 & 0,476 \\
\hline Interventions & Observations & $\begin{array}{c}\text { Conditional } \\
\text { Probability }\end{array}$ \\
\hline Asset conditional on Liabilities & 10 & 0,714 \\
\hline Asset conditional on Equity & 9 & 0,75 \\
\hline Liabilities conditional on Asset & 10 & 0,833 \\
\hline Liabilities conditional on Equity & 10 & 0,833 \\
\hline Equity conditional on Asset & 9 & 0,75 \\
\hline Equity conditional on Liabilities & 10 & 0,714 \\
\hline
\end{tabular}

Even more interestingly, should a government intervenes through one group of interventions, there is at least a $71 \%$ probability that they impose another group of interventions. More specifically, given that a government chooses liabilities interventions, there is a $71,4 \%$ chance that they will also choose either asset or equity management. Moreover, if a government has already intervened through asset management, there is an $83,3 \%$ chance to realize liabilities management and a $75 \%$ chance to realize equity management. Finally, conditional on equity management, governments implement asset interventions at a $75 \%$

total amounts of asset purchases, liabilities interventions by guarantee commitments and equity interventions by capital injections. 
probability and liabilities interventions at an $83,3 \%$ probability.

The logit regression results with the continuous control variables that represent each intervention with the respective coefficients are shown in table 6.6 and are plotted in figure 6.4. ${ }^{117} \mathrm{We}$ find only one significant variable, the guarantee commitments with the equity interventions regression. Even such, for the other five logit regressions, the graphs reveal important findings about the relationship between the variables and the tendency of the respective coefficients.

Table 6.6: Logit regression results for a mix of two interventions conditional variables for asset interventions (A) (two regressions with one explanatory variable each)

\begin{tabular}{|c|c|}
\hline \multicolumn{1}{|c|}{ guarantees } & Coefficient \\
\hline capital injections & 0,077 \\
\hline \multicolumn{2}{|c|}{ conditional variables for liabilities interventions (L) } \\
(two regressions with one explanatory variable each)
\end{tabular}

Concerning asset management, we observe that the relationship is positive and similar for both control variables. Even with very low levels of guarantees and capital injections there is a notable probability (a bit less than 50\%) that governments will implement asset interventions. The confidence margins appear to be narrower at around 10\% of GDP for guarantees and 1\% of GDP for capital injections, revealing greater significance of a probability of around $70 \%$ for these levels.

117 Standard errors and confidence intervals for two interventions are included in table 2 of appendix 6-D. 
Figure 6.4: Probabilities and confidence intervals for a mix of two interventions (explanatory variables measured continuously)
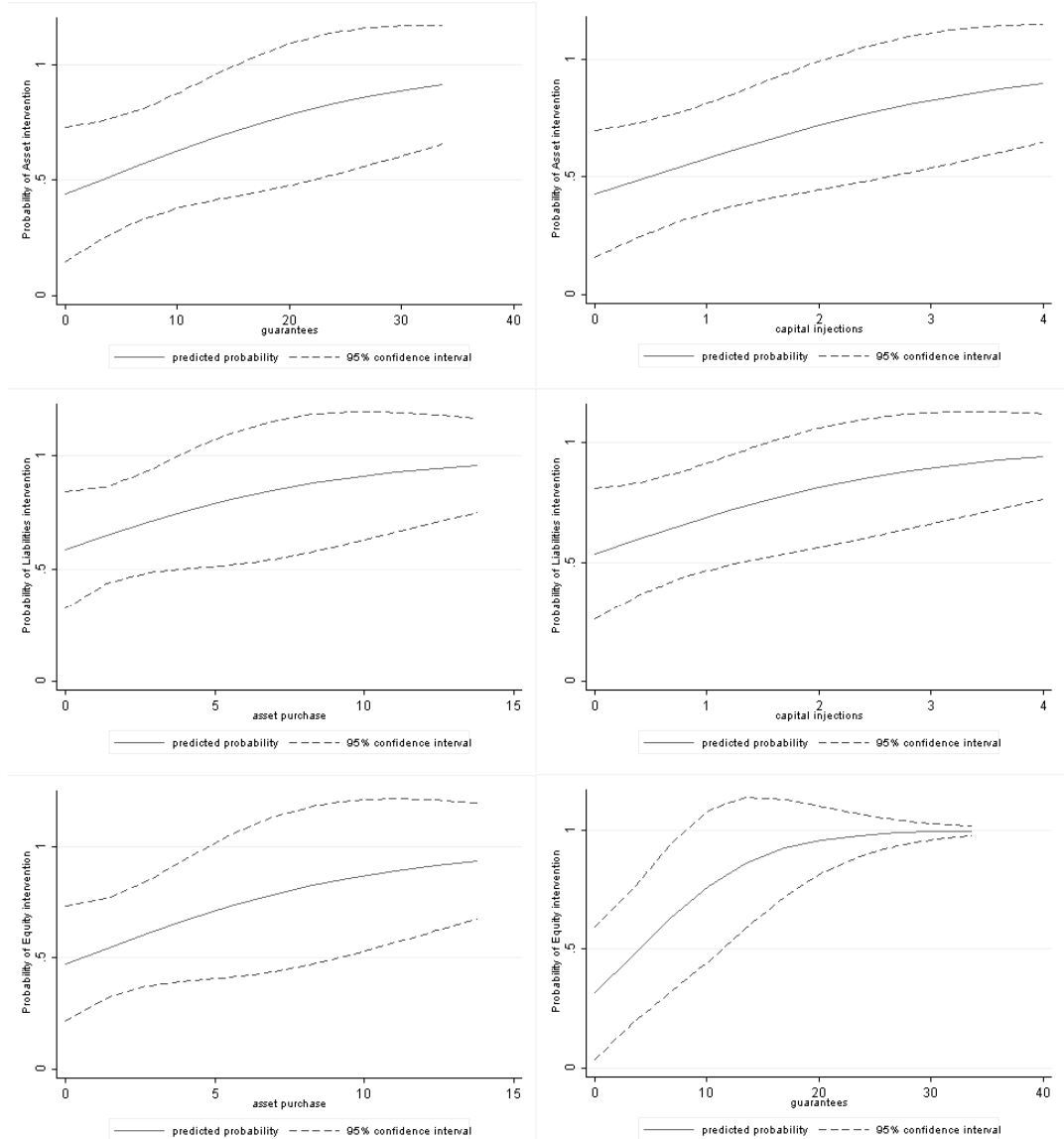

Source: Author's contribution.

For the liabilities regressions, even if both relationships with the relevant probability are positive, the interpretation is slightly different for the two explanatory variables. Regarding asset purchases, there is greater certainty for levels at around $2 \%$ of GDP with the respective probability close to $60 \%$. On the other side, the confidence margins are not that different through varying values of capital injections. We also see that, even for very low levels of both control 
variables, there is a sizeable probability (above 50\%) that governments realize liabilities interventions.

Finally, if we follow the relationship between equity intervention probabilities and asset purchases (which capture asset interventions) and guarantees (which capture liabilities interventions), we find different results. The probability of this specific intervention (around 60\%) is found to be statistically significant only for low levels of asset purchases (around 2\% of GDP). This is similar to the findings of the regression between liabilities intervention and asset purchases. At the same time, we observe a convergence of the confidence interval margins for the regression of equity interventions conditional on guarantee commitments for greater levels of these guarantees. It is almost certain that governments will implement equity side management, if guarantees of above $20 \%$ of GDP are already committed.

\subsubsection{Step 3: Unconditional and conditional probabilities of three interventions}

8 of the 21 countries (around 38\%) have decided to implement measures from all three groups of interventions. The probability of intervening with an additional measure, if governments have already realized two other measures is very high, in any case higher than $80 \%$. More specifically, $90 \%$ of the countries, which apply asset and equity side management also apply liabilities management. If countries intervene through liabilities and equity management or liabilities and asset management, then there is an $80 \%$ chance that they will implement the third measure as well. The results of the unconditional and conditional probabilities for three types of interventions are shown in table 6.7. 
Table 6.7: Unconditional and conditional probabilities for three interventions

\begin{tabular}{|c|c|c|}
\hline Interventions & Observations & $\begin{array}{c}\text { Unconditional } \\
\text { Probability }\end{array}$ \\
\hline $\begin{array}{c}\text { Asset, Liabilities and Equity } \\
\text { management }\end{array}$ & 8 & 0,381 \\
\hline Interventions & Observations & $\begin{array}{c}\text { Conditional } \\
\text { Probability }\end{array}$ \\
\hline Asset given Liabilities and Equity & 10 & 0,8 \\
\hline Liabilities given Asset and Equity & 9 & 0,889 \\
\hline Equity given Asset and Liabilities & 10 & 0,8 \\
\hline
\end{tabular}

At this stage we also perform logit regressions to see the effect on each group of measures, given the two other interventions. Thus, we run one regression per group. More precisely, there is one regression with asset management (dummy variable) as the dependent variable and two continuous explanatory variables, which measure liabilities management (guarantees) and equity management (capital injections). Secondly, the liability side regression includes asset purchases and capital injections measuring asset and equity management and the dummy variable for liability management as the dependent variable. Likewise, we regress the dummy equity variable to asset purchases and guarantees measuring asset and liabilities management continuously. ${ }^{118}$

Table 6.8 shows the results with the respective coefficients for the three different regressions. ${ }^{119}$ We notice that all the variables have positive coefficients except for the asset purchase variable in the equity management regression. However, we only find one significant variable (at the $95 \%$ confidence level); that is guarantees in the equity intervention regression.

\footnotetext{
${ }^{118}$ The effect of the explanatory variables that we capture concerns average values of these variables. We can also run logit regressions that capture the effect of the explanatory variables on the maximum and the minimum values.

119 Standard errors and confidence intervals for three interventions are included in table 3 of appendix 6-D.
} 
Table 6.8: Logit regression results for a mix of three interventions conditional variables for asset intervention (A) (one regression with two explanatory variables)

\begin{tabular}{|c|c|}
\hline & Coefficient \\
\hline guarantees & 0,024 \\
\hline capital injections & 0,56 \\
\hline \multicolumn{2}{|c|}{$\begin{array}{l}\text { conditional variables for liabilities intervention (L) } \\
\text { (one regression with two explanatory variables) }\end{array}$} \\
\hline & Coefficient \\
\hline asset purchases & 0,107 \\
\hline capital injections & 0,581 \\
\hline \multicolumn{2}{|c|}{$\begin{array}{l}\text { conditional variables for equity intervention }(\mathrm{E}) \\
\text { (one regression with two explanatory variables) }\end{array}$} \\
\hline & Coefficient \\
\hline asset purchases & $-0,118$ \\
\hline guarantees & $0,242 *$ \\
\hline
\end{tabular}

In figure 6.5 we plot guarantees and capital injections for the asset management regression. For guarantees, we observe that confidence intervals are close for values near $10 \%$ of GDP with a probability at around $60 \%$. For the same probability, the confidence margins are quite narrow at around $1 \%$ of capital injections on GDP. For the liabilities management regression, we note similar results for both explanatory variables. The probabilities (around 70\%) seem more significant in terms of confidence intervals at $0,3 \%$ of GDP for asset purchases and at a bit more than 1\% of GDP for capital injections.

Finally, we have different findings for the explanatory variables in the equity regression. The negative relationship between the probability of equity interventions and the asset management is a very interesting result. It contradicts with our findings in the previous part, where we find that the relationship between the two was positive. Inserting guarantees into the equation, changes the direction of the relationship for asset purchases. It is less likely to intervene through equity management if a government commits more funds through asset purchases, given that they have already intervened with asset purchases and guarantees. The result is more robust for values of asset purchases at around 0,4\% of GDP with a respective probability at $70 \%$. On the contrary, 
the results for guarantees are similar to step 2. We indicate a positive relationship between the probability of equity interventions and guarantee commitments with the confidence intervals converging at very high guarantee levels. Thus, as already emphasized before, with extensive guarantees, it almost certain that governments will combine concurrently equity management. This time though, the conditionality includes asset purchases as well.

Figure 6.5: Probabilities and confidence intervals for a mix of three interventions (explanatory variables measured continuously)
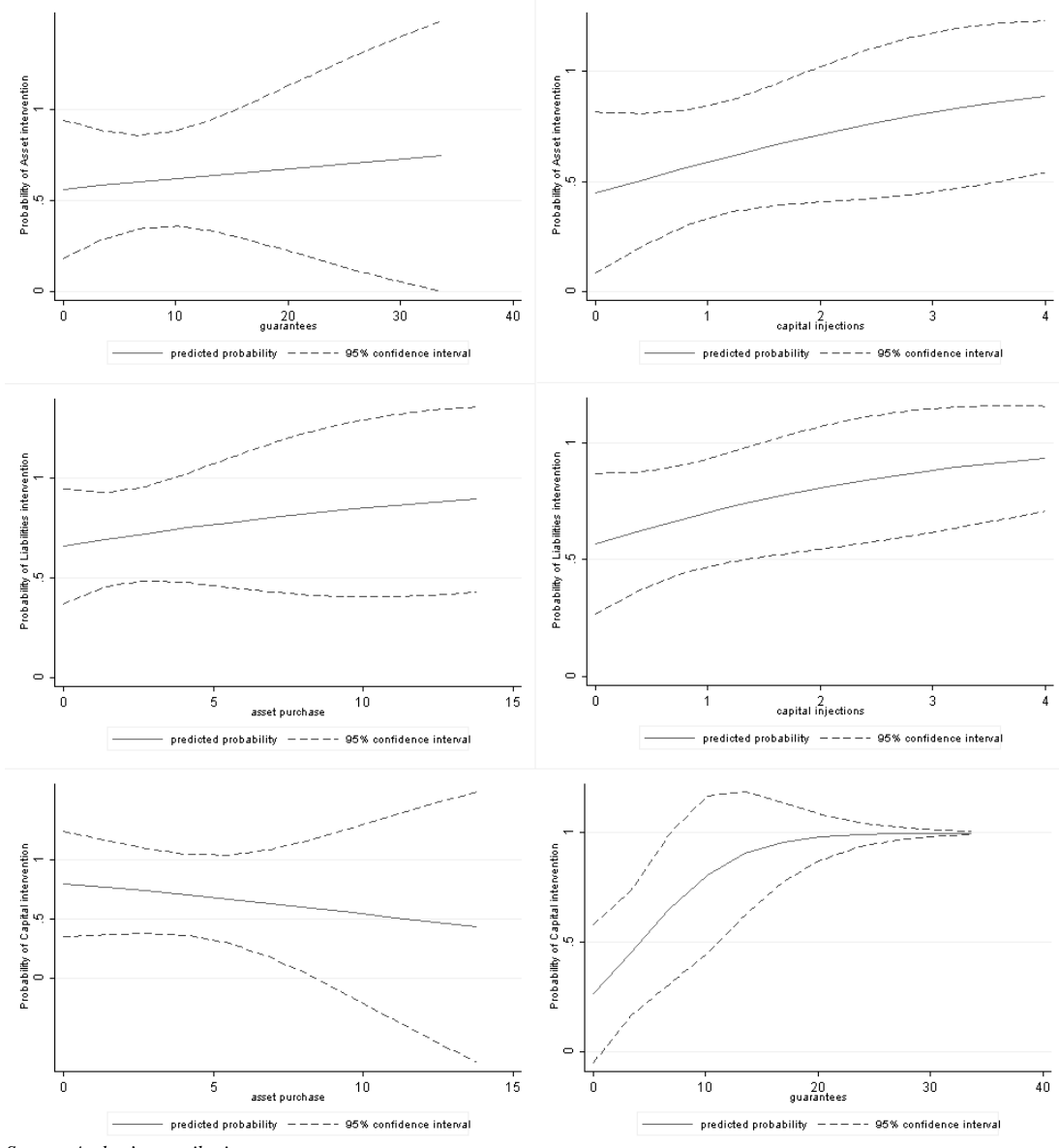

Source: Author's contribution. 


\subsection{Concluding remarks}

We summarize the main findings of the chapter in figure 6.6.

Figure 6.6: Summary of results for government intervention decisions

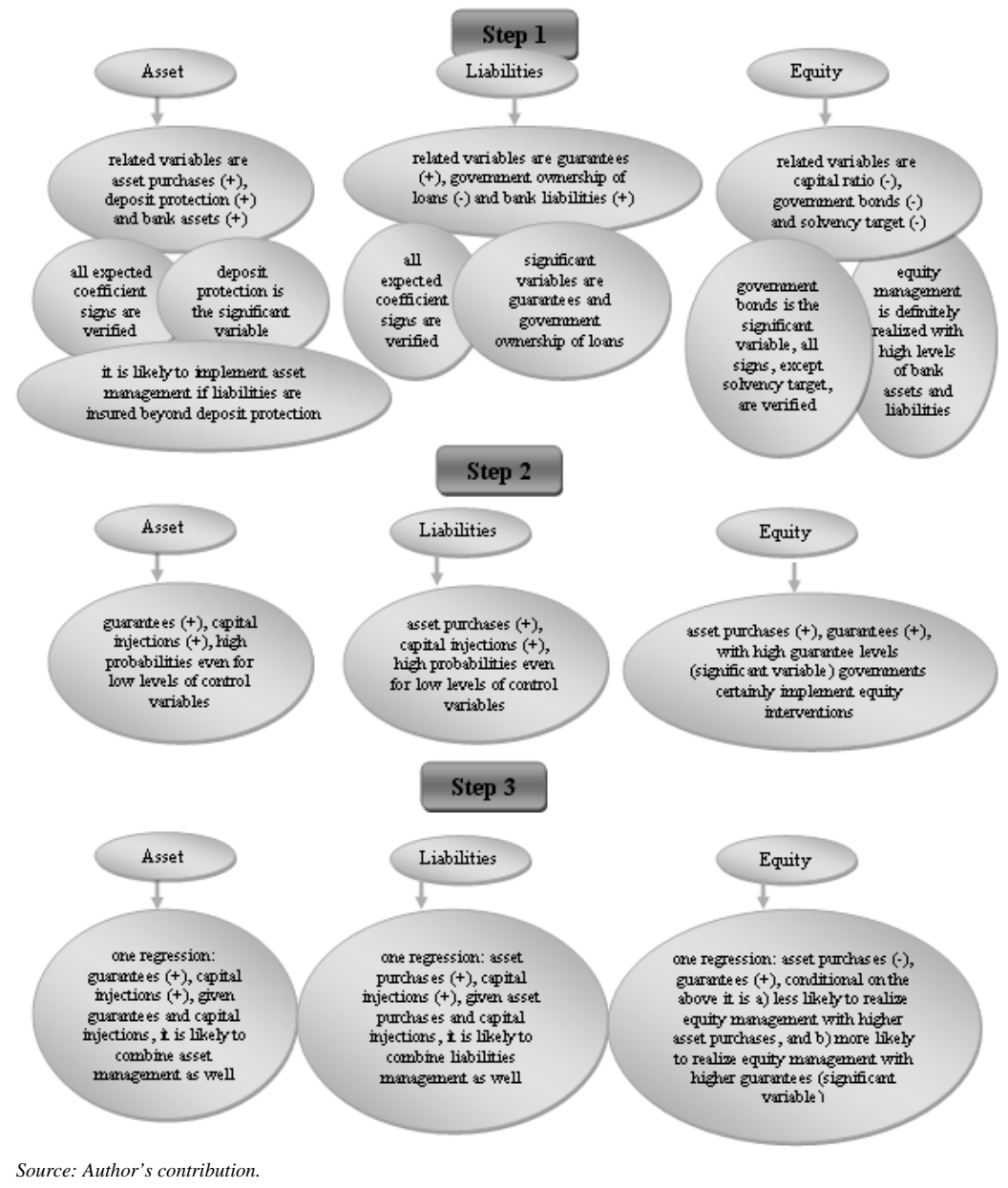

Generally, we observe that the probability to implement additional interventions, given that a government has already imposed measures from other groups, is very high (in all cases more that 70\%). For liabilities intervention, conditional on asset purchases or equity injections or both, this likelihood is a bit higher. This is our first significant policy implication. 
Liabilities management such as deposit and other debt guarantees were not only the most commonly used intervention, but also an auxiliary measure that was applied in almost all cases concurrently with asset and equity interventions.

As far as asset management is concerned, the existence of deposit protection scheme and any liability insurance beyond that, is expected to increase the log odds for asset interventions. Furthermore, policymakers typically utilize asset side policies, if they have already intervened through liabilities or equity management or both. As these committed funds increase, the probability of asset management increases as well.

Increased guarantee levels are reasonably expected to increase the probability of liabilities intervention, while considerable public ownership of bank loans does not give much space for extending liabilities management. This reveals that extensive bank asset public ownership may drive governments to implement mainly asset interventions and does not give flexibility for other measures. Moreover, if government loan ownership is sizeable, then there is no need for additional guarantees, because most of the loans are already "collateralized" through public ownership.

The significant variable that is linked with equity interventions is the portion of government securities on bank assets. This proves that a banking system that is heavily depended upon government securities impels governments to achieve limited and targeted results, mainly concerning asset side policies. Furthermore, extended exposures that are revealed with sizeable assets and liabilities of the banking system require immediate resolution measures, giving space for equity side management. Lastly, we find that policymakers definitely choose equity side management if guarantee commitments are very high. We can thus deduce that guarantees are a very important determinant for the decision of the government to implement equity interventions. 


\section{Conclusion}

\subsection{Using private methods to assess public project risk in PPPs}

The first main research question, as set in the introduction deals with the conditions that governments should consider when engaging in alternative types of PPPs, in order to minimize the negative PPP effects on national debt and the impact of government PPP guarantees. This question is addressed in chapters two and three, where we assess the impacts of direct cash flows and contingent liabilities that arise from PPP contracts, on the fiscal profile of a country.

In chapter two, we define PPPs as "contractual agreements for a shift of the supply of a good or a service, or the construction of an infrastructure asset, from the government to the private sector, where efficient risk allocation among the partners and transparent recording of all government future and contingent obligations are of utmost importance." We also argue that there are decisive features in PPP contracts, which may contribute to incomplete contracting: the contingent public-side liabilities, the risk allocation (which increases transaction costs), the hybrid entrepreneurial scheme and the long-term lifespan of the PPP.

The purpose of the study in chapter three is to propose a method that can be adapted to any country's PPP program and evaluate the effect that the PPP risk imposes on the national accounts. The contribution of the chapter has two aspects. We introduce a novel finance technique to value the PPP risk and we present the various inflows and outflows that are realized with each different scenario. Having determined a value for the sum of the contingent net cash flows, we also see their effect on an investor's perspective. Thus, the contingent effect is practically assessed on a financial viewpoint. As discussed, the guarantees for our unit of analysis resulted in negative net cash flows, which increase the probability of default (extending the debt position) of a said country.

More precisely, the four scenarios are described as follows. The first scenario presents the case where all PPP 
projects are supposed to be financed by the government as typical public investment. There is a direct effect on the present capital account of the government, since the initial investment cost of the project is included in the country's deficit/surplus. This effect can be counterbalanced by positive flows from user fees. In the PPP scenario, we introduce the fiscal effect of the net contingent flows for the government, as the difference between expected revenues and guarantees, should the latter be called. This attribute has a financial viewpoint as well. An investor who is interested in investing in a country's government bonds should not only consider a narrow definition of debt, but also include these net contingent flows as a portion of the overall debt position of the country. In the third and in the fourth scenario, we assume that the government can reduce its risk exposure from the guarantee, by buying protection against the probability of the private partner's default via a credit default swap (CDS). Except from the typical cash flows of the PPP scenario, there is a payment towards the issuer of the CDS and a reverse contingent CDS payoff towards the public partner, if the private partner defaults. We calculate the mid-market CDS spread with (fourth scenario) and without (third scenario) considering the government's probability of default. In this way, we evaluate the price of the public risk exposure in a PPP.

\subsection{The ex ante determinants and the ex post effects of government crisis interventions}

The recent financial turmoil of 2007 triggered a systemic risk crisis with serious liquidity and solvency considerations. There were specific responses from governments to deal with the deterioration of the financial system, in order to provide consistent remedies. The second research question of the thesis is set to analyse different aspects of these policy actions: "Realizing PPPs as a policy tool in a banking crisis incident, what are: a) the effects of these partnerships on sectoral balance sheets, b) the basic determinants of the governmental decisions to intervene during and after the crisis and c) the most efficient 
interventions in terms of total public exposure and neutrality?" Addressing the above, we find that guarantees impose a direct effect to national accounts, in the sense that they constitute explicit contingent obligations. These contingencies potentially affect debt sustainability and fiscal solvency.

In chapter four, we introduce a balance sheet approach for categorizing and assessing the effects of these crisis remedies. We distinguish between asset management, liabilities management and equity management interventions. The first group consists of purchases of distressed assets, ringfencing and loan loss provisions. Liabilities management includes deposit insurance protection and other debt guarantees on principal, interest and interbank liabilities. Equity side interventions incorporate recapitalization, direct equity injections, mergers and (partial) nationalization.

The balance sheet results after the government interventions are assessed in chapter five. The prime concern about asset management is the proper valuation of the true value of the assets. The factor that is difficult to capture is the macroeconomic shock. Thus, the government could increase its risk exposure, since it may accept assets on-balance, which cannot be properly evaluated. On the bank's balance sheet, there is a rearrangement of the asset structure of the bank, increasing the banking system's liquid and "healthy" assets. The main capital to asset ratio and the return on equity ratio remain unchanged. By definition, guarantees constitute offbalance sheet items and do not affect sectoral conventional balance sheets. We thus argue that they are the most neutral intervention. However, by analysing an extended balance sheet, we are able to capture the guarantee effect, considering it as an alternative bank asset and an explicit (contingent) liability for the government. The extended balance sheet totals increase, the bank performance is undervalued and the capital requirement is overvalued. Equity interventions results in increased balance sheet totals for the banking system, by the exact amount of the capital that was injected. The public sector's balance sheet totals remain unaltered. There is a notable undervaluation of performance ratios and a significant 
overvaluation of capital adequacy. Undoubtedly, equity side management incorporates the most influential measures. This is also observed when combining asset and equity interventions. In that case, the dominant intervention concerns the direct equity injections compared to asset purchases. These findings direct us to three significant arguments. Asset interventions, because of their neutrality, can be combined with more influential measures, since they leave significant balance sheet elements unaffected. Secondly, with a combination of asset and equity interventions, policymakers focus on liquidity provision, and do not address solvency and deleverage targets. Finally, the influence of each crisis measure heavily depends on the effect on the banking system's equity position.

In chapter six, we introduce an approach to illuminate the decision process of the governments, to either intervene or do nothing in case of a crisis and - should they decide to intervene - to choose among different interventions. This estimation process constitutes three steps. The findings are summarized as follows. Firstly, the existence of a deposit protection system and any additional insurance of liabilities are both significant for the government's decision on asset management. Moreover, governments usually implement asset management if they have already decided to intervene through the other two groups of interventions. Secondly, with substantial guarantee commitments, it is almost certain that governments realize liability-side interventions. On the contrary, considerable public ownership of bank loans does not give much space for extending liabilities management. This is because, a) extensive bank asset public ownership drive governments to implement mainly asset interventions and b) there is no need for additional guarantee commitments, since most of the loans are already "collateralized" through public ownership. Thirdly, we find that an increase in the portion of government securities on bank assets reduces the probability of equity interventions. Moreover, extended exposures of the banking system (in terms of bank liabilities) and numerous open positions of financial institutions (as 
depicted by sizeable bank assets), both require immediate action through equity interventions.

\subsection{Public commitments and policy lessons}

As portrayed in the above sections, this study discusses off-balance sheet exposures of sectoral accounts in depth. These are realized in plain PPP projects, but also in government interventions through the banking system to restore the banking crisis, which constitute a different type of PPP. There are two antitheses for the assessment of the effect of such contingencies.

Firstly, policymakers must consider that the potential public-side obligations, which lead to opportunism of the individual parties and are difficult to consider, is a feature that may attribute to incomplete contracting. These commitments constitute by definition future liabilities for the government should a specific event occur. Governments typically do not concentrate on the risk that sources from them when assessing their overall risk profile. However, pricing of this risk is very important in terms of the proper valuation of the public debt because there is a significant influence on debt dynamics. If governments do not consider the risk that originates from contingent commitments, then (new) government debt may not be appropriately assessed. In a complex national accounting content, the accurate valuation of any public commitment is imperative, both from a financial and a macroeconomic perspective.

We propose a method that officials can use to price this risk. The first step is to calculate the net contingent flows and to include them in the debt position of the country. Further on, we suggest CDS valuation. The mid market CDS spread (with the total amount of the commitments as the notional principal) can be obtained by calculating the expected CDS payments and payoffs. This methodology can be used to incorporate government (counterparty) default as well. In this way, policymakers are able to capture all negative contingent cash flows that government commitments may cause. Taking a financial viewpoint, they can also view a guarantee as an 
option. The government has a short position in a put option and they are better off as long as the total assets are greater that the debt plus these net contingent flows.

Apart from the guarantee effect, there is a policy implication that is derived from our results on PPP cash flows. The private partner in a PPP is accountable for the start-up capital expenditure of the project. Therefore, there is a reduction in the current public capital expenditure. Since, in this way, PPPs seem to improve the primary balance, they may be used from governments as a tool to circumvent budgetary controls and to move public investment off-budget. However, the present capital expenditure is transformed into future current expenditure, spread over the forthcoming periods. To put it bluntly, present negative public cash flows are transferred to the future.

Summing up, the accounting viewpoint of PPP contingencies (and the relevant risk) and the cash flow analysis address an interesting policy lesson. PPPs are very close to a typical public investment from a government's perspective. This is because, a) explicit contingent obligations that arise from PPPs are similar to sovereign debt commitments that result from public borrowing, and b) project costs in terms of construction and operation or other cash outflows will - at some point in the future - burden the taxpayers. ${ }^{120}$

Secondly, there also exists a positive viewpoint of public guarantees. PPP guarantees are similar to government guarantees as crisis remedies. They can both be considered as direct credit subsidies with equivalent public exposure. To this respect, governments have efficiently used guarantees in various formats. Deposit insurance protection and debt guarantees on principal and interest (liabilities management) served in deleveraging insolvent institutions. Apart from that government guarantees appear as a shield for future asset losses (asset management). Moreover, guarantees are very

${ }^{120}$ We, thus, fortify the Engel et al. (2008) findings who, using an optimal risk sharing contract approach, conclude that PPPs are closer to typical public procurement than temporary privatization. 
influential in the decision process of the government to realize equity interventions. Policymakers suitably combine equity management with sizeable guarantee commitments. It would not be efficient to remove distressed bank assets or to inject funds to the banking system without guaranteeing either deposits or future losses from these assets. Thus, we accentuate the positive side of public guarantees during crisis periods. Even if there are specific limitations (for example, we find that for sizeable government loan ownership, there is no need for additional guarantee commitments), guarantees are the best tool to restore market actors' trust, while maximum public exposures are well known. They are the most neutral intervention since they constitute by definition an off-balance sheet item, and do not affect the conventional balance sheet. Guarantees persistently seem like an essential measure for banking crisis management.

We also derive other important policy implications from the analysis of the effects and the determinants of government interventions. Disclosed guarantees, as aforementioned, are the most neutral and quantifiable interventions. The most influential intervention is the equity management, while asset management falls between the two. Government officials must consider that, realizing the latter two, it is difficult to evaluate the proper asset price because of the macroeconomic shocks. So, when they decide to increase bank's equity through public funds and to enhance liquidity through assets purchases they have to: a) transparently define bank solvency and b) properly evaluate bank assets that determine, not only their own value, but also the value of the bank as a firm. In any case, asset purchases and direct equity injections that were implemented by governments as sole measures are not proved sufficient on their own. They also have to be accompanied by guarantees, in order to provide a holistic resolution.

Even such there are specific aspects of liabilities interventions that require the focused attention of policymakers. Since guarantees incorporate by definition offbalance sheet items, they have to be appropriately disclosed 
within a fiscally sustainable context. Therefore, a novel regulatory framework must incorporate transparent consolidated rules, granular supervision of off-balance sheet activities, and better management of the counterparty risk in the relevant transactions. It is imperative that prudential regulation foresees incentives for capital buffering, mainly in the form of collateral, in the post-crisis period. The caveats though for the government are much greater in the cases of asset and equity management.

Policymakers rightfully consider that it would not be efficient to guarantee deposits or to inject funds into the banking system (through nationalization or subordinated debt) and leave "bad" bank assets on-balance. Given that governments commit guarantees and direct equity funds (or both) to restore the banking sector, they should proceed to asset purchases as well, in order to heal the distressed asset side of the banking system balance sheet. However, officials must be aware of the possibility that distressed asset purchases can bring the government in the underdog position and can increase moral hazard and public risk exposure. The difficulty in the valuation of these assets is also addressed in this study.

We identify the positive effects of the decision of many governments to accompany direct capital injections with sizeable guarantee commitments. We find that guarantees are very influential in the decision process of the government to apply equity interventions. ${ }^{121}$ However, there are precise concerns that must be tackled when implementing equity management. Even if governments directly injected sizeable funds towards the banking system, they failed to recognize many negative externalities. These have to do with insolvency due to higher leverage, increased risky assets and potentially bending the rules of competition. Policymakers did not

121 We extend findings from previous literature (La Porta et. al. 2000, Honohan and Klingebiel 2003, Hoshi and Kashyap 2009, Montgomery 2005) that with capital injections, governments are more likely to implement an extended combination of measures with additional asset and liability side policies. We additionally find that policymakers prefer to implement equity management with guarantees, especially if they incorporate a wider mix of interventions that capture all three groups. 
consider other drawbacks as well, which were revealed through the ex post analysis. Initially, recapitalization measures overvalue the core capital ratio, since they have a direct effect on the capital requirement. Furthermore, a banking system that is heavily dependent on government securities does not favour equity interventions. Policy makers in this case can only achieve limited and targeted results, mainly concerning asset side policies, and are not flexible to extend other measures. To sum up, equity management constitutes the most direct and influential interventions such as direct capital injections and (partial) nationalization. Even if this seems to be an instant answer for the short-term recovery of the banking system, it must be cautiously assessed since it could bend significant indicators of the banking system.

In conclusion, a proper rescue plan should address the following features: a) be focused on specific targets, b) ensure that the measures for realizing these targets are not counteractive, c) minimize principal-agent conflicts and moral hazard consequences and d) be centered around solvent financial institutions. Its success is directly linked with collaboration on an international level, in order to stabilize the banking system, to avoid financial market's distortions and to manage systemic risk. We observe throughout our research, that with any intervention and any public commitment created (contingent or not), disclosure, transparency and monitoring are imperative elements of such policy (re)actions. In order to deal with its role as a "de facto guarantor," the government must monitor all distorted financial bank assets, hedge the guaranteed liabilities, prevent excessive risk-taking and link the guarantee premium that it charges on the risk exposure that it bears.

To this effect, we agree and fortify the Dewatripont and Tirole's (1993) claim on deregulation. It is time to sit back and think about significantly decreasing deregulation in the banking system. Reregulation can be accompanied by containment measures, such as explicit deposit protection schemes and barriers on highly leveraged positions. Even though - in crises periods - the temptations for forbearance in 
terms of regulatory restrictions are larger compared to tranquil periods, capital requirements on risky balance sheet positions should incorporate incentives for banks to better manage their risk profile. A combination of guarantees schemes in liabilities and asset management, and prudential reregulation, could provide an answer to concerns on banking system restoration. 


\section{Bibliography}

Acharya, S. \& Dreyfus, J., 1989. "Optimal Bank Reorganization Policies and the Pricing of Federal Deposit Insurance," Journal of Finance, 44, pages 1313-1334

African Economic Outlook, 2009. "South Africa Country Statistics," retrieved December 30 2009 from www.africaneconomicoutlook.org

Akitoby, B., Hemming, R. \& Schwarz, G., 2007. "Public Investment and Public-Private Partnerships," International Monetary Fund Economic Issues Series, 40, International Monetary Fund, Washington D.C.

Arrow, K. \& Lind, R., 1970. "Uncertainty and the Evaluation of Public Investment Decisions," American Economic Review, vol. 60, pages 364-378

Avery, R. \& Berger A., 1991. "Loan commitments and bank risk exposure," Journal of Banking and Finance, Elsevier, vol. 15 (1), pages 173-192

Banco Central do Brazil, 2009. "Economic indicators database," Ministry of Finance, retrieved December 30 2009 from www.bcb.gov.br

Bank for International Settlements (BIS), 2009a. "BIS Annual Report 2008 / 2009," June 2009, BIS Publications and Research, retrieved April 3rd 2010 from www.bis.org/publ 2009b. "BIS Quarterly Review, December 2009,” BIS Locational Banking Statistics, retrieved January 30th 2010 from www.bis.org/statistics/bankstats

Bank of Canada, 2009. "The Bank of Canada: Taking action to address the global financial crisis," Ottawa, Ontario

Bank of Greece, 2009. "Financial Stability Report," Directorate of Financial Stability, June 2009, Athens

Barnett, S., Davis, J., Ossowski, R. \& Richardson, T., 2000. "Fiscal and Macroeconomic Impact of Privatization," IMF Occasional Papers 194, International Monetary Fund, Washington D.C. 
Beck, T., Demirgüç-Kunt, A. \& Levine, R., 2000. "A New Database on Financial Development and Structure," World Bank Economic Review 14, pages 597-605, the World Bank, Washington D.C.

Ben-Akiva, M., 1973. "Structure of passenger travel demand models," PhD thesis, Department of Civil Engineering, Massachusetts Institute of Technology

Bendeich, M., 2008. "Australia guarantees bank deposits to combat crisis," Reuters U.S. edition article, retrieved January $2^{\text {nd }} 2010$ from www.reuters.com

Birdsall, N. \& Nellis, J., 2003. "Winners and Losers: Assessing the Distributional Impact of Privatization," World Development, Elsevier, vol. 31(10), pages 1617-1633

Black, F. \& Scholes, M., 1973. "The pricing of options and corporate liabilities," Journal of Political Economy, 81, pages 637-659

Bolton, P. \& Dewatripont, M., 2005. "Contract Theory," MIT Press, Cambridge MA

\& Scharfstein, D., 1996. "Optimal Debt Structure and the Number of Creditors," Journal of Political Economy, 104-1, pages 1-25

Boot, A. \& Thakor, A., 1991. "Off-balance sheet liabilities, deposit insurance and capital regulation," Journal of Banking and Finance, Elsevier, vol. 15(4-5), pages 825-846

Borio, C. \& Nelson, W., 2008. "Monetary operations and the financial turmoil," BIS Quarterly Review, Bank for International Settlements (BIS), pages 31-45

Boyd, J. \& Gertler, M. 1993. "US commercial banking: Trends, cycles and policy," NBER Macroeconomics Annual 1993, Volume 8, pages 319-377, National Bureau of Economic Research, Cambridge MA

Breitenfellner, B. \& Wagner, N., 2009. “Government Interventions in Response to the Subprime Financial Crisis: The Good into the Pot, the Bad into the Crop," Passau University, retrieved April $7^{\text {th }} \quad 2010$ from http://ssrn.com/abstract=1334804

Central Bank of Argentina, 2009. "Macroeconomic Radar," retrieved December $30^{\text {th }} 2009$ from www.bcra.gov.ar 
Central Intelligence Agency (CIA), 2009. "The World Factbook," retrieved December $30^{\text {th }} 2009$ from www.cia.gov/library/publications/the-world-factbook

China Banking Regulatory Commission, 2008. "2007 Annual Report," China Banking Regulatory Commission $(C B R C)$, Beijing

Connolly, K., 2008. "Banking crisis: Germany earmarks €500bn for rescue package," Published by The Guardian UK, retrieved October $20^{\text {th }} 2009$ from www.guardian.co.uk

Corner, D., 2006. "The United Kingdom Private Finance Initiative: The Challenge of Allocating Risk," OECD Journal on Budgeting, 5(3), 37-55

Crouhy, M. \& Galai, D., 1991. "A Contingent Claim Analysis of a Regulated Depository Institution," Journal of Banking and Finance, 15, pages 73-90

Dell'Aricia, G., Detragiache, E. \& Rajan, R., 2008. "The real effect of banking crises," Journal of Financial Intermediation, 17 (2008), pages 89-112

Demirgüç-Kunt, A., Karacaovali, B., \& Laeven, L., 2005. "Deposit Insurance around the World: A Comprehensive Database," World Bank Policy Research Working Paper 3628, the World Bank, Washington D.C.

Dennis, S. \& Mullineaux, D., 2000. "Syndicated Loans," Journal of Financial Intermediation, volume 9, issue 4, pages $404-426$

Department of Finance Canada, 2008. "The Economic and Fiscal Statement 2008," Chapter 2: Responsible Leadership: Actions to Strengthen Canada's Economic and Financial Fundamentals, Ottawa, Ontario

Desjardins Economic Studies, 2008. "The Impact of the Financial Crisis in Canada," abstract retrieved October $20^{\text {th }}$ 2009 from www.desjardins.com

Dewatripont, M. \& Legros, P., 2005. "Public-Private Partnerships: Contract Design and Risk Transfer," European Investment Bank Papers, Volume 10, No. 1, European Investment Bank, Luxembourg 
\& Tirole, J., 1993. "The Prudential

Regulation of Banks," MIT Press, Cambridge MA

Disyatat, P., 2009: "Unconventional monetary policy in the current crisis," BIS Quarterly Review, Bank for International Settlements (BIS), pages 6-7

Engel, E., Fisher, R., \& Galetovic, A., 2008. "The Basic Public Finance of Public-Private Partnerships," Cowles Foundation Discussion Paper No. 1618, Yale University, New Haven, Connecticut

European Central Bank, 2010. "Euro Area Fiscal Policies and the Crisis," European Central Bank (ECB) Occassional Paper No. 109, April 2010, Frankfurt 2009. "Guiding Principles for

Bank Assets Support Schemes," European Central Bank $(E C B)$, Frankfurt

European Investment Bank (EIB), 2004. "The EIB's Role in Public-Private Partnerships (PPPs)," European Investment Bank (EIB), Luxembourg

Eurostat, 2004. "Treatment of Public-Private Partnerships," News Release No. 18, Brussels

Federal Ministry of Finance, Fiscal and Economic Policy, 2008. "German Stability Programme," December 2008 update, Berlin

Fourie, F., \& Burger, P., 2001. "Fiscal Implications of Public-Private Partnerships (PPPs)," South African Journal of Economics, vol. 69:1, pages 147-168

2000. "An Economic Analysis and Assessment of Public-Private Partnerships (PPPs)," South African Journal of Economics, vol. 68, pages 693-725

Gomez-Lobo, A. \& Hinojosa, S., 2000. "Broad Roads in a Thin Country," World Bank Policy Research Working Paper, No. 2279, the World Bank, Washington D.C.

Gorton, G., 2007. "The Panic of 2007," Yale School of Management and National Bureau of Economic Research (NBER), New Haven, Connecticut 
Greek Government Gazette, 2008. "Law 3723 / 2008," Registry Number 250, 9-12-2008, Ministry of Economics and Finance, Republic of Greece, Athens

Greene, W., 1990. "Econometric Analysis," 6 ${ }^{\text {th }}$ edition, Chapter 23: Models for Discrete Choice, New Jersey: Prentice Hall

Haldane, A., Hoggarth, G., Saporta, V. \& Sinclair, P., 2004. "Financial Stability and Bank Solvency," Chapter 5 from the book "Systemic Financial Crises. Resolving Large Bank Insolvencies," editors: Evanoff, D., \& Kaufman, G., World Scientific Publishing (2005), London

Hart, O., 2002. "Incomplete Contracts and Public Ownership: Remarks and an Application to Public-Private Partnerships," CMPO Working Paper Series, No. 03/061, Harvard University

Hemming, R., 2006. "Public-Private Partnerships, Government Guarantees and Fiscal Risk," International Monetary Fund, Fiscal Affairs Department, International Monetary Fund, Washington D.C.

HM Treasury, 2000. "Public-Private Partnerships. The Government's Approach,” Her Majesty's Stationery Office, HM Treasury, London

Honohan, P. \& Klingebiel, D., 2003. "The fiscal cost implications of an accommodating approach to banking crises," Journal of Banking and Finance, 27 (2003), pages $1539-1560$

Hoshi, T. \& Kashyap, A., 2009. "Will the U.S. Bank Recapitalization Succeed? Eight Lessons from Japan," Chicago Booth Research Paper No. 09-28, Chicago

House of Commons, Treasury Committee, 2009. "Banking Crisis: dealing with the failure of the UK banks," Seventh Report of Session 2008-09, London

Hull, J., 2006. "Options, futures, and other derivatives," $6^{\text {th }}$ edition, Chapter 27: Credit Derivatives, New Jersey: Prentice Hall 
International Monetary Fund, 2010. "A Fair and Substantial Contribution by the Financial Sector," Interim Report for the G20, Meeting of the G20 Ministers, April 2010, International Monetary Fund, Washington D.C.

2009a. "Global

Financial Stability Report - GFSR," World Economic and Financial Surveys, International Monetary Fund, Washington D.C.

2009b. "Initial Lessons of the Crisis," IMF Policy Paper, International Monetary Fund, Washington D.C.

2009c. "Lessons of the

Financial Crisis for Future Regulation of Financial Institutions and Markets and for Liquidity Management," IMF Policy Paper, International Monetary Fund, Washington D.C. , 2009d. "Stocktaking of the G20 Responses to the Global Banking Crises," Note by the staff of the International Monetary Fund, International Monetary Fund, Washington D.C.

2009e. "The State of

Public Finances: Outlook and Medium-Term Policies After the 2008 Crisis," Companion Paper, Seminar of the Executive Board of the International Monetary Fund, $20^{\text {th }}$ February 2009, International Monetary Fund, Washington D.C.

2009f. "World

Economic Outlook Report," World Economic Outlook (WEO) Database, April 2009, International Monetary Fund, Washington D.C.

2009g. "Global

Economic Policies and Prospects," Meeting of the Ministers and Central Bank Governors, March 13-14, 2009, London, U.K., Note by the staff of the International Monetary Fund, International Monetary Fund, Washington D.C. ,2009h. "The State of Public Finances: Outlook and Medium-Term Policies after the 2008 Crisis," IMF Fiscal Affairs Department, International Monetary Fund, Washington D.C. 
2007. "Manual on

Fiscal Transparency 2007," International Monetary Fund, Washington D.C.

2005a. "Government

Guarantees and Fiscal Risk," International Monetary Fund, Fiscal Affairs Department, International Monetary Fund, Washington D.C.

2005b. "Public

Investment and Fiscal Policy - Lessons from the Pilot Country Studies," International Monetary Fund, Fiscal Affairs Department, International Monetary Fund, Washington D.C.

2005c. "Public

Investment and Fiscal Policy - Summaries of the Pilot Country Studies," International Monetary Fund, Fiscal Affairs Department, International Monetary Fund, Washington D.C. 2004a. "Public Investment and Fiscal Policy," International Monetary Fund, Fiscal Affairs Department, Policy Development and Review Department, International Monetary Fund, Washington D.C. 2004b. "Public-Private

Partnerships," International Monetary Fund, Fiscal Affairs Department, International Monetary Fund, Washington D.C. 2003. "External Debt

Statistics. Guide for Compilers and Users," International Monetary Fund, Washington D.C. 2001. "A Manual on

Government Finance Statistics," International Monetary Fund, Washington D.C.

Jiabao, W., 2009. "Premier's Wen Jiabao press conference," press conference after the closing meeting, March 13, 2009, Second Session of the 11th National People's Congress (NPC), Beijing

Jones, E. \& Mason, S., 1980. "Valuation of Loan Guarantees," Journal of Banking and Finance, 4, pages 89107

Keyes, B., Mukherjee, T., Seru, A. \& Vig, V., 2008. "Did Securitization Lead to Lax Screening? Evidence from Subprime Loans," EFA 2008 Athens Meetings Paper, Athens 
La Porta, R., Lopez de Silanes, F. \& Shleifer, A., 2000. "Government Ownership of Banks," Harvard Institute of Economic Research Paper No. 1890, KSG Working Paper No. 01-016, Boston

Laeven, L. \& Valencia, F., 2008. "Systemic Banking Crises: A New Database," IMF Working Paper, WP/08/224, International Monetary Fund, Washington D.C.

Lee, S. \& Mullineaux, D., 2004. "Monitoring, Financial Distress and the Structure of Commercial Lending Syndicates," Financial Management, 33-3, pages 107-130

Leiringer, R., 2006. "Technological Innovation in PPPs: Incentives, Opportunities and Actions," Construction Management and Economics, 24(3), 301-308

Levine, R., Barth, J. \& Caprio, G., 2008. "Bank Regulation and Supervision," $3^{\text {rd }}$ update of the Bank Regulation and Supervision Database, June 2008, Finance and Private Sector Research, the World Bank, Washington D.C. 2005. "Rethinking

Bank Regulation: Till Angels Govern," Cambridge University Press

Regulation and Supervision: What Works Best?," World Bank Policy Research Working Paper No. 2725, the World Bank, Washington D.C.

Library of Congress, 2008. "Country profile: Mexico," Federal Research Division, July 2008.

Lorenzen, C., Barrientos, M. \& Babbar, S., 2004. "Toll Road Concessions: The Chilean experience," World Bank PFG Discussion Paper Series, No. 124, the World Bank, Washington D.C.

Mackenzie, G., 1998. "The Macroeconomic Impact of Privatization," IMF Staff Papers, International Monetary Fund, vol. 45(2), Washington D.C.

Maddala, G., 1983. "Limited Dependent and Qualitative Variables in Econometrics," Econometric Society Monographs, 3, Cambridge 
McFadden, D., 1984. "Econometric analysis of qualitative response models," Handbook of Econometrics, Elsevier, edition 1, volume 2, chapter 24, pages 1395-1457

McKelvey, R. \& Zavoina, W., 1975. "A Statistical Model for the Analysis of Ordinal Level Dependent Variables," Journal of Mathematical Sociology, 4, pp. 103120

Megginson, W. \& Netter, J., 2001. "From State to Market: A Survey of Empirical Studies on Privatization," Journal of Economic Literature, American Economic Association, vol. 39(2), pages 321-389

Merton, R., 1990. "The financial system and economic performance," Journal of Financial Services Research, 4 , pages 263-300

1977. "An analytic derivation of the cost of deposit insurance and loan guarantees. An application of modern option pricing theory," Journal of Banking and Finance, Elsevier, vol. 1(1), pages 3-11

\& Bodie, Z., 1992. "On the management of financial guarantees," Financial Management, Financial Management Association, vol. 21(4)

Modigliani, F. \& Miller, M., 1958. "The Cost of Capital, Corporation Finance and the Theory of Investment," American Economic Review, 48 (3), pages 261-297

Montgomery, H., 2005. "The Effectiveness of Bank Recapitalization in Japan," Hitotsubashi University, Research Unit for Statistical Analysis in Social Sciences (Hi-Stat), Discussion Paper No. 105, Tokyo

Moseley, F., 2009. "The U.S. economic crisis: Causes and solutions," International Socialist Review (ISR), Issue 64, March-April 2009, Chicago

Navarro, A., 2005. "The Treatment of Public-Private Partnership Assets in the GFSM 2001 Framework," IMF Research Paper, International Monetary Fund, Washington D.C. 
Organization for Economic Co-operation and Development (OECD), 2009a. "OECD Statistics Database," OECD StatExtracts, retrieved on December $30^{\text {th }} 2009$ from http://stats.oecd.org

2009b. "OECD Economic Surveys: Mexico," Organization for Economic Co-operation and Development, Volume 2009/11

2009c. "The Financial Crisis: Reform and exit strategies," Organization for Economic Co-operation and Development, OECD Publications, Paris

2008. "Public-Private Partnerships: In Pursuit of Risk Sharing and Value for Money," OECD Publications, Paris

2002. "OECD Best Practices for Budget Transparency," OECD Journal on Budgeting, 1(3), pages 7-14

Parker, D. \& Kirkpatrick, C., 2005. "Privatization in Developing Countries: A Review of the Evidence and the Policy Lessons," the Journal of Development Studies, Taylor and Francis Journals, vol. 41(4), pages 513-541 , \& Saal, D., 2003. "International Handbook on Privatization," Edward Elgar, Cheltenham

Pennacchi, G., 1987. "Alternative Forms of Deposit Insurance: Pricing and Bank Incentive Issues," Journal of Banking and Finance, 11, pages 291-312

People's Bank of China, 2008. "China Financial Stability Report," retrieved on December 30 2009 from www.pbc.gov.cn

Pettis, M., 2001. "The Volatility Machine: Emerging Economies and the Threat of Their Financial Collapse," New York: Oxford University Press

Pinheiro, A. \& Schneider, B. R., 1994. "The fiscal impact of privatization in Latin America," the Quarterly Review of Economics and Finance, Elsevier, vol. 34, pages 942

Pitelis, C. \& Clarke, T., 1993. "The Political Economy of Privatization," Routledge, London 
Quenouille, M., 1949. "Approximate Tests of Correlation in Time-Series," Journal of the Royal Statistical Society, Series B (Methodological), Vol. 11, No. 1, pages 6884

estimation," Biometrika, 43, pages 353-360

1956. "Notes on bias in

Reinhart, C. \& Rogoff, K., 2008. "Is the 2007 US Subprime Financial Crisis So Different? An International Historical Comparison," American Economic Review, American Economic Association, vol. 98(2), pages 339-44

Republic of Indonesia, 2009. "Government of Indonesia evaluation of the economy in 2008 and outlook for 2009," National Portal, Republic of Indonesia, retrieved on January $18^{\text {th }} 2010$ from www.indonesia.go.id

Ronn, E. \& Verma, A., 1986. "Pricing Risk-Adjusted Deposit Insurance: An Option-Based Model," Journal of Finance, 41, pages 871-895

Rosenberg, C., Halikias, I., House, B., Keller, C., Nystedt, J., Pitt, A. \& Setser, B., 2005. "Debt-Related Vulnerabilities and Financial Crises. An Application of the Balance Sheet Approach to Emerging Market Countries," IMF Occasional Paper, 240, International Monetary Fund, Washington D.C.

Sadka, E., 2006. "Public-Private Partnerships: A Public Economics Perspective," IMF Working Paper, WP/06/77, International Monetary Fund, Washington D.C.

Salanie, B., 1997. "The Economics of Contracts: A Primer," MIT Press, Cambridge MA

Saudi Arabian Monetary Agency, 2009. " $45^{\text {th }}$ Annual Report: The Latest Economic Developments," Saudi Arabian Monetary Agency, Research and Statistics Department, Riyadh

Schich, S., 2008. "Expanded Government Guarantees for Bank Liabilities: Selected Issues," Organization for Economic Co-operation and Development, OECD Publications, Paris 
Schwartz, P., 2008. "Banking Crisis Hits Germany with Full Force," International Committee of the Fourth International (ICFI), World Socialist Website, retrieved on December $30^{\text {th }} 2009$ from http:// www.wsws.org

Selby, M., Franks, J. \& Karki, J., 1988. "Loan Guarantees, Wealth Transfers and Incentives to Invest," Journal of Industrial Economics, 37, pages 47-65

Sharpe, W., 1978. "Bank Capital Adequacy, Deposit Insurance and Security Values," Journal of Financial and Quantitative Analysis, 13, pages 701-718

Sosin, H., 1980. "On the Valuation of Federal Loan Guarantees to Corporations," Journal of Finance, 35, pages 1209-1221

Spilimbergo, A., Symansky, S., Blanchard, O. \& Cottarelli, C., 2008. "Fiscal Policy for the Crisis," IMF Staff Position Note 08/01, International Monetary Fund, Washington D.C.

Standard \& Poor's, 2009a. "Standard and Poor's Ratings Definitions," 30/04/2009, www.standardandpoors.com, New York

— 2009b. "Understanding Standard and Poor's Ratings Definitions," 03/06/2009, www.standardandpoors.com, New York

Stickney, C. \& Weil, R., 2000. "Financial Accounting: An Introduction to Concepts, Methods and Uses," Dryden Press, Chicago

Sufi, A., 2007. "Information Asymmetry and Financing Arrangements: Evidence from Syndicated Loans," the Journal of Finance, volume 62, issue 2, pages 629-668

Tirole, J., 1999. "Incomplete Contracts: Where Do We Stand?," Econometrica, vol. 67 (4), pages 741-781

Torres, L. \& Pina, V., 2001. "Public-private partnership and private finance initiatives in the EU and Spanish local governments," European Accounting Review, Taylor and Francis Journals, vol. 10 (3), pages 601-619 
Trujillo, L., Martin Morales, N., Estache, A. \& Campos, J., 2002. "Macroeconomic Effects of Private Sector Participation in Latin America's Infrastructure," World Bank Policy Research Working Paper, No. 2906, the World Bank, Washington D.C.

Tukey, J. W., 1958. "Bias and confidence in not-quite large samples," Annals of Mathematical Statistics, 29, page 614

Turkish Embassy London, 2009. "Economic Outlook of Turkey," Office of the First Economic Counselor, retrieved on December 30 2009 from www.turkisheconomy.org.uk

U.S. Department of State, 2009. "Background Note: Russia," U.S. Department of State, Bureau of European and Eurasian Affairs, retrieved on December 30 2009 from www.pbc.gov.cn

Velasco, A., 2008. "Public Finance Report 2008," Ministry of Finance of Chile, www.hacienda.gov.cl, Santiago

Webb, R. \& Pulle, B., 2003. "Public-Private Partnerships: An Introduction," Department of the Parliamentary Library, Research Paper No. 1, 2002-2003

World Bank, 2008. "Indonesia: Economic and Social update," April 2008, the World Bank, Washington D.C. and International Monetary Fund, 2001.

"Developing a Government Bond Market: An Overview," the World Bank and the International Monetary Fund, Chapter 1, Washington D.C.

Xenopohon, 431 BC. "The Economist (1)," The Works of Xenophon, pages 13-15

Zitron, J., 2006. "Public-private Partnership Projects: Towards a Model of Contractor Bidding Decision-making," Journal of Purchasing and Supply Management, 12, pages 5362 


\section{Appendices}

Appendix 3-A: Nominal and discounted values of guarantees, expected revenues and net contingent flows

Appendix 3-A / Table 1: Minimum income guarantees per section for

Route 5 projects, nominal values in million CH\$, years 1998-2007

\begin{tabular}{|c|c|c|c|c|c|c|c|c|c|}
\hline Year & $\begin{array}{c}\text { Talca - } \\
\text { Chillan }\end{array}$ & $\begin{array}{c}\text { Santiago } \\
- \text { Los } \\
\text { Vilos }\end{array}$ & $\begin{array}{c}\text { La } \\
\text { Serena } \\
- \text { Los } \\
\text { Vilos }\end{array}$ & $\begin{array}{c}\text { Chillan - } \\
\text { Collipulli }\end{array}$ & $\begin{array}{c}\text { Temuco } \\
- \text { Rio } \\
\text { Bueno }\end{array}$ & $\begin{array}{c}\text { Rio } \\
\text { Bueno- } \\
\text { Puerto } \\
\text { Montt }\end{array}$ & $\begin{array}{c}\text { Collipulli } \\
- \\
\text { Temuco }\end{array}$ & $\begin{array}{c}\text { Santiago } \\
- \text { Talca }\end{array}$ & $\begin{array}{c}\text { Total } \\
\text { for } \\
\text { year }\end{array}$ \\
\hline $\mathbf{1 9 9 8}$ & 0 & 0 & 0 & 0 & 0 & 0 & 0 & 0 & $\mathbf{0}$ \\
\hline $\mathbf{1 9 9 9}$ & 0 & 0 & 0 & 0 & 0 & 0 & 0 & 0 & $\mathbf{0}$ \\
\hline $\mathbf{2 0 0 0}$ & 0 & 0 & 3.767 & 0 & 0 & 0 & 0 & 0 & $\mathbf{3 . 7 6 7}$ \\
\hline $\mathbf{2 0 0 1}$ & 14.401 & 12.043 & 5.469 & 5.965 & 4.765 & 3.678 & 0 & 0 & $\mathbf{4 6 . 3 2 0}$ \\
\hline $\mathbf{2 0 0 2}$ & 16.005 & 13.338 & 5.880 & 6.421 & 5.127 & 3.964 & 8.239 & 23.325 & $\mathbf{8 2 . 3 0 0}$ \\
\hline $\mathbf{2 0 0 3}$ & 17.909 & 14.854 & 6.368 & 6.960 & 5.541 & 4.291 & 8.919 & 25.271 & $\mathbf{9 0 . 1 1 1}$ \\
\hline $\mathbf{2 0 0 4}$ & 19.590 & 16.167 & 6.744 & 7.357 & 5.875 & 4.547 & 9.435 & 26.738 & $\mathbf{9 6 . 4 5 3}$ \\
\hline $\mathbf{2 0 0 5}$ & 21.874 & 17.968 & 7.291 & 7.957 & 6.344 & 4.907 & 10.200 & 28.900 & $\mathbf{1 0 5 . 4 4 1}$ \\
\hline $\mathbf{2 0 0 6}$ & 24.215 & 20.106 & 7.937 & 8.663 & 6.902 & 5.340 & 11.097 & 31.439 & $\mathbf{1 1 5 . 6 9 9}$ \\
\hline $\mathbf{2 0 0 7}$ & 26.048 & 22.467 & 8.624 & 9.395 & 7.497 & 5.806 & 12.044 & 34.159 & $\mathbf{1 2 6 . 0 4 0}$ \\
\hline Total & $\mathbf{1 4 0 . 0 4 2}$ & $\mathbf{1 1 6 . 9 4 2}$ & $\mathbf{5 2 . 0 8 1}$ & $\mathbf{5 2 . 7 1 7}$ & $\mathbf{4 2 . 0 5 1}$ & $\mathbf{3 2 . 5 3 3}$ & $\mathbf{5 9 . 9 3 4}$ & $\mathbf{1 6 9 . 8 3 2}$ & $\mathbf{6 6 6 . 1 3 3}$ \\
\hline
\end{tabular}

Appendix 3-A / Table 2: Minimum income guarantees per section for Route 5 projects, discounted values in million CH\$, years 1998-2007

\begin{tabular}{|l|c|c|c|c|c|c|c|c|c|}
\hline Year & $\begin{array}{c}\text { Talca - } \\
\text { Chillan }\end{array}$ & $\begin{array}{c}\text { Santiago } \\
- \text { Los } \\
\text { Vilos }\end{array}$ & $\begin{array}{c}\text { La } \\
\text { Serena } \\
- \text { Los } \\
\text { Vilos }\end{array}$ & $\begin{array}{c}\text { Chillan - } \\
\text { Collipulli }\end{array}$ & $\begin{array}{c}\text { Temuco } \\
- \text { Rio } \\
\text { Bueno }\end{array}$ & $\begin{array}{c}\text { Rio } \\
\text { Bueno- } \\
\text { Puerto } \\
\text { Montt }\end{array}$ & $\begin{array}{c}\text { Collipulli } \\
- \\
\text { Temuco }\end{array}$ & $\begin{array}{c}\text { Santiago } \\
\text { - Talca }\end{array}$ & $\begin{array}{c}\text { Total } \\
\text { for } \\
\text { year }\end{array}$ \\
\hline $\mathbf{1 9 9 8}$ & 0 & 0 & 0 & 0 & 0 & 0 & 0 & 0 & $\mathbf{0}$ \\
\hline $\mathbf{1 9 9 9}$ & 0 & 0 & 0 & 0 & 0 & 0 & 0 & 0 & $\mathbf{0}$ \\
\hline $\mathbf{2 0 0 0}$ & 0 & 0 & 3.110 & 0 & 0 & 0 & 0 & 0 & $\mathbf{3 . 1 1 0}$ \\
\hline $\mathbf{2 0 0 1}$ & 10.802 & 9.477 & 4.303 & 4.924 & 3.934 & 3.036 & 0 & 0 & $\mathbf{3 6 . 4 7 5}$ \\
\hline $\mathbf{2 0 0 2}$ & 11.443 & 10.004 & 4.411 & 5.053 & 4.034 & 3.119 & 6.483 & 19.256 & $\mathbf{6 3 . 8 0 3}$ \\
\hline $\mathbf{2 0 0 3}$ & 12.205 & 10.620 & 4.553 & 5.220 & 4.156 & 3.218 & 6.690 & 19.885 & $\mathbf{6 6 . 5 4 7}$ \\
\hline $\mathbf{2 0 0 4}$ & 12.726 & 11.018 & 4.596 & 5.260 & 4.201 & 3.251 & 6.746 & 20.055 & $\mathbf{6 7 . 8 5 2}$ \\
\hline $\mathbf{2 0 0 5}$ & 13.544 & 11.672 & 4.736 & 5.423 & 4.324 & 3.344 & 6.951 & 20.663 & $\mathbf{7 0 . 6 5 7}$ \\
\hline $\mathbf{2 0 0 6}$ & 14.292 & 12.450 & 4.915 & 5.628 & 4.483 & 3.469 & 7.209 & 21.426 & $\mathbf{7 3 . 8 7 1}$ \\
\hline $\mathbf{2 0 0 7}$ & 14.655 & 13.261 & 5.090 & 5.817 & 4.642 & 3.595 & 7.458 & 22.190 & $\mathbf{7 6 . 7 0 7}$ \\
\hline Total & $\mathbf{8 9 . 6 6 6}$ & $\mathbf{7 8 . 5 0 0}$ & $\mathbf{3 5 . 7 1 4}$ & $\mathbf{3 7 . 3 2 4}$ & $\mathbf{2 9 . 7 7 4}$ & $\mathbf{2 3 . 0 3 3}$ & $\mathbf{4 1 . 5 3 7}$ & $\mathbf{1 2 3 . 4 7 4}$ & $\mathbf{4 5 9 . 0 2 3}$ \\
\hline
\end{tabular}


Appendix 3-A / Table 3: Expected revenue per section for Route 5

\begin{tabular}{|l|c|c|c|c|c|c|c|c|c|}
\hline \multicolumn{7}{|c|}{ projects, nominal values in million CH\$, years 1998-2007 } \\
\hline Year & $\begin{array}{c}\text { Talca - } \\
\text { Chillan }\end{array}$ & $\begin{array}{c}\text { Santiago } \\
\text { - Los } \\
\text { Vilos }\end{array}$ & $\begin{array}{c}\text { La } \\
\text { Serena } \\
\text { - Los } \\
\text { Vilos }\end{array}$ & $\begin{array}{c}\text { Chillan - } \\
\text { Collipulli }\end{array}$ & $\begin{array}{c}\text { Temuco } \\
\text { - Rio } \\
\text { Bueno }\end{array}$ & $\begin{array}{c}\text { Rio } \\
\text { Bueno - } \\
\text { Puerto } \\
\text { Montt }\end{array}$ & $\begin{array}{c}\text { Collipulli } \\
- \\
\text { Temuco }\end{array}$ & $\begin{array}{c}\text { Santiago } \\
\text { - Talca }\end{array}$ & $\begin{array}{c}\text { Total } \\
\text { for } \\
\text { year }\end{array}$ \\
\hline $\mathbf{1 9 9 8}$ & 8.199 & 0 & 0 & 0 & 0 & 0 & 0 & 0 & $\mathbf{1 5 . 7 6 8}$ \\
\hline $\mathbf{1 9 9 9}$ & 8.199 & 9.517 & 0 & 0 & 0 & 0 & 0 & 0 & $\mathbf{3 4 . 0 6 9}$ \\
\hline $\mathbf{2 0 0 0}$ & 8.199 & 9.517 & 2.705 & 0 & 0 & 0 & 0 & 0 & $\mathbf{3 9 . 2 7 0}$ \\
\hline $\mathbf{2 0 0 1}$ & 8.199 & 9.517 & 2.705 & 4.479 & 2.856 & 3.743 & 0 & 0 & $\mathbf{6 0 . 5 7 5}$ \\
\hline $\mathbf{2 0 0 2}$ & 8.199 & 9.517 & 2.705 & 4.479 & 2.856 & 3.743 & 4.409 & 22.719 & $\mathbf{1 1 2 . 7 4 4}$ \\
\hline $\mathbf{2 0 0 3}$ & 8.199 & 9.517 & 2.705 & 4.479 & 2.856 & 3.743 & 4.409 & 22.719 & $\mathbf{1 1 2 . 7 4 4}$ \\
\hline $\mathbf{2 0 0 4}$ & 8.199 & 9.517 & 2.705 & 4.479 & 2.856 & 3.743 & 4.409 & 22.719 & $\mathbf{1 1 2 . 7 4 4}$ \\
\hline $\mathbf{2 0 0 5}$ & 8.199 & 9.517 & 2.705 & 4.479 & 2.856 & 3.743 & 4.409 & 22.719 & $\mathbf{1 1 2 . 7 4 4}$ \\
\hline $\mathbf{2 0 0 6}$ & 8.199 & 9.517 & 2.705 & 4.479 & 2.856 & 3.743 & 4.409 & 22.719 & $\mathbf{1 1 2 . 7 4 4}$ \\
\hline $\mathbf{2 0 0 7}$ & 8.199 & 9.517 & 2.705 & 4.479 & 2.856 & 3.743 & 4.409 & 22.719 & $\mathbf{1 1 2 . 7 4 4}$ \\
\hline Total & $\mathbf{8 1 . 9 9 0}$ & $\mathbf{8 5 . 6 5 3}$ & $\mathbf{2 1 . 6 4 0}$ & $\mathbf{3 1 . 3 5 3}$ & $\mathbf{1 9 . 9 9 2}$ & $\mathbf{2 6 . 2 0 1}$ & $\mathbf{2 6 . 4 5 4}$ & $\mathbf{1 3 6 . 3 1 4}$ & $\mathbf{8 2 6 . 1 4 6}$ \\
\hline
\end{tabular}

Appendix 3-A / Table 4: Expected revenue per section for Route 5 projects, discounted values in million CH\$, years 1998-2007

\begin{tabular}{|l|c|c|c|c|c|c|c|c|c|}
\hline Year & $\begin{array}{c}\text { Talca - } \\
\text { Chillan }\end{array}$ & $\begin{array}{c}\text { Santiago } \\
- \text { Los } \\
\text { Vilos }\end{array}$ & $\begin{array}{c}\text { La } \\
\text { Serena } \\
- \text { Los } \\
\text { Vilos }\end{array}$ & $\begin{array}{c}\text { Chillan - } \\
\text { Collipulli }\end{array}$ & $\begin{array}{c}\text { Temuco } \\
- \text { Rio } \\
\text { Bueno }\end{array}$ & $\begin{array}{c}\text { Rio } \\
\text { Bueno } \\
- \\
\text { Puerto } \\
\text { Montt }\end{array}$ & $\begin{array}{c}\text { Collipulli } \\
- \\
\text { Temuco }\end{array}$ & $\begin{array}{c}\text { Santiago } \\
- \text { Talca }\end{array}$ & $\begin{array}{c}\text { Total for } \\
\text { year }\end{array}$ \\
\hline $\mathbf{1 9 9 8}$ & 7.101 & 0 & 0 & 0 & 0 & 0 & 0 & 0 & $\mathbf{7 . 1 0 1}$ \\
\hline $\mathbf{1 9 9 9}$ & 6.769 & 8.242 & 0 & 0 & 0 & 0 & 0 & 0 & $\mathbf{1 5 . 0 1 1}$ \\
\hline $\mathbf{2 0 0 0}$ & 6.452 & 7.857 & 2.233 & 0 & 0 & 0 & 0 & 0 & $\mathbf{1 6 . 5 4 1}$ \\
\hline $\mathbf{2 0 0 1}$ & 6.150 & 7.489 & 2.129 & 3.698 & 2.358 & 3.090 & 0 & 0 & $\mathbf{2 4 . 9 1 2}$ \\
\hline $\mathbf{2 0 0 2}$ & 5.862 & 7.138 & 2.029 & 3.524 & 2.247 & 2.945 & 3.469 & 18.755 & $\mathbf{4 5 . 9 7 1}$ \\
\hline $\mathbf{2 0 0 3}$ & 5.588 & 6.804 & 1.934 & 3.360 & 2.142 & 2.807 & 3.307 & 17.877 & $\mathbf{4 3 . 8 2 0}$ \\
\hline $\mathbf{2 0 0 4}$ & 5.326 & 6.486 & 1.843 & 3.202 & 2.042 & 2.676 & 3.152 & 17.041 & $\mathbf{4 1 . 7 6 9}$ \\
\hline $\mathbf{2 0 0 5}$ & 5.077 & 6.182 & 1.757 & 3.052 & 1.946 & 2.551 & 3.005 & 16.243 & $\mathbf{3 9 . 8 1 4}$ \\
\hline $\mathbf{2 0 0 6}$ & 4.839 & 5.893 & 1.675 & 2.910 & 1.855 & 2.431 & 2.864 & 15.483 & $\mathbf{3 7 . 9 5 0}$ \\
\hline $\mathbf{2 0 0 7}$ & 4.613 & 5.617 & 1.597 & 2.773 & 1.768 & 2.318 & 2.730 & 14.758 & $\mathbf{3 6 . 1 7 4}$ \\
\hline Total & $\mathbf{5 7 . 7 7 5}$ & $\mathbf{6 1 . 7 0 9}$ & $\mathbf{1 5 . 1 9 7}$ & $\mathbf{2 2 . 5 1 9}$ & $\mathbf{1 4 . 3 5 9}$ & $\mathbf{1 8 . 8 1 9}$ & $\mathbf{1 8 . 5 2 8}$ & $\mathbf{1 0 0 . 1 5 8}$ & $\mathbf{3 0 9 . 0 6 3}$ \\
\hline
\end{tabular}

Appendix 3-A / Table 5: Detailed table of guarantees, expected revenues and net contingent flows for Route 5 projects, discounted values in million CH\$, years 1998-2007
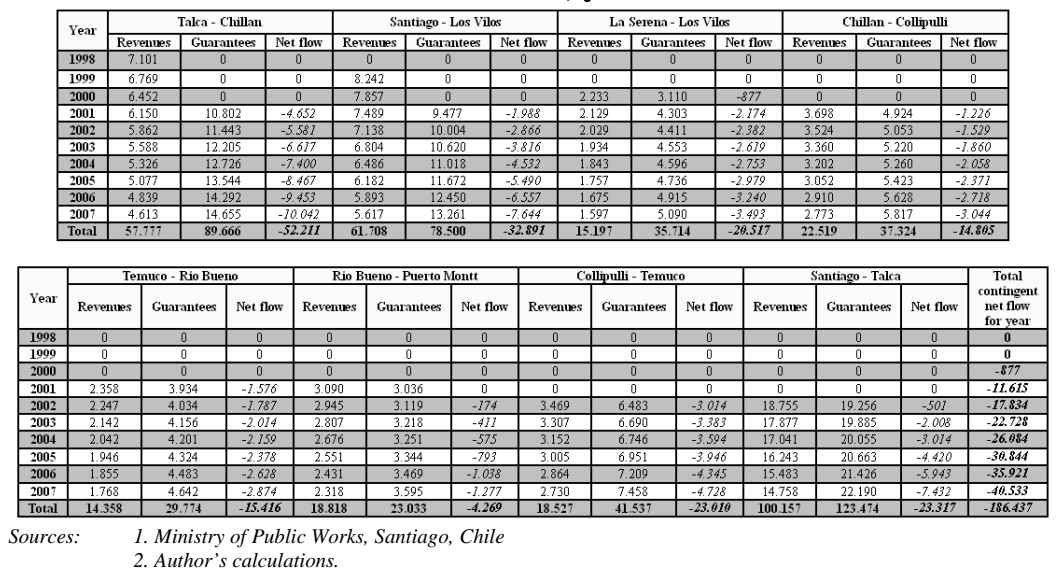
Appendix 3-B: Government deficit/surplus and GDP / gross debt, typical public investment vs. public-private partnership

Appendix 3-B / Table 1: Chilean government surplus / deficit, investment cost, project revenues, cumulative values, million $\mathrm{CH}$, years 1990-2007

\begin{tabular}{|c|c|c|c|c|}
\hline Year & $\begin{array}{c}\text { Chilean } \\
\text { government } \\
\text { deficit/surplus }\end{array}$ & $\begin{array}{c}\text { Estimated } \\
\text { investment } \\
\text { cost }\end{array}$ & $\begin{array}{c}\text { Expected project } \\
\text { revenue, } \\
\text { discounted }\end{array}$ & $\begin{array}{c}\text { Deficit/surplus including } \\
\text { the project revenue / } \\
\text { cost }\end{array}$ \\
\hline $\mathbf{1 9 9 0}$ & 234.554 & 0 & 0 & 234.554 \\
\hline $\mathbf{1 9 9 1}$ & 436.574 & 0 & 0 & 436.574 \\
\hline $\mathbf{1 9 9 2}$ & 780.530 & 0 & 0 & 780.530 \\
\hline $\mathbf{1 9 9 3}$ & 1.054 .470 & 0 & 0 & 1.054 .470 \\
\hline $\mathbf{1 9 9 4}$ & 1.402 .619 & 0 & 0 & 1.402 .619 \\
\hline $\mathbf{1 9 9 5}$ & 2.282 .497 & -72.609 & 0 & 2.209 .888 \\
\hline $\mathbf{1 9 9 6}$ & 2.967 .672 & -293.995 & 0 & 2.673 .677 \\
\hline $\mathbf{1 9 9 7}$ & 3.677 .008 & -662.144 & 0 & 2.014 .864 \\
\hline $\mathbf{1 9 9 8}$ & 3.827 .948 & -1.007 .362 & 7.101 & 2.827 .687 \\
\hline $\mathbf{1 9 9 9}$ & 3.037 .457 & -1.007 .362 & 22.112 & 1.801 .666 \\
\hline $\mathbf{2 0 0 0}$ & 2.770 .375 & -1.007 .362 & 38.653 & 1.593 .831 \\
\hline $\mathbf{2 0 0 1}$ & 2.537 .628 & -1.007 .362 & 63.565 & 1.064 .980 \\
\hline $\mathbf{2 0 0 2}$ & 1.962 .806 & -1.007 .362 & 109.536 & 878.330 \\
\hline $\mathbf{2 0 0 3}$ & 1.732 .336 & -1.007 .362 & 153.356 & 2.164 .559 \\
\hline $\mathbf{2 0 0 4}$ & 2.976 .796 & -1.007 .362 & 195.125 & 5.226 .112 \\
\hline $\mathbf{2 0 0 5}$ & 5.998 .536 & -1.007 .362 & 234.938 & 11.248 .163 \\
\hline $\mathbf{2 0 0 6}$ & 11.982 .636 & -1.007 .362 & 272.889 & 18.835 .417 \\
\hline $\mathbf{2 0 0 7}$ & 19.533 .716 & -1.007 .362 & 309.063 & \\
\hline Sources: & 1. Ministry of Finance, Ministry of Public Works, Santiago, Chile & \\
\hline
\end{tabular}


Appendix 3-B / Table 2: Chilean government deficit/surplus, Typical

Public Investment vs. Public-Private Partnership, cumulative values, million CH\$, years 1990-2007

\begin{tabular}{|c|c|c|c|}
\hline Year & $\begin{array}{c}\text { Chilean government } \\
\text { deficit/surplus } \\
\text { Typical Public Investment }\end{array}$ & $\begin{array}{c}\text { Chilean government } \\
\text { deficit/surplus } \\
\text { Public-Private Partnership }\end{array}$ & $\begin{array}{c}\text { Difference, } \\
\text { Typical Public Investment vs } \\
\text { Public-Private Partnership }\end{array}$ \\
\hline $\mathbf{1 9 9 0}$ & 234.554 & 234.554 & 0 \\
\hline $\mathbf{1 9 9 1}$ & 436.574 & 436.574 & 0 \\
\hline $\mathbf{1 9 9 2}$ & 780.530 & 780.530 & 0 \\
\hline $\mathbf{1 9 9 3}$ & 1.054 .470 & 1.054 .470 & 0 \\
\hline $\mathbf{1 9 9 4}$ & 1.402 .619 & 1.402 .619 & -72.609 \\
\hline $\mathbf{1 9 9 5}$ & 2.209 .888 & 2.282 .497 & -293.995 \\
\hline $\mathbf{1 9 9 6}$ & 2.673 .677 & 2.967 .672 & -662.144 \\
\hline $\mathbf{1 9 9 7}$ & 3.014 .864 & 3.677 .008 & -1.000 .261 \\
\hline $\mathbf{1 9 9 8}$ & 2.827 .687 & 3.827 .948 & -985.250 \\
\hline $\mathbf{1 9 9 9}$ & 2.052 .207 & 3.037 .457 & -968.709 \\
\hline $\mathbf{2 0 0 0}$ & 1.801 .666 & 2.770 .375 & -943.797 \\
\hline $\mathbf{2 0 0 1}$ & 1.593 .831 & 2.537 .628 & -897.826 \\
\hline $\mathbf{2 0 0 2}$ & 1.064 .980 & 1.962 .806 & -854.006 \\
\hline $\mathbf{2 0 0 3}$ & 878.330 & 1.732 .336 & -812.237 \\
\hline $\mathbf{2 0 0 4}$ & 2.164 .559 & 2.976 .796 & -772.423 \\
\hline $\mathbf{2 0 0 5}$ & 5.226 .113 & 5.998 .536 & -734.473 \\
\hline $\mathbf{2 0 0 6}$ & 11.248 .163 & 11.982 .636 & -698.299 \\
\hline $\mathbf{2 0 0 7}$ & 18.835 .417 & 19.533 .716 & \\
\hline & Sources: & & \\
\hline
\end{tabular}

Appendix 3-B / Table 3: Chilean GDP, gross consolidated debt, debt to

GDP ratio, nominal values in million CH\$, years 1990-2007

\begin{tabular}{|l|c|c|c|}
\hline Year & Gross domestic product - GDP & Gross donsolidated debt & Debt to GDP ratio \\
\hline $\mathbf{1 9 9 0}$ & 9.622 .320 & 7.268 .154 & 0,7553 \\
\hline $\mathbf{1 9 9 1}$ & 12.720 .050 & 8.290 .584 & 0,6518 \\
\hline $\mathbf{1 9 9 2}$ & 16.123 .190 & 9.329 .348 & 0,5786 \\
\hline $\mathbf{1 9 9 3}$ & 19.276 .480 & 10.245 .373 & 0,5315 \\
\hline $\mathbf{1 9 9 4}$ & 23.174 .700 & 11.482 .681 & 0,4955 \\
\hline $\mathbf{1 9 9 5}$ & 28.309 .220 & 11.406 .113 & 0,4029 \\
\hline $\mathbf{1 9 9 6}$ & 31.237 .810 & 11.636 .834 & 0,3725 \\
\hline $\mathbf{1 9 9 7}$ & 34.721 .180 & 12.966 .890 & 0,3735 \\
\hline $\mathbf{1 9 9 8}$ & 36.531 .930 & 12.510 .701 & 0,3425 \\
\hline $\mathbf{1 9 9 9}$ & 37.135 .200 & 13.261 .260 & 0,3571 \\
\hline $\mathbf{2 0 0 0}$ & 40.569 .870 & 14.680 .707 & 0,3619 \\
\hline $\mathbf{2 0 0 1}$ & 43.528 .780 & 15.934 .077 & 0,3661 \\
\hline $\mathbf{2 0 0 2}$ & 46.332 .060 & 16.856 .224 & 0,3638 \\
\hline $\mathbf{2 0 0 3}$ & 51.156 .760 & 17.082 .983 & 0,3339 \\
\hline $\mathbf{2 0 0 4}$ & 58.302 .580 & 16.727 .407 & 0,2869 \\
\hline $\mathbf{2 0 0 5}$ & 66.192 .600 & 16.192 .976 & 0,2446 \\
\hline $\mathbf{2 0 0 6}$ & 77.651 .820 & 15.131 .141 & 0,1949 \\
\hline $\mathbf{2 0 0 7}$ & 85.639 .830 & 12.515 .102 & 0,1461 \\
\hline & I. International Monetary Fund, Washington-DC, U.S.A. & \\
\hline & Sources: Banco Central de Chile, Santiago, Chile & \\
\hline
\end{tabular}


Appendix 3-B / Table 4: Chilean government deficit/surplus, nominal values in million CH\$, years 1990-2007

\begin{tabular}{|c|c|c|c|}
\hline Year & $\begin{array}{c}\text { Chilean government } \\
\text { revenue }\end{array}$ & $\begin{array}{c}\text { Chilean government } \\
\text { outlays }\end{array}$ & $\begin{array}{c}\text { Chilean government } \\
\text { deficit/surplus }\end{array}$ \\
\hline $\mathbf{1 9 9 0}$ & 2.222 .941 & 1.988 .387 & $\mathbf{2 3 4 . 5 5 4}$ \\
\hline $\mathbf{1 9 9 1}$ & 2.865 .786 & 2.663 .766 & $\mathbf{2 0 2 . 0 2 0}$ \\
\hline $\mathbf{1 9 9 2}$ & 3.626 .607 & 3.282 .651 & $\mathbf{3 4 3 . 9 5 6}$ \\
\hline $\mathbf{1 9 9 3}$ & 4.231 .046 & 3.957 .106 & $\mathbf{2 7 3 . 9 4 0}$ \\
\hline $\mathbf{1 9 9 4}$ & 4.962 .354 & 4.614 .205 & $\mathbf{3 4 8 . 1 4 9}$ \\
\hline $\mathbf{1 9 9 5}$ & 6.165 .217 & 5.285 .339 & $\mathbf{8 7 9 . 8 7 8}$ \\
\hline $\mathbf{1 9 9 6}$ & 6.816 .197 & 6.131 .022 & $\mathbf{6 8 5 . 1 7 5}$ \\
\hline $\mathbf{1 9 9 7}$ & 7.518 .809 & 6.809 .473 & $\mathbf{7 0 9 . 3 3 6}$ \\
\hline $\mathbf{1 9 9 8}$ & 7.721 .997 & 7.571 .057 & $\mathbf{1 5 0 . 9 4 0}$ \\
\hline $\mathbf{1 9 9 9}$ & 7.577 .737 & 8.368 .228 & $\mathbf{- 7 9 0 . 4 9 1}$ \\
\hline $\mathbf{2 0 0 0}$ & 8.787 .365 & 9.054 .447 & $\mathbf{- 2 6 7 . 0 8 2}$ \\
\hline $\mathbf{2 0 0 1}$ & 9.478 .039 & 9.710 .786 & $\mathbf{- 5 3 2 . 7 4 7}$ \\
\hline $\mathbf{2 0 0 2}$ & 9.793 .318 & 10.368 .140 & $\mathbf{- 2 3 0 . 4 7 0}$ \\
\hline $\mathbf{2 0 0 3}$ & 10.597 .600 & 10.828 .070 & $\mathbf{1 . 2 4 4 . 4 6 0}$ \\
\hline $\mathbf{2 0 0 4}$ & 12.853 .180 & 11.608 .720 & $\mathbf{3 . 0 2 1 . 7 4 0}$ \\
\hline $\mathbf{2 0 0 5}$ & 15.773 .790 & 12.752 .050 & $\mathbf{5 . 9 8 4 . 1 0 0}$ \\
\hline $\mathbf{2 0 0 6}$ & 20.079 .090 & 14.094 .990 & $\mathbf{7 . 5 5 1 . 0 8 0}$ \\
\hline $\mathbf{2 0 0 7}$ & 23.546 .720 & 15.995 .640 & \\
\hline Sources: & 1. Ministry of Finance, Santiago, Chile & & \\
\hline & & & \\
\hline
\end{tabular}

Appendix 3-B / Table 5: Chilean government deficit/surplus and total net contingent flows, cumulative values, million CH\$, years 1990-2007

\begin{tabular}{|c|c|c|c|}
\hline Year & $\begin{array}{c}\text { Chilean } \\
\text { government } \\
\text { deficit/surplus }\end{array}$ & $\begin{array}{c}\text { Total net } \\
\text { contingent flow for } \\
\text { year }\end{array}$ & $\begin{array}{c}\text { Chilean government } \\
\text { deficit/surplus including net } \\
\text { contingent flow }\end{array}$ \\
\hline $\mathbf{1 9 9 0}$ & 234.554 & 0 & 234.554 \\
\hline $\mathbf{1 9 9 1}$ & 436.574 & 0 & 436.574 \\
\hline $\mathbf{1 9 9 2}$ & 780.530 & 0 & 780.530 \\
\hline $\mathbf{1 9 9 3}$ & 1.054 .470 & 0 & 1.054 .470 \\
\hline $\mathbf{1 9 9 4}$ & 1.402 .619 & 0 & 1.402 .619 \\
\hline $\mathbf{1 9 9 5}$ & 2.282 .497 & 0 & 2.282 .497 \\
\hline $\mathbf{1 9 9 6}$ & 2.967 .672 & 0 & 2.967 .672 \\
\hline $\mathbf{1 9 9 7}$ & 3.677 .008 & 0 & 3.677 .008 \\
\hline $\mathbf{1 9 9 8}$ & 3.827 .948 & 0 & 3.827 .948 \\
\hline $\mathbf{1 9 9 9}$ & 3.037 .457 & 0 & 3.037 .457 \\
\hline $\mathbf{2 0 0 0}$ & 2.770 .375 & -877 & 2.769 .498 \\
\hline $\mathbf{2 0 0 1}$ & 2.537 .628 & -12.492 & 2.525 .136 \\
\hline $\mathbf{2 0 0 2}$ & 1.962 .806 & -30.326 & 1.932 .480 \\
\hline $\mathbf{2 0 0 3}$ & 1.732 .336 & -53.054 & 1.679 .282 \\
\hline $\mathbf{2 0 0 4}$ & 2.976 .796 & -79.138 & 2.897 .658 \\
\hline $\mathbf{2 0 0 5}$ & 5.998 .536 & -109.982 & 5.888 .554 \\
\hline $\mathbf{2 0 0 6}$ & 11.982 .636 & -145.903 & 11.836 .733 \\
\hline $\mathbf{2 0 0 7}$ & 19.533 .716 & -186.436 & 19.347 .280 \\
\hline Sources: & 1. Ministry of Finance, Ministry of Public Works, Santiago, Chile & \\
\hline
\end{tabular}




\section{Appendix 3-C: Normality Tests}

Appendix 3-C / Box 1: Normality tests for guarantees (Shapiro - Wilk, Anderson - Darling, Lilliefors, Jarque - Bera)

\begin{tabular}{|c|c|c|c|}
\hline \multicolumn{2}{|c|}{ Shapiro-Wilk test (Guarantees): } & \multicolumn{2}{|c|}{ Anderson-Darling test (Guarantees): } \\
\hline $\mathrm{W}$ & 1,000 & $\mathrm{~A}^{2}$ & 0,208 \\
\hline $\mathrm{p}$-value & 0,752 & $\mathrm{p}$-value & 0,867 \\
\hline Alpha & 0,05 & Alpha & 0,05 \\
\hline \multicolumn{2}{|c|}{ Lilliefors test (Guarantees): } & \multicolumn{2}{|c|}{ Jarque-Bera test (Guarantees): } \\
\hline $\mathrm{D}$ & 0,005 & JB (Observed value) & 0,646 \\
\hline D (standardized) & 0,498 & JB (Critical value) & 5,991 \\
\hline p-value & 0,793 & DF & 2 \\
\hline \multirow[t]{2}{*}{ Alpha } & 0,05 & $\mathrm{p}$-value & 0,724 \\
\hline & & Alpha & 0,05 \\
\hline
\end{tabular}

Appendix 3-C / Box 2: Normality tests for expected revenues (Shapiro - Wilk, Anderson - Darling, Lilliefors, Jarque - Bera)

\begin{tabular}{|c|c|c|c|}
\hline \multicolumn{2}{|c|}{ Shapiro-Wilk test (Revenues): } & \multicolumn{2}{|c|}{ Anderson-Darling test (Revenues): } \\
\hline $\mathrm{W}$ & 1,000 & $\mathrm{~A}^{2}$ & 0,320 \\
\hline p-value & 0,941 & p-value & 0,532 \\
\hline Alpha & 0,05 & Alpha & 0,05 \\
\hline \multicolumn{2}{|c|}{ Lilliefors test (Revenues): } & \multicolumn{2}{|c|}{ Jarque-Bera test (Revenues): } \\
\hline $\mathrm{D}$ & 0,006 & JB (Observed value) & 0,050 \\
\hline D (standardized) & 0,608 & JB (Critical value) & 5,991 \\
\hline p-value & 0,495 & $\mathrm{DF}$ & 2 \\
\hline \multirow[t]{2}{*}{ Alpha } & 0,05 & p-value & 0,975 \\
\hline & & Alpha & 0,05 \\
\hline
\end{tabular}


Appendix 3-C / Box 3: Normality tests for consolidated assets (Shapiro - Wilk, Anderson - Darling, Lilliefors, Jarque - Bera)

\begin{tabular}{|c|c|c|c|}
\hline \multicolumn{2}{|c|}{ Shapiro-Wilk test (Assets): } & \multicolumn{2}{|c|}{ Anderson-Darling test (Assets): } \\
\hline $\mathrm{W}$ & 1,000 & $\mathrm{~A}^{2}$ & 0,522 \\
\hline p-value & 0,474 & p-value & 0,184 \\
\hline Alpha & 0,05 & Alpha & 0,05 \\
\hline \multicolumn{2}{|c|}{ Lilliefors test (Assets): } & \multicolumn{2}{|c|}{ Jarque-Bera test (Assets): } \\
\hline $\mathrm{D}$ & 0,007 & JB (Observed value) & 0,176 \\
\hline D (standardized) & 0,679 & JB (Critical value) & 5,991 \\
\hline p-value & 0,320 & DF & 2 \\
\hline Alpha & 0,05 & $\mathrm{p}$-value & 0,916 \\
\hline & & Alpha & 0,05 \\
\hline
\end{tabular}

Appendix 3-C / Box 4: Normality tests for consolidated debt including net contingent flows (Shapiro - Wilk, Anderson - Darling, Lilliefors, Jarque - Bera)

\begin{tabular}{|c|c|c|c|}
\hline \multicolumn{2}{|c|}{ Shapiro-Wilk test (Debt): } & \multicolumn{2}{|c|}{ Anderson-Darling test (Debt): } \\
\hline $\mathrm{W}$ & 1,000 & $\mathrm{~A}^{2}$ & 0,340 \\
\hline p-value & 0,285 & $\mathrm{p}$-value & 0,502 \\
\hline Alpha & 0,05 & Alpha & 0,05 \\
\hline \multicolumn{2}{|c|}{ Lilliefors test (Debt): } & \multicolumn{2}{|c|}{ Jarque-Bera test (Debt): } \\
\hline $\mathrm{D}$ & 0,005 & JB (Observed value) & 3,790 \\
\hline D (standardized) & 0,541 & JB (Critical value) & 5,991 \\
\hline p-value & 0,682 & DF & 2 \\
\hline \multirow[t]{2}{*}{ alpha } & 0,05 & $\mathrm{p}$-value & 0,150 \\
\hline & & Alpha & 0,05 \\
\hline
\end{tabular}




\section{Appendix 3-D: Monte Carlo simulation results}

Appendix 3-D / Figure 1: Monte Carlo simulation results consolidated assets

\begin{tabular}{|c|c|c|c|}
\hline $\begin{array}{c}\text { Sample } \\
\text { Number }\end{array}$ & Value & $\begin{array}{c}\text { Sample } \\
\text { Number }\end{array}$ & Value \\
\hline 1 & 12.444 .878 & 26 & 14.843 .909 \\
\hline 2 & 12.771 .306 & 27 & 15.810 .599 \\
\hline 3 & 14.745 .870 & 28 & 13.774 .339 \\
\hline 4 & 21.075 .081 & 29 & 26.097 .276 \\
\hline 5 & 14.781 .371 & 30 & 16.109 .230 \\
\hline 6 & 15.573 .755 & 31 & 9.116 .025 \\
\hline & & & \\
\hline 7 & 22.393 .942 & 32 & 16.380 .000 \\
\hline 8 & 16.645 .483 & 33 & 17.964 .724 \\
\hline 9 & 16.980 .617 & 34 & 12.137 .580 \\
\hline 10 & 18.767 .986 & 35 & 17.438 .827 \\
\hline 11 & 9.079 .938 & 36 & 16.915 .580 \\
\hline 12 & 17.104 .583 & 37 & 18.645 .855 \\
\hline 13 & 15.500 .476 & 38 & 18.038 .148 \\
\hline 14 & 15.810 .505 & 39 & 16.043 .280 \\
\hline 15 & 17.056 .503 & 40 & 19.395 .081 \\
\hline 16 & 11.225 .487 & 41 & 16.365 .489 \\
\hline 17 & 11.442 .576 & 42 & 12.643 .843 \\
\hline 18 & 15.182 .650 & 43 & 21.176 .863 \\
\hline 19 & 21.207 .073 & 44 & 17.692 .243 \\
\hline 20 & 16.619 .609 & 45 & 15.725 .823 \\
\hline 21 & 14.636 .566 & 46 & 13.327 .123 \\
\hline 22 & 16.181 .574 & 47 & 20.186 .341 \\
\hline 23 & 11.321 .882 & 48 & 10.737 .739 \\
\hline 24 & 15.324 .838 & 49 & 16.285 .338 \\
\hline 25 & 16.196 .181 & 50 & 8.715 .167 \\
\hline & & & \\
\hline
\end{tabular}

\begin{tabular}{|l|r|l|}
\hline \multicolumn{3}{|c|}{ Summary Statistics } \\
\hline Average & 15.498 .054 & \\
\hline SD & 4.466 .183 & \\
\hline Max & 31.328 .030 & \\
\hline Min & -1.089 .133 & \\
\hline
\end{tabular}

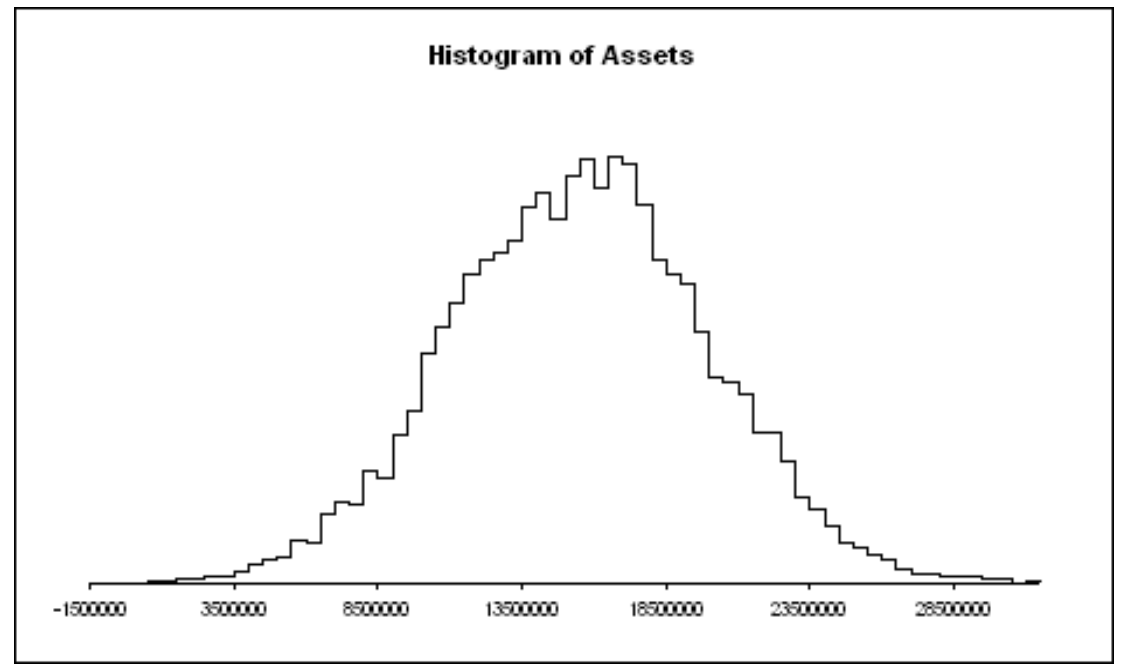


Appendix 3-D / Figure 2: Monte Carlo simulation results consolidated debt

\begin{tabular}{|c|c|c|c|}
\hline $\begin{array}{c}\text { Sample } \\
\text { Number }\end{array}$ & Value & $\begin{array}{c}\text { Sample } \\
\text { Number }\end{array}$ & Value \\
\hline 1 & 11.832 .763 & 26 & 10.829 .127 \\
\hline 2 & 15.318 .062 & 27 & 18.287 .649 \\
\hline 3 & 17.507 .689 & 28 & 12.759 .026 \\
\hline 4 & 19.802 .270 & 29 & 11.446 .495 \\
\hline 5 & 9.282 .875 & 30 & 15.047 .165 \\
\hline 6 & 15.811 .380 & 31 & 16.380 .212 \\
\hline 7 & 10.634 .338 & 32 & 12.873 .750 \\
\hline 8 & 9.567 .060 & 33 & 15.216 .297 \\
\hline & & & \\
\hline 9 & 12.100 .029 & 34 & 14.209 .074 \\
\hline 10 & 17.127 .625 & 35 & 13.323 .853 \\
\hline 11 & 12.631 .206 & 36 & 13.087 .636 \\
\hline 12 & 16.830 .209 & 37 & 13.385 .303 \\
\hline 13 & 12.280 .752 & 38 & 14.737 .292 \\
\hline & & & \\
\hline 14 & 14.218 .424 & 39 & 9.879 .244 \\
\hline 15 & 12.685 .111 & 40 & 12.116 .245 \\
\hline 16 & 15.482 .379 & 41 & 14.729 .796 \\
\hline 17 & 14.973 .854 & 42 & 15.370 .570 \\
\hline 18 & 17.870 .788 & 43 & 11.190 .180 \\
\hline 19 & 17.040 .078 & 44 & 11.124 .263 \\
\hline 20 & 12.250 .701 & 45 & 13.952 .676 \\
\hline 21 & 10.348 .717 & 46 & 16.594 .406 \\
\hline 22 & 17.763 .351 & 47 & 12.372 .369 \\
\hline 23 & 18.373 .657 & 48 & 10.426 .266 \\
\hline 24 & 15.608 .506 & 49 & 16.386 .682 \\
\hline 25 & 9.962 .902 & 50 & 12.043 .690 \\
\hline & & & \\
\hline
\end{tabular}
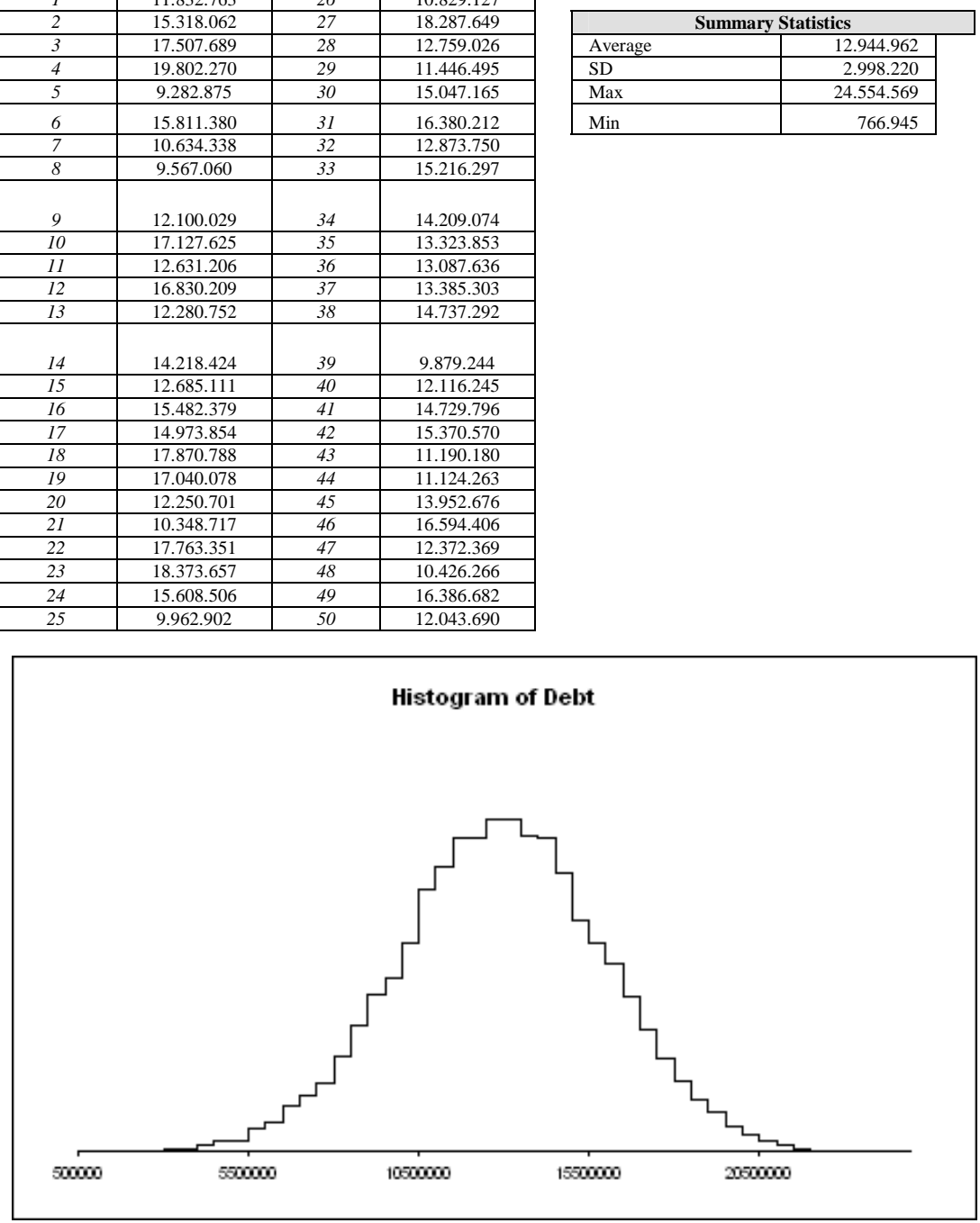
Appendix 3-D / Figure 3: Monte Carlo simulation results - guarantees

\begin{tabular}{|c|c|c|c|}
\hline $\begin{array}{l}\text { Sample } \\
\text { Number }\end{array}$ & Value & $\begin{array}{l}\text { Sample } \\
\text { Number }\end{array}$ & Value \\
\hline 1 & 4.011 & 26 & $\begin{array}{l}7.339 \\
\end{array}$ \\
\hline 2 & 10.526 & 27 & 9.785 \\
\hline 3 & 8.545 & 28 & 10.511 \\
\hline 4 & 15.425 & 29 & 6.737 \\
\hline 5 & 10.098 & 30 & -575 \\
\hline 6 & 12.949 & 31 & 8.385 \\
\hline 7 & 12.221 & 32 & 7.507 \\
\hline 8 & 9.856 & 33 & 8.673 \\
\hline 9 & 928 & 34 & 10.678 \\
\hline 10 & 15.809 & 35 & 17.128 \\
\hline 11 & 15.535 & 36 & 9.859 \\
\hline 12 & 5.406 & 37 & 8.845 \\
\hline 13 & 1.771 & 38 & 11.178 \\
\hline 14 & 7.770 & 39 & 1.841 \\
\hline 15 & 5.919 & 40 & 5.283 \\
\hline 16 & 13.079 & 41 & 16.238 \\
\hline 17 & -6.585 & 42 & 7.939 \\
\hline 18 & 12.819 & 43 & 7.275 \\
\hline 19 & 7.529 & 44 & 16.366 \\
\hline 20 & 15.810 & 45 & 10.399 \\
\hline 21 & 7.664 & 46 & 18.688 \\
\hline 22 & 1.607 & 47 & 5.404 \\
\hline 23 & 94 & 48 & 9.954 \\
\hline 24 & $\begin{array}{l}-720 \\
\end{array}$ & 49 & 7.831 \\
\hline 25 & 10.753 & 50 & 10.339 \\
\hline
\end{tabular}

\begin{tabular}{|l|r|}
\hline \multicolumn{2}{|c|}{ Summary Statistics } \\
\hline Average & 8.395 \\
\hline SD & 5.437 \\
\hline Max & 27.709 \\
\hline Min & -15.253 \\
\hline
\end{tabular}

Histogram of Guarantees

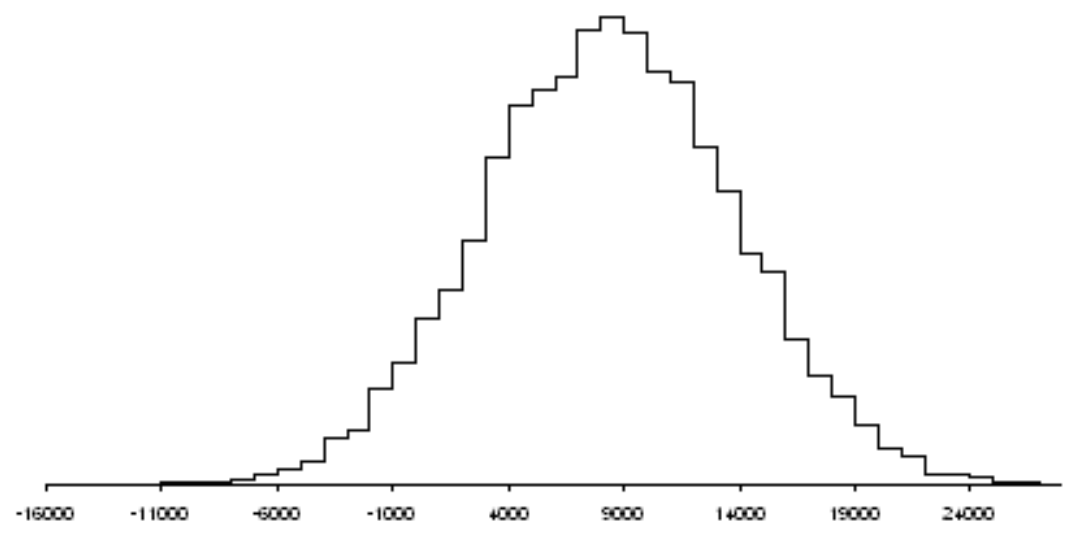


Appendix 3-D / Figure 4: Monte Carlo simulation results - expected revenues

\begin{tabular}{|c|c|c|c|}
\hline $\begin{array}{c}\text { Sample } \\
\text { Number }\end{array}$ & Value & $\begin{array}{c}\text { Sample } \\
\text { Number }\end{array}$ & Value \\
\hline 1 & 11.790 & 26 & 6.842 \\
\hline 2 & 7.115 & 27 & -827 \\
\hline 3 & 4.871 & 28 & 6.596 \\
\hline 4 & 6.956 & 29 & 9.404 \\
\hline 5 & 4.754 & 30 & 7.451 \\
\hline 6 & 6.962 & 31 & 6.857 \\
\hline 7 & 4.418 & 32 & 9.538 \\
\hline & & & \\
\hline 8 & 4.524 & 33 & 6.140 \\
\hline 9 & 3.291 & 34 & 2.482 \\
\hline 10 & -284 & 35 & 1.014 \\
\hline 11 & 4.573 & 36 & 7.401 \\
\hline 12 & -1.157 & 37 & 2.127 \\
\hline 13 & 3.842 & 38 & 4.602 \\
\hline 14 & 2.983 & 39 & 11.227 \\
\hline 15 & 6.124 & 40 & 245 \\
\hline 16 & 2.537 & 41 & 5.494 \\
\hline 17 & 2.851 & 42 & 10.650 \\
\hline 18 & -2.319 & 43 & 5.951 \\
\hline 19 & 2.169 & 44 & -780 \\
\hline 20 & 9.243 & 45 & 13.855 \\
\hline 21 & 3.094 & 46 & 6.966 \\
\hline 22 & -1.354 & 47 & 7.324 \\
\hline 23 & 8.839 & 48 & 7.579 \\
\hline 24 & 6.512 & 49 & 2.704 \\
\hline 25 & 2.696 & 50 & 2.789 \\
\hline & & & \\
\hline
\end{tabular}

\begin{tabular}{|l|r|}
\hline \multicolumn{2}{|c|}{ Summary Statistics } \\
\hline Average & 5.121 \\
\hline SD & 4.280 \\
\hline Max & 21.621 \\
\hline Min & -11.090 \\
\hline
\end{tabular}

Histogram of Expected Revenues

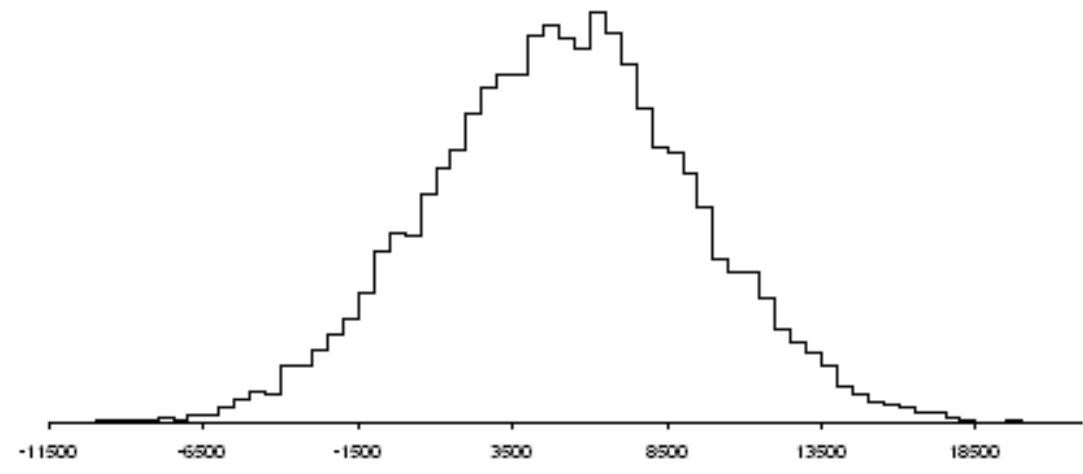


Appendix 3-E: Standard \& Poor's one-year global corporate default rates by refined rating category, 19812008

Appendix 3-E / Table 1: $S$ \& $P$ corporate default rates

\begin{tabular}{|c|c|c|c|c|c|c|c|c|c|c|c|c|c|c|c|c|c|}
\hline & AAA & $\mathrm{AA}+$ & $\mathrm{AA}$ & AA- & A+ & A & A- & BBB+ & BBB & BBB- & BB+ & BB & BB- & B+ & B & B- & $\begin{array}{l}\mathrm{CCC} \\
\text { to } \mathrm{C}\end{array}$ \\
\hline 1981 & - & - & - & - & - & - & - & - & - & - & - & - & - & - & 3,28 & - & - \\
\hline 1982 & - & - & - & - & - & 0,33 & - & - & 0,68 & - & - & 2,86 & 7,04 & 2,22 & 2,33 & 7,41 & 21,43 \\
\hline 1983 & - & - & - & - & - & - & - & - & - & 1,33 & 2,17 & - & 1,59 & 1,22 & 9,80 & 4,76 & 6,67 \\
\hline 1984 & - & - & - & - & - & - & - & - & 1,40 & - & $\frac{2,11}{-}$ & 1,64 & $\begin{array}{l}1,59 \\
1,49\end{array}$ & $\frac{1,22}{2,13}$ & $\begin{array}{l}3,00 \\
3,51\end{array}$ & $\begin{array}{l}4,10 \\
7,69\end{array}$ & $\frac{2,01}{25,00}$ \\
\hline 1985 & - & - & - & - & - & - & - & - & - & - & 1,64 & 1,49 & 1,33 & 2,59 & 13,11 & 8,00 & 15,38 \\
\hline 1986 & - & - & - & - & - & - & 0,78 & - & 0,78 & - & 1,82 & 1,18 & 1,12 & 4,65 & 12,16 & 16,67 & 23,08 \\
\hline 1987 & - & - & - & - & - & - & - & - & - & - & $\frac{1,02}{-}$ & - & 0,12 & $\begin{array}{l}, 31 \\
1,31\end{array}$ & 5,95 & 6,82 & 12,28 \\
\hline 1988 & - & - & - & - & - & - & - & - & - & - & - & - & 2,33 & 1,98 & 4,50 & 9,80 & 20,37 \\
\hline 1989 & - & - & - & - & - & - & - & 0,90 & 0,78 & - & - & - & 1,98 & 0,43 & 7,80 & 4,88 & 31,58 \\
\hline 1990 & - & - & - & - & - & - & - & 0,76 & - & 1,10 & 2,78 & 3,06 & 4,46 & 4,87 & 12,26 & 22,58 & 31,25 \\
\hline 1991 & - & - & - & - & - & - & - & $\begin{array}{l}0,703 \\
\end{array}$ & 0,74 & $\frac{1,10}{-}$ & $\begin{array}{l}3,160 \\
3,70\end{array}$ & $\begin{array}{l}1,111 \\
\end{array}$ & $\begin{array}{l}\frac{4,40}{1,05} \\
\end{array}$ & $\begin{array}{l}, 61 \\
8,72\end{array}$ & 16,25 & 32,43 & $\begin{array}{l}31,25 \\
33,87\end{array}$ \\
\hline 1992 & - & - & - & - & - & - & - & - & - & - & - & - & - & 0,72 & 14,93 & 20,83 & 30,19 \\
\hline 1993 & - & - & - & - & - & - & - & - & - & - & - & 1,92 & - & 1,30 & 5,88 & 4,17 & 13,33 \\
\hline 1994 & - & - & - & - & 0,45 & - & - & - & - & - & - & 0,86 & - & 1,83 & 6,58 & 3,23 & 16,67 \\
\hline 1995 & - & - & - & - & - & - & - & - & - & 0,63 & - & 1,55 & 1,11 & 2,76 & 8,00 & $\begin{array}{l}7,69 \\
\end{array}$ & 28,00 \\
\hline 1996 & - & - & - & - & - & - & - & - & - & - & 0,86 & 0,65 & 0,55 & 2,33 & 3,74 & 3,92 & 4,17 \\
\hline 1997 & - & - & - & - & - & - & - & 0,36 & 0,34 & - & - & - & 0,41 & 0,72 & 5,19 & 14,58 & 12,00 \\
\hline 1998 & - & - & - & - & - & - & - & - & $\begin{array}{l}0,54 \\
\end{array}$ & 0,70 & 1,29 & 1,06 & $\frac{0,41}{0,72}$ & 2,57 & $\frac{1,1}{7,47}$ & 9,46 & 42,86 \\
\hline 1999 & - & - & - & 0,36 & - & 0,24 & 0,27 & - & 0,28 & 0,30 & 0,54 & 1,33 & 0,90 & 4,20 & 10,55 & 15,45 & 32,35 \\
\hline 2000 & - & - & - & $\frac{1,30}{-}$ & - & $\begin{array}{l}0,24 \\
0,24\end{array}$ & $\begin{array}{l}0,27 \\
0,56\end{array}$ & - & $\begin{array}{l}0,20 \\
0,26\end{array}$ & $\begin{array}{l}0,50 \\
0,88\end{array}$ & $\frac{0,34}{-}$ & $\begin{array}{l}0,50 \\
0,80\end{array}$ & $\frac{0,80}{2,29}$ & $\begin{array}{l}\frac{4,20}{5,60} \\
\end{array}$ & 10,66 & $\frac{10,43}{11,50}$ & $\begin{array}{l}32,35 \\
34,12\end{array}$ \\
\hline 2001 & - & - & - & - & 0,57 & $\begin{array}{l}0,49 \\
\end{array}$ & - & 0,24 & 0,48 & 0,27 & 0,49 & $\begin{array}{l}1,19 \\
\end{array}$ & 6,27 & 5,94 & 15,74 & 23,31 & 44,55 \\
\hline$\frac{2001}{2002}$ & - & - & - & - & $\frac{1}{-}$ & $\frac{0,49}{-}$ & - & $\frac{0,24}{1,11}$ & $\frac{0,40}{0,65}$ & $\frac{d, 21}{1,31}$ & $\frac{0,49}{1,50}$ & $\frac{T^{\prime}, 17}{1,74}$ & $\frac{0,21}{4,62}$ & $\frac{3,94}{3,69}$ & 9,63 & $\begin{array}{l}3,5,1 \\
19,53\end{array}$ & $\begin{array}{l}4+, 3,12 \\
44,12\end{array}$ \\
\hline 2003 & - & - & - & - & - & - & - & - & $\begin{array}{l}0,19 \\
\end{array}$ & 0,52 & 0,48 & 0,94 & $\begin{array}{l}, 0,27 \\
\end{array}$ & 1,70 & 5,16 & 9,23 & 33,13 \\
\hline 2004 & - & - & - & - & - & 0,23 & - & - & - & - & - & 0,64 & 0,76 & 0,46 & 2,68 & 2,82 & 15,11 \\
\hline 2005 & - & - & - & - & - & - & - & - & 0,17 & - & 0,36 & - & 0,25 & 0,78 & 2,59 & $\frac{2,02}{2,98}$ & 8,87 \\
\hline 2006 & - & - & - & - & - & - & - & - & - & - & 0,36 & - & 0,48 & 0,54 & 0,78 & 1,58 & 13,08 \\
\hline 2007 & - & - & - & - & - & - & - & - & - & - & $\frac{0,00}{-}$ & 0,30 & $\frac{0,40}{0,23}$ & $\frac{0,34}{0,19}$ & $\frac{10}{-}$ & $\frac{1,50}{0,88}$ & $\frac{15,06}{14,81}$ \\
\hline 2008 & $\begin{array}{llll}- & \\
\end{array}$ & - & 0,43 & 0,40 & 0,31 & 0,21 & 0,58 & 0,18 & 0,59 & 0,71 & 1,14 & 0,63 & 0,63 & 2,97 & 3,29 & 7,02 & 26,53 \\
\hline Mean & - & - & $\frac{1,45}{0,02}$ & $\frac{0,40}{0,03}$ & $\frac{0,31}{0,05}$ & $\frac{0,21}{0,06}$ & $\begin{array}{l}0,008 \\
0,08\end{array}$ & $\frac{0,10}{0,16}$ & $\frac{0,57}{0,28}$ & $\frac{0,71}{0,28}$ & $\frac{1,14}{0,68}$ & $\frac{0,03}{0,89}$ & $\begin{array}{l}, 03 \\
1,53\end{array}$ & $\frac{2,97}{2,44}$ & $\frac{7,29}{7,28}$ & $\begin{array}{l}, 02 \\
9,97\end{array}$ & $\frac{20,35}{22,67}$ \\
\hline Median & - & - & - & - & - & - & - & - & $0,0,08$ & - & 0,18 & 0,83 & 0,86 & 2,06 & 6,27 & 7,69 & 22,25 \\
\hline Minimum & - & - & - & - & - & - & - & - & - & - & - & - & - & - & & - & \\
\hline Maximum & - & - & 0,43 & 0,40 & 0,57 & 0,49 & 0,78 & 1,11 & 1,40 & 1,33 & 3,70 & 3,06 & 7,04 & 8,72 & 16,25 & 32,43 & 44,55 \\
\hline Standard & - & - & 0,08 & 0,10 & 0,14 & 0,13 & 0,20 & 0,32 & 0,36 & 0,43 & 0,96 & 0,84 & 1,83 & 2,02 & 4,51 & 7,82 & 11,93 \\
\hline
\end{tabular}




\section{Appendix 3-F: Credit Default Swap (CDS) definitions and valuation principles}

Credit Default Swaps (CDSs) are the most popular type of credit derivatives. Their payoff depends on the creditworthiness of particular companies or countries. A financial actor may use them either to reduce its credit risk exposure by buying protection or to diversify credit risk. More specifically, a credit default swap is a contract that provides insurance against the risk of a default by a specific reference entity. The buyer of the insurance obtains the right to sell bonds at their face value issued by the reference entity in case the latter defaults, whereas the seller agrees to buy the bonds. The purchase of the swap is in the form of periodic payments by the buyer to the seller until the reference entity defaults. The contract, in the case of default, may require either a physical settlement, where the buyer has the right to sell the bonds at face value to the seller or a cash settlement, where a mid-market value of the cheapest-to-deliver bond is calculated by dealers for a predestinated number of days after the default. The payoff is usually determined by the difference between the face value of the bond and its value after the default. Credit default swaps can be valued from the default probabilities estimates, which should be risk-neutral. By estimating the probability of default and by discounting at the risk free interest rate, we can calculate the present values of the expected payments, the expected payoff and the expected accrual payment in the event of default.

For the valuation of the credit default swaps, we apply the typical assumptions of the independence of default probabilities, interest rates and recovery rates but also to adjust the relevant CDS definitions to the situation of a PPP. In this case, the government can reduce its risk exposure by buying insurance from a financial intermediary. The protection is against the possibility of default of the reference entity, the private agent in the partnership. The first step is to calculate the risk-neutral probability that the reference entity will default at different future times. The rates on the bonds 
issued by the private partners, with the LIBOR rates as a benchmark, can serve as estimators for the probability of default. The assumption is that the only reason that a corporate bond sells for less than a typical LIBOR based (or treasury) bond is the possibility of default. Then for bonds with the same cash flows and the same value:

Value of a LIBOR based Bond - Value of Corporate Bond = $=$ Present Value of Cost of Defaults.

Using the above relationship we calculate present values of the cost of defaults from a series of corporate bonds issued by the private partners. Then, assuming a specific recovery rate, we can calculate the probability of default of the private partners at different time periods. We use bonds that were issued by the partner consortium for every PPP project in Route 5. Table 1 shows the consortiums and the partners for each PPP project, as well as the Standard and Poor's credit rating for each bond that was issued by each consortium or partner. The payoff from a credit default swap in the case of default at time $t$, is the face value of the corporate bond minus its market value just after time t. Therefore, the payoff from a typical credit default swap is (Hull, 2006): $\mathrm{L}-\mathrm{RL}[1+\mathrm{A}(\mathrm{t})]$, where $\mathrm{L}$ is the total par value of the bond that can be sold (the notional principal), $\mathrm{R}$ is the recovery rate and $\mathrm{A}(\mathrm{t})$ is the accrued interest on the bond at time $t$ as a percent of its face value. In table 1 we can see the S\&P credit ratings for the bonds issued to cover the greatest part of the financing for Route 5 PPP projects. The ratings vary from AA- to BB-. ${ }^{122}$ In table 2 we calculate the default and survival probabilities.

\footnotetext{
122 The credit rating definitions by the agency is as follows (Standard and Poor's, 2009b, page 10):

- "AA: An obligor rated 'AA' has very strong capacity to meet its financial commitments. It differs from the highest-rated obligors only to a small degree. An obligor rated 'brAA' has a strong capacity to meet its financial commitments relative to that of other Brazilian obligors."

- "BBB: An obligor rated 'BBB' has adequate capacity to meet its financial commitments. However, adverse economic conditions or changing circumstances are more likely to lead to a weakened capacity of the obligor to meet its financial commitments."
} 
Appendix 3-F / Table 1: Infrastructure Bond Ratings, Route 5 projects

\begin{tabular}{|c|c|c|c|}
\hline Project & Consortium name & Partners & $\begin{array}{c}\text { S\&P } \\
\text { Rating }\end{array}$ \\
\hline Talca-Chillan & $\begin{array}{c}\text { Ruta } 5 \text { Tramo Talca } \\
\text { Chillan S.A. }\end{array}$ & $\begin{array}{l}\text { Cruz Blanca (Chile), } \\
\text { Ferrovial (Spain) }\end{array}$ & BBB- \\
\hline Santiago-Los Vilos & Tribasa - Inela S.A. & $\begin{array}{c}\text { Tribasa Conosur Inela } \\
\text { (Mexico) }\end{array}$ & $\mathrm{BB}^{-123}$ \\
\hline Los Vilos - La Serena & Sacyr Chile S.A. & Sacyr (Spain) & $\mathrm{BB}+$ \\
\hline Chillan-Collipulli & Tribasa Conosur S.A. & Tribasa (Mexico) & BB- \\
\hline Temuco-Rio Bueno & Ecovias 5 S.A. & $\begin{array}{l}\text { Ferrovial (Spain), Delta } \\
\text { S.A. (Chile), CB } \\
\text { Infraestructura (Chile) } \\
\end{array}$ & brAA- ${ }^{124}$ \\
\hline $\begin{array}{c}\text { Rio Bueno-Puerto } \\
\text { Montt }\end{array}$ & Sacyr Chile S.A. & Sacyr (Spain) & $\mathrm{BB}+$ \\
\hline Collipulli-Temuco & Favias S.A. & $\begin{array}{c}\text { Ferrovial (Spain), Agromar } \\
\text { (Spain) }\end{array}$ & BBB- ${ }^{125}$ \\
\hline Santiago-Talca & $\begin{array}{c}\text { Autopistas del Maipo } \\
\text { S.A. }\end{array}$ & $\begin{array}{c}\text { Ferrovial (Spain), Agroman } \\
\text { (Spain), Banco Santander } \\
\text { (Spain) }\end{array}$ & BBB- \\
\hline
\end{tabular}

2. Standard \& Poor's, 2009a.

Appendix 3-F / Table 2: Unconditional default probabilities and survival probabilities, Route 5 projects, years 1998-2007

\begin{tabular}{|c|c|c|c|c|c|c|c|c|}
\hline \multirow{2}{*}{ Year } & \multicolumn{2}{|c|}{ Talca - Chillan } & \multicolumn{2}{c|}{ Santiago - Los Vilos } & \multicolumn{2}{c|}{ La Serena - Los Vilos } & \multicolumn{2}{c|}{ Chillan - Collipulli } \\
\cline { 2 - 9 } & $\begin{array}{c}\text { Default } \\
\text { Probability }\end{array}$ & $\begin{array}{c}\text { Survival } \\
\text { Probability }\end{array}$ & $\begin{array}{c}\text { Default } \\
\text { Probability }\end{array}$ & $\begin{array}{c}\text { Survival } \\
\text { Probability }\end{array}$ & $\begin{array}{c}\text { Default } \\
\text { Probability }\end{array}$ & $\begin{array}{c}\text { Survival } \\
\text { Probability }\end{array}$ & $\begin{array}{c}\text { Default } \\
\text { Probability }\end{array}$ & $\begin{array}{c}\text { Survival } \\
\text { Probability }\end{array}$ \\
\hline $\mathbf{1 9 9 8}$ & 0,0028 & 0,9972 & - & - & - & - & - & - \\
\hline $\mathbf{1 9 9 9}$ & 0,0028 & 0,9944 & 0,0153 & 0,9847 & - & - & - & - \\
\hline $\mathbf{2 0 0 0}$ & 0,0028 & 0,9916 & 0,0151 & 0,9696 & 0,0068 & 0,9932 & - & - \\
\hline $\mathbf{2 0 0 1}$ & 0,0028 & 0,9888 & 0,0148 & 0,9548 & 0,0068 & 0,9864 & 0,0153 & 0,9847 \\
\hline $\mathbf{2 0 0 2}$ & 0,0028 & 0,9861 & 0,0146 & 0,9402 & 0,0067 & 0,9797 & 0,0151 & 0,9696 \\
\hline $\mathbf{2 0 0 3}$ & 0,0028 & 0,9833 & 0,0144 & 0,9258 & 0,0067 & 0,9731 & 0,0148 & 0,9548 \\
\hline $\mathbf{2 0 0 4}$ & 0,0028 & 0,9806 & 0,0142 & 0,9116 & 0,0066 & 0,9665 & 0,0146 & 0,9402 \\
\hline $\mathbf{2 0 0 5}$ & 0,0027 & 0,9778 & 0,0139 & 0,8977 & 0,0066 & 0,9599 & 0,0144 & 0,9258 \\
\hline $\mathbf{2 0 0 6}$ & 0,0027 & 0,9751 & 0,0137 & 0,8840 & 0,0065 & 0,9534 & 0,0142 & 0,9116 \\
\hline $\mathbf{2 0 0 7}$ & 0,0027 & 0,9724 & 0,0135 & 0,8704 & 0,0065 & 0,9469 & 0,0139 & 0,8977 \\
\hline
\end{tabular}

- "BB: An obligor rated 'BB' is less vulnerable in the near term than other lower-rated obligors. However, it faces major ongoing uncertainties and exposure to adverse business, financial, or economic conditions which could lead to the obligor's inadequate capacity to meet its financial commitments."

${ }^{123}$ S\&P removed the credit rating for Tribasa after failing to supply the agency with sufficient information.

${ }^{124}$ S\&P Brazil national scale.

125 The rating was withdrawn after company's request. 


\begin{tabular}{|c|c|c|c|c|c|c|c|c|}
\hline \multirow{2}{*}{ Year } & \multicolumn{2}{|c|}{ Temuco - Rio Bueno } & \multicolumn{2}{c|}{ Rio Bueno - Puerto Montt } & \multicolumn{2}{c|}{ Collipulli - Temuco } & \multicolumn{2}{c|}{ Santiago - Talca } \\
\cline { 2 - 9 } & $\begin{array}{c}\text { Default } \\
\text { Probability }\end{array}$ & $\begin{array}{c}\text { Survival } \\
\text { Probability }\end{array}$ & $\begin{array}{c}\text { Default } \\
\text { Probability }\end{array}$ & $\begin{array}{c}\text { Survival } \\
\text { Probability }\end{array}$ & $\begin{array}{c}\text { Default } \\
\text { Probability }\end{array}$ & $\begin{array}{c}\text { Survival } \\
\text { Probability }\end{array}$ & $\begin{array}{c}\text { Default } \\
\text { Probability }\end{array}$ & $\begin{array}{c}\text { Survival } \\
\text { Probability }\end{array}$ \\
\hline $\mathbf{1 9 9 8}$ & - & - & - & - & - & - & - & - \\
\hline $\mathbf{1 9 9 9}$ & - & - & - & - & - & - & - & - \\
\hline $\mathbf{2 0 0 0}$ & - & - & - & - & - & - & - & - \\
\hline $\mathbf{2 0 0 1}$ & 0,0003 & 0,9997 & 0,0068 & 0,9932 & - & - & - & - \\
\hline $\mathbf{2 0 0 2}$ & 0,0003 & 0,9994 & 0,0068 & 0,9864 & 0,0028 & 0,9972 & 0,0028 & 0,9972 \\
\hline $\mathbf{2 0 0 3}$ & 0,0003 & 0,9991 & 0,0067 & 0,9797 & 0,0028 & 0,9944 & 0,0028 & 0,9944 \\
\hline $\mathbf{2 0 0 4}$ & 0,0003 & 0,9988 & 0,0067 & 0,9731 & 0,0028 & 0,9916 & 0,0028 & 0,9916 \\
\hline $\mathbf{2 0 0 5}$ & 0,0003 & 0,9985 & 0,0066 & 0,9665 & 0,0028 & 0,9888 & 0,0028 & 0,9888 \\
\hline $\mathbf{2 0 0 6}$ & 0,0003 & 0,9982 & 0,0066 & 0,9599 & 0,0028 & 0,9861 & 0,0028 & 0,9861 \\
\hline $\mathbf{2 0 0 7}$ & 0,0003 & 0,9979 & 0,0065 & 0,9534 & 0,0028 & 0,9833 & 0,0028 & 0,9833 \\
\hline \multicolumn{7}{|c|}{ Sources: Standard \& Poor's, $2009 a$} \\
\end{tabular}

An approach to calculate the risk-neutral default probabilities would be to use credit default swap quotes. More specifically, the mid-market CDS spread can give an implied default probability per year; then through discounting we are able to calculate the present values of the expected accrual payment and the expected payoff for the credit default swap. But since we are interested in valuing the CDS itself and not the default probability, we use bond ratings to estimate the default probabilities. We also need to assume a recovery rate for our calculations. However, the value of the credit default swap is not very sensitive to the recovery rate, if we use the same recovery rate for both estimating the risk-neutral default probabilities and valuing the credit default swap. This is because the implied probabilities of default are approximately proportional to $1 /(1-\mathrm{R})$, where $\mathrm{R}$ is the recovery rate, while the payoffs from a credit default swap are proportional to $1-\mathrm{R}$ (Hull, 2006). Respectively, we assume a recovery rate of $40 \%$ and a discount (LIBOR average) rate of $4,91 \%$. Finally, we assume that default always happens halfway through the year and that payments on the credit default swaps are made once a year, at the end of each year.

After the above assumptions, we can carry on with the valuation of a credit default swap without counterparty default risk. We also assume a $\$ 1$ notional principal and, as mentioned before, that default probabilities, interest rates, and recovery rates are mutually independent. We define (after Hull, 2006): 
T: Life of credit default swap

$\mathrm{p}_{\mathrm{i}}$ : Risk-neutral default probability density at time $t_{\mathrm{i}}$

$\mathrm{R}$ : Expected recovery rate on the reference obligation in a risk-neutral world (assumed to be independent of the time of default)

$\mathrm{u}(\mathrm{t})$ : Present value of payments at the rate of $\$ 1$ per year on payment dates between time zero and time $t$ ( $t$ measured in years)

$\mathrm{e}(\mathrm{t})$ : Present value of a payment at time $\mathrm{t}$ equal to $\mathrm{t}-\mathrm{t}^{*}$ dollars, where $t^{*}$ is the payment date immediately preceding time $\mathrm{t}$

$v(t)$ : Present value of $\$ 1$ received at time $t$

w: Total payments per year made by credit default swap buyers per dollar

$A(t)$ : Accrued interest on the reference obligation at time $t$ as a percent of face value.

Assuming a notional principal of $\$ 1$, the payoff of the credit default swap is:

$$
1-\mathrm{R}-\mathrm{A}(\mathrm{t}) \mathrm{R}
$$

The payments last until the private partner defaults, or until time $\mathrm{T}$, whichever is the soonest. The present value of the payments is:

$$
w \sum_{i=1}^{n}\left[u\left(t_{i}\right)+e\left(t_{i}\right)\right] p_{i}+w p u(T)
$$

And the present value of the payoff from the credit default swap is:

$$
\sum_{i=1}^{n}\left[1-\mathrm{R}-\mathrm{A}\left(\mathrm{t}_{\mathrm{i}}\right) \mathrm{R}\right] p_{i} v\left(t_{i}\right)
$$

Finally, the value of the credit default swap to the government is the present value of the expected payoff minus the present value of the payments made by the government:

$$
\sum_{i=1}^{n}\left[1-\mathrm{R}-\mathrm{A}\left(\mathrm{t}_{\mathrm{i}}\right) \mathrm{R}\right] p_{i} v\left(t_{i}\right)-w \sum_{i=1}^{n}\left[u\left(t_{i}\right)+e\left(t_{i}\right)\right] p_{i}+w p u(T)
$$

The first step is to calculate the default probabilities from bond ratings. We choose this approach, since the only reason a corporate bond will sell for less than a similar riskfree bond is the possibility of default. As already mentioned, 
we assume that the discount rate for all maturities is $4,91 \%$, a recovery rate of $40 \%$ and that default occurs halfway through the years of the lifetime of the bond, which is analogous with lifetime of the PPP project. Initially, the expected loss of default over the lifetime of a corporate bond has to be calculated. It can be computed by considering an annual rate coupon, an annual yield on the corporate bond and an assumption for the risk-free bond. With these rates we can calculate an expected loss of default, which will be the difference between the price of the corporate bond and the price of the risk-free bond. Eventually, we are in a position to calculate a risk-free bond value, the loss given default and the present value of the expected default in default probability terms for all the years of the PPP contract. Consequently, we can obtain a value of the default probability for each year, setting the total present value of the expected loss in default probability terms equal to the expected loss of default. ${ }^{126} \mathrm{We}$ have incorporated this process to the Standard and Poor's ratings for the default probabilities calculations as it was presented previously. This can be extended to calculate default probabilities for credit events that occur more frequently than halfway each year.

For the valuation of a CDS with counterparty default, we maintain the definitions above. Further on we define (after Hull, 2006):

$\theta(\mathrm{t}) \Delta \mathrm{t}$ : Risk-neutral probability of default by reference entity between times $t$ and $t+\Delta t$ and no earlier default by counterparty,

$\varphi(\mathrm{t}) \Delta \mathrm{t}$ : Risk-neutral probability of default by counterparty between times $t$ and $t+\Delta t$ and no earlier default by reference entity.

The credit default swap payments terminate if either party defaults. Respectively there are two cases: the reference entity (private partner) defaults at time $t$ with no earlier default by the counterparty (government) or the counterparty (government) defaults at time $t$ with no earlier default by the

\footnotetext{
${ }^{126}$ This expected loss of default is the difference between the price of the corporate bond and the price of the risk free bond.
} 
reference entity (private partner). In the first case, there is a final accrual payment for the credit default swap and the present value of all payments made is $\mathrm{w}[\mathrm{u}(\mathrm{t})+\mathrm{e}(\mathrm{t})]$. In the latter case, the present value of the payments is $w u(t)$. Finally, there is the possibility that none of the parties default and the swap expires at maturity. In this case, the present value of the payment is $\mathrm{wu}(\mathrm{T})$.

Assuming a notional principal of $\$ 1$, the payoff of the credit default swap is $1-\mathrm{R}-\mathrm{A}(\mathrm{t}) \mathrm{R}$. The final step is to calculate the present value of the expected payoff and the present value of the credit default swap payments. Their differential is the value of the credit default swap for the government. The present value of the CDS payments for a swap with counterparty default risk is:

$$
w \sum_{i=1}^{n}\left[\theta\left(t_{i}\right) u\left(t_{i}\right)+\theta\left(t_{i}\right) e\left(t_{i}\right)+\phi\left(t_{i}\right) u\left(t_{i}\right)\right]+w p u(T)
$$

and the present value of the expected payoff from the credit default swap is:

$$
\sum_{i=1}^{n}\left[1-\mathrm{R}-\mathrm{A}\left(\mathrm{t}_{\mathrm{i}}\right) \mathrm{R}\right] \theta\left(t_{i}\right) u\left(t_{i}\right)
$$

Finally, the value of the credit default swap to the government is the present value of the expected payoff minus the present value of the payments made by the government:

$$
\begin{gathered}
\sum_{i=1}^{n}\left[1-\mathrm{R}-\mathrm{A}\left(\mathrm{t}_{\mathrm{i}}\right) \mathrm{R}\right] \theta\left(t_{i}\right) u\left(t_{i}\right)- \\
w \sum_{i=1}^{n}\left[\theta\left(t_{i}\right) u\left(t_{i}\right)+\theta\left(t_{i}\right) e\left(t_{i}\right)+\phi\left(t_{i}\right) u\left(t_{i}\right)\right]+w p u(T)
\end{gathered}
$$

For the calculation of CDS payments with counterparty default, we use the Chilean government credit ratings. According to the agency's rating in December 2008, the long term foreign currency debt was rated as A+. Following this rating we calculate the unconditional default probabilities and survival probabilities for Chile as we did previously for the private actors for each project. The average default probability for an $\mathrm{A}+$ rating is $0,05 \%$. Again, if the probability of default for the first year is $\mathrm{PD}_{1}$, then the probability of survival for that year is $1-\mathrm{PD}_{1}$, the probability of 
default for the second year is $\mathrm{PD}_{2}=\mathrm{PD}_{1} *\left(1-\mathrm{PD}_{1}\right)$ and the probability of survival is $1-\mathrm{PD}_{2}$ and so on. Default and survival probabilities are shown in table 3 for the whole period 1998 through 2007, when guarantees for PPP projects begun to occur.

Appendix 3-F / Table 3: Unconditional default probabilities and survival probabilities, Chilean government

\begin{tabular}{|c|c|c|}
\hline \multirow{2}{*}{ Year } & \multicolumn{2}{|c|}{ Chile } \\
\cline { 2 - 3 } & Default Probability & Survival Probability \\
\hline $\mathbf{1 9 9 8}$ & 0,0005 & 0,9995 \\
\hline $\mathbf{1 9 9 9}$ & 0,0005 & 0,9990 \\
\hline $\mathbf{2 0 0 0}$ & 0,0005 & 0,9985 \\
\hline $\mathbf{2 0 0 1}$ & 0,0005 & 0,9980 \\
\hline $\mathbf{2 0 0 2}$ & 0,0005 & 0,9975 \\
\hline $\mathbf{2 0 0 3}$ & 0,0005 & 0,9970 \\
\hline $\mathbf{2 0 0 4}$ & 0,0005 & 0,9965 \\
\hline $\mathbf{2 0 0 5}$ & 0,0005 & 0,9960 \\
\hline $\mathbf{2 0 0 6}$ & 0,0005 & 0,9955 \\
\hline $\mathbf{2 0 0 7}$ & 0,0005 & 0,9950 \\
\hline Sources: & 1. Ministry of Finance, Standard \& Poor's, 2009a \\
\hline
\end{tabular}




\section{Appendix 3-G: Detailed calculations of expected CDS payments, CDS accruals and CDS payoffs}

Appendix 3-G / Table 1: Present value of expected CDS payments, Route 5 projects, no counterparty default
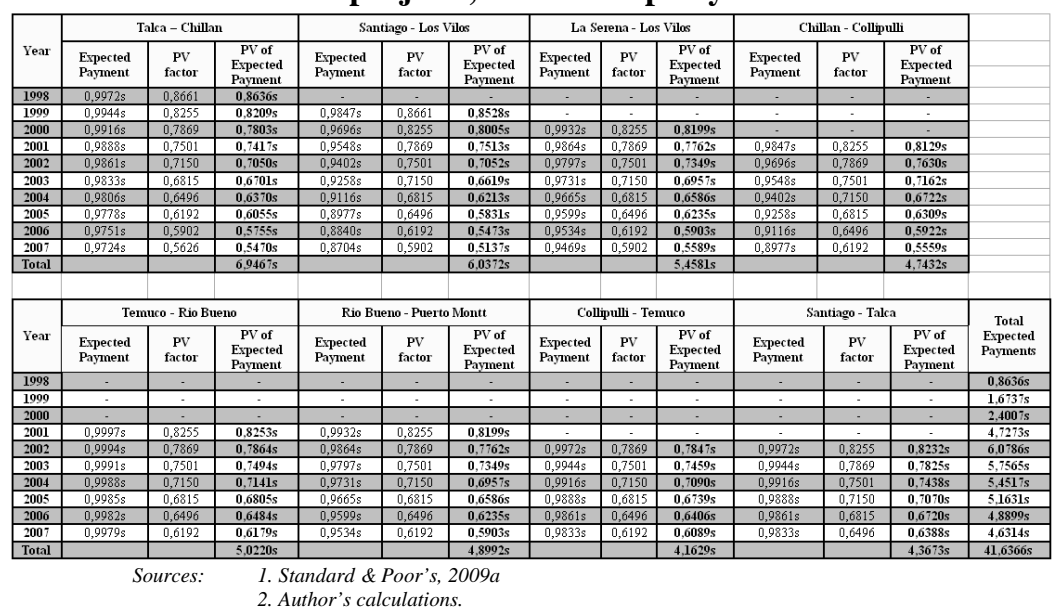

Description: Table 1 consolidates all calculations of the expected CDS payments, assuming a notional principal of $\mathrm{CH} \$ 1$ and that payments are made once at the end of each year and at the rate of $s$ per annum. The expected payment is the annual payment rate times the probability of survival, or $s^{*}(1-\mathrm{PD})$. The table shows all the expected annual payments for every project. For example, there is a $98,33 \%$ probability that the private partner will not default in year 2007 for the Santiago - Talca project. The discount factor, using year 1998 when the investment initiated as a base year, is $1 /(1+0,0491)^{9}=0,6496$. This gives us a discounted expected CDS payment of $0,6496 * 0,9833 \mathrm{~s}=0,6388 \mathrm{~s}$ for the specific year and project. 
Appendix 3-G / Table 2: Present value of accrual CDS payments, Route 5 projects, no counterparty default
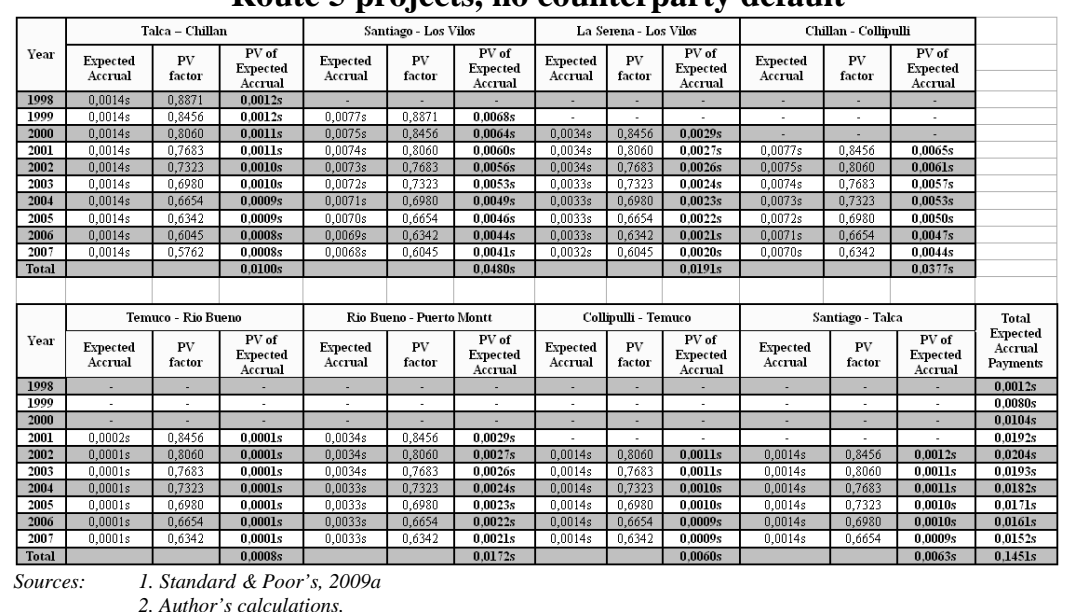

Description: In table 2 we calculate the accrual payments in the case of default by the private partner. Since we consider that default could occur only halfway through the year, then accrual payments occur halfway through the year as well. This means that an accrual equals $0,5 \mathrm{~s}$ and that we should change our PV factors to accommodate payments halfway through the year. Respectively the accrual payment is half the probability of default times the payment rate per annum. For example, for year 2007 the Santiago - Talca project accrual payment is calculated as follows: the probability of default for this year and for this project is 0,0028 and the accrual payment is $0,5 * 0,0028 \mathrm{~s}=0,0014 \mathrm{~s}$. The discount factor is $1 /(1+0,0491)^{8,5}=0,6654$, so the present value of the accrual payment is $0,6654 * 0,0014 \mathrm{~s}=0,0009 \mathrm{~s}$. 
Appendix 3-G / Table 3: Present value of expected CDS payoffs, Route 5 projects, no counterparty default

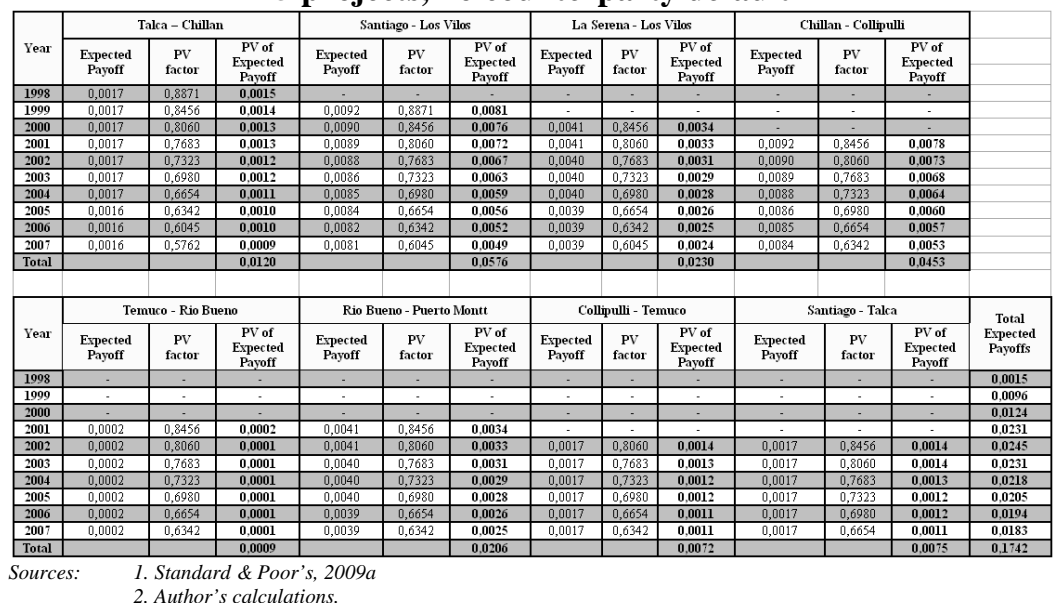

Description: In table 3 we calculate the expected payoff calculations towards the government in the case that the private partner defaults. Since default is assumed to happen halfway through the year, we use the same discount factors as in the previous case of the accrual payments. Regarding $40 \%$ as a recovery rate (R), we calculate the expected payoff by multiplying the probability of default with $1-\mathrm{R}$; so expected payoff $=$ PD*(1-R). For example, for year 2007 in the Santiago-Talca project the expected payoff is $0,0028 *(1-0,4)=0,0017$. Then, its present value is $0,0017 * 1 /(1+0,0491)^{8,5}=0,0011$. 
Appendix 3-G / Table 4: Present value of expected CDS payments, Route 5 projects, counterparty default
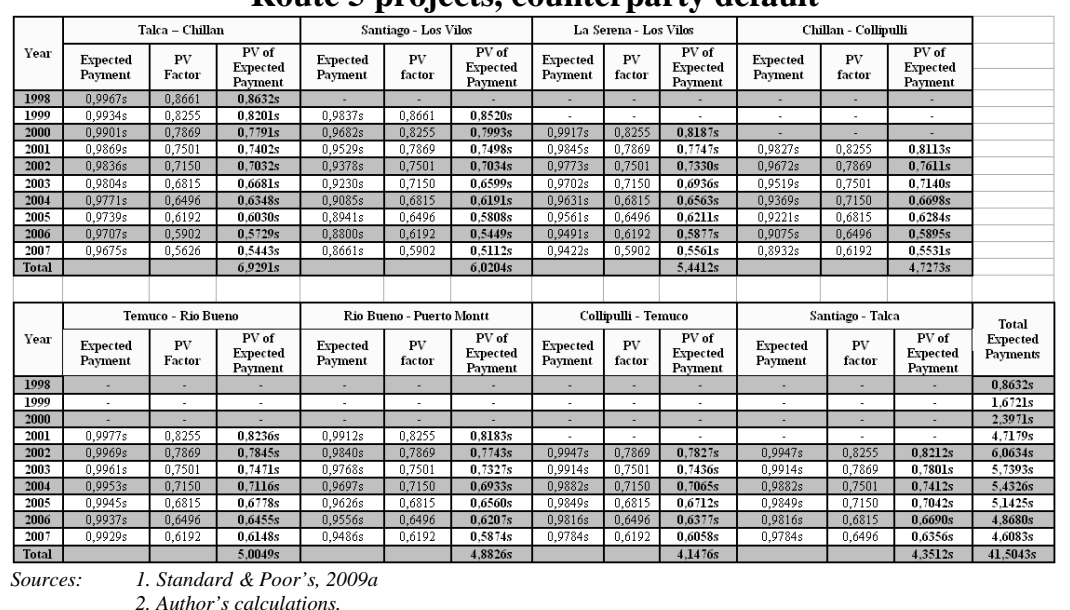

Description: In table 4 we calculate the expected payment calculations with counterparty default risk. For example, the Santiago-Talca private partner has a 0,9833 probability of survival for the year 2007, while the Chilean government has a 0,9950 probability of survival for the same year. So, the expected CDS payment is $0,9784 \mathrm{~s}$, where $\mathrm{s}$ is the annual payment rate. The discount factor is $1 /(1+0,0491)^{9}=0,6496$, so the present value of this expected payment is $0,9784 \mathrm{~s} * 0,6496=0,6356 \mathrm{~s}$. 


\section{Appendix 4-A: Credit protection and securitized transactions}

\section{4-A.1 Cross-country and market spillovers}

The negative externalities of the crisis, apart from the cross-country spillovers, were also spread through markets. The growing uncertainty brought about by such bad news had a direct effect on securitization markets. After continuous loan defaults, what followed were losses in securitization tranches and, respectively, write-downs, liquidations and huge drops in the tranches' values. ${ }^{127}$ The basic aim of securitization was actually turned into a boomerang; instead of the off-balance sheet protection that it was supposed to provide, it expanded the risk exposures that were tagged along with the tranches and thus negatively affected the financial assets on the balance sheet. This was expressed via numerous write-downs of financial assets.

Ultimately, liquidity was the main concern of financial institutions who, in their attempt to reach short-term financing, begun liquidating their financial assets at very high discounts so as to circumvent over-indebtedness. This effect was contagiously spread from the financial market to the credit market, where credit spreads widened and the failure to recognize the counterparty risk in credit protection contracts such as credit default swaps (CDS), led to large un-hedged positions following a counterparty's default. The need for refinancing was twofold: to cover losses that followed securitization tranches and to achieve market credit protection. At the same time, interbank supply of loans was decreasing since banks were reluctant to lend among each other. The increasing need (and at the same time lack of) liquidity together with the diminishing "trust" in the banking system, created a disequilibrium in the overall financial system, thereby increasing systemic risk.

\footnotetext{
${ }^{127}$ Basically, because of greater uncertainty concerning the risk profile of these tranches.
} 


\section{4-A.2 Beyond banks}

Apart from the housing bubble, there is strong evidence that the growth of securitization itself played an important role in the crisis. From the moment that the financial system expanded beyond the traditional banking sector and lenders and borrowers exchanged funds using various financial intermediaries apart from banks, the process of intermediation was transferred from the banking sector to the securities markets. A key aspect is that through securitization, the credit risk was relocated from the bank's balance sheet to pools with many different debt instruments, including mortgages (Gorton, 2007). A specific mortgage pool can be split into tranches that allow investors to take specific positions in terms of risk, depending on whether they are risk lovers or risk averters. Senior tranches have a very high credit rating with defaults close to zero, mezzanine tranches feature middle default rates, while equity tranches are characterized by very high default probabilities and at the same time very high yields. The complexity of the valuation of such mortgage backed securities makes it very hard to assess the solvency of each firm, creating a serious lack of information for the actors in the financial market. This important information asymmetry that arose in the securities market, combined with the lack of a concrete regulatory framework, resulted in a situation where, in the name of risk spreading, each bank was no longer interested in the borrowers' ability to repay, since the default risk had been transferred off the balance sheet into securitized financial products.

Information asymmetries, as prominently portrayed by Gorton (2007), and moral hazard, as described above, are the two most important determinants of the market failure. The development of even more complex forms of securitization and financial products enhanced the quicker allocation of the risk to other secondary markets and risk exposure assessments became even trickier. To value appropriately such complex securities, an investor would have had to evaluate the correlation structure for all the default events that had been disclosed in the pool. Following the increase in the house 
prices, the probabilities of default within the pool became highly correlated among each other, causing a severe volatility of the financial market with a significant spillover to other sectors, which were not directly linked to the mortgage market.

\section{4-A.3 Asset-backed securities}

An asset-backed security (ABS) is the main security that is created by a pool of mortgages. It is supplied by a special purpose vehicle (SPV), which buys a portfolio of risky assets by its originators and allocates the cash flows from the assets into three tranches: the senior tranche (with low returns and low risk), the mezzanine tranche (with medium returns and medium risk) and the equity tranche (with high returns and high risk). The principal of the portfolio is divided into the three above tranches and the portfolio's cash inflows are usually allocated firstly to the senior tranche until it is full, then to the mezzanine tranche and finally to the equity tranche. The lifespan of the ABS usually corresponds to that of the backed mortgages, while the average lifetime depends on the prepayments and defaults. If there are losses due to defaults from the equity tranche for example, these are covered by the principal of the mezzanine tranche and, respectively, losses from the mezzanine tranche - if it loses all its principal - are covered by the principal of the senior tranche. On the other hand, the initial cash inflows go first to the senior tranche, then to the mezzanine and then to the equity tranche. This process of cash inflows by interest and reverse cash outflows by losses is the so called "waterfall" of the ABS. It is therefore logical to give the senior tranche a very high rating (usually AAA/Aaa), the mezzanine tranche lower (around BBB/Baa), while the equity tranche is typically not rated. The basic aim of the creator of the ABS is to increase the senior tranche and at the same time to maintain its very high rating, maximizing the probability of the structure. She gathers information on how each credit agency evaluates the ABSs and then chooses, from numerous structures, the most suitable portfolio, which incorporates the highest rating. 
Clearly, the most lucrative tool for investors is the senior tranche of the CDS, while the equity tranche can be resold, for example, to a hedge fund. However, the mezzanine tranche is not so easily marketable. That is why the SPV can create another ABS with a senior tranche - from medium-rated tranches of the initial ABS and so increase the proportion of highly rated instruments. These specific types of ABS instruments are called Asset-Backed Security Collateralized Debt Obligations, ABS CDOs. The idea is to increase the portion of AAA-rated instruments to very high levels. But there is a tricky caveat. Even if the number of highly rated assets increases within the ABS CDO portfolio and senior tranches would suffer losses only if these losses exceed the level of the principal of the more junior tranches, there still remains a risk if this process is expanded.

In figure 1 (Gorton, 2007), we assume two ABS CDOs that are created from an ABS: one mezz ABS CDO (which is created by the mezzanine tranche) and one high grade ABS CDO (which is created by the senior tranche). Then based on the highest rated tranches of the mezz ABS CDO, we create another security with different rating levels. In essence, a third level of securitization is formulated and a CDO of the previous $\mathrm{CDO}$ is created $\left(\mathrm{CDO}^{2}\right)$. The mezzanine tranche of the initial security that was used to build the other two securities is highly risky itself. We now have the phenomenon of excess spread or over-collateralization, where the value of the mortgages is greater than the values of the securities, which are created via the ABS. More specifically, the average returns, which are promised to the security holders are less than the interest earned from the mortgage. If there were cases of cash leftovers when ABS tranches received all expected returns, then these cash flows would be used to reduce the principal of the senior tranches. ${ }^{128}$ This was actually the case for many investment banks and financial institutions, when senior tranches of mezzanine ABS CDOs with minimal capital

\footnotetext{
128 See Gorton (2007) for a further discussion on this securitization example.
} 
requirements promised higher expected returns than benchmark interest rates, which resulted in extensive losses.

Appendix 4-A / Figure 1: Third level securitization from subprime mortgage loans

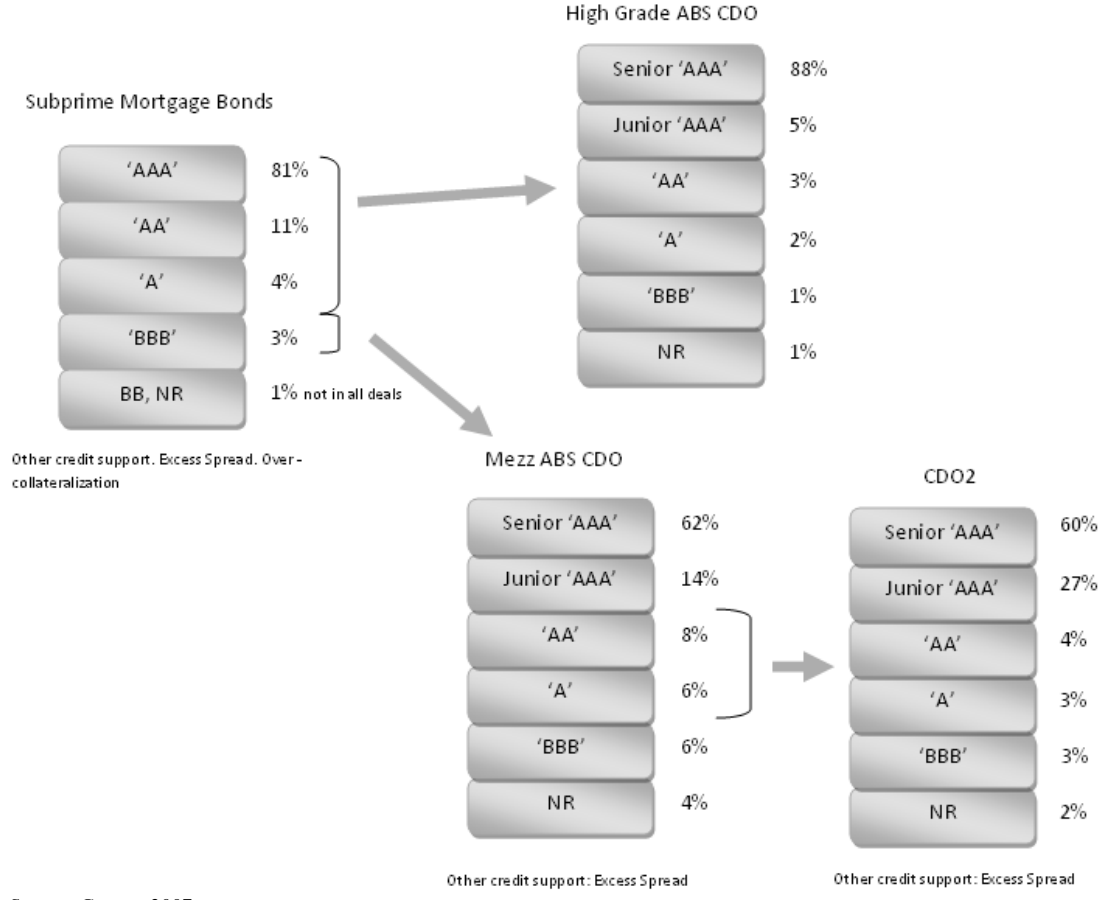

Source: Gorton, 2007.

\section{4-A.4 Complexity of off-balance sheet operations}

Securitization definitely played an important role in the evolvement of the crisis. The risks in securitization transactions are "guaranteed" by the advantages of the same transactions. Nevertheless, in order for a such a turmoil to occur, there should be some changes made in the system. Because the originator has the capacity to remove the entire credit portfolio off-balance, she does not have an incentive to make sure that loans incorporated in the securitized portfolio have certain minimum quality requirements. A regulatory requirement towards the originator to keep a specific part of the transaction on her books, could guarantee that no toxic waste "contaminates" the loan portfolio. This is because the 
originator is directly exposed to the portfolio's built-in risk. In order to assess the risk from a certain transaction, the originator should publicly declare the share and the tranches retained from the transaction. Firstly, if the share is too small, then the alliance of incentives is not realized. Secondly, if the share is too large, then the entire securitization itself becomes of no interest for the issuer. That is because more financial advantages can be pulled out from other forms of refinancing for example, the issuance of covered bonds. Consequently, the positive outcomes of securitization transaction for the economy disappear. If the originator is required to keep hold of a share of the transaction, then she will disburse her balance sheet. As a result of this, the number of loans that she can endow shrinks, since she cannot exceed a certain level of leverage.

Investors on the other hand have their own share of the pie. Many of them hunted AAA-related tranches of the ABS and $\mathrm{ABS} \mathrm{CDO}$ structures, by taking into consideration only the "AAA" label. These investors did not carefully look into the thin lines, which define a CDO squared, or an ABS CDO, or even a plain ABS. As a result of this negligence, the potential investors did not comprehend enough the portfolios and algorithms used to resolve the cash flows received by the range of tranches. Eventually, because the risk of these tranches was recognized, they were not easily tradable. The complexity of the credit derivatives that are being traded and the characteristics of the backed mortgages and the other mechanisms underlying these derivatives, should be transparently defined. Structures, tranches ${ }^{129}$ and cash flows should be properly defined, while the information about the tranches must be widely available to researchers and market actors. This could enhance the proper functionality of secondary financial markets.

${ }^{129}$ Which are usually defined by other tranches. 


\section{Appendix 5-A: The management of government guarantees}

Merton and Bodie (1992) examine the different aspects of public, but also private entities' guarantees in terms of effective management. They initially define the value of a loan guarantee as the difference between the guaranteed debt price and the non-guaranteed debt price. ${ }^{130}$ They verify previous valuation techniques developed by Merton (1977) and extend his analysis by arguing that guarantees must be large enough to cover both actuarial and operating costs. Still, the guarantor's maximum profit is the premium plus the interest earned for investing this premium prior to payment of losses, until the expiration of the guarantee. Therefore, the maximum loss exposure for the guarantor is given by:

$$
\mathrm{P}(1+\mathrm{r})-\max [0, \mathrm{E}-\mathrm{V}]
$$

, where $\mathrm{P}$ is the guarantee premium, $\mathrm{r}$ the interest rate, $\mathrm{E}$ the value of the collateral assets and $\mathrm{V}$ the promised debt payments. Respectively, the guarantor is exposed to the full downside risk of the collateral assets as if it owned the assets herself. The guarantor's expected profit is a decreasing function of the variability of the "shortfall," this being the difference between the expected debt payment and the price of the collateral assets at maturity.

The authors also propose a method for the guarantor to manage the guarantee risk, by charging risk-related premiums. Thus, the guarantor charges a fee that is commensurate by the riskiness of the guarantee. This assumes that the guarantor has some control over the volatility of the collateral asset portfolio that backs the guarantee. Nevertheless, this does not necessarily imply that the asset volatility has to be reduced to zero. It has to be at least acknowledged and also not subject to significant unilateral change by the insured intermediary after the premium has been determined. Then the guarantor faces a problem of moral hazard, since the management of the debt-

${ }^{130}$ They assume that a high-rated bond can be considered risk-free with a small guarantee component while a "junk" bond typically has a large guarantee component. 
holder is believed to have the incentive to increase the riskiness of the firm's assets (Merton, 1990). ${ }^{131}$ The value of the guarantees is essentially the price difference of two bonds, one with a guaranteed debt price and another without a guaranteed debt price (for example, corporate bonds). Merton and Bodie (1992) derived market values for guarantees by estimating the price of the latter bonds, assuming that they are risk-free. These bond prices were calculated by picking lowergraded bonds and by assuming their risk-free prices as the discounted promised coupon and principal payments at the current treasury bond rate. Therefore, simply by subtracting the actual market prices of these bonds, they estimated guarantee values.

Finally they focus their analysis on the management of government guarantees. On these terms they distinguish three types of risk: a) diversifiable risk that can be eliminated through pooling and diversification, b) non-diversifiable business cycle risk, such as interest rate and stock market risks and c) systemic risk that cannot be diversified or hedged via the financial markets. This latter risk is deemed to be faced via government interventions, as was the case in the current, but also in previous crises episodes. There are specific problems with government guarantees, mainly concerning pressures from interest groups for subsidizing, forbearance and eventually "cheap" government guarantees. Other concerns for the implementation of public insurance interventions, include avoiding market distortions and maintaining the market discipline that is essential for the viability of the guarantee scheme. As argued by Merton and Bodie (1992), "the government, therefore is caught in a paradox of power [...] where it must bind itself convincingly not to bail out institutions that get into trouble [...] but is too powerful not to intervene" (page 32).

\footnotetext{
${ }^{131}$ See Merton (1990) for a further discussion on moral hazard problems with guarantors.
} 


\section{Appendix 6-A: Complete set of intervention variables for decision model estimation}

\begin{tabular}{|c|c|}
\hline & $\begin{array}{l}\text { Variable Group A: Asset Management, Liabilities Management and Equity Management } \\
(\text { (yes / no) }\end{array}$ \\
\hline 1 & asset management (purchase plans and loan guarantees) \\
\hline 2 & liabilities management (deposit insurance and debt guarantees) \\
\hline \multirow[t]{2}{*}{3} & equity management (capital injections, recapitalization) \\
\hline & Variable Group B: Fiscal Cost Variables \\
\hline 1 & capital injections \\
\hline 2 & purchase of assets and lending by treasury \\
\hline 3 & central bank support provided with treasury backing \\
\hline 4 & liquidity provision and other support by central bank \\
\hline 5 & guarantees \\
\hline 6 & total fiscal costs \\
\hline \multirow[t]{2}{*}{7} & upfront government financing \\
\hline & Variable Group C: Financial Sector Variables \\
\hline 1 & bank assets / GDP \\
\hline 2 & bank liabilities / GDP \\
\hline 3 & bank loans / GDP \\
\hline 4 & bank deposits / GDP \\
\hline 5 & bank loans / bank deposits \\
\hline \multirow[t]{2}{*}{6} & bank concentration \\
\hline & Variable Group D: Macroeconomic Variables \\
\hline 1 & $\begin{array}{c}\text { real GDP growth } \\
\end{array}$ \\
\hline 2 & government balance (deficit/surplus) \\
\hline 3 & public debt (gross) \\
\hline 4 & current account balance \\
\hline \multirow[t]{2}{*}{5} & short term interest rates \\
\hline & Variable Group E: Banking Regulation Variables \\
\hline 1 & minimum capital to asset ratio requirement \\
\hline 2 & the minimum ratio variation as a function of an individual bank's credit risk \\
\hline 3 & the minimum ratio variation as a function of market risk \\
\hline 4 & leverage ratio requirement \\
\hline 5 & actual risk-adjusted capital ratio \\
\hline 6 & $\begin{array}{c}\text { actual ratio between shareholders' equity (Tier } 1 \text { regulatory capital) and total risk-weighted } \\
\text { assets }\end{array}$ \\
\hline 7 & fraction of the banking system's assets that are $50 \%$ or more government owned \\
\hline 8 & fraction of the banking systems' deposits that are $50 \%$ or more government owned \\
\hline 9 & fraction of the banking systems loans in banks that are $50 \%$ or more government owned \\
\hline 10 & supervisory authority force towards a bank to change its internal organizational structure \\
\hline 11 & explicit, verifiable, and quantifiable guidelines regarding asset diversification \\
\hline 12 & liquidity or deposit reserves requirement at the Central Bank \\
\hline 13 & $\begin{array}{l}\text { percent of the commercial banking system's assets in central government bonds or other } \\
\text { government or central bank securities }\end{array}$ \\
\hline 14 & percent of the commercial banking system's assets funded with deposits \\
\hline 15 & percent of the commercial banking system's assets funded with insured deposits \\
\hline 16 & explicit deposit insurance protection system \\
\hline 17 & deposit insurance protection system co-funded by the government \\
\hline 18 & public sector (co)-management of the insurance fund \\
\hline 19 & total amount of off-balance sheet items as \% of GDP \\
\hline 20.a & supervisory agency's suspension on the directors' decision to distribute dividends \\
\hline
\end{tabular}




\begin{tabular}{|c|c|}
$20 . \mathrm{b}$ & supervisory agency's suspension on the directors' decision to distribute bonuses \\
\hline $20 . \mathrm{c}$ & supervisory agency's suspension on the directors' decision to distribute management fees \\
\hline 21 & $\begin{array}{r}\text { establishment of predetermined levels of solvency (capital or net worth) deterioration which } \\
\text { forces automatic actions (like intervention) }\end{array}$ \\
\hline $22 . \mathrm{a}$ & $\begin{array}{r}\text { replacement of shareholder rights from the supervisory agency or any other government agency } \\
\text { regarding bank restructuring and reorganization }\end{array}$ \\
\hline $22 . \mathrm{b}$ & $\begin{array}{r}\text { removal and replacement of management from the supervisory agency or any other government } \\
\text { agency regarding bank restructuring and reorganization }\end{array}$ \\
\hline $22 . \mathrm{c}$ & $\begin{array}{r}\text { removal and replacement of directors from the supervisory agency or any other government } \\
\text { agency regarding bank restructuring and reorganization }\end{array}$ \\
\hline $22 . \mathrm{d}$ & $\begin{array}{r}\text { forbearance for certain prudential regulations from the supervisory agency or any other } \\
\text { government agency regarding bank restructuring and reorganization }\end{array}$ \\
\hline $22 . \mathrm{e}$ & $\begin{array}{r}\text { insurance of liabilities beyond any explicit deposit insurance scheme from the supervisory } \\
\text { agency or any other government agency regarding bank restructuring and reorganization }\end{array}$ \\
\hline 23 & $\begin{array}{r}\text { deposit coverage to GDP per capita ratio } \\
\hline\end{array}$ \\
\hline
\end{tabular}

Source: Author's contribution. 


\section{Appendix 6-B: Complete dataset of intervention variables for the $\mathbf{G 2 0}$ countries, year 2008}

Appendix 6-B / Table 1: Asset Management, Liabilities Management and Equity Management Variables

\begin{tabular}{|c|c|c|c|}
\hline \multicolumn{4}{|c|}{ Financial sector balance sheet interventions, G20, Spain and Netherlands } \\
\hline Country & $\begin{array}{l}\text { Asset Management } \\
\text { (purchase plans and } \\
\text { loan guarantees) }\end{array}$ & $\begin{array}{c}\text { Liabilities } \\
\text { Management } \\
\text { (deposit insurance } \\
\text { and debt } \\
\text { guarantees) }\end{array}$ & $\begin{array}{l}\text { Equity Management } \\
\text { (capital injections, } \\
\text { recapitalization) }\end{array}$ \\
\hline Argentina & No & No & No \\
\hline Australia & Yes & Yes & No \\
\hline Brazil & Yes & No & No \\
\hline Canada & Yes & Yes & No \\
\hline China & No & No & Yes \\
\hline France & Yes & Yes & Yes \\
\hline Germany & Yes & Yes & Yes \\
\hline India & No & No & No \\
\hline Indonesia & No & Yes & $\mathrm{No}$ \\
\hline Italy & Yes & Yes & Yes \\
\hline Japan & Yes & No & Yes \\
\hline Mexico & No & Yes & No \\
\hline Netherlands & No & Yes & Yes \\
\hline Russia & Yes & Yes & Yes \\
\hline Saudi Arabia & No & Yes & Yes \\
\hline South Africa & No & No & No \\
\hline Spain & Yes & Yes & Yes \\
\hline South Korea & Yes & Yes & Yes \\
\hline Turkey & No & No & No \\
\hline United Kingdom & Yes & Yes & Yes \\
\hline United States & Yes & Yes & Yes \\
\hline
\end{tabular}

Source: IMF, 2009. "Stocktaking of the G20 Responses to the Global Banking Crises,"

Note by the staff of the International Monetary Fund, International Monetary Fund, Washington D.C. 
Appendix 6-B / Table 2: Government interventions fiscal costs in \% of GDP, G20, Spain and the Netherlands

\begin{tabular}{|c|c|c|c|c|c|c|c|}
\hline \multicolumn{8}{|c|}{ Financial sector fiscal costs in \% of GDP, G20, Spain and Netherlands } \\
\hline Country & $\begin{array}{c}\text { Capital } \\
\text { Injections }\end{array}$ & $\begin{array}{c}\text { Purchase } \\
\text { of Assets } \\
\text { and } \\
\text { Lending } \\
\text { by } \\
\text { Treasury }\end{array}$ & $\begin{array}{c}\text { Central } \\
\text { Bank } \\
\text { Support } \\
\text { Provided } \\
\text { with } \\
\text { Treasury } \\
\text { Backing }\end{array}$ & $\begin{array}{c}\text { Liquidity } \\
\text { Provision } \\
\text { and } \\
\text { Other } \\
\text { Support } \\
\text { by } \\
\text { Central } \\
\text { Bank }\end{array}$ & Guarantees & Total & $\begin{array}{c}\text { Upfront } \\
\text { Government } \\
\text { Financing }\end{array}$ \\
\hline Argentina & 0,0 & 0,9 & 0,0 & 0,0 & 0,0 & 0,9 & 0,0 \\
\hline Australia & 0,0 & 0,7 & 0,0 & 0,0 & N/A & 0,7 & 0,7 \\
\hline Brazil & 0,0 & 0,0 & 0,0 & 1,5 & 0,0 & 1,5 & 0,0 \\
\hline Canada & 0,0 & 8,8 & 0,0 & 1,6 & 11,7 & 22,0 & 8,8 \\
\hline China & 0,5 & 0,0 & 0,0 & 0,0 & 0,0 & 0,5 & 0,0 \\
\hline France & 1,2 & 1,3 & 0,0 & 0,0 & 16,4 & 19,0 & 1,5 \\
\hline Germany & 3,7 & 0,4 & 0,0 & 0,0 & 17,6 & 21,7 & 3,7 \\
\hline India & 0,0 & 0,0 & 0,0 & 5,6 & 0,0 & 5,6 & 0,0 \\
\hline Indonesia & 0,0 & 0,0 & 0,0 & 0,0 & 0,1 & 0,1 & 0,1 \\
\hline Italy & 1,3 & 0,0 & 0,0 & 2,5 & 0,0 & 3,8 & 1,3 \\
\hline Japan & 2,4 & 6,7 & 0,0 & 0,0 & 3,9 & 12,9 & 0,2 \\
\hline Mexico & 0,0 & 0,0 & 0,0 & 0,0 & 0,2 & 0,2 & 0,0 \\
\hline Netherlands & 3,4 & 2,8 & 0,0 & 0,0 & 33,7 & 39,8 & 6,2 \\
\hline Russia & 0,1 & 0,4 & 2,9 & 3,2 & 0,5 & 7,1 & 0,6 \\
\hline Saudi Arabia & 0,6 & 0,6 & 0,0 & 8,2 & N/A & 9,4 & 1,2 \\
\hline South Africa & 0,0 & 0,0 & 0,0 & 0,0 & 0,0 & 0,0 & 0,0 \\
\hline Spain & 0,0 & 4,6 & 0,0 & 0,0 & 18,3 & 22,8 & 4,6 \\
\hline South Korea & 2,5 & 1,2 & 0,0 & 0,0 & 10,6 & 14,3 & 0,2 \\
\hline Turkey & 0,0 & 0,0 & 0,0 & 0,2 & 0,0 & 0,2 & 0,0 \\
\hline United Kingdom & 3,5 & 13,8 & 12,9 & 0,0 & 17,4 & 47,5 & 19,8 \\
\hline United States & 4,0 & 6,0 & 1,1 & 31,3 & 31,3 & 73,7 & 6,3 \\
\hline
\end{tabular}

Notes

1: India and Turkey provided only central bank liquidity support to financial institutions via extended liquidity facilities

2: Australian guarantees data were obtained from Bendeich, M., 2008. "Australia guarantees bank deposits to combat crisis,"

Reuters U.S. edition article, retrieved January 2nd 2010 from www.reuters.com

Source: International Monetary Fund, 2009

"The State of Public Finances: Outlook and Medium-Term Policies After the 2008 Crisis,"

Companion Paper, Seminar of the Executive Board of the IMF, 20th February 2009. 
Appendix 6-B / Table 3: Financial Sector Variables

\begin{tabular}{|c|c|c|c|c|c|c|}
\hline COUNTRY & 光穿完 & 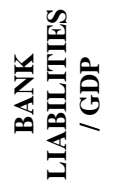 & 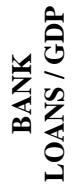 & 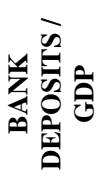 & 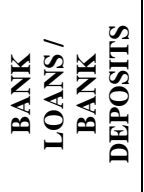 & 光茖面 \\
\hline Argentina & 0,054 & 0,087 & 0,048 & 0,085 & 0,558 & 0,425 \\
\hline Australia & 0,314 & 0,129 & 0,170 & 0,123 & 1,389 & 0,614 \\
\hline Brazil & 0,099 & 0,041 & 0,066 & 0,034 & 1,971 & 0,664 \\
\hline Canada & 0,243 & 0,119 & 0,175 & 0,111 & 1,578 & 0,565 \\
\hline China & 0,035 & 0,054 & 0,026 & 0,052 & 0,495 & 0,651 \\
\hline France & 0,633 & 0,401 & 0,483 & 0,375 & 1,289 & 0,583 \\
\hline Germany & 0,477 & 0,574 & 0,309 & 0,523 & 0,591 & 0,713 \\
\hline India & 0,111 & 0,037 & 0,094 & 0,029 & 3,226 & 0,333 \\
\hline Indonesia & 0,114 & 0,027 & 0,103 & 0,027 & 3,802 & 0,580 \\
\hline Italy & 0,499 & 0,142 & 0,250 & 0,120 & 2,089 & 0,354 \\
\hline Japan & 0,136 & 0,176 & 0,110 & 0,157 & 0,700 & 0,455 \\
\hline Mexico & 0,094 & 0,084 & 0,068 & 0,080 & 0,845 & 0,626 \\
\hline Netherlands & 1,499 & 1,037 & 1,027 & 0,950 & 1,081 & 0,754 \\
\hline Russia & 0,108 & 0,078 & 0,096 & 0,078 & 1,237 & 0,161 \\
\hline Saudi Arabia & 0,162 & 0,377 & 0,155 & 0,375 & 0,412 & 0,541 \\
\hline South Africa & 0,129 & 0,160 & 0,104 & 0,159 & 0,656 & 0,770 \\
\hline Spain & 0,687 & 0,195 & 0,397 & 0,173 & 2,287 & 0,751 \\
\hline South Korea & 0,196 & 0,061 & 0,131 & 0,053 & 2,475 & 0,527 \\
\hline Turkey & 0,196 & 0,089 & 0,175 & 0,089 & 1,968 & 0,462 \\
\hline $\begin{array}{l}\text { United } \\
\text { Kingdom }\end{array}$ & 1,873 & 1,706 & 1,540 & 1,487 & 1,036 & 0,599 \\
\hline United States & 0,371 & 0,285 & 0,260 & 0,263 & 0,988 & 0,339 \\
\hline
\end{tabular}

Notes

1. Data are retrieved from Table 6 of the BIS Quarterly Review:

"External positions of reporting banks vis-à-vis individual countries"

2: Figures are calculated as percentage of gross domestic product (\%GDP) in current prices

Billions of U.S. dollars. Source: IMF World Economic Output (WEO) Database, April 2009

3: Bank concentration was retrieved from Beck and Demirguc-Kunt's:

"A New Database on Financial Development and Structure". It is based on 2007 data and can be considered static

Source: Bank for International Settlements (BIS), BIS Quarterly Review, December 2009

BIS Locational Banking Statistics, retrieved January 30 th 2010 from www.bis.org/statistics/bankstats. 
Appendix 6-B / Table 4: Macroeconomic Variables

\begin{tabular}{|c|c|c|c|c|c|}
\hline \multicolumn{6}{|c|}{$\begin{array}{c}\text { Real GDP \% Growth, General Government Balance \% GDP, General Government Gross Debt } \\
\text { \% GDP, Current Account Balance \% GDP, Short Term Interest Rates }\end{array}$} \\
\hline Country & $\begin{array}{c}\text { Real } \\
\text { GDP } \\
\text { growth }\end{array}$ & $\begin{array}{c}\text { Government } \\
\text { balance } \\
\text { (deficit/surplus) }\end{array}$ & $\begin{array}{l}\text { Public debt } \\
\quad \text { (gross) }\end{array}$ & $\begin{array}{l}\text { Current } \\
\text { account } \\
\text { balance }\end{array}$ & $\begin{array}{l}\text { Short Term } \\
\text { Interest Rates }\end{array}$ \\
\hline Argentina & 6,969 & 1,400 & 48,800 & 1,356 & 9,048 \\
\hline Australia & 2,061 & 0,095 & 14,700 & $-6,295$ & 6,973 \\
\hline Brazil & 5,076 & 2,400 & 38,800 & $-1,799$ & 12,333 \\
\hline Canada & 0,457 & 0,401 & 63,626 & 0,639 & 3,307 \\
\hline China & 9,047 & $-0,800$ & 15,600 & 9,997 & 4,033 \\
\hline France & 0,716 & $-3,400$ & 67,295 & $-1,582$ & 4,634 \\
\hline Germany & 1,290 & $-0,134$ & 67,216 & 6,415 & 4,634 \\
\hline India & 7,288 & $-0,620$ & 56,400 & $-2,755$ & 5,917 \\
\hline Indonesia & 6,062 & $-0,100$ & 29,300 & 0,102 & 8,493 \\
\hline Italy & $-1,040$ & $-2,734$ & 105,813 & $-3,164$ & 4,634 \\
\hline Japan & $-0,641$ & $-5,552$ & 196,287 & 3,190 & 0,847 \\
\hline Mexico & 1,348 & $-1,500$ & 35,800 & $-1,427$ & 8,353 \\
\hline Netherlands & 2,012 & 0,789 & 58,200 & 4,412 & 4,634 \\
\hline Russia & 5,600 & 4,100 & 6,500 & 6,104 & 10,772 \\
\hline Saudi Arabia & 4,630 & 33,000 & 18,900 & 28,869 & 4,917 \\
\hline South Africa & 3,062 & $-1,000$ & 31,600 & $-7,407$ & 10,874 \\
\hline Spain & 1,158 & $-3,824$ & 40,700 & $-9,557$ & 4,634 \\
\hline South Korea & 2,224 & 1,115 & 24,400 & $-0,676$ & 5,488 \\
\hline Turkey & 1,060 & $-2,200$ & 40,000 & $-5,678$ & 15,500 \\
\hline United Kingdom & 0,707 & $-5,365$ & 51,922 & $-1,697$ & 5,491 \\
\hline United States & 1,111 & $-6,073$ & 70,517 & $-4,720$ & 2,965 \\
\hline
\end{tabular}

Notes

1: Short Term Interest Rates were received by OECD statistics database, OECD.StatExtracts.com, http://stats.oecd.org

2: Total Central Government Debt \% GDP for Australia, Mexico, Netherlands, Korea Rep., Spain and Turkey was retrieved from http://stats.oecd.org

3: Short Term Interest Rates for Argentina, Brazil, India, Saudi Arabia, Turkey was computed as an average of the Central Bank overnight rate,

source: www.tradingeconomics.com/Economics

4: Argentina's General Government Balance and Gross Debt were retrieved from Central Bank of Argentina, 2009.

5: Brazil's Central Government Primary Result was retrieved from Banco Central Do Brazil, Ministry of Finance,

5: Brazil's Central Government Primary Result wat
Economic indicators database, www.bcb.gov.br

6. General Government Gross Debt for Australia, Brazil, China, India, Indonesia, Mexico, Netherlands, Russian Fed., S.Arabia, S. 6: General Go
Africa, Spain,

South Korea and Turkey was retrieved from Central Intelligence Agency, 2009

"The World Factbook," from www.cia.gov/library/publications/the-world-factbook

7: Russian Government Budget surplus was retrieved from the U.S. Department of state, www.state.gov/r/pa/ei/bgn/3183.htm 8: South Africa Public finance fiscal balance was retrieved from

http://www.africaneconomicoutlook.org/en/countries/southern-africa/south-africa/\#/statistics_table

9: China's government budget deficit was obtained from Premier's Wen Jiabao press conference after the closing meeting of the

Second Session of the 11th National People's Congress (NPC) in Beijing, March 13, 2009

10: Indonesia's Budget Deficit was retrieved from Government of Indonesia evaluation of the economy in 2008 and outlook for 2009, www.indonesia.go.id

11: Mexico's Fiscal Deficit was retrieved from OECD Economic Surveys: Mexico, Volume 2009/11

12: Saudi Arabia's Fiscal Balance was retrieved from the 45th Annual Report: The Latest

Economic Developments of the Saudi Arabian Monetary Agency, Research and Statistics Department

Main source: International Monetary Fund, 2009. World Economic Outlook Report (WEO), WEO Database, April 2009. 
Appendix 6-B / Table 5: Banking Regulation Variables

\begin{tabular}{|c|c|c|c|c|c|c|c|c|c|c|c|c|c|c|c|c|c|c|c|c|}
\hline 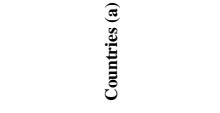 & 吾 & 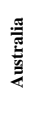 & 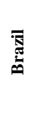 & 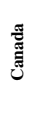 & 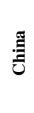 & 总 & है & 愛 & 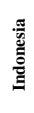 & 焉 & 离 & $\frac{8}{2}$ & 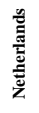 & $\begin{array}{l}\frac{\pi}{3} \\
\stackrel{2}{2} \\
\stackrel{2}{\approx}\end{array}$ & & क्ष & 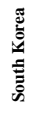 & 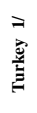 & 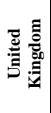 & 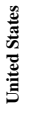 \\
\hline $\begin{array}{l}\text { minimum capital to asset } \\
\text { ratio requirement }\end{array}$ & $\stackrel{\infty}{0}$ & $\stackrel{\infty}{\circ}$ & $\overline{0}$ & $\stackrel{\infty}{\circ}$ & $\stackrel{\infty}{\circ}$ & $\frac{\pi}{\mathrm{z}}$ & $\stackrel{\infty}{\circ}$ & $\stackrel{\circ}{\circ}$ & $\stackrel{\infty}{\circ}$ & $\stackrel{\infty}{\circ}$ & $\stackrel{\infty}{\circ}$ & $\stackrel{\infty}{0}$ & $\stackrel{\infty}{\circ}$ & $\underset{0}{\overline{7}}$ & $\stackrel{\infty}{\circ}$ & $\stackrel{\infty}{\circ}$ & $\frac{\pi}{z}$ & $\stackrel{\infty}{\circ}$ & $\stackrel{\infty}{\circ}$ & $\stackrel{\infty}{\circ}$ \\
\hline $\begin{array}{l}\text { minimum ratio variation as a } \\
\text { function of an individual } \\
\text { bank's credit risk }\end{array}$ & $\stackrel{0}{0}$ & 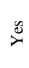 & $\stackrel{\circ}{z}$ & $\stackrel{\circ}{z}$ & そ & 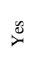 & $\stackrel{\circ}{z}$ & z & $\stackrel{0}{z}$ & $\stackrel{\circ}{z}$ & $\stackrel{\circ}{z}$ & $\stackrel{\circ}{2}$ & $\stackrel{\circ}{z}$ & $\triangleq$ & ż & $\overbrace{0}^{\circ}$ & $\stackrel{\circ}{z}$ & $\overbrace{0}^{0}$ & $\stackrel{0}{0}$ & 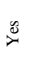 \\
\hline $\begin{array}{l}\text { minimum ratio variation as a } \\
\text { function of market risk }\end{array}$ & 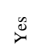 & $\frac{\varangle}{z}$ & 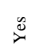 & $\stackrel{0}{z}$ & $\stackrel{0}{2}$ & $\ddot{\infty}$ & $\stackrel{\circ}{z}$ & $\stackrel{̊}{z}$ & $\stackrel{0}{z}$ & $\frac{\varangle}{z}$ & z̊ & z & 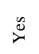 & $\stackrel{0}{\swarrow:}$ & z̊ & 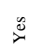 & z̊ & $\overbrace{0}^{\infty}$ & $\stackrel{0}{0}$ & $\stackrel{\circlearrowright}{\varnothing}$ \\
\hline leverage ratio requirement & $\stackrel{8}{z}$ & $\stackrel{8}{z}$ & $\stackrel{\circ}{z}$ & $\overbrace{0}^{\circ}$ & $\stackrel{8}{z}$ & $\stackrel{\circ}{z}$ & $\stackrel{0}{z}$ & $\stackrel{8}{z}$ & z̊ & $\frac{\pi}{z}$ & $\stackrel{\circ}{z}$ & $\frac{\pi}{z}$ & $\stackrel{\circ}{z}$ & そ & $\frac{\pi}{z}$ & $\stackrel{\circ}{2}$ & $\stackrel{\circ}{z}$ & $\frac{\pi}{z}$ & z̊ & 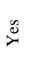 \\
\hline $\begin{array}{l}\text { actual risk-adjusted capital } \\
\text { ratio } 3 /\end{array}$ & $\frac{\pi}{0}$ & $\stackrel{m}{=}$ & $\stackrel{0}{0}$ & $\frac{\text { ते }}{0}$ & $\frac{9}{0}$ & $\stackrel{9}{\frac{0}{0}}$ & 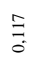 & 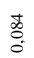 & $\stackrel{2}{2}$ & $\frac{8}{0}$ & $\frac{\pi}{0}$ & $\frac{9}{0}$ & $\frac{\pi}{0}$ & $\frac{8}{0}$ & $\stackrel{\infty}{\stackrel{\infty}{0}}$ & 三 & $\frac{\pi}{z}$ & $\frac{2}{0}$ & $\frac{\pi}{z}$ & $\frac{0}{3}$ \\
\hline $\begin{array}{l}\text { actual ratio between } \\
\text { shareholders' equity (Tier } 1 \\
\text { regulatory capital) and total } \\
\text { risk-weighted assets }\end{array}$ & $\frac{\stackrel{2}{0}}{0}$ & $\stackrel{0}{0}$ & $\frac{\mathrm{g}}{\mathrm{f}}$ & $\stackrel{2}{0}$ & $\stackrel{m}{0}$ & 占 & 菅 & 8 & $\frac{6}{0}$ & $\hat{\vdots}$ & $\frac{\pi}{z}$ & $\frac{\pi}{z}$ & $\overline{0}$ & $\underset{0}{ \pm}$ & $\frac{\bar{y}}{0}$ & 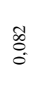 & $\stackrel{0}{0}$ & $\stackrel{\infty}{\infty}$ & $\begin{array}{l}\infty \\
\stackrel{0}{0}\end{array}$ & $\frac{\pi}{z}$ \\
\hline $\begin{array}{l}\text { fraction of the banking } \\
\text { system's assets that are } 50 \% \\
\text { or more government owned } \\
14\end{array}$ & $\stackrel{\text { Fे }}{0}$ & 0 & $\underset{\substack{f \\
0 \\
0}}{0}$ & o & $\begin{array}{l}\infty \\
: \\
: \\
0\end{array}$ & : & 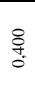 & 告 & $\begin{array}{l}\infty \\
\infty \\
0 \\
0 \\
0\end{array}$ & $\delta_{0}^{m}$ & $\frac{\pi}{z}$ & $\frac{\pi}{z}$ & 管 & $\begin{array}{l}\infty \\
\infty \\
0 \\
0 \\
0\end{array}$ & $\stackrel{\infty}{\frac{\infty}{0}}$ & o & $\stackrel{\substack{\infty \\
0}}{\circ}$ & $\frac{\infty}{m}$ & $\frac{\pi}{z}$ & $\frac{\pi}{z}$ \\
\hline $\begin{array}{l}\text { fraction of the banking } \\
\text { systems' deposits that are } \\
50 \% \text { or more government } \\
\text { owned } 4 /\end{array}$ & 年 & o & $\begin{array}{l}n \\
\substack{0 \\
0 \\
0}\end{array}$ & $\frac{\pi}{z}$ & 善 & $\overline{8}$ & 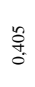 & E. & 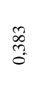 & gे & $\frac{0}{3}$ & $\frac{q^{2}}{0}$ & $\frac{\pi}{0}$ & $\stackrel{0}{0}$ & $\stackrel{\infty}{\stackrel{\infty}{0}}$ & 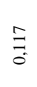 & $\frac{\pi}{z}$ & $\frac{2}{0}$ & $\frac{\pi}{z}$ & $\frac{0}{3}$ \\
\hline $\begin{array}{l}\text { fraction of the banking } \\
\text { systems loans in banks that } \\
\text { are } 50 \% \text { or more government } \\
\text { owned } 4 /\end{array}$ & $\overline{\bar{m}}$ & o & 离 & $\frac{\pi}{z}$ & $\stackrel{\circ}{:}$ & : & 旁 & 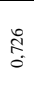 & हे & $\stackrel{\overrightarrow{0}}{0}$ & $\frac{\pi}{z}$ & $\frac{\pi}{z}$ & $\overline{8}$ & $\stackrel{m}{\vec{f}}$ & $\stackrel{\infty}{0}$ & o & $\frac{n}{d}$ & $\frac{\ll}{z}$ & $\frac{\varangle}{z}$ & \$. \\
\hline $\begin{array}{l}\text { supervisory authority force } \\
\text { towards a bank to change its } \\
\text { internal organizational } \\
\text { structure }\end{array}$ & z̊ & $\stackrel{0}{0}$ & 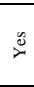 & $\stackrel{\circ}{z}$ & $\stackrel{0}{0}$ & 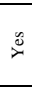 & 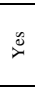 & $\stackrel{0}{0}$ & $\ddot{\nu}$ & $\underbrace{\mathscr{x}}$ & 乐 & $\stackrel{0}{\swarrow}$ & 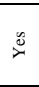 & 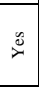 & $\stackrel{y}{\nu}$ & $\underbrace{\mathscr{x}}$ & $\stackrel{0}{x}$ & $\underbrace{0}$ & $\stackrel{0}{x}$ & $\underbrace{\circ}$ \\
\hline $\begin{array}{l}\text { explicit, verifiable, and } \\
\text { quantifiable guidelines } \\
\text { regarding asset } \\
\text { diversification } \\
\end{array}$ & $\ddot{\nu}$ & z & z̊ & $\overbrace{0}^{0}$ & $\stackrel{0}{\swarrow}$ & $\underbrace{\infty}_{\nu}$ & ż & 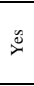 & $\stackrel{0}{0}$ & $\stackrel{\circ}{z}$ & 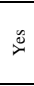 & $\stackrel{0}{0}$ & $\stackrel{\circ}{z}$ & z̊ & $\stackrel{\mathscr{c}}{0}$ & $\stackrel{\circ}{z}$ & $\stackrel{0}{\infty}$ & ż & $\stackrel{\circ}{z}$ & z \\
\hline $\begin{array}{l}\text { liquidity or deposit reserves } \\
\text { requirement at the Central } \\
\text { Bank }\end{array}$ & z̊ & $\stackrel{\circ}{z}$ & $\stackrel{\mathscr{c}}{\partial}$ & z̊ & $\stackrel{0}{0}$ & $\stackrel{\mathscr{C}}{\mathscr{c}}$ & $\stackrel{0}{0}$ & $\stackrel{\mathscr{c}}{0}$ & $\stackrel{0}{\nu}$ & 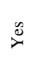 & 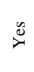 & $\stackrel{\infty}{\infty}$ & $\stackrel{\mathscr{C}}{0}$ & 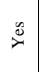 & $\stackrel{\varrho}{\nu}$ & $\stackrel{\mathscr{c}}{\check{c}}$ & 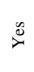 & $\overbrace{0}^{0}$ & $\stackrel{\mathscr{x}}{0}$ & 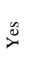 \\
\hline $\begin{array}{l}\text { percent of the commercial } \\
\text { banking system's assets in } \\
\text { central government bonds or } \\
\text { other government or central } \\
\text { bank securities }\end{array}$ & $\stackrel{m}{F}$ & $\frac{\pi}{z}$ & $\frac{1}{3}$ & $\stackrel{0}{0}$ & $\frac{\pi}{z}$ & $\stackrel{\circ}{\circ}$ & $\stackrel{t}{\circ}$ & $\frac{ \pm}{\frac{J}{3}}$ & స్ & $\stackrel{\circ}{\circ}$ & 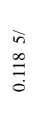 & $\frac{9}{0}$ & $\frac{3}{0}$ & $\stackrel{8}{0}$ & $\frac{\infty}{0}$ & $\begin{array}{l}0 \\
0 \\
0 \\
0 \\
0\end{array}$ & $\frac{\pi}{z}$ & $\begin{array}{c}\infty \\
\infty \\
\infty \\
0 \\
0\end{array}$ & \begin{tabular}{l}
3 \\
$\stackrel{3}{0}$ \\
\multirow{3}{0}{}
\end{tabular} & $\stackrel{\varrho}{0}$ \\
\hline $\begin{array}{l}\text { percent of the commercial } \\
\text { banking system's assets } \\
\text { funded with deposits }\end{array}$ & 它 & 㻤 & $\frac{f_{0}^{\prime}}{\text { f }}$ & $\vec{E}$ & $\begin{array}{c}\overrightarrow{0} \\
\substack{\infty \\
0}\end{array}$ & $\frac{\infty}{0}$ & 然 & $\underset{\substack{\delta \\
⿱ 亠 䒑}}{\substack{\infty \\
\hdashline}}$ & 害 & $\begin{array}{l}\mathscr{D} \\
\infty \\
0 \\
0\end{array}$ & $\frac{8}{8}$ & 啇 & $\stackrel{8}{\stackrel{2}{7}}$ & $\begin{array}{l}0 \\
\infty \\
\infty \\
0 \\
0 \\
0\end{array}$ & 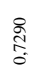 & 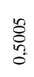 & 啇 & $\begin{array}{l}0 \\
0 \\
0 \\
0 \\
0\end{array}$ & $\begin{array}{l}\hat{n} \\
\tilde{n} \\
\text { on }\end{array}$ & 号 \\
\hline $\begin{array}{l}\text { percent of the commercial } \\
\text { banking system's assets } \\
\text { funded with insured deposits }\end{array}$ & \& & o & o & $\frac{\pi}{z}$ & o & : & $\frac{\pi}{z}$ & $\frac{\pi}{z}$ & 声 & $\infty$ & $\frac{\pi}{z}$ & 待 & 辛 & $\frac{\pi}{z}$ & $\frac{\ll}{z}$ & ले & $\stackrel{m}{m}$ & ह & $\frac{\pi}{z}$ & $\begin{array}{l}\bar{w} \\
\vdots \\
0 \\
0\end{array}$ \\
\hline $\begin{array}{l}\text { explicit deposit insurance } \\
\text { protection system }\end{array}$ & $\stackrel{\infty}{\check{x}}$ & \& & $\stackrel{0}{x}$ & 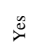 & そ & $\stackrel{0}{0}$ & 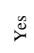 & $\stackrel{\Leftrightarrow}{0}$ & $\stackrel{0}{0}$ & 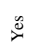 & $\stackrel{0}{0}$ & 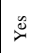 & 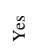 & 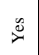 & そ & $\stackrel{\mathscr{x}}{0}$ & 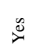 & $\check{\check{c}}$ & 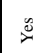 & $\stackrel{\circlearrowright}{\check{\nu}}$ \\
\hline $\begin{array}{l}\text { deposit insurance protection } \\
\text { system co-funded by the } \\
\text { government }\end{array}$ & z̊ & $\frac{\pi}{z}$ & $\stackrel{8}{2}$ & $\stackrel{2}{2}$ & $\frac{\pi}{z}$ & $\check{z}$ & $\stackrel{2}{2}$ & $\stackrel{\mathscr{c}}{\check{\nu}}$ & $\stackrel{\mathscr{c}}{\check{\nu}}$ & そ̊ & 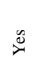 & $\stackrel{0}{0}$ & $\stackrel{\circ}{z}$ & 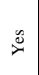 & $\frac{\ll}{z}$ & $\stackrel{\circ}{z}$ & $\stackrel{\mathscr{c}}{:}$ & 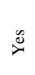 & z̊ & z̊ \\
\hline
\end{tabular}




\begin{tabular}{|c|c|c|c|c|c|c|c|c|c|c|c|c|c|c|c|c|c|c|c|c|}
\hline $\begin{array}{l}\text { public sector (co)- } \\
\text { management of the insurance } \\
\text { fund }\end{array}$ & $\stackrel{\circ}{z}$ & $\frac{\pi}{z}$ & 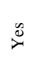 & 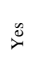 & $\frac{\pi}{z}$ & $\stackrel{\circ}{z}$ & $\stackrel{\circ}{z}$ & $\stackrel{0}{=}$ & $\stackrel{0}{0}$ & $\stackrel{0}{z}$ & $\frac{\pi}{z}$ & 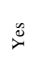 & 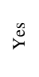 & $\stackrel{0}{0}$ & $\frac{\ll}{z}$ & $\stackrel{\mathscr{c}}{:}$ & $\stackrel{\tilde{c}}{:}$ & 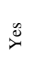 & $\stackrel{\circ}{2}$ & $\frac{\pi}{z}$ \\
\hline $\begin{array}{l}\text { total amount of off-balance } \\
\text { sheet items as \% of GDP } 9 /\end{array}$ & $\frac{5}{0}$ & $\begin{array}{l}\frac{\hbar}{n} \\
\stackrel{n}{5} \\
\frac{1}{5}\end{array}$ & $\frac{\ll}{z}$ & $\frac{\pi}{z}$ & $\frac{\pi}{z}$ & $\frac{\pi}{z}$ & $\begin{array}{l}\text { : } \\
\text { iे }\end{array}$ & $\frac{\pi}{z}$ & $\begin{array}{l}\text { के } \\
\text { c్d } \\
\text { i. }\end{array}$ & సิ & $\frac{\pi}{z}$ & $\frac{\varangle}{z}$ & 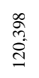 & $\begin{array}{l}\stackrel{\infty}{\infty} \\
\infty \\
\infty\end{array}$ & $\begin{array}{l}\text { N } \\
\hat{n} \\
\infty\end{array}$ & $\stackrel{\circ}{\circ}$ & 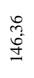 & $\frac{\varangle}{z}$ & $\frac{\mathbb{z}}{\mathrm{z}}$ & $\begin{array}{l}\text { ñ. } \\
\infty \\
\text { s. }\end{array}$ \\
\hline $\begin{array}{l}\text { supervisory agency's } \\
\text { suspension on the directors' } \\
\text { decision to distribute } \\
\text { dividends }\end{array}$ & : & $\stackrel{0}{i}$ & $\stackrel{0}{0}$ & $\stackrel{\circ}{z}$ & 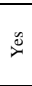 & 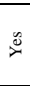 & $\overbrace{i=}^{*}$ & $\stackrel{\mathscr{E}}{-}$ & $\stackrel{0}{:}$ & $\stackrel{\circ}{z}$ & $\stackrel{\mathscr{C}}{:}$ & $\overbrace{0}^{*}$ & $\frac{\pi}{z}$ & $\stackrel{0}{*}^{*}$ & $\stackrel{8}{x}$ & 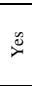 & 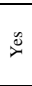 & $\overbrace{્}^{\infty}$ & $\stackrel{2}{z}$ & $\stackrel{\mathscr{J}}{\partial}$ \\
\hline $\begin{array}{l}\text { supervisory agency's } \\
\text { suspension on the directors' } \\
\text { decision to distribute bonuses }\end{array}$ & $\stackrel{0}{0}$ & $\stackrel{0}{:=0}$ & 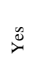 & $\stackrel{2}{Z}$ & 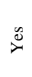 & z & そ & $\stackrel{0}{=}$ & $\stackrel{\tilde{0}}{0}$ & $\stackrel{0}{z}$ & 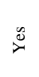 & 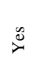 & $\frac{\pi}{z}$ & ż & $\overbrace{}^{\tilde{s}}$ & $\stackrel{0}{z}$ & 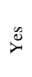 & $\stackrel{\mathscr{0}}{0}$ & $\stackrel{0}{2}$ & $\stackrel{丶}{ٍ}$ \\
\hline $\begin{array}{c}\text { supervisory agency's } \\
\text { suspension on the directors' } \\
\text { decision to distribute } \\
\text { management fees } \\
\end{array}$ & $\stackrel{0}{\check{0}}$ & $\triangleq$ & $\stackrel{\mathscr{c}}{\stackrel{0}{0}}$ & $\stackrel{0}{z}$ & $\frac{\pi}{z}$ & そ & $\stackrel{8}{2}$ & $\stackrel{\infty}{\infty}$ & $\stackrel{0}{0}$ & $\stackrel{0}{z}$ & $\stackrel{\mathscr{C}}{\mathscr{C}}$ & $\stackrel{0}{2}$ & $\frac{\pi}{z}$ & z & $\stackrel{\infty}{x}$ & $\stackrel{0}{z}$ & $\stackrel{\mathscr{c}}{:}$ & 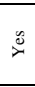 & $\stackrel{0}{z}$ & $\stackrel{\mathscr{0}}{0}$ \\
\hline $\begin{array}{c}\text { establishment of } \\
\text { predetermined levels of } \\
\text { solvency (capital or net } \\
\text { worth) deterioration which } \\
\text { forces automatic actions (like } \\
\text { intervention) }\end{array}$ & $\stackrel{\circ}{z}$ & $\stackrel{0}{0}$ & $\stackrel{\circ}{z}$ & $\stackrel{\circ}{z}$ & $\stackrel{\circ}{z}$ & $\stackrel{\circ}{z}$ & 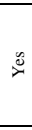 & $\frac{\partial}{\circ}$ & $\stackrel{0}{\check{\nu}}$ & $\stackrel{0}{z}$ & 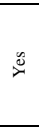 & $\overbrace{\sim}^{\infty}$ & $\stackrel{2}{z}$ & 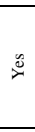 & $\stackrel{\circ}{z}$ & 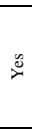 & 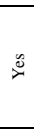 & 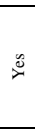 & $\stackrel{\circ}{z}$ & $\stackrel{\mathscr{c}}{\vec{c}}$ \\
\hline $\begin{array}{l}\text { replacement of shareholder } \\
\text { rights from the supervisory } \\
\text { agency or any other } \\
\text { government agency } \\
\text { regarding bank restructuring } \\
\text { and reorganization } 11 / \\
\end{array}$ & 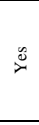 & 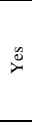 & $\stackrel{0}{0}$ & 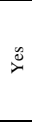 & 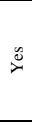 & 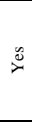 & $\stackrel{\circ}{z}$ & $\stackrel{z}{z}$ & $\stackrel{\tilde{0}}{\tilde{\nu}}$ & 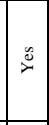 & :्र & $\stackrel{\infty}{\check{\infty}}$ & 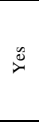 & $\stackrel{2}{z}$ & 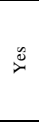 & 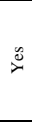 & 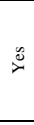 & $\stackrel{\mathscr{0}}{\check{\nu}}$ & $\stackrel{\mathscr{2}}{:}$ & $\stackrel{\mathscr{c}}{\mathscr{c}}$ \\
\hline $\begin{array}{l}\text { removal and replacement of } \\
\text { management from the } \\
\text { supervisory agency or any } \\
\text { other government agency } \\
\text { regarding bank restructuring } \\
\text { and reorganization 11/ } \\
\end{array}$ & $\stackrel{0}{=}$ & $\overbrace{0}^{\infty}$ & 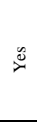 & $\overbrace{0}^{\tilde{c}}$ & 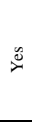 & $\stackrel{\circ}{z}$ & 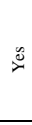 & $\stackrel{\infty}{\infty}$ & $\stackrel{0}{\nu}$ & $\stackrel{\circ}{z}$ & 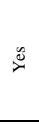 & $\check{\nu}^{0}$ & 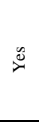 & $\check{\nu}_{0}^{u}$ & 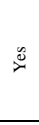 & 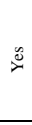 & 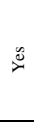 & $\stackrel{\mathscr{0}}{\check{0}}$ & $\stackrel{\ddot{c}}{0}$ & $\stackrel{0}{\tilde{c}}$ \\
\hline $\begin{array}{l}\text { removal and replacement of } \\
\text { directors from the } \\
\text { supervisory agency or any } \\
\text { other government agency } \\
\text { regarding bank restructuring } \\
\text { and reorganization 11/ }\end{array}$ & $\stackrel{\mathscr{0}}{:}$ & 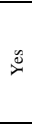 & 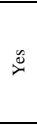 & 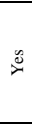 & 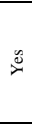 & 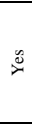 & $\stackrel{\circ}{z}$ & 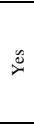 & $\stackrel{\tilde{0}}{2}$ & 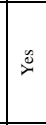 & 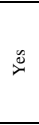 & $\stackrel{\infty}{\infty}$ & 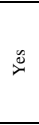 & 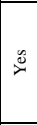 & 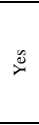 & 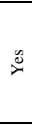 & 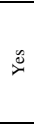 & $\stackrel{\mathscr{u}}{0}$ & 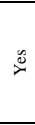 & 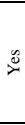 \\
\hline $\begin{array}{l}\text { forbearance for certain } \\
\text { prudential regulations from } \\
\text { the supervisory agency or } \\
\text { any other government agency } \\
\text { regarding bank restructuring } \\
\text { and reorganization 11/ }\end{array}$ & $\stackrel{\mathscr{c}}{0}$ & $\stackrel{0}{x}$ & $\stackrel{0}{0}$ & $\stackrel{\circ}{z}$ & $\stackrel{0}{0}$ & $\stackrel{\circ}{z}$ & $\check{c}_{0}^{0}$ & $\overbrace{0}^{0}$ & $\stackrel{0}{0}$ & 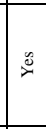 & 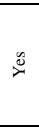 & 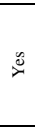 & 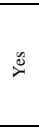 & 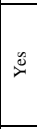 & $\stackrel{\dot{0}}{\sigma^{2}}$ & 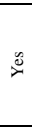 & $\stackrel{\substack{0 \\
:}}{0}$ & $\overbrace{\sim=}^{\infty}$ & $\stackrel{\leftrightarrow}{\circ}$ & 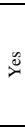 \\
\hline $\begin{array}{l}\text { insurance of liabilities } \\
\text { beyond any explicit deposit } \\
\text { insurance scheme from the } \\
\text { supervisory agency or any } \\
\text { other government agency } \\
\text { regarding bank restructuring } \\
\text { and reorganization 11/ } \\
\end{array}$ & $\stackrel{2}{z}$ & $\stackrel{2}{2}$ & 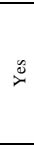 & $\stackrel{8}{2}$ & $\frac{\pi}{z}$ & $\stackrel{\mathscr{c}}{\circ}$ & $\stackrel{\circ}{z}$ & $\stackrel{z}{z}$ & z & $\stackrel{\circ}{z}$ & $\stackrel{0}{0}$ & $\stackrel{\circ}{2}$ & $\frac{\pi}{z}$ & $\stackrel{z}{z}$ & z & 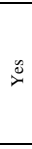 & 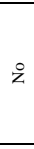 & 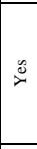 & 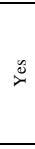 & z \\
\hline $\begin{array}{l}\text { deposit coverage to GDP per } \\
\text { capita ratio } / 15\end{array}$ & $\stackrel{\circ}{\stackrel{m}{~}}$ & $\frac{\pi}{z}$ & $\stackrel{\overbrace{}}{\mathrm{i}}$ & $\underset{-}{\mathcal{S}}$ & $\frac{\pi}{z}$ & $\stackrel{R}{i}$ & $\stackrel{\infty}{\infty}$ & $\begin{array}{c}\infty \\
\infty \\
\infty\end{array}$ & $\frac{\pi}{z}$ & $\stackrel{\infty}{\rightarrow+}$ & in & 声 & $\stackrel{8}{\pi}$ & $\stackrel{\infty}{-}$ & $\frac{\ll}{z}$ & $\exists$ & ले & ज̂ & $\stackrel{\triangleright}{-}$ & to \\
\hline
\end{tabular}

Notes
$1 /$ data for Turkey are for year 2003 except for the variables a) actual risk-adjusted capital ratio, b) actual ratio between shareholders' equity (Tier 1 regulatory

and total risk-weighted assets and c) fraction of the banking system's assets that are 50\% or more government owned that are for year 2001 $2 / 11 \%$ for banks with own funds less than rouble equivalent of 5 million euro, $10 \%$ for the rest $3 /$ as of year-end 2005, using the 1988 Basle Accord definitions

$4 /$ as of year-end 2005

$5 /$ as of end March, 2006. The branches of foreign banks are not included in this figure

T-Bills and Gilts excluding credit unions and Central Bank

Derate insured.

作

/ $/$ all off-balance sheet items disclosed to the supervisor and the public at year-end 2005 .

The figures were calculated as \% of GDP constant prices (source: IMF WEO 2009 database) for the same yea

10/ however, RBI has recently put in place a Prompt Corrective Action (PCA) framewo

under which certain interventions by supervisor are envisaged with some predetermined levels of solvency deterioration

11/ supervisory agencies and other government agencies are Bank Supervisor, Court, Deposit Insurance Agency, Bank Restructurit
12 f for year 2005. The figures were calculated as \% of GDP constant prices (Source IMF WEO 2009 database) for the same year

13/206.556 million euro, credit guarantee commitments; 1.171 .263 million euro, commitments and risks (others)

(intrinsic value of derivatives is included); 1.800 .000 million euro, securities held for safekeeping

14/ off-balance claims 1.462 billion RUR, off-balance liabilities 1.353 billion RUR

15/ Source: Demirgüç-Kunt A.,Karacaovali, B., and Laeven, L., 2005. "Deposit Insurance around the World: A Comprehensive Database,

World Bank Policy Research Working Paper 3628, The World Bank, data as of year-end 2003

Main source: Levine, R., Barth, J., and Caprio, G., 2008. "Bank Regulation and Supervision," $3^{\text {rd }}$ update of the Bank Regulation and Supervision Database, June 2008, Finance and Private Sector Research, the World Bank 


\section{Appendix 6-C: Additional dataset of intervention variables for the G20 countries, year 2007}

Appendix 6-C / Table 1: Financial Sector Variables, 2007

\begin{tabular}{|c|c|c|c|c|c|c|c|c|}
\hline COUNTRY & 类产 & 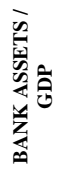 & 同密 & 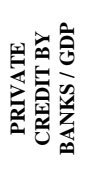 & 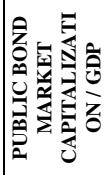 & 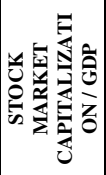 & 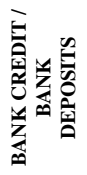 & 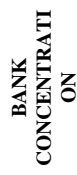 \\
\hline Argentina & 0,204 & 0,228 & 0,279 & 0,121 & 0,237 & 0,320 & 0,619 & 0,425 \\
\hline Australia & 0,854 & 1,142 & 0,889 & 1,138 & 0,131 & 1,466 & 1,269 & 0,614 \\
\hline Brazil & 0,552 & 0,768 & 0,582 & 0,374 & 0,461 & 0,794 & 0,721 & 0,664 \\
\hline Canada & 1,324 & 1,413 & 1,232 & 1,302 & 0,513 & 1,474 & 1,140 & 0,565 \\
\hline China & 1,607 & 2,108 & N/A & N/A & 0,294 & 1,318 & 0,796 & 0,651 \\
\hline France & 0,676 & 1,158 & 0,744 & 0,993 & 0,514 & 1,022 & 1,497 & 0,583 \\
\hline Germany & 1,010 & 1,270 & 1,086 & 1,052 & 0,399 & 0,571 & 1,006 & 0,713 \\
\hline India & 0,576 & 0,611 & 0,683 & 0,434 & 0,310 & 1,127 & 0,745 & 0,333 \\
\hline Indonesia & 0,341 & 0,315 & 0,383 & 0,227 & 0,170 & 0,407 & 0,680 & 0,580 \\
\hline Italy & 0,607 & 1,161 & 0,680 & 0,965 & 0,791 & 0,502 & 1,518 & 0,354 \\
\hline Japan & 1,862 & 1,533 & 1,978 & 0,968 & 1,599 & 1,058 & 0,518 & 0,455 \\
\hline Mexico & 0,212 & 0,297 & 0,247 & 0,169 & 0,203 & 0,420 & 0,813 & 0,626 \\
\hline Netherlands & 1,159 & 1,889 & 1,219 & 1,791 & 0,391 & 1,158 & 1,575 & 0,754 \\
\hline Russian Federation & 0,270 & 0,349 & 0,377 & 0,316 & 0,029 & 0,996 & 1,196 & 0,161 \\
\hline Saudi Arabia & 0,385 & 0,485 & 0,506 & 0,366 & N/A & 1,107 & 0,933 & 0,541 \\
\hline South Africa & 0,601 & 0,817 & 0,441 & 0,755 & 0,258 & 2,808 & 1,262 & 0,770 \\
\hline Spain & 1,214 & 1,795 & 1,293 & 1,685 & 0,333 & 1,098 & 1,399 & 0,751 \\
\hline South Korea & 0,634 & 1,076 & 0,661 & 1,009 & 0,481 & 1,015 & 1,685 & 0,527 \\
\hline Turkey & 0,377 & 0,459 & 0,405 & 0,261 & 0,305 & 0,343 & 0,721 & 0,462 \\
\hline United Kingdom & 1,402 & 1,737 & 1,402 & 1,742 & 0,321 & 1,414 & 1,246 & 0,599 \\
\hline United States & 0,738 & 0,659 & 0,716 & 0,604 & 0,468 & 1,437 & 0,805 & 0,339 \\
\hline
\end{tabular}

Notes

1: Bank concentration shows the assets of three largest banks as a share of assets of all commercial banks

2: China's Bank Deposits/ GDP and Bank Assets/ GDP were retrieved from China Banking Regulatory Commission,

2008. "2007 Annual Report,” China Banking Regulatory Commission (CBRC), Beijing

Source: Beck T., Demirguc-Kunt A., and Levine, R., 2000. "A New Database on Financial Development and Structure,"

World Bank Economic Review 14, pages 597-605, the World Bank, Washington D.C. 
Appendix 6-C / Table 2: Macroeconomic Variables, 2007

\begin{tabular}{|l|c|c|c|c|c|}
\hline \multicolumn{2}{|c|}{$\begin{array}{c}\text { Real GDP \% Growth, General Government Balance in \% GDP, General Government } \\
\text { Gross Debt \% GDP, Current Account Balance in \% GDP, Short Term Interest rate }\end{array}$} \\
\hline Country & $\begin{array}{c}\text { Real GDP } \\
\text { growth }\end{array}$ & $\begin{array}{c}\text { General } \\
\text { government } \\
\text { balance }\end{array}$ & $\begin{array}{c}\text { General } \\
\text { government } \\
\text { gross debt }\end{array}$ & $\begin{array}{c}\text { Current } \\
\text { account } \\
\text { balance }\end{array}$ & $\begin{array}{c}\text { Short } \\
\text { Term } \\
\text { Interest } \\
\text { Rates }\end{array}$ \\
\hline Argentina & 8,653 & 1,1 & 56,1 & 1,649 & 7,78 \\
\hline Australia & 4,049 & 1,509 & 5,4 & $-6,295$ & 6,67 \\
\hline Brazil & 5,67 & 2,2 & 45,1 & 0,116 & 11,97 \\
\hline Canada & 2,531 & 1,580 & 64,17 & 1,018 & 4,62 \\
\hline China & 13,012 & $-0,4$ & 18,4 & 10,993 & 3,51 \\
\hline France & 2,26 & $-2,726$ & 63,78 & $-0,996$ & 4,28 \\
\hline Germany & 2,516 & $-0,472$ & 63,437 & 7,52 & 4,28 \\
\hline India & 9,372 & $-3,17$ & 58,2 & $-1,025$ & 6 \\
\hline Indonesia & 6,278 & $-1,3$ & 34 & 2,429 & 7,98 \\
\hline Italy & 1,564 & $-1,503$ & 103,497 & $-2,418$ & 4,28 \\
\hline Japan & 2,337 & $-2,523$ & 187,708 & 4,816 & 0,75 \\
\hline Mexico & 3,33 & 0 & 21 & $-0,812$ & 7,78 \\
\hline Netherlands & 3,613 & 0,474 & 37,9 & 7,646 & 4,28 \\
\hline Russian Federation & 8,1 & 5,5 & 5,9 & 5,95 & 6,66 \\
\hline Saudi Arabia & 3,314 & 13 & 24,3 & 24,313 & 5,45 \\
\hline South Africa & 5,098 & 0,9 & 31,3 & $-7,307$ & 9,12 \\
\hline Spain & 3,565 & 2,209 & 30,1 & $-10,01$ & 4,28 \\
\hline South Korea & 5,106 & 3,469 & 29,7 & 0,56 & 5,16 \\
\hline Turkey & 4,669 & $-13,73$ & 39,6 & $-5,805$ & 17,167 \\
\hline United Kingdom & 2,559 & $-2,637$ & 44,127 & $-2,696$ & 5,95 \\
\hline United States & 2,141 & $-2,837$ & 61,871 & $-5,161$ & 5,27 \\
\hline
\end{tabular}

Notes

1: Short Term Interest Rates were received by OECD statistics database, OECD.StatExtracts.com, http://stats.oecd.org 2: Total Central Government Debt \% of GDP for Australia, Mexico, Netherlands, Korea Rep.,

Spain and Turkey was retrieved from http://stats.oecd.org

3: Short Term Interest Rates for Argentina, Brazil, India, Saudi Arabia, Turkey was computed as an average of the

Central Bank overnight rate, source: www.tradingeconomics.com/Economics

4: Argentina's General Government Balance and Gross Debt were retrieved from Central Bank of Argentina, 2009.

"Macroeconomic Radar," www.bcra.gov.ar

5: Brazil's Central Government Primary Result was retrieved from Banco Central Do Brazil, Ministry of Finance,

Economic indicators database, www.bcb.gov.br

6: General Government Gross Debt for Brazil, China, India, Indonesia, Russian Fed., S.Arabia, S. Africa was retrieved from

Central Intelligence Agency, 2009. "The World Factbook," from www.cia.gov/library/publications/the-world-factbook

7: China's Fiscal Deficit was retrieved from People's Bank of China, 2008. "China Financial Stability Report"

8: Indonesia's Government Budget deficit was retrieved from "Indonesia: Economic and Social update,"

April 2008, the World Bank, Washington D.C.

9: Russian Federation's Government Budget surplus was retrieved from the U.S. Department of State,

www.state.gov/r/pa/ei/bgn/3183.htm

10: Mexico Government Balance was retrieved from Library of Congress, 2008.

"Country profile: Mexico," Federal Research Division, July 2008.

11. South Africa Public finance fiscal balance was retrieved from

http://www.africaneconomicoutlook.org/en/countries/southern-africa/south-africa/\#/statistics_table

12: Turkey's Central Government deficit was retrieved from Turkish Embassy London, 2009.

"Economic Outlook of Turkey," Office of the First Economic Counsellor, www.turkisheconomy.org.uk

Main source: International Monetary Fund, 2009f. "World Economic Output Report,"

World Economic Output (WEO) Database, April 2009, International Monetary Fund, Washington D.C. 


\section{Appendix 6-D: Additional tables for simple logit regression results and the $\log$ odds for significant variables}

Appendix 6-D / Table 1: Logit regression results for one intervention (with standard errors and confidence intervals)

Group A: variables related to the asset intervention

\begin{tabular}{|c|c|c|c|c|}
\hline & Coefficient & Significance: $\mathrm{P}>|\mathrm{z}|$ & $\begin{array}{l}\text { Standard } \\
\text { Error }\end{array}$ & Expected sign \\
\hline asset purchases & 0.606 & 0.685 & 1.471 & + \\
\hline deposit protection & 1.705* & 0.054 & 0.829 & + \\
\hline bank assets & 1.171 & 0.944 & 16.496 & + \\
\hline \multicolumn{5}{|c|}{ Group L: variables related to the liabilities intervention } \\
\hline & Coefficient & Significance: $\mathrm{P}>|\mathrm{z}|$ & $\begin{array}{l}\text { Standard } \\
\text { Error }\end{array}$ & Expected sign \\
\hline guarantees & $0.305 * *$ & 0.001 & 0.076 & + \\
\hline $\begin{array}{c}\text { government own. } \\
\text { loans }\end{array}$ & $-12.416 * *$ & 0.000 & 1.978 & - \\
\hline bank liabilities & 10.232 & 0.174 & 7.252 & + \\
\hline \multicolumn{5}{|c|}{ Group E: variables related to the equity intervention } \\
\hline & Coefficient & Significance: $\mathrm{P}>|\mathrm{z}|$ & $\begin{array}{l}\text { Standard } \\
\text { Error }\end{array}$ & Expected sign \\
\hline capital ratio & -38.63 & 0.297 & 35.938 & - \\
\hline government bonds & $-12.635 *$ & 0.084 & 6.882 & - \\
\hline solvency target & -0.223 & 0.820 & 0.965 & + \\
\hline
\end{tabular}

Appendix 6-D / Table 2: Logit regression results for a mix of two interventions (with standard errors and confidence intervals) conditional variables for asset interventions (two regressions with one explanatory variable each)

\begin{tabular}{|c|c|c|c|}
\hline & Coefficient & Significance: $\mathrm{P}>|\mathrm{z}|$ & Standard Error \\
\hline guarantees & 0.077 & 0.170 & 0.056 \\
\hline capital injections & 0.614 & 0.123 & 0.399 \\
\hline \multicolumn{4}{|c|}{$\begin{array}{c}\text { conditional variables for liabilities interventions } \\
\text { (two regressions with one explanatory variable each) }\end{array}$} \\
\hline & Coefficient & Significance: $P>|z|$ & Standard Error \\
\hline asset purchases & 0.199 & 0.315 & 0.198 \\
\hline capital injections & 0.667 & 0.161 & 0.476 \\
\hline \multicolumn{4}{|c|}{$\begin{array}{c}\text { conditional variables for equity interventions } \\
\text { (two regressions with one explanatory variable each) }\end{array}$} \\
\hline & Coefficient & Significance: $\mathrm{P}>|\mathrm{z}|$ & Standard Error \\
\hline asset purchases & 0.201 & 0.249 & 0.175 \\
\hline guarantees & $0.194 *$ & 0.053 & 0.1 \\
\hline
\end{tabular}


Appendix 6-D / Table 3: Logit regression results for a mix of three interventions (with standard errors and confidence intervals) conditional variables for asset intervention (one regression with two explanatory variables)

\begin{tabular}{|c|c|c|c|}
\hline & Coefficient & Significance: $\mathrm{P}>|\mathrm{z}|$ & Standard Error \\
\hline guarantees & 0.0244 & 0.743 & 0.074 \\
\hline capital injections & 0.56 & 0.302 & 0.542 \\
\hline \multicolumn{4}{|c|}{$\begin{array}{l}\text { conditional variables for liabilities intervention } \\
\text { (one regression with two explanatory variables) }\end{array}$} \\
\hline & Coefficient & Significance: $P>|z|$ & Standard Error \\
\hline asset purchases & 0.107 & 0.598 & 0.203 \\
\hline capital injections & 0.581 & 0.250 & 0.505 \\
\hline \multicolumn{4}{|c|}{$\begin{array}{l}\text { conditional variables for equity intervention } \\
\text { (one regression with two explanatory variables) }\end{array}$} \\
\hline & Coefficient & Significance: $\mathrm{P}>|\mathrm{z}|$ & Standard Error \\
\hline asset purchases & -0.118 & 0.626 & 0.243 \\
\hline guarantees & $0.242 *$ & 0.128 & 0.159 \\
\hline
\end{tabular}

Appendix 6-D / Figure 1: Log odds for significant variables

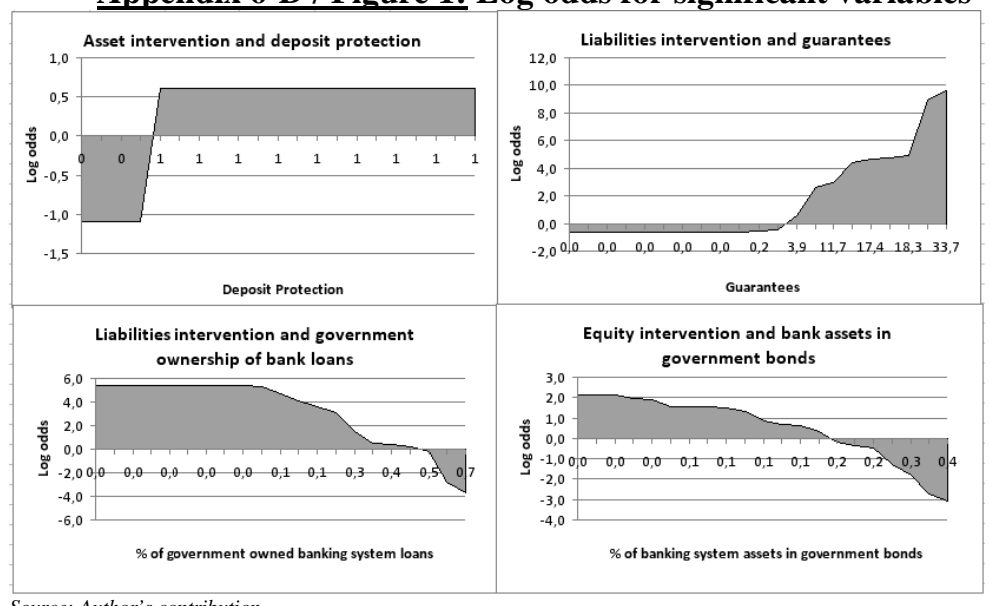

Source: Author's contribution. 


\section{Nederlandse Samenvatting}

Dit proefschrift beschrijft twee manieren waarop de overheid financiële risico's loopt: middels garanties die onderdeel zijn van een publiek-private samenwerking, en als gevolg van interventies tijdens de financiële crisis.

De belangrijkste vraag die in het proefschrift wordt gesteld is onder welke voorwaarden overheden tot publiekprivate samenwerking (PPS) over kunnen gaan, rekening houdend met het correct prijzen van risico's van die samenwerking, het effect van de samenwerking op de nationale rekeningen en de gevolgen van overheidsgaranties die uit de samenwerking voortvloeien. Uit de analyse in het proefschrift blijkt dat PPS-en vooral op publieke investeringen lijken, en vaak resulteren in expliciete, maar voorwaardelijke verplichtingen (vergelijkbaar met overheidsschuld, maar afhankelijk van de resultaten die met de PPS worden geboekt). Met behulp van een scenario analyse kan de waarde van de uit een PPS voortvloeiende, voorwaardelijke kasstromen worden bepaald, alsmede het effect van die kasstromen op investeringsbeslissingen.

In het eerste scenario dat onderzocht wordt, worden alle PPS projecten gefinancierd alsof er sprake is van een typische overheidsinvestering. Er is dan sprake van een direct effect voor de kapitaalrekening van de overheid, aangezien de initiële investeringskosten meegenomen dienen te worden bij het bereken van de schuldquote van een land. Dit effect kan echter verminderd worden door positieve kasstromen die voortkomen uit het uitbaten van de investering (denk bijvoorbeeld aan tolgelden). In het tweede scenario is sprake van een typische PPS. De garanties die daarbij gebruikt werden, resulteren in negatieve kasstromen, die de kans op faillissement van een land vergroten aangezien de schuldquote toeneemt. Een investeerder in overheidsobligaties dient dan ook niet alleen naar de traditionele, beperkte definitie van overheidsschuld te kijken, maar zou tevens de voorwaardelijke kasstromen die uit PPS projecten voort kunnen komen mee moeten nemen bij het beoordelen van de schuldenpositie van een land. 
In het derde en vierde scenario word veronderstelt dat de overheid de mate waarin zij risico's loopt door de garantstellingen in een PPS kan verkleinen, door het kopen van een credit default swap (CDS), als verzekering tegen de kans op faillissement van de private partner. Hierdoor ontstaan, naast de gebruikelijke kasstromen bij een PPS, twee additionele kasstromen: een als betaling naar degene die de CDS verkoopt, en een voorwaardelijke kasstroom als uitbetaling van de CDS door de verkoper, als de private partner failliet gaat. Vervolgens kan, in het derde scenario, de zogeheten 'mid-market' spreiding tussen aankoop- en verkoopprijs voor de CDS berekend worden. Aangezien er ook voor de overheid zelf een faillissementsrisico bestaat, kan deze CDS spreiding ook berekend worden rekening houdende met dit risico, in het vierde scenario. In beide gevallen kan de prijs berekend worden die door de gemeenschap betaald wordt voor de PPS.

De recente financiële crisis, die in 2007 begon, spreidde zich al snel door het financiële systeem, als gevolg van een serieuze liquiditeitsproblemen en solvabiliteitsproblemen. Overheden reageerden elk op hun eigen, specifieke manier op de verslechterde situatie in het financiële systeem. Veel van de overheidsingrepen in het financiële systeem vertonen kenmerken van een PPS. Met behulp van de methodes die in de eerste helft van dit proefschrift ontwikkeld zijn, kunnen we dan ook de impact van de beleidsmaatregelen die zijn genomen tijdens de crisis evalueren. Specifiek kunnen we kijken naar: a) het effect van een PPS op de balans situatie van een bank, b) de belangrijkste factoren die de keuze voor overheidsingrijpen bepaalden, en c) de meest efficiënte combinatie van interventies, ten einde de impact op overheidsschuld en overheidstekort zo beperkt mogelijk te houden.

In het tweede deel van het proefschrift wordt ieder van deze elementen behandeld. Belangrijkste instrument hierbij is een vereenvoudigde weergave van de balans van zowel de overheid als de banken. Met behulp van deze balansen kunnen 
interventies gecategoriseerd worden als 'activa', 'passsiva' of 'eigen vermogen' interventies.

De ex post resultaten laten zien dat 'activa' interventies tot een significante toename van schuldenrisico voor de overheid kan leiden, aangezien de overheid activa op haar balans neemt, die op dat moment niet goed gewaardeerd kunnen worden. Het moeilijkste onderdeel van de waardering van deze activa is het effect van macro-economische schokken. Op de balans van de bank, leidt dezelfde interventie tot een herstructurering van de activa zijde van de balans, waardoor de liquiditeit en 'gezondheid' van de bank balans verbetert.

Garanties door de overheid leiden per definitie niet (direct) tot veranderingen voor de activa zijde van de bank balans. Garanties zijn dan ook de meest neutrale methode voor de overheid om te interveniëren, vanuit het oogpunt van de houdbaarheid van de schuldpositie van de overheid. Echter, de verwachte waarde van garanties kan berekend worden, waardoor de impact van garanties op de balans wel degelijk berekend kan worden. Voor de bank vormen de garanties een voorwaardelijk deel van de activa zijde van de balans, terwijl we verwachten dat de passiva zijde van de balans van de overheid voor eenzelfde hoeveelheid belast wordt.

'Eigen vermogen' interventies verlengen de balans van een bank. Hierdoor dreigt het risico dat de solvabiliteit van de bank (enigszins) overschat wordt. Ontegenzeggelijk heeft deze vorm van interventie de meeste impact. Uit de analyse blijkt dan ook dat het aanbeveling verdient om deze vorm van interventie het beste gecombineerd kan worden met activa interventies, teneinde zo de verhoudingen tussen de activa en passiva zijde van de balans zo min mogelijk te verstoren. Anders gezegd beïnvloeden beleidsmakers hiermee wel korte termijn liquiditeitsproblemen, terwijl ze de solvabiliteit van de bank ongemoeid laten. Hierbij dient wel opgemerkt te worden, dat de uiteindelijke effectiviteit van een crisis maatregel sterk afhangt van de eigen vermogenspositie van een bank voordat de interventie plaatsvindt. 
Tot slot analyseert het proefschrift ex ante het interventie proces van overheden, met een empirische analyse. Uit deze analyse komt allereerst naar voren dat de kans op een (additionele) interventie maatregel zeer sterk toeneemt wanneer reeds voor een andere interventie maatregel is gekozen. Ten tweede blijkt dat de aanwezigheid van een deposito garantie systeem en additionele verzekeringsconstructies voor passiva in sterke mate de keuze voor een 'activa' interventie bepalen. Ten derde blijkt dat 'passiva' interventies meestal uitgesloten zijn, nadat reeds garanties voor leningen zijn verstrekt. Ten vierde blijkt dat wanneer intensief is geïntervenieerd aan de passiva dan wel aan de activa zijde, het zeer waarschijnlijk is dat vervolgens ook een deelneming aan het eigen vermogen plaatsvindt.

Samenvattend blijkt dat, zelfs wanneer overheden zelf ernstig beperkt werden in hun acties, overheidsgaranties effectief zijn ingezet tijdens de crisis. Dit type garanties is een essentiële maatregel gebleken om vertrouwen ter herstellen, terwijl tegelijkertijd de maximale schuldenrisico's voor de gemeenschap bekend zijn. 


\section{Curriculum Vitae \\ Manos Sfakianakis}

Manos was born (1977) and grew up in Heraklion, Crete, Greece. He received his bachelor's degree in Economics at the National and Kapodistrian University of Athens, school of law, economics and political sciences, department of economics (1999). He continued his studies at Brunel University, department of economics and finance, where he obtained his Master's degree in International Money, Finance and Investment (2001).

Manos currently works at the General Secretariat for Research and Technology in Greece (Foundation for Research and Technology - Hellas) as a financial executive. He is also a faculty member in the Technological Educational Institute (TEI) of Crete teaching various courses, such as Financial Management, Macroeconomics, Microeconomics, Money and Banking and Financial Markets. $\mathrm{He}$ is also supervising bachelor's and master's degree theses. He concurrently works in other educational instructions as well (Southern New Hampshire University - U.S.A., Nottingham Trent University - U.K., Public Institute for Vocational Training) teaching similar modules. Apart from that, he is an active member of the economics chamber of eastern Crete (since 1999), an elected member of the national board of quasi-public research institutions (since 2008) and an elected representative in the national labors' union (since 2008).

Manos started his PhD, in March 2007, with the first cohort of the Governance and Policy Analysis Dual Career Program (GPAC $\left.{ }^{2}\right)$, Maastricht Graduate School of Governance, Maastricht University. His research deals with public-private partnerships with a main focus on contingent obligations that arise from such partnerships. He is interested in two views of these contingencies: a) public guarantees as a main element of PPPs and their effect on the national accounts and b) public guarantees as a government intervention during banking crises. 


\section{Maastricht Graduate School of Governance Dissertation Series}

Henry Espinoza Peña

Impact Evaluation of a Job-Training Programme for

Disadvantaged Youths: The Case of Projoven

MGSoG Dissertation Series, nr 16 (2011)

Florian Tomini

Between Family and Friends

Understanding the Interdependency of Private Transfers

MGSoG Dissertation Series, nr 15 (2010)

Michal Polakowski

The Institutional Transformation of Social Policy in East

Central Europe: Poland and Hungary in comparative and

historical perspective

MGSOG Dissertation Series, nr.14 (2010)

Maha Ahmed

Defining, measuring and Addressing Vulnerability

The Case of Post Conflict Environments

MGSOG Dissertation Series, nr.13 (2010)

Pascal Beckers

Local space and economic success: The role of spatial segregation of migrants in the Netherlands

MGSOG Dissertation Series, nr. 12 (2011)

Victor Cebotari

Conflicting Demands in Ethnically Diverse Societies

Ethnopolitical Contention and Identity Values in Europe

MGSOG Dissertation Series, nr. 11 (2010) 
Dennis Gyllensporre

Competing and Complementary Perspectives on the EU as a Crisis Management Actor: An Examination of the Common Security and Defence Policy through the Lenses of Idealism and Realism

MGSOG Dissertation Series, nr. 10 (2010)

Judit Vall Castello

Business Cycle and Policy Effects on Labor Market Transitions of Older and Disabled Workers in Spain

MGSOG Dissertation Series, nr. 9 (2010)

Keetie Roelen

False Positive or Hidden Dimensions: the definition and measurement of child poverty

MGSOG Dissertation Series, nr. 8 (2010)

Denisa Sologon

Earnings Dynamics in Europe

MGSOG Dissertation Series, nr. 7 (2010)

Melissa Siegel

Money and Mobility: Migration and Remittances

MGSOG Dissertation Series, nr. 6 (2010)

Jessica Hagen-Zanker

Modest Expectations: Causes and effects of migration on migrant households in source countries

MGSOG Dissertation Series, nr. 5 (2010)

Mirtha Muniz Castillo

Human Development and Autonomy in Project Aid: Experienecs from four bilateral projects in Nicaragua and El Salvador

MGSOG Dissertation Series, nr. 4 (2009) 
Christiane Arndt

Governance Indicators

MGSOG Dissertation Series, nr. 3 (2009)

Britta Augsburg

Microfinance - Greater Good or Lesser Evil?

MGSOG Dissertation Series, nr. 2 (2009)

Geranda Notten

Measuring and Managing Poverty Risks

MGSOG Dissertation Series, nr. 1 (2008) 